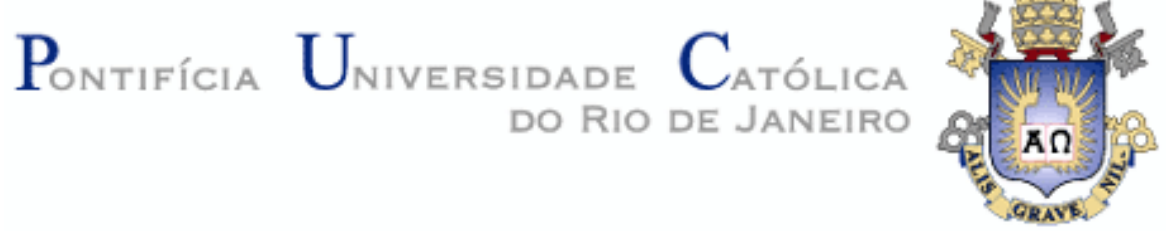

Tatiane Marques de Oliveira Martins

O lúdico como constituinte do fazer escolar: uma experiência no ensino de Língua Portuguesa

Tese de Doutorado

Tese apresentada como requisito parcial para obtenção do grau de Doutor pelo Programa de Pós-graduação em Educação do Departamento de Educação do Centro de Teologia e Ciências Humanas da PUC-Rio.

Orientadora: Prof $\stackrel{a}{\text { a }}$ Maria Apparecida Campos Mamede Neves 


\title{
O lúdico como constituinte do fazer escolar: uma experiência no ensino de Língua Portuguesa
}

\begin{abstract}
Tese apresentada como requisito parcial para obtenção do grau de Doutor pelo Programa de Pós-graduação em Educação do Departamento de Educação do Centro de Teologia e Ciências Humanas da PUC-Rio. Aprovada pela Comissão Examinadora abaixo assinada.
\end{abstract}

\author{
Prof?. Maria Apparecida Campos Mamede Neves \\ Orientadora \\ Departamento de Educação - PUC-Rio \\ Prof?. Maria Inês Galvão Flores Marcondes de Souza \\ Departamento de Educação - PUC-Rio \\ Profa. Rita Maria de Souza Couto \\ Departamento de Educação -PUC-Rio

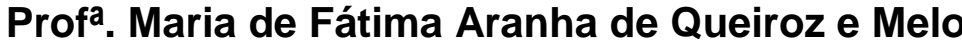 \\ Universidade Federal de São João del-Rei - UFSJ \\ Prof. Lino de Macedo \\ Universidade de São Paulo - USP \\ Profa. Denise Berruezo Portinari \\ Coordenadora Setorial do Centro de Teologia e Ciências Humanas \\ PUC-Rio
}

Rio de Janeiro, 04 de abril de 2016. 
Todos os direitos reservados. É proibida a reprodução total ou parcial do trabalho sem autorização do autor, do orientador e da universidade.

\section{Tatiane Marques de Oliveira Martins}

Graduou-se em Letras: Português-Literaturas, em 1996, pela Universidade do Estado do Rio de Janeiro (UERJ). Pósgraduou-se em Psicopedagogia pela Universidade Federal do Rio de Janeiro (UFRJ), em 1999. Obteve o título Especialista em Língua Portuguesa, pela Universidade do Estado do Rio de Janeiro (UERJ), em 2006. Tornou-se Mestre em Educação pela Pontifícia Universidade Católica do Rio de Janeiro (PUC-Rio) em 2011. Tem experiência docente em instituições particulares e públicas de Educação Básica e Ensino Superior. Hoje, sua principal função é de professora de Língua Portuguesa do Colégio Militar do Rio de Janeiro em regime de Dedicação Exclusiva (concurso de 1998). Suas áreas de interesse, nas quais vem desenvolvendo pesquisas e reflexões, são: Ensino de Língua Portuguesa com práticas inovadoras, uso das mídias digitais, gamificação e lúdico.

Ficha Catalográfica

\footnotetext{
Martins, Tatiane Marques de Oliveira

O lúdico como constituinte do fazer escolar: uma experiência no ensino de língua portuguesa / Tatiane Marques de Oliveira Martins ; orientadora: Maria Apparecida C. Mamede Neves. - 2016.

236 f. : il. color. ; $30 \mathrm{~cm}$

Tese (doutorado)-Pontifícia Universidade Católica do Rio de Janeiro, Departamento de Educação, 2016.

Inclui bibliografia

1. Educação - Teses. 2. Lúdico. 3. Língua Portuguesa. 4. Pesquisa-ação. 5. Autoestudo. I. Neves, Maria Apparecida Campos Mamede. II. Pontifícia Universidade Católica do Rio de Janeiro. Departamento de Educação. III.Título.
} 
A João, companheiro inseparável, Luiza e Gustavo, frutos desse amor, a meus pais e a minha sogra, que em tudo me incentivam, à Cida, que tanto me ensina, me anima e me conforta, à tia Laurinda, que sempre foi um exemplo de profissional para mim, a todos os meus familiares de sangue e de coração (os amigos do peito, antigos ou mais recentes!), que sempre acreditam em mim e muitome apoiam, e a meus alunos, pois, sem eles, não seria a profissional que sou hoje. 


\section{Agradecimentos}

Muitos agradecimentos? Não, para quem acredita que o conhecimento se constrói em rede e ser grato na vida é transformador. O que sou, o que sei e os caminhos que percorro provêm das minhas interações com meus familiares, amigos, professores, colegas e alunos. Portanto, serei sempre imensamente grata...

A Deus que, mesmo quando ando de vendas nos olhos e tampões em meus ouvidos, não me abandona e me conduz pelos caminhos que devo seguir.

Ao meu marido que em tudo, há 25 anos, me apoia, e com quem dialogo sobre Educação, Política, Economia, Saúde, Religião, Vida. Somos um, sendo dois. Somos um nesse amor longo, eterno, gostoso, inteiro. Obrigada por estar sempre ao meu lado.

Ao meu filho e à minha filha, que cresceram me vendo estudar, batalhar, trabalhar, dia a dia, com muita paixão, mas também com muito estresse pelas inúmeras demandas da vida. Obrigada por entenderem a importância do que faço para mim e para vocês. Obrigada por estarem seguindo seus caminhos estudando e investindo muito em sua própria formação. Isso só me faz ter a certeza de que estamos no caminho certo.

Ao meu pai e à minha mãe, por terem me gerado, me amado, por serem quem são em minha vida, por acreditarem na minha capacidade e me incentivarem sempre. Amo vocês!

À minha adorável e incansável orientadora, Apparecida Mamede, que, de braços abertos, com muita afetividade e conhecimento, soube me conduzir ludicamente por diversas aprendizagens e sempre me leu, por dentro e por fora, traduzindo o que penso/escrevo e me traduzindo como pessoa por seus olhos doces e amorosos. Conviver com você, Cida, é um privilégio imensurável. Obrigada por tudo! Obrigada a você e ao doce e querido Mamede!

Ao CMRJ, onde trabalho há 18 anos completos neste mês de abril, por ter autorizado o desenvolvimento de minha pesquisa nas turmas em que lecionava.

Às professorasMaria Inês e Rita Couto, pelas incansáveis leituras de meu trabalho na Qualificação I, ainda tão incipiente, e Qualificação II, quando elevaram minha autoestima.

A todos os professores da banca, por sua disponibilidade em ler minha pesquisa e contribuir com críticas e sugestões para meu aperfeiçoamento, mas não posso deixar de agradecer em especial a Lino de Macedo que, mesmo sem conhecê-lo pessoalmente (só terei esse prazer na hora da defesa), sempre esteve presente em minhas reflexões como professora.

A cada membro do nosso eterno grupo de pesquisa Jovens em Rede, em especial nesse momento, à Stella Pedrosa, minha "amiga-crítica", que se dispôs a ir ao 
CMRJ assistir a várias aulas em que eu colocava em prática a estratégia relatada nesta pesquisa.

Aos colegas deDoutorado(turma de 2012 e agregados), com quem convivi nos dois primeiros anos, enquanto cumpríamos os créditos, em especial Fátima Lima e Tânia Jardim.

A todos os professores que conheci durante o curso e com quem tive o prazer de aprender ainda mais. Em especial, às professoras Zaia Brandão, ser humano incrível, e Lynn Alves, que me recebeu tão bem em Salvador.

Ao escritor Felipe Castilho que, mesmo sem saber, muito me ajudou no desenvolvimento da estratégia que propus e desenvolvi nesta pesquisa, com os livros de sua autoria adotados no $6^{\circ}$ ano.

Ao meu primo Lúcio Álvaro, meu "motoboy" eterno, à tia Dina e toda aquela maravilhosa família, à tia Zeca e tio Tinoco e aos meus padrinhos Jamile e Orlando e meu primo Fred, por terem me recebido, me acolhido, me apoiado, durante tantas idas a Salvador, enquanto fazia uma matéria do Doutorado com a professora Lynn Alves.

Ao meu eterno amigo Cláudio Capuano, que foi quem praticamente me obrigou a fazer o concurso do CMRJ e depois vivia dizendo que eu tinha de fazer Mestrado e Doutorado. Ele se foi repentinamente no meio desse processo todo, mas suas palavras ainda ecoam em meus ouvidos e sua amizade será para todo sempre.

Às minhas amigas "As melhores", aos "Meninos e Meninas" e outros queridos colegas-amigos, que fazem do meu dia a dia no trabalho algo tão prazeroso e especial. Seria bem difícil sobreviver às inúmeras demandas (tantas vezes surreais) sem vocês ao meu lado. Sou profundamente feliz por trabalhar com vocês!

Aos meus velhos e eternos amigos de uma vida inteira, que tanto me ensinam e que tanta paciência têm comigo. Vocês são especiais!

Aos meus amigos virtuais, sejam eles também presenciais ou não, que curtem as minhas conquistas publicadas nas redes sociais, partilham das minhas alegrias e me dão força constantemente, com palavras amigas, de força e de ânimo. O carinho dos que se fazem presentes é sempre muito bom.

Enfim...

Aos meus alunos, de ontem, de hoje e, também, os de amanhã, em especial aos que participaram desta pesquisa. Todos vocês sempre me inspiram/inspiraram a não me curvar às limitações do espaço físico da sala de aula nem às pedras que encontramos no caminho. Sem nossas interações nesses meus vinte anos de prática docente, sem as suas inquietações que se tornam/tornaram minhas inquietações, principalmente pelo afeto e confiança construída, eu realmente não seria a pessoa e a profissional que sou hoje. Muito obrigada! 


\section{Resumo}

Martins, Tatiane Marques de Oliveira; Mamede-Neves, Maria Apparecida Campos. O lúdico como constituinte do fazer escolar: uma experiência no ensino de Língua Portuguesa. Rio de Janeiro, 2016. 236p. Tese de Doutorado - Departamento de Educação, Pontifícia Universidade Católica do Rio de Janeiro.

A presente tese teve como ponto de partida a evidência de que, cada vez mais, se queremos uma escola para todos, precisamos promover a inserção do aluno numa nova estratégia de ensino que dê conta das mudanças na sociedade decorrentes da cultura do digital e das demandas dos alunos que nela se inserem. Assim sendo, o trabalho investigativo exposto objetivou discutir o fazer escolar na interação docente-discente a partir de estratégias que apresentavam condições lúdicas que, por suas características estruturais, ressignificavam o processo de ensino-aprendizagem e davam maior significação à construção do conhecimento. O referencial que permeou a construção teórica desta pesquisa e iluminou a experiência nas reflexões e aprendizagens se construiu segundo os conceitos de jogo e lúdico. O conceito de jogo proveio de Huizinga e Piaget; a relação entre jogo/lúdico e Educação foi discutida tendo em vista as considerações de Piaget, Winnicott, Paín e Macedo, Petty e Passos. Adotou-se o desenho metodológico de pesquisa-ação, com ênfase no caráter avaliativo de um programa inovador. Como a estrutura metodológica da pesquisa pressupunha também uma permanente avaliação da professora condutora do processo, apresentou ainda um caráter de autoestudo. Os autores foram 54 adolescentes, alunos do sexto ano do Ensino Fundamental do Colégio Militar do Rio de Janeiro na disciplina Língua Portuguesa durante todo o segundo semestre letivo de 2014. Os dados foram extraídos através de diferentes meios de coleta: diário de bordo da professorapesquisadora; vídeos que captaram momentos das aulas; produções dos autores, com destaque para os dizeres dos discentes em questionário de perfil de estudo, em caderno de opinião alimentado durante todo o processo e em três autoavaliações. A análise dos resultados permitiu identificar representações dos discentes sobre questões comuns à vivência escolar como, por exemplo, as avaliações e a visão que revelam sobre as práticas a que são submetidos pelos professores no cotidiano da sala de aula. Também foi possível analisar 
criticamente as construções coletivas de aprendizagem, singularidades e individualidades nos processos de ranqueamento e consequente menos-valia daquele aluno que não atinge os objetivos intelectivos, formais de base avaliativa escrita. Os resultados mais expressivos desta pesquisa indicam que: ocorreu mudança de atitude do aluno, com aumento na participação, no envolvimento e progresso na aprendizagem formal da disciplina Língua Portuguesa, quando submetido a uma estratégia lúdica de aprendizagem, na qual a ele é dada a chance de autoria; a relação professor/aluno com as práticas lúdicas ultrapassou expressivamente o espaço de aprendizagem intelectiva para a integração do desenvolvimento afetivo em um processo de confiança construída entre ambos com feedback constante e interativo; algumas representações construídas revelaram o medo, o tédio e o "branco" como queixas comuns da vivência escolar tradicional por parte dos alunos. Finalmente, o trabalho ratifica a necessidade de ampla reflexão sobre: o fazer escolar, as práticas docentes, as condições físicas, sociais e afetivas de aprendizagem dos discentes e as condições de trabalho do professor. Entretanto, abre também uma perspectiva de mudança pedagógica a curto prazo se adotados procedimentos em que o gozo por aprender seja a tônica.

\section{Palavras-chave}

Lúdico; Língua Portuguesa; pesquisa-ação, Autoestudo. 


\section{Abstract}

Martins, Tatiane Marques de Oliveira; Mamede-Neves, Maria Apparecida Campos (Advisor).The ludic as a part of the school environment: an experience in the Portuguese Language teaching. Rio de Janeiro, 2016. 236p. $\mathrm{PhD}$ Thesis. Departamento de Educação, Pontifícia Universidade Católica do Rio de Janeiro.

The present thesis was driven by the evidence that, even more frequently, if we want a school for all, we need to insert students within a new teaching strategy, one that covers the society's changes deriving from digital culture and from the demands of the students that are immersed in it. Therefore, the investigation work herein exposed aimed to discuss the school practices in the interaction teacher-learner, based on the strategies presented in ludic conditions, which, due to their structural features, gave new meaning to the teaching-learning process and provided new meaning to the construction of knowledge. The references embedded in the theoretical construction of this research and which enlightened our reflections and learning process were built on the concepts of games and ludic activities. The concept of games originated from Huizinga and Piaget; the relation between games/ludic activities and Education was discussed observing Piaget's, Winnicott's, Pain's and Macedo, Petty \& Passos' considerations. We adopted the methodology design of research-in-action, emphasizing the evaluation character of an innovative program. As the methodology structure of the research presumed a continuous evaluation of the teacher who conducted the process, it also presented a self study character. Fiftyfour teenage students of Portuguese language, from the sixth grade of Colegio Militar do Rio de Janeiro, were the actors during the whole second semester of 2014 school year. The data were extracted via different collection means: the teacher-researcher journal; videos that captured classroom moments; learners' production, with a highlight to their statements on a study profile questionnaire, registered in an opinion notebook filled out during the whole process within three self evaluations. The analysis of the results allowed the identification of the learners' representations about common issues regarding school life, such as: the evaluation and their point of view on practices they are submitted to in the classroom everyday life. It was also possible to critically analyze collective 
knowledge construction, singularities and individualities in the ranking processes and, consequently, the feeling of loss from those who do not reach the formal cognitive goals in a written basis evaluation. The most expressive results of such research indicated: a) that an attitude change from the learner has occurred, increasing participation,engagement and progress in the formal process of learning Portuguese language whenever the learner was submitted to a ludic learning strategy in which he was given the chance of being the actor; b) the relation teacher/learner with ludic practices expressively exceeded the intellectual learning space towards integration of affective development in a trustful way, built along constant and interactive feedback.Also, some of the learner's documentated representations revealed fear, boredom and 'thoughts going blank' as the learners' mostcommon complaints of traditional school life. Finally, the paper confirms the need of a wide discussion about: school practice, teaching practice, learners' physical, social and affective conditions and teachers' working conditions. However, it also opens a perspective for pedagogical change in a short term, if procedures are adopted in a way that the delight of learning is the highlight.

\section{Keywords}

Ludic; Portuguese language; Research-in-action; Self-study. 


\section{Sumário}

1. Introdução: de onde vim e para onde estou indo 21

2. Ludus, Ludere 26

2.1. Eu jogo, tu jogas, ele joga... e assim o mundo gira. 29

2.2. Na verdade, o que importa: o jogo ou a fantasia do jogo 38

2.3. Uni duni tê: entre o jogo e o lúdico. 44

3. Metodologia 46

3.1. Ambiente da pesquisa: a instituição Colégio Militar do Rio de 48 Janeiro

3.2. O ano em que a pesquisa foi realizada: características 52 próprias

3.3. Sujeitos da pesquisa

53

3.4. Instrumentos 58

3.4.1. Instrumentos da pesquisa $\quad 59$

3.4.2. Instrumentos da ação inovadora 61

$\begin{array}{ll}\text { 3.5. Procedimentos } & 65\end{array}$

3.5.1. Procedimentos da Ação 67

4. A implantação da experiência: primeiro período da pesquisa 75 (3ํ. bimestre do ano letivo)

4.1. Conteúdo Parcial de Língua Portuguesa para o 6ํa ano do 75 Ensino Fundamental

4.1.1. Pré-missões lúdicas: o início de uma mudança 77

4.1.2. Missões lúdicas com enredo: o despertar da alegria 88

4.1.3. Missões lúdicas: a descoberta do que não se sabia 95

4.1.4. As relações na aprendizagem: uma percepção do todo 101 (parte 1)

5. A implantação da experiência: segundo período da pesquisa 105 
(4o bimestre do ano letivo)

5.1. Missões lúdicas: grandes descobertas 105

5.1.1. Missões culturais extracurriculares: e a escola sai da 124 escola

5.1.2. Atividades complementares

5.1.3. As relações na aprendizagem: uma percepção do todo (parte 2)

6. A culminância da experiência: discussão dos dados (parte 1)

6.1. O que a estratégia proporcionou de concreto na formação desses alunos?

6.2. Escrever; escrever e pensar; pensar e escrever: urge refletir sobre a competência para se expressar

\subsection{A busca por aprender a aprender estudar}

7. A culminância da experiência: discussão dos dados (parte 2)

7.1. Os alunos têm muito a dizer. Queremos ouvi-los?

7.1.1. Sobre construção da opinião: em busca da cidadania

7.1.2. Os alunos têm muito a dizer: a autoria em construção

7.1.3. Os alunos têm muito a dizer quando o espaço para autoria Ihes é dado

7.1.4. Os alunos têm muito a dizer: só "legal", nem pensar!

7.1.5. Os alunos têm muito a dizer: Cuidado! Cenas fortes para professores mais racionais

7.2. Trabalho em grupo: cria-se vínculo numa confiança desconfiada?

7.3. Do grupo à guilda: Sobre o clímax da proposta lúdica - uma estratégia na qual se pretendeu construir uma aprendizagem colaborativa

7.4. Dificuldades que aparecem nos pequenos detalhes: só 215 enxerga quem presta atenção

7.5. Finalmente, o lúdico realmente vale a pena? 
8. Lúdico que é lúdico marca para sempre nossas aprendizagens 220

9. Referências bibliográficas 226

10. Anexos 229

10.1. Permissão para o desenvolvimento da pesquisa no CMRJ 229

10.2. Questionário sobre as práticas de estudo dos alunos 230

10.3. Ficha autoavaliativa do 3 . bimestre 232

10.4. Ficha autoavaliativa do $4^{\circ}$. bimestre 233

10.5. Ficha autoavaliativa sobre a produção de teatro de 234 fantoches em grupo

10.6. Código para correção de redação 235

10.7. Trecho do livro Ouro, fogo e megabytes 236 


\section{Lista de Figuras}

Figura 1: Foto da sala de aula do CMRJ no início do século XX 50 publicada na capa da Revista Babilônia.

Figura 2: Esquema dos instrumentos de pesquisa e da ação 59 inovadora

Figura 3: Poema visual de AutorA12 80

Figura 4: Poema visual de AutorA3 80

Figura 5: Poema visual de AutorB15 81

Figura 6: Poema visual de AutorA46 81

Figura 7: Poema de AutorB54 82

Figura 8: Junção de uma Guilda 86

Figura 9: Base para o jogo Adedanha 87

Figura 10: Pesquisa feita no buscador "Google" sobre o maior 92 folclorista brasileiro.

Figura 11: Pesquisa feita no buscador "Google" sobre a lenda 93 brasileira mais rara.

Figura 12: Texto "Circuto fechado" de uma guilda da Turma A. 99

Figura 13: Texto "Circuto fechado" de uma guilda da Turma B. 99

Figura 14: HQ a partir de anedota produzida por uma guilda. 115

Figura 15: HQ a partir de anedota produzida por uma guilda. 116

Figura 16: HQ a partir de anedota produzida por uma guilda. 117

Figura 17: HQ a partir de anedota produzida por uma guilda. 118

Figura 18: Tira de $\mathrm{HQ}$ a partir de trecho do livro paradidático 120 produzida por uma guilda.

Figura 19: Tira de $\mathrm{HQ}$ a partir de trecho do livro paradidático produzida por uma guilda.

Figura 20: Tira de $\mathrm{HQ}$ a partir de trecho do livro paradidático produzida por uma guilda. 
Figura 21: Exemplo da atividade de Memória do Ano, AutorA35. 124

Figura 22: Opinião de aluno sobre filme "O garoto" - Missão 129 Cultural (grifo meu).

Figura 23: Texto 1 de 3 de AutorB38.

Figura 24: Texto 2 de 3 de AutorB38.

Figura 25: Texto 3 de 3 de AutorB38.

Figura 26: Texto 1 de 3 de AutorB20.

Figura 27: Texto 2 de 3 de AutorB20 (parte 1).

Figura 28: Texto 2 de 3 de AutorB20 (parte 2).

Figura 29: Texto 3 de 3 de AutorB20 (parte 1).

Figura 30: Texto 3 de 3 de AutorB20 (parte 2).

Figura 31: Texto 1 de 3 de AutorA10.

Figura 32: Texto 2 de 3 de AutorA10.

Figura 33: Texto 3 de 3 de AutorA10.

Figura 34: Texto 1 de 3 de AutorB14.

Figura 35: Texto 2 de 3 de AutorB14.

Figura 36: Texto 3 de 3 de AutorB14.

Figura 37: Texto 1 de 2 de AutorB34.

Figura 38: Texto 2 de 2 de AutorB34 (parte 1).

Figura 39: Texto 1 de 2 de AutorB34 (parte 2).

Figura 40: Texto 1 de 2 de AutorA39.

Figura 41: Texto 2 de 2 de AutorA39 (parte 1).

Figura 42: Texto 2 de 2 de AutorA39 (parte 2).

Figura 43: Letra do AutorB17, com problemas no traço pouco 162 definido e na construção textual fluente.

Figura 44: Letra do AutorB1, com problemas na plasticidade do 162 traço (ainda há certo tremor). 
Figura 45: Letra do AutorB34, com traços bem definidos e firmes. 163

Figura 46: Trabalho de memória do ano do AutorB17. 163

Figura 47: Poema visual produzido pelo aluno AutorB53 . 184

Figura 48: Poema visual produzido pelo aluno AutorA21 . 185

Figura 49: Comentários de alunos que não participavam da nova 187 estratégia no Portal Educandus.

Figura 50: Comentários de alunos que participavam da nova estratégia no Portal Educandus.

Figura 51: Comentários de alunos que participavam da nova estratégia no Portal Educandus.

Figura 52: Nuvem de palavras e expressões com os sentimentos 190 dos alunos em relação às provas. Relacionam-se tamanho de letra com a maior ou menor frequência de uso de termos diretos ou sinônimos.

Figura 53: Nuvem de expressões negativas que se destacam nas 204 falas dos alunos sobre a atuação dos colegas nas guildas. 


\section{Lista de Fotos}

Foto 1: Sala de aula padrão do $6^{\circ}$ ano do EF no CMRJ em 2015.

Foto 2: Sala de aula padrão do 6ำ ano do EF no CMRJ em 201551 com os alunos enfileirados e naturalmente separados para produção de suas atividades

Foto 3: Mochilas igualmente pretas de alunos do $6^{\circ}$ ano do EF 84

Foto 4: Apresentação do Teatro de Fantoches, alunos da turma 105 B.

Foto 5: Apresentação do Teatro de Fantoches, alunos da turma 106 A.

Foto 6: Roletas do Folclore de alguns alunos da Turma A.

Foto 7: Roletas do Folclore de alguns alunos da Turma A.

Foto 8: Roletas do Folclore de alguns alunos da Turma B. 


\section{Lista de Gráficos}

Gráfico 1: Sobre o ato e costume de estudar em casa. 54

Gráfico 2: Sobre a prática de fazer deveres de casa. 55

Gráfico 3: Sobre o hábito de ler. 56

Gráfico 4: Percepção do aluno quanto à sua produção escrita. $\quad 57$

Gráfico 5: Sobre as impressões dos alunos com relação às 58 produções textuais.

Gráfico 6: Apresentação do quantitativo de alunos que realizaram cada Missão Cultural.

Gráfico 7: apresentação da participação ou não dos alunos nas 128 Missões Culturais 


\section{Lista de Quadros}

Quadro 1: Panorama geral das atividades propostas (terceiro

bimestre do ano letivo de 2014, primeiro período da pesquisa

Quadro 2: Panorama geral das atividades propostas (quarto

64 bimestre do ano letivo de 2014, segundo período da pesquisa).

Quadro 3: Código para representar a evolução qualitativa de cada aluno.

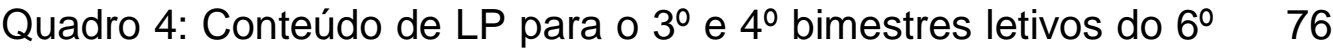
ano do EF

Quadro 5: Panorama geral das pré-missões lúdicas com quadro 78 explicativo.

Quadro 6: Panorama Geral das missões lúdicas com enredo, 90 com quadro explicativo.

Quadro 7: Panorama geral das missões lúdicas do terceiro 96 bimestre, com quadro explicativo.

Quadro 8: Inter-relações dos conteúdos de LP por meio de 102 variadas práticas nas Pré-Missões Lúdicas.

Quadro 9: Inter-relações dos conteúdos de LP por meio de 103 variadas práticas nas Missões Lúdicas (com e sem enredo).

Quadro 10: Panorama geral das missões lúdicas do quarto 107 bimestre - Parte I, com quadro explicativo.

Quadro 11: Panorama geral das missões lúdicas do quarto 108 bimestre - Parte II, com quadro explicativo.

Quadro 12: Panorama geral das missões culturais, com quadro explicativo.

Quadro 13: Panorama geral das atividades complementares, 134 com quadro explicativo.

Quadro 14: Inter-relações dos conteúdos de LP por meio de 137 variadas práticas.

Quadro 15: Código para representar a evolução qualitativa de cada aluno.

Quadro 16: Quantitativo de alunos em cada categoria 
Brincar e estudar

Enquanto um brinca O outro estuda

Brincar ou estudar

Brincar ou estudar

Eles não são antônimos

Porém, bem diferentes

Rimam e rimam

Quanto mais rimam

Mais perto eles ficam

(AutorA42) 


\section{Introdução: de onde vim e para onde estou indo}

A sala de aula sempre foi um grande desafio. Já faz tempo, no entanto, que as crianças e os jovens ganharam voz e, embora a escola ainda estejaaquém no tempo em relação às demandas de seus alunos, eles a transformam.Cobram mudanças ainda mais desafiadoras, principalmente devido à "metamorfose" que estamos sofrendo nos últimos anos com o advento da cultura do digital.

Encarar diariamente essa "garotada" sedenta por uma vida interessante e, muitas vezes, frenética nesse mundo líquido em que nos encontramos, exige do professor disposição e dinamismo constantes para entreter e cativar um público exigente, mas que também se dispersa com muita rapidez. Por sua vez, estar em atividade, há vinte anos, como professora de Língua Portuguesa, já me permitiu aprender e comparar, criticamente, muitas coisas. O aluno dos últimos dez anos difere ainda mais dos estudantes que antecedem a existência das redes sociais e, nos últimos anos, das mídias de comunicação imediata como Whatsapp. Por isso acredito que estar na sala de aula em um momento histórico de transformações reais, intensas e tão velozes como o que estamos vivendo é, além de grande desafio, um privilégio. Principalmente aos que se abrem a essas transformações e que se permitem refletir, sem preconceitos, sobre elas. Estes concedem a si mesmos, no mínimo, beber da água mais pura das mudanças: aquela que vem naturalmente com o frescor da juventude.

Tendo passado por instituições que atendem a públicos distintos e com propostas didático-pedagógicas, de certo modo, também distintas, comecei a entender melhor a importância de meu papel, de minha atuação, na vida daqueles com quem tenho o privilégio de conviver durante um ano letivo. Faz tempo essa percepção me leva a buscar me renovar sempre e a não me deixar acomodar. $\mathrm{O}$ engessamento e a reprodução quase mecânica da atuação parecem bastante naturais de acontecer com o professor que, mesmo estando em um grupo de trabalho, sente-se, muitas vezes, sozinho e isolado em sua jornada.

Acredito que os governantes, diretores de escolas, pesquisadores da Educação, críticos, jornalistas e a sociedade, em geral, precisam apoiar e valorizar seus professores. A (baixa ou alta) autoestima do docente reflete diretamente na vida de crianças e adolescentes que passam por nossas mãos todo ano. 
O que temos de concreto é que o mundo mudou. O quadro de giz e a aula quase que totalmente monológica não se adequam mais a um mundo plugado na internet em processo interativo a um toque dos dedos. Digo isso com muita tranquilidade com a experiência de quem passou por algumas etapas de experimentação, observação e vivência dessas mudanças, acreditando, inicialmente, que a escola poderia ser renovada simplesmente por meio da entrada das mídias digitais. Foi nesse sentido que desenvolvi minha pesquisa de Mestrado na qual investiguei o trabalho de professores blogueiros que procuravam reformular suas práticas em sala de aula através de seus conhecimentos e crenças em relação às possibilidades dos usos das mídias digitais, principalmente da Internet.

Essa busca que iniciei mais concretamente com o Mestrado se estendeu como norte de minha proposta inicial de Doutorado. Logo no início, porém, com uma diferença de menos de dois anos de minha defesa, comecei a entender o que já estava sendo apontado pelos professores que haviam participado de minha pesquisa: os estudantes resistiam a participar de atividades on-line proporcionadas por seus professores. Em outras palavras: descobri que havia um estranhamento entre o jovem usuário das mídias digitais em sua vida pessoal e o jovem discente, e esse desencontro não permitiria atingir meu objetivo de uma sala de aula mais interessante.

Um pouco frustrada com isso e, ao mesmo tempo, querendo entender em que estava errando foi que comecei a ver que a mudança não era a partir das ferramentas utilizadas e no domínio técnico de tais ferramentas e seus aplicativos. Isto é, trocar o caderno pelo tablet, o quadro de giz pelo data-show, o dever de casa no livro pelo fórum on-line não mudava muita coisa do formato obrigatório e tradicional da sala de aula e do processo de ensino e aprendizagem, embora, dependendo da dinâmica, já apontasse algumas boas tentativas de maior interação. A transformação tinha de ir muito além da tecnologia, tinha de atingir o que as mídias digitais traziam consigo: um novo modo de ver e pensar o mundo em que vivemos. Isto é, percebi que precisava buscar uma real mudança de paradigma: uma desconstrução do modo de aprender tradicional da escola.

Assim, voltei o meu olhar inicialmente para o entretenimento que se concretizava nas mãos das crianças e jovens: o jogo, no meu olhar inicial, o 
videogame. Quem joga - sejam os jogos tradicionais (em tabuleiros, de cartas etc.) em base analógica ou digital sejam os jogos de videogame - entende logo de início o que os jogos dispõem em sua estrutura; e essa estrutura gera em quem os joga uma demanda por saber, desvendar, perguntar, querer, assimilar, dominar, experimentar mais e mais as possibilidades, dimensões e as habilidades necessárias para explorar tal mundo. E é isso que a internet também vem permitindo. Ouso dizer que os jogos - não somente, mas, talvez, principalmente os que estão disponíveis hoje por meio das tecnologias digitais e que contêm grandes narrativas e conteúdos de diversas áreas do conhecimento - são verdadeiros sistemas de aprendizagem. Eles promovem grande diversidade de oportunidades de construção do conhecimento por quem os joga. Tomei conhecimento, então, em minhas buscas, de uma estratégia nova a que deram o nome de gamificação, mas ela acabou sendo apenas a porta de entrada para uma nova descoberta...

Tendo o lúdico como mote de minha pesquisa, tracei como objetivo saber se os estudantes mudam sua atitude diante da aprendizagem, isto é, se eles se tornam proativos por meio de estratégias lúdicas de ensino e se essa mudança promove um maior envolvimento em pontos importantes da disciplina Língua Portuguesa: leitura de mais livros e maior e melhor produção de textos. Para tanto, em resumo, como objetivos específicos, considerei importante observar, registrar e analisar que comportamentos concomitantes são desenvolvidos pelos autores no desempenho das tarefas propostas ao longo das atividades lúdicas de conteúdos escolares. Além disso, seria necessário verificar se as atividades lúdicas promovem uma mudança de comportamento dos alunos no aspecto da busca pelo conhecimento e da cooperação e colaboração da aprendizagem dos colegas de mesmo grupo; se um trabalho sistemático por meio de uma estratégia lúdica desencadeia o processo de equilibração responsável pela estruturação cognitiva; se o uso de tecnologia digital em algumas atividades potencializa o interesse dos estudantes e promove uma complementação à estratégia lúdica; se o lúdico permanente, a competição saudável e o feedback interativo e imediato promovem maior imersão do aluno no processo de aprendizagem; enfim, se os envolvidos nesse tipo de atividade apresentam uma melhora na compreensão da disciplina e na produção textual. 
Tinha como meta de minha pesquisa verificar se o uso de atividades lúdicas potencializa a aprendizagem específica, curricular, a partir da mudança de visão dos estudantes a respeito do que é a escola e o que ela pode proporcionar às suas vidas. E foi assim que o trabalho começou...

No início de tudo, no entanto, eu não enxergava o aspecto lúdico do jogo como o elemento mais importante. Vi o jogo, e depois o que aprendi sobre a estratégia gamificação, como atividades ou situações lúdicas em sua essência. Mas hoje estou aqui, descobrindo que a escola que desconhece ou nega o Homo Ludens não pode vingar mais na realidade em que nos encontramos.

Minha pesquisa se desenvolveu fundamentalmente pelo meu olhar para o outro, para o ser humano que estava e está diariamente à minha frente, ao meu lado. É por esse olhar, com a dimensão afetiva em evidência, que hoje considero que o lúdico é a base para a minha proposta didática, é o alicerce para que se possa desvendar e promover o desenvolvimento do processo de ensino e aprendizagem, numa relação que não pode ter como foco apenas o professor nem somente o aluno, mas a conjunção de ambos numa construção colaborativa e interativa de ação e reação para uma outra ação, e assim sucessivamente. E, nessa relação enredada, novas histórias vão se formando e novos seres vão se constituindo.

Quero deixar claro que praticamente não usei em minha pesquisa - e não precisaria usar - recursos da tecnologia digital. O que trago, porém, se baseia na compreensão de que a criança que está hoje na sala de aula apresenta, além de uma vivência de mundo diversa, pelas suas origens, valores, constituições familiares entre outros, uma percepção de mundo de forma diferente justamente pelo acesso a essa cultura do digital. Ela age e pensa diferente. Ela tem expectativas também diferentes. Então a escola também tem de ser diferente. Foi com essa concepção que atuei e realizei esta pesquisa que agora apresento.

$$
* * * * *
$$

Esta tese se constroi em oito capítulos de conteúdo. Após esta introdução, no capítulo 2, exponho o conceito de jogo e a construção do conceito de lúdico que norteou meu trabalho. Traço também o meu caminhar desde a proposta inicial 
que deu origem a esta pesquisa até a descoberta do lúdico como ponto forte do processo. A metodologia da pesquisa assim como os instrumentos e procedimentos são apresentados no capítulo 3 .

Nos capítulos 4 e 5, discorro, em detalhes, sobre tudo o que realizei na empiria durante os dois períodos do segundo semestre de 2014 em que atuei como professora-pesquisadora em duas turmas do sexto ano do Ensino Fundamental e apresento, de forma comentada, os dados que recolhi para análise.

Nos capítulos 6 e 7, dialogando com as fontes apresentadas na fundamentação teórica, analiso e discuto diversos dados recolhidos. Foi necessário fazer um recorte e privilegiar apenas alguns temas para a discussão, diante da riqueza e da quantidade de material existente.

Por fim, no capítulo 8, apresento considerações sobre a pesquisa realizada com minhas percepções acerca de minha prática docente em escolas que se expressam como "escola para todos", expressão essa utilizada nesta tese no sentido de escola para todas as classes sociais, todas as realidades culturais, por ser, como afirma Macedo (2007, p. 43), “compulsória e obrigatória”. Não trato, em momento algum, das questões específicas de uma escola inclusiva, no que diz respeito aos portadores de necessidades especiais, embora a estratégia que promovi tenha abertura para a grande diversidade de público. Porque é nessa escola para todos que acredito que o realizado por mim nesta pesquisa pode se estender à prática de muitos colegas que estão nessa luta. 


\section{Ludus, Ludere}

Quando penso em jogo hoje e na interação da criança com o jogo, entendo que se constrói uma situação de ação e reação constantes, com um feedback imediato que possibilita ao jogador ratificar ou retificar suas escolhas e ações anteriores geradoras de novas ações e novas etapas a vencer. Esse feedback imediato é um elemento importantíssimo para que o jogador saiba o que precisa mudar, melhorar ou manter para seguir determinado caminho a fim de conquistar seu objetivo final.

Nesses jogos, normalmente, o objetivo final pressupõe, muitas vezes, um caminho extenso. Então, para não desanimar nem abandonar o jogo, ao longo do percurso, o jogador passa por diversos pequenos desafios que, tradicionalmente, vão aumentando em dificuldade de forma gradativa e isso o prepara para o duelo maior que vem mais a frente. Tais estímulos promovem pequenas conquistas parciais a partir de muitas relações de tentativa e erro, tentativa e erro, que algumas vezes podem até ser tentativas por repetição, mas em variados jogos, analógicos ou digitais, gera a necessidade da reflexão, da troca de experiências com outros jogadores, da percepção e entendimento do erro para refazer o caminho até alcançar o acerto. Essas pequenas conquistas, então, se concretizam por meio de várias ações e reações, muitas delas com diversas perdas que sempre podem ser superadas com novas oportunidades para se vencer o obstáculo e se superar a si mesmo. Somadas essas pequenas vitórias, embora tenha em seu histórico várias pequenas derrotas, o jogador acaba por atingir o seu objetivo maior, tendo força, ânimo e experiência suficientes para enfrentar e ultrapassar o último obstáculo.

Essa minha leitura dos jogos serve tanto para os analógicos quanto para os digitais. Como exemplo, opto por trazer um clássico digital que as crianças com as quais trabalho têm muita familiaridade: o jogo digitalMario Bros. Eu poderia citar outros, mas esse é facilmente reconhecido até mesmo por pessoas que não têm intimidade com videogames, pela figura emblemática do personagem principal: um homenzinho de bigode grande, macacão azul, luvas brancas e boné vermelho grafado com a letra " $\mathrm{M}$ "1.Esse exemplo nos permite enxergar mais

\footnotetext{
${ }^{1}$ Se necessário, a imagem desse personagem pode ser vista na internet: <http://migre.me/r3DtD>
} 
concretamente com que visão de mundo e, ouso dizer, de aprendizagem, a criança cresce e se desenvolve até chegar nos bancos escolares enfileirados do Ensino Fundamental.

Foi a percepção da importância desse e de diversos outros jogos na atenção e no desenvolvimento das crianças com as quais interajo que me levou a buscar, por meio deles, uma mudança em minha prática docente ${ }^{2}$. Entendo essa necessidade e até urgência atual, porque a escola para todos é bem diferente da escola seletiva de décadas atrás. A escola para todos precisa se adequar às diferentes realidades com que se depara. E, para tal adaptação, Macedo, Petty \& Passos (2007) propõem “valorizar o lúdico nos processos de aprendizagem”, pois isso significaria, entre outras coisas, considerá-lo na perspectiva das crianças. Eles afirmam que somente o que é lúdico faz sentido para essa juventude e, de certa forma, exortam que

escola obrigatória que não é lúdica não segura os alunos, pois eles não sabem nem têm recursos cognitivos para, em sua perspectiva, pensar na escola como algo que lhes será bom em um futuro remoto, aplicada a profissões que eles nem sabem o que significam. (MACEDO; PETTY; PASSOS, 2007, p. 17).

Esses mesmos autores iniciam seu livro dizendo que o brincar é fundamental para o desenvolvimento do ser humano e que é a atividade principal das crianças quando não estão voltadas às suas necessidades de sobrevivência (eu acrescento que mesmo no preparo para o descanso e na alimentação, exemplos que eles usam de necessidades de sobrevivência, as crianças "ludificam" o processo). "Brincar é envolvente, interessante e informativo." (MACEDO; PETTY; PASSOS,2007, p. 13)

Tomando, então, essa perspectiva de que a criança "ludifica" o seu estar no mundo e suas ações, e de que os jogos - sejam de videogames ou não - permitem um desenvolvimento gradativo e constante em seu processo bastante interessante e encorajador, defendo a ideia de que a escola hoje, para atingir a todos em sua variedade de origens, estímulos e expectativas, precisa (re)conhecer e assimilar o que há de bom e interessante nos jogos para trazer para a dinâmica da sala de aula.

\footnotetext{
${ }^{2}$ É preciso ter claro que, do ponto de vista pedagógico, jogos e brinquedos digitais com os quais estamos lidando hoje promovem uma abordagem diferente, por exemplo, no imediatismo da ação e reação, para a construção da aprendizagem, e é essa abordagem a que as crianças e jovens estão expostos desde que nascem que os leva a criar novas expectativas, interesses e exigências de interação na sala de aula.
} 
Quando o estudante fracassa na escola e, consequentemente, repete o ano, ele se sente desinteressado por aquilo que lhe está produzindo dor, sua reação tende a ser de fuga, porque sente o peso da derrota, a crítica dos que estão em torno dele, o que faz com que, muitas vezes, sinta-se sem força e ânimo para tentar novamente. A sociedade o condena a uma imagem de si mesmo de incapacidade e culpa pessoal. Nos jogos, em geral, essa relação é totalmente diferente. Há, na verdade, muitos jogos em que a única maneira de aprender a jogá-los é tentando e experimentando inúmeras vezes, fracasso, após fracasso, até atingir o sucesso (GEE, 2010). O que tiro disso, portanto, é que boa parte dos jogos $^{3}$, principalmente os atuais de videogame ou jogos de aventura, nestes incluso o jogo tipo RPG, levam os jogadores a terem uma relação positiva com o fracasso porque é vista como um desafio que pode ser enfrentado muitas vezes. A escola, ao contrário, leva seus estudantes a terem uma experiência quase sempre negativa e autodepreciativa, promovendo sensação de impotência e de medo em relação ao mesmo, até porque o foco, na maior parte das vezes, está no resultado, e não no processo.

Salen \& Zimmerman (2012) ratificam essa questão já mencionada por mim na perspectiva do jogo e eu faço a correlação com a escola. Segundo esses autores, o jogo não propicia apenas um objetivo de longo prazo - como a escola o faz, em que o objetivo do aluno é passar de ano, ao final de duzentos longos dias letivos. Eles afirmam que "o jogador luta na direção dos objetivos de curto prazo cada um com um tipo de prazer" (SALEN; ZIMMERMAN, 2012b, p. 65), e acrescentam:

esse objetivo de curto prazo pode parecer bem simples e, para os jogadores adultos, normalmente é. Mas, para as crianças que lutam para compreender as complexidades estratégicas do jogo, a compreensão dos objetivos de curto prazo e a forma como esses objetivos ligam a mecânica básica de fazer uma marca ao objetivo de longo prazo (...) é crucial para a diversão do jogo.

mesmo pensando em bimestres (equivalente a objetivos de curto prazo), como os os feedbacks na escola são demorados e sem, normalmente, um retorno objetivo, o estudante não identifica necessariamente seus erros e suas limitações para superálos na avaliação seguinte. Essa talvez seja uma das grandes falhas da escola.Isso nos mostra que a escola precisa repensar os seus objetivos e a forma como

\footnotetext{
${ }^{3}$ Excluímos aqui, por exemplo, os jogos de sorte.
} 
proporciona o feedback ao aluno. Esses dois elementos tão importantes no jogo podem fazer grande diferença no processo de aprendizagem e autoestima da criança.

Um problema, no entanto, surge daí: tornar a escola lúdica é trazer o jogo para a escola? É ensinar por meio de jogos? É jogar com os alunos e, a partir do que aparece nos jogos, trabalhar conteúdos? Não, pelo menos, no que entendo como "ludificar" a escola. Vejo que muitos professores quando querem "animar" suas aulas se apropriam de jogos existentes no mercado ou criam a partir deles outros jogos com conteúdos de sua disciplina para trabalhar em sala. Não nego o valor disso, mas não foi esse o meu olhar. O que busquei desde o início foi uma transformação do espaço escolar, num processo constante e ativo, em que cada ação tem o seu peso e pode ser analisada criticamente para saber-se onde foi o erro, se é que foi erro ou outra maneira de abordar o problema e que estruturas de ação mental têm que ser acionadas para o avanço buscado. Não defendo o jogar pelo jogar, mas sim usar a abstração reflexiva que o jogo propicia. Ora, adotar essa concepção de aprendizagem significa mudar o paradigma da sala de aula majoritariamente monológica, entediante e fundamentalmente informativa. Como Jogarou "Ludificar" a/na escola? Essa acabou sendo, sem dúvida, minha questão disparadora da tese.

\subsection{Eu jogo, tu jogas, ele joga... e assim o mundo gira}

Em todos os povos há registro da existência dos jogos. Desde tempos primevos da humanidade, seja no Ocidente ou no Oriente, nos povos ditos bárbaros ou civilizados, o jogo sempre teve importância fundamental como elemento estruturante da construção da inteligência e aprimoramento das estruturas mentais, a ponto de muitos povos escolherem seus líderes pela sagacidade no ato de jogar. Especula-se que sua origem se deu juntamente com o surgimento do Homo Sapiens. Temos hoje o conhecimento de alguns jogos ancestrais, desde o terceiro milênio antes de Cristo, descobertos em escavações arqueológicas e de alguns costumes descritos em textos que chegaram até nós. Há rumores sobre a existência de jogos de origem africana há 7000 anos a.C., mas estudos de maior credibilidade limitam esses achados até o momento em 3000 
a.C.. Independentemente disso, é fato que o jogo tem uma importância direta na constituição do Homem ao que ele é.

Huizinga (2010), reconhecidamente uma autoridade no assunto, em seu livro Homo Ludens, escrito em 1938, afirma que o jogo é anterior à cultura e formador dela. Para o autor, o homem, no processo de evolução da humanidade, se percebe protagonista de sua existência e capaz de se relacionar e dominar as demais criaturas. Talvez por isso esteja convencido de que "é no jogo e pelo jogo que a civilização surge e se desenvolve". A tese central de Huizinga, criador da expressão Homo ludens, é a de que o jogo é uma realidade primitiva, compartilhada até mesmo com os animais, portanto, com existência anterior à cultura, ou melhor, é do jogo, por meio do ritual e do sagrado, que nasce a cultura. Ele dá voz e peso ao jogo para a constituição e existência do ser humano quando coloca no mesmo patamar o homem que faz, fabrica, produz a tecnologia necessária à sua subsistência neste mundo (Homo faber), o homem que sabe (Homo sapiens) e o homem que joga, que brinca (Homo ludens).

No primeiro capítulo do livro cujo título é "Natureza e significado do jogo como fenômeno cultural”, Huizinga (2010, p.3) afirma que

\begin{abstract}
mesmo em suas formas mais simples, ao nível animal, o jogo é mais do que um fenômeno fisiológico ou um reflexo psicológico. Ultrapassa os limites da atividade puramente física ou biológica. É uma função significante, isto é, encerra um determinado sentido. No jogo existe alguma coisa "em jogo" que transcende as necessidades imediatas da vida e confere um sentido à ação. Todo jogo significa alguma coisa. Não se explica nada chamando "instinto" ao princípio ativo que constitui a essência do jogo; chamar-lhe "espírito" ou "vontade" seria dizer demasiado. Seja qual for a maneira como o considerem, o simples fato de o jogo encerrar um sentido implica a presença de um elemento não material em sua própria essência.
\end{abstract}

É possível perceber uma tentativa do autor em elevar a importância do jogo na sociedade, retirando dele a carga pejorativa de brincadeira, trivialidade, futilidade, desocupação e até vagabundagem. Nesse sentido, Huizinga também afirma que o jogo não é somente uma prática infantil, demonstrando que está presente, pelo prazer que gera, em quase todas as relações humanas, independente de idade (p. 10). Para Huizinga, “o jogo é uma função da vida” (p. 9).

Esse autor conceitua o jogo como

uma atividade ou ocupação voluntária, exercida dentro de certos e determinados limites de tempo e de espaço, segundo regras livremente consentidas, mas absolutamente obrigatórias, dotado de um fim em si mesmo, acompanhado de um 
sentimento de tensão e de alegria e de uma consciência de ser diferente da 'vida quotidiana'. (HUIZINGA, 2010, p. 33)

Ele acrescenta ainda que "parece capaz de abranger tudo aquilo a que chamamos 'jogo' entre os animais, as crianças e os adultos: jogos de força e de destreza, jogos de sorte, de adivinhação, exibições de todo o gênero" (HUIZINGA, 2010, p. 33).

O que percebemos com essa definição é que o jogo está ligado

a. à liberdade: o indivíduo joga porque tem vontade de jogar, por desejo, não por obrigação, tem autonomia em sua decisão e há sedução para jogar;

b. à imaginação: o indivíduo evade do mundo real enquanto dura o jogo. (Segundo Huizinga, “Toda criança sabe perfeitamente quando está 'só fazendo de conta' ou quando está 'só brincando'.”, p. 11);

c. à tensão: em todo jogo há a incerteza, às vezes o acaso, o imprevisível, que promovem a tensão dentro do jogo;

d. ao tempo e ao espaço: o jogo ocorre em um local específico (quadra de esporte ou tabuleiro, por exemplo, ou ainda em um campo virtual, como se fosse um "lugar sagrado", fechado) durante um período específico de tempo; e

e. à ordem: sem regras não há jogo.

Isto é, o jogo cria um "círculo mágico" no qual quem está jogando mergulha e se envolve. Ele leva o jogador a descobrir novos caminhos, novas formas para se manter nesse círculo. É essa tensão que gera interesse, prazer e engajamento. O jogo cativa e envolve quem o joga.

Huizinga (2010) também endossa a importância e valor dos jogos ao discutir, por exemplo, a questão da oposição entre jogo e seriedade, já que se costuma afirmar que o jogo não é uma coisa séria, é pura brincadeira, sem benefícios significativos para o Homem. Em sua percepção sobre os valores das palavras em relação aos opostos mostra um contraste que não se confirma em todos os sentidos. Para muitos, jogo se opõe à seriedade. No entanto, se jogo se opõe a seriedade, pode-se dizer que "o jogo é a não-seriedade", mas não se pode dizer que "o jogo não é sério" (HUIZINGA, 2010, p. 8). Afinal, todo jogo é sempre seriíssimo para quem o joga, porque pressupõe atenção e concentração mesmo que aos outros, que não entraram ou até desconhecem esse "círculo 
mágico", pareçam apenas brincadeiras inconsequentes. Além disso, ouvindo Piaget, “todo jogo é, num certo sentido, altamente 'interessado', pois o jogador se preocupa certamente com o resultado de sua atividade" (PIAGET, 1978, p. 189).

Piaget classifica os jogos em três grandes estruturas: Jogos de Exercícios, Jogos Simbólicos e Jogos de Regras. Esta última foi a que mais me interessou, pois os dois primeiros predominam, de forma mais direta, às crianças em idade inferior àquelas de minha pesquisa. No entanto, sabemos que as sensações e experiências perpassam esses estágios, independentemente da idade, como por exemplo, no jogo de exercício, predominante no período sensório-motor da criança, em que ela busca a satisfação de suas necessidades a partir, por exemplo, do chupar da mama de sua mãe ou da chupeta etc., atividades que lhe dão muito prazer. Esse prazer funcional caracteriza as primeiras ações humanas que dão origem ao jogo e esse jogo segue também na vida do Homem ao longo dos diversos estágios por que passa, sempre em busca de satisfações prazerosas.

Na segunda estrutura, isto é, no Jogo Simbólico, a criança começa a utilizar a simbologia na interação. Já com um domínio da linguagem falada, ela elabora imagens mentais e ressignifica, por intermédio do brinquedo e da brincadeira, situações da realidade, como a perda de um ente próximo, a chegada de um irmão etc. O que vemos é que, por intermédio do jogo, a criança se adapta a um mundo imaginário que ainda não compreende de fato e, com isso, vai assimilando a realidade para si própria.

A terceira estrutura, como disse antes, foi diretamente importante para esta pesquisa, diz respeito ao Jogo de Regras:

Em resumo, os jogos de regras são jogos de combinações sensório-motoras (corridas, jogos de bola de gude ou com bolas etc.) ou intelectuais (cartas, xadrez etc.), com competição dos indivíduos (sem o que a regra seria inútil) e regulamentados quer por um código transmitido de gerações em gerações, quer por acordos momentâneos. Os jogos de regras podem ter origem quer em costumes adultos que caíram em desuso (de origem mágico-religiosa etc.), quer em jogos de exercícios sensório-motores que se tornaram coletivos, quer, enfim, em jogos simbólicos que passaram igualmente a coletivos mas esvaziando-se, então, de todo ou parte do seu conteúdo imaginativo, isto é, de seu próprio simbolismo. (PIAGET, 1978, p. 185)

Ainda segundo Piaget, essa estrutura se faz presente na vida da criança, predominantemente a partir da entranda na terceira infância, no chamado período operatório-concreto. Nesse período, a criança começa a ter a noção mais concreta de tempo, espaço, do que pode e do que não pode fazer, a partir da noção das 
regras que vão sendo estabelecidas. Ela é capaz também de distinguir e absorver os diferentes pontos de vista. As regras, portanto, passam a conceber as relações sociais. Aliás, é nesse estágio e a partir dele que a criança vai equilibrando a relação do seu eu à vida social. Essa fase também se faz presente ao longo da vida humana, que tem de lidar sempre com perdas e ganhos, derrotas e vitórias, tomadas de decisão, percepção dos erros para elaborar novas ações (e porque não dizer novas jogadas). Para Brenelli (1996, p. 25), o Jogo de Regras

propõe ao sujeito uma situação-problema (objetivo do jogo), um resultado em função desse objetivo e um conjunto de regras. Sua execução, individualmente ou em grupo, impele o jogador a encontrar ou produzir meios em direção a um resultado favorável, inserindo-o num contexto de luta contra o adversário com as suas táticas e estratégias, encatando-o ou atemorizando-o.

Esse adversário, porém, num ambiente escolar, não precisa ser o outro enquanto sujeito. Pode ser - ou deve ser simplesmente - a superação de si mesmo para a aprendizagem e consequente aprovação no final do ano (objetivo real e concreto valorizado pela sociedade e que caracteriza a certeza de que a aprendizagem escolar se fez).

Macedo, Petty \& Passos (2007), inclusive, representam esse adversário sem mencioná-lo, ao mostrarem que existem regras escolares - como assistir às aulas, participar delas discutindo e respondendo às perguntas, realizar os deveres e tarefas - inegociáveis e que o cumprimento de tais regras qualifica quem as cumpre como estudantes:

Os alunos podem realizar essas "obrigações" de muitos modos. Se há pouca resistência e maior investimento, sobra tempo para outras atividades; se há muita resistência e baixo envolvimento, as consequências são negativas e as exigências não diminuem. (MACEDO; PETTY; PASSOS, 2007, p. 106)

Na idade escolar com a qual trabalho, a criança já pode entender a rede das regras e manter o que foi acordado no início, coisa que no período anterior seria sem significação. O jogo de regras pressupõe o mergulho no mundo social. Com ele, ela pode levantar hipóteses, questionar-se e questionar o(s) outro(s) com o(s) qual(is) interage, pois é por intermédio do outro que a criança aprende (PAÍN, 2003; 2009).

Muito antes de pensarmos nos jogos eletrônicos que temos hoje, já vivenciamos, como professores e educadores (e também como alunos), experiências com jogos na escola. Infelizmente, porém, na maioria das vezes, como já disse, ele é destinado a momentos livres, no recreio, aos menores, que 
ainda estão iniciando a sua vivência escolar ou, apenas, nas aulas de Educação Física. Ou se brinca/joga, ou se aprende. Piaget (1978, p.193) não só critica essa rejeição:

a pedagogia tradicional sempre considerou o jogo como uma espécie de alteração mental ou, pelo menos, como uma pseudoatividade, sem significação funcional e mesmo nociva às crianças, que ele desvia de seus deveres. Por seu lado, o senso comum psicológico, dominado por essa espécie de adultocentrismo (...) só via no jogo uma distração ou a manifestação de um desperdício de energia, sem se perguntar por que as crianças antes jogam de tal maneira que de outra.

como também considera que os jogos promovem a relação entre pares, criam situações comunicacionais e interacionais. Aliás, talvez a grande inquietação levantada e discutida por esse autor seja a de que a construção do conhecimento só se faz na (inter)ação em um processo ativo e dinâmico. Em outras palavras, o aluno vai desenvolver melhor a sua capacidade de aprendizagem e vai ser um construtor do conhecimento (seu e do outro, nessa interação), sendo um sujeito ativo nesse processo, pois o conhecimento é fruto da interação entre sujeitosujeito ou sujeito-objeto. De acordo com Oliveira (2009, p.22),

a perspectiva piagetiana para o desenvolvimento do indivíduo supõe um sujeito ativo que constrói não apenas o saber, mas os mecanismos e processos com os quais pode conhecer em uma relação autônoma, espontânea e pertencente ao indivíduo construtor.

Piaget, no entanto, mostra que iniciar um estudo sobre jogo não é simples. Ele abre o capítulo "A explicação do jogo" em seu livro A formação do símbolo na criança: imitação, jogo e sonho, imagem e representação afirmando que

o grande número das teorias explicativas do jogo desenvolvidas até aqui mostra suficientemente que esse fenômeno resiste à compreensão causal. Mas a razão dessa resistência é talvez que se tende a fazer do jogo uma função isolada (como, aliás, da própria 'imaginação'), o que falseia o problema, levando à procura de soluções particulares, ao passo que o jogo tende sem dúvida simplesmente para um dos aspectos de toda atividade (como a imaginação em relação ao pensamento) (PIAGET, 1978, p. 188).

Além disso, ele expõe que não dá para analisar o jogo em um contexto isolado. É necessário entendê-lo como um fenômeno lúdico mais geral. Esse autor considera o jogo como algo essencial na vida da criança, permitindo-lhe desenvolver, entre outras coisas, noções de autonomia, cooperação e ordem, além da capacidade de raciocinar e julgar. Ele expõe que por intermédio do jogo a criança se apropria do que percebe de sua realidade, a fim de que ela não permaneça estranha ao seu conhecimento, e a assimila, podendo transformá-la. 
Essa apropriação e assimilação se dão de acordo com a vivência e experiência da criança com o mundo que a cerca. Brougère (2004) trata também dessa questão quando diz que o brinquedo e as brincadeiras têm uma ligação direta com a cultura e a época em que a criança vive. Isso fica muito claro quando Piaget cita a grande novidade da época, o automóvel:

o conteúdo dos jogos varia segundo o meio físico e social da criança. O automóvel, por exemplo, transtornou as fases e hoje até mesmo as crianças mais jovens, quando deles têm experiência, brincam de imitar as mudanças da velocidade e os dramas do arranque, que não correspondem a nenhuma hereditariedade biogenética! (PIAGET, 1978, p. 201).

Essa percepção faz muito sentido hoje com as transformações da sociedade com o advento da cultura do digital. Ribeiro (2011 p.31) diz que "a multiplicação dos brinquedos eletrônicos, com o surgimento dos videogames mudou a experiência lúdica das crianças e transformou essa cultura de infância".

Hoje a criança desde a mais tenra idade toca as telas para descobrir o mundo que a cerca. As respostas às suas perguntas vêm rapidamente do toque da ponta dos dedos e da tela brilhante. Esse movimento constante de "pergunta-resposta", "ação-reação", "acerto-erro-acerto" (com outras possibilidades relacionais) desenvolve uma visão de mundo e de interação - seja com a informação, seja com o sujeito que está a seu lado ou a quilômetros de distância, ou ainda com o conhecimento que se constrói - diferente do que conhecíamos até então. Paín (2009, p. 21) nos mostra isso quando diz que

não são apenas pessoas que transmitem conhecimento; qualquer objeto transmite conhecimento, pois é algo fabricado, contendo em seu funcionamento o princípio pelo qual foi fabricado. Quase todos os objetos manipulados pela criança em seus primeiros anos já estão culturalizados, mesmo que ela nasça em um meio no qual a natureza esteja mais presente. A natureza está culturalizada e o que não está culturalizado passa despercebido pela criança.

E isso não se mantém apenas diante de uma tela. Isso é assimilado no modo de ser e de estar do sujeito no mundo. Parafraseando Piaget, a existência do automóvel por si só transtornou as fases e modificou as brincadeiras das crianças. Da mesma forma, e muito mais intensamente, a cultura digital na qual as crianças

\footnotetext{
${ }^{4}$ Ribeiro desenvolveu sua pesquisa sobre o lúdico na Educação Física no Colégio Militar de Campo Grande e se baseia também em Brougère nessa leitura que faz da experiência lúdica. Aliás, dialogo com Ribeiro em minha tese por ter realizado sua pesquisa numa instituição semelhante à instituição em que realizei a minha. Vários outros autores e trabalhos de Mestrado e Doutorado que discorrem sobre o lúdico, porém, baseiam-se nos mesmos referenciais que uso aqui e tratam especificamente de uma disciplina (Química, Geografia, por exemplo) ou de crianças no universo da Educação Infantil. Por isso não considerei necessário mencioná-los.
} 
nascem hoje e em que nós, professores, estamos adentrando enquanto adultos, principalmente nos últimos vinte anos, transformou e ainda vai transformar mais o modo como nos comportamos na sociedade e como vemos as relações e funções sociais. É nesse sentido que busco a "metamorfose" da sala de aula, independente da existência e uso de tecnologias de base digital. Aliás, como já afirmei, diferente da época em que fiz a minha pesquisa de Mestrado, hoje já entendo claramente que não é a presença da tecnologia que pode alterar o modo de ensino, mas sim a compreensão do que a tecnologia digital fez no modo de ser e de estar no mundo. Em outras palavras, a tecnologia digital não é em si imprescindível na sala de aula, mas a concepção do que ela produziu no entendimento de como o ser humano age e interage no mundo, sim. A escola é um ambiente que tem de estar pronto para enfrentar novos desafios. Não dá mais para insistirmos em práticas pedagógicas inerentes a uma estrutura industrial, massificada, linear, quando a apropriação do que o digital gerou já está sendo talhado desde o nascimento das últimas gerações que hoje frequentam os bancos escolares.

Acredito que Geertz ${ }^{5}$ (1989) pode ratificar essa ideia do novo sujeito esperando/almejando uma nova escola, quando nos mostra que o homem se forma/se constrói por e no meio cultural em que está inserido e também modifica esse meio em que vive. O que posso, então, traçar sobre o que estamos vivendo hoje e o que se projeta para um futuro já presente em nossos dias é a valorização e construção do que pode vir a ser a onipresença do digital, paradoxalmente mesmo não estando, de fato, presente no uso didático da sala de aula.

Essa realidade está cada vez mais concreta na vida dos indivíduos que estão começando a perder a noção da distinção entre o off-line e o on-line em seus afazeres diários, visto que os diversos dispositivos extensivos ao corpo (celulares, tablets...) permitem interações on-line em tempo real e síncrono, misturadas às interações pessoais presenciais. Os dispositivos móveis tornaram-se nossos olhos, como se fossem extensão de nosso corpo.

Se antes a presença de dispositivos digitais era rara e vivíamos com base do presencial e da incensação da memória mecânica, em menos de vinte anos

\footnotetext{
5 “A cultura fornece o vínculo entre o que os homens são intrinsecamente capazes de se tornar e o que eles realmente se tornam, um por um. Tornar-se humano é tornar-se individual, e nós nos tornamos individuais sob a direção dos padrões culturais, sistemas de significações criados historicamente em termos dos quais damos forma, ordem, objetivo e direção às nossas vidas." (GEERTZ, 1989, p. 64)
} 
mudamos o conceito de experiências presenciais. Hoje a reprodução da imagem, o olhar através da lente que detecta o que se está vendo, vivendo e fazendo naquele momento, para partilhar com tantos outros que ali não estão, ampliam nossa presença e ação, mas também podem tornar fugaz a nossa relação com os fatos vividos. São essas as mudanças que temos de entender enquanto professores de uma escola no século XXI.

A evolução que já aconteceu com a comunicação (as classes C e D brasileiras já estão inseridas nesse processo com os celulares pré-pagos) agora está sendo desenhada com o entretenimento. Isto é, como a necessidade de comunicação já foi suprida, visto que conseguimos falar e contatar o outro com rapidez, facilidade e por preços acessíveis, agora há uma necessidade de suprir a demanda por entretenimento. Talvez por isso, estejamos vendo o crescimento da demanda por jogos e aplicativos sociais e culturais com estruturas de jogos para celulares e tablets, que vão muito além de meros passatempos: os jogos mais elaborados e complexos também já entraram nessas plataformas.

Hoje, por exemplo, assistir a um programa de televisão em que o seu voto, na hora, mudará o resultado do que vai acontecer na história, ou, ainda, ajudar a decidir quem é a banda vencedora do concurso, ou o Brother mais "legal" da casa, já não é mais novidade. Esses recursos criados para manter o telespectador diante da telinha já existiam também na era clássica do rádio quando se ligava para escolher a música e a mais votada era repetida em um horário nobre. Mas esse processo vem evoluindo... Os profissionais de mídia, marketing e publicidade estão sempre atrás de meios para interessar e fidelizar seu cliente no consumo de determinado produto, marca ou ideia. Podemos até não ter a consciência do ato em si, mas quando consumimos um produto para colecionar um brinquedo novo lançado a cada semana (exemplo Mc Lanche Feliz, da rede Mc Donald's), quando fazemos check in em cada lugar aonde vamos pela Rede Social Foursquare ou avaliamos hotéis, restaurantes e pontos turísticos no TripAdviser para compartilhar experiências e ganhar emblemas referentes ao quantitativo de vida social ativa que temos, quando compramos um tênis novo e nos associamos a uma rede social de corredores para partilhar os quilômetros diários percorridos e competimos com nossos amigos também "plugados", quando fazemos dieta utilizando um aplicativo que pontua nossos ganhos e perdas para que amigos 
também nos apoiem etc., estamos mergulhando no ludus da vida atual: sejamos todos bem-vindos (ou não, para os que se incomodam em viver no "show de Truman”) a um mundo lúdico em sua essência. Somos todos Homo ludens!

Em outras palavras, o que estamos vendo, então, é que a sociedade atual tem grande parte de sua estrutura com base no entretenimento, que não é coisa nova, já que desde sempre o homem pratica rituais e festeja suas divindades. Entretanto, com a evolução de nossa sociedade para o que temos hoje, percebemos que há uma nova maneira de se pensar e se aprender pela via do entretenimento, cada vez mais disponível e acessível para todos, apesar de seu grande viés de consumo e de isolamento do seu entorno. Gadgets $^{6}$ e jogos são realíssimos para a juventude do século XXI, como se fossem um mundo paralelo e real da vida diária e extensão de seu corpo (o celular, por exemplo), ora interagindo presencialmente com os que com ele partilham dos mesmos hábitos, ora mergulhando em um mundo de pura simulação solitária ou em grupo. E é o caráter lúdico disso tudo que tem atraído cada vez mais e mais usuários.

Propor, então, uma mudança de paradigma da sala de aula pressupõe entender as transformações pelas quais a sociedade vem passando e como essa relação dos jovens com os gadgets já transformou o seu modo de ser e de estar no mundo, promovendo uma crise de gerações com um gap ainda maior por ser potencializada pelo corte epistemológico provindo das tecnologias digitais. Martins (2015), de forma bastante objetiva, diz que é necessário reconhecer os hábitos dos estudantes fora da escola, o modo como eles se comunicam, como interagem, como resolvem seus problemas em redes, para levar para dentro da escola, já que ela faz parte do contexto em que o jovem está inserido.

\subsection{Na verdade, o que importa: o jogo ou a fantasia do jogo?}

O Dicionário Houaiss da Língua Portuguesa apresenta as seguintes acepções para "lúdico":

1. relativo a jogo, a brinquedo.

${ }^{6}$ Gadgets é o nome geral que se dá para celulares, tablets ou quaisquer outros dispositivos eletrônicos portáteis com os quais andamos e interagimos nessa cultura do digital em que vivemos. 
2. qualquer objeto ou atividade que vise mais ao divertimento que a qualquer outro objetivo (observava a criança em seus exercícios lúdicos: corria, saltava, dançava...).

3. que se faz por gosto, sem outro objetivo que o próprio prazer de fazê-lo (trabalhar com leitura, para eles, era uma atividade lúdica.).

4. relativo à tendência ou manifestação (artística ou erótica) que surge na infância e na adolescência sob a forma de jogo.

Observando as duas primeiras acepções, podemos supor porque talvez haja tanto preconceito em relação ao lúdico na escola. Relacionar o lúdico meramente à ideia de divertimento ou ao brinquedo e ao jogo, sem buscar o que há por trás dessas questões que geram tanto prazer é perder o que há de mais relevante nesse atributo. É lúdico no jogo o que é desafiador; o divertimento provoca movimento, ação, participação, dinâmica, desempenho; a brincadeira pressupõe diversão. Lúdico, então, está muito além da brincadeira em si ou do jogo, ou ainda daquilo que é obrigatoriamente divertido. Na prática, lúdico nem mesmo precisa ser de todo agradável ou mesmo engraçado para aquele que realiza a atividade. Se assim o fosse, Macedo, Petty \& Passos (2007) dizem que poderíamos ficar reféns das crianças e da necessidade de fazer algo recreativo embora desprovido de sentido. Lúdico é tudo aquilo que provoca, desafia, encoraja (a realizar) uma ação por parte de quem foi instigado por algo ou alguém. Se, como diz Winnicott (1975, p. 63), "brincar é fazer" e "o natural é o brincar”, o natural, então, é fazer do mundo um espaço lúdico, e isso tem de incluir um dos pilares da sociedade: a educação escolar.

Negrine (2001, p. 41) pontua o valor que as atividades lúdicas têm no desenvolvimento e na promoção de aprendizagens significativas. Para ele, tais atividades favorecem "a aproximação das pessoas para realizarem atividades sem juízo de valor"; uma melhor compreensão mútua das pessoas; e, ainda, promovem "crescimento intrapessoal, possibilitando melhoras consideráveis nas relações interpessoais".

Santos e Cruz (2011) complementam essa ideia afirmando que a ludicidade, além de ser uma premência do ser humano em todas as idades, não pode ser considerada simples diversão. Diversos autores afirmam que o lúdico facilita a aprendizagem, os processos de socialização, a comunicação, a expressão, 
promove o desenvolvimento pessoal, afetivo, social e cultural. (MAIA, 2014; MORGON, 2013; FORTUNA, 2000).

Para Negrine (2001, p. 42), inclusive, a ludicidade tem de ser pensada como ciência:

Pensar a ludicidade como ciência é, antes de mais nada, adotar estratégias de intervenção pedagógica que nos possibilite não apenas oferecer e oportunizar momentos lúdicos, mas extrair deste tempo substrato que permita interpretar o valor que as pessoas atribuem a estes momentos.

e clarifica que a ludicidade como ciência está ancorada em quatro eixos distintos em sua natureza. São eles:

Sociológica porque atividade de cunho lúdico engloba demanda social e cultural. Psicológica porque se relaciona com os processos de desenvolvimento e de aprendizagem do ser humano em qualquer idade em que se encontre. Pedagógica porque se serve tanto da fundamentação teórica existente, como das experiências educativas provenientes da prática docente. Epistemológica porque tem fontes de conhecimento científicos que sustentam o jogo como fator de desenvolvimento.(NEGRINE, 2001, p. 42 - grifos do autor)

Vendo dessa forma, o lúdico ganha um valor a mais ao seu papel na aprendizagem escolar. Como ciência é preciso estudar o lúdico, conceituá-lo, tecer teorias e realizar práticas variadas passando por processos de investigações de base quantitativa e base qualitativa.

Ludus est necessarius ad conservationem humanae vitae ${ }^{7}$,dizia Tomás de Aquino. (TOMÁS DE AQUINO, apud LAUAND, 2006, p. 3). De acordo com Lauand (2006, p. 32), em sua análise sobre a prática do lúdico na pedagogia medieval, "Tomás (...) situa o lúdico, o brincar de Deus, nos próprios fundamentos da realidade e no ato criador da Sabedoria divina". Ele acrescenta que, para Tomás de Aquino (século XIII),

Deus brinca. Deus cria, brincando. E o homem deve brincar para levar uma vida humana, como também é no brincar que encontra a razão mais profunda do mistério da realidade, que é porque é 'brincada' por Deus. ( LAUAND, 2006, p. 3 grifos do autor)

Platão destacou a importância do aprender brincando. Sócrates, Aristóteles, Sêneca e Tomás de Aquino indicaram a recreação como essencial para o descanso do espírito. Horácio e Quintiliano se referiram à sedução dos doces em forma de letras para facilitar o aprendizado da leitura e da escrita. Erasmo, Rabelais e Basedow viam na brincadeira a conduta livre que favorece o estudo e o desenvolvimento da inteligência. (VASCONCELOS, 2006, p. 59)

\footnotetext{
${ }^{7}$ Tradução: "O brincar é necessário para a vida humana (e para uma vida humana)." (LAUAND, 2006, p. 44)
} 
O lúdico se torna fundamental na educação, porque a escola "obrigatória para todos" precisa envolver as crianças que nela estão apesar de não terem um real incentivo nem consciência da necessidade disso para seu futuro (MACEDO; PETTY; PASSOS, 2007). Se a escola não desafiar a criança que nela entrar, não conseguirá cumprir seu papel, por mais que ela permaneça fisicamente pela obrigação ao longo de todos os anos da Educação Básica.

É necessário entender que não estou propondo aqui uma visão redentora da Educação por intermédio de jogos ou do lúdico. Trago a visão de uma professora que, no exercício prático da função há vinte anos, enxerga a urgência de uma mudança da sala de aula. E, pela sua importância e presença em toda a história da humanidade, enxerga também a ludificação desse processo como uma possibilidade acessível e concreta. Sigo a orientação de Fortuna (2000, p. 9) que defende que

uma aula ludicamente inspirada não é, necessariamente, aquela que ensina conteúdos com jogos, mas aquela em que as características do brincar estão presentes, influindo no modo de ensinar do professor, na seleção dos conteúdos, no papel do aluno. (...) o professor renuncia à centralização, à onisciência e ao controle onipotente e reconhece a importância de que o aluno tenha uma postura ativa nas situações de ensino, sendo sujeito de sua aprendizagem; a espontaneidade e a criatividade são constantemente estimuladas. Está aberto aos novos possíveis, daí que sua visão de planejamento pedagógico também sofre uma revolução lúdica: sua aula deve ser uma ação pedagógica conscientemente criada, (...) mas repleta de espaços para o inesperado, para o surgimento do que ainda não existe, do que não se sabe.

E as percepções de Morgon (2013), que explica que espaço lúdico pressupõe ambiente seguro, relações de confiança entre professores e alunos, e entre alunos-colegas. A segurança e a confiança se constroem quando o contexto de troca, de interlocução, de interação é real, acessível e se permite duradouro e, sobretudo, estável. Maia e Araújo (2014), em referência à Educação Infantil, mas que - a meu ver - pode ser estendido ao Ensino Fundamental, sustentam que um espaço e um contexto de segurança proporcionam à criança um desenvolvimento do espaço potencial que é o espaço da criação.

Paín (2014) reconhece que o preconceito em relação ao uso do lúdico no campo da aprendizagem se faz por um mal-entendido, pois ambos não se confrontam, já que não é para se brincar na escola tal e qual se brinca fora dela. Para a autora, o ponto chave é "como implementar no sujeito a capacidade de transformar uma aprendizagem vivenciada geralmente como obrigação, em uma 
brincadeira divertida." (PAÍN, 2014, p. 15). Mesmo concordando com ela, prefiro, como Macedo, Petty \& Passos (2007), não ficar refém dessa última expressão "brincadeira divertida" e a leio como sendo a transformação do obrigatório (e sem sentido) no seu oposto direto. Portanto, parafraseando Paín, a grande questão de hoje é como implementar no sujeito a capacidade de converter uma aprendizagem vivenciada frequentemente como obrigação desinteressante em algo que interesse, fascine, encante, envolva, instigue, provoque, atraia, excite. Paín(2014, p. 15) afirma que tal capacidade

corresponde a características próprias da atividade lúdica: em primeiro lugar, o desafio, o prazer da aventura; logo, a proposição de estratégias distintas; e, finalmente, a coragem de se submeter à prova da realidade.

e Winnicott (1975, p. 80) afirma que

é no brincar [tomo-o como lúdico], e somente no brincar, que o indivíduo, criança ou adulto, pode ser criativo e utilizar sua personalidade integral: e é somente sendo criativo que o indivíduo descobre o eu.

Com base no que apresentei até aqui e ampliando para o lúdico o que Oliveira (2009, p. 16) apresenta sobre o jogo, afirmo, então, que o lúdico é compreendido, com suas dimensões cognitiva, afetiva e social, como um elemento que desencadeia situações "que permitem a inter-relação dos processos e mecanismos necessários à construção do conhecimento".

Seguindo essa concepção, fica claro que o modo como tarefas e problemas são propostos torna-se fundamental para o sucesso ou não da atividade, no que diz respeito ao interesse do aluno e desenvolvimento da criatividade para sua aprendizagem. Isso coaduna com a noção do "desejo do outro" e do "olhar do outro" apresentada por Paín (2009) na constituição do ser humano ${ }^{8}$. Oliveira (2006, p. 86) explica que

a educação não pode ser separada de seu sentido inconsciente, porque esse é coagente e co-produtor dos fazeres humanos, os quais estão sempre implicados no percurso do desejo, do infantil, da fantasia... Dado que o ser humano é, sobretudo, um ser do desejo, mais do que da necessidade, é imprescindível considerar que aprender, pensar e ensinar são atividades investidas de fantasia. Para além da necessidade intelectual, pensar e conhecer aludem à atividade de dominar e destruir enigmas... que é fonte de prazer e de angústia. O que sustenta o saber é a paixão, a alegria de conhecer.

E Mamede-Neves (1999, p.53) afirma que

\footnotetext{
${ }^{8}$ Desenvolvo essa questão na página 167.
} 
há a situação em que o aluno toma o professor como o sujeito do saber e, enquanto tal transforma-o em seu ideal de ego, transferindo para ele o seu ideal de conhecedor, por seu turno, o professor aceita essa depositação de papel, enquanto aquele que ensina. Na verdade, essa idealização e essa aceitação por parte do professor, se provisórias, são fundamentais como expressão de identificação havida entre aluno e professor e construtivas do processo de construção do conhecimento, respectivamente, por parte de cada um deles.

O que entendemos nessas afirmações é que o estudante precisa do outro (no caso, seu professor) com seu desejo e olhar para construir sua própria aprendizagem. Para isso, precisa "ser interessado" pelo outro para que seja dado a ele o "tempo de poder existir como um ser autor" (MAIA, 2014, p. 35). Isso tudo também coaduna com a ideia de "ludus" apresentada por Lauand (2006, p.43). Segundo o autor,

o ludus de que Tomás trata na Suma e na Ética é, sobretudo, o brincar do adulto (embora se aplique também ao brincar das crianças). É uma virtude moral que leva a ter graça, bom humor, jovialidade e leveza no falar e no agir, para tornar o convívio humano descontraído, acolhedor, divertido e agradável (ainda que possam se incluir nesse conceito de brincar também as brincadeiras propriamente ditas).

Afinal, já estava presente desde a Idade Média, na visão desse grande filósofo que o processo de ensino e aprendizagem não pode ser "fastidium", isto é, “não pode ser aborrecido e enfadonho: o 'fastidium’ é um grave obstáculo para a aprendizagem". (LAUAND, 2006, p. 44)

Portanto, resumindo tudo o que foi exposto - numa ideia geral -, o lúdico deve entrar na escola porque é por meio da atividade lúdica que a criança interpreta ou assimila a realidade à sua volta e a si mesma (Piaget, 1970); "ele agrega valores, motiva a participação dos alunos e desenvolve outras formas de construção de conhecimento"(MAIA e VENEGAS, 2014, p. 83).

Parafraseando e citando Santin (2001), um clássico mencionado por muitos autores a quem recorri e que por eles o conheci (sua primeira edição é de 1994), acredito que o lúdico pode atuar realmente na escola quando não houver a preocupação com notas formais, rankings e reprovações, mas com a "humanidade do homem que vem ao nosso encontro com as características do brinquedo e com passos de criança" (SANTIN, 2001, p. 32). O problema é como fazer isso, como tornar lúdicasas disciplinasda Educação Básica. Dizer que basta o docente ludificar a sua prática; o professor se tornar um educador lúdico que realiza ações lúdicas em sua sala de aula certamente é um discurso vazio. Assim o que me propus como a questão de minha tese é, em minha área, transformar realmente 
lúdica a relação mestre-aluno no campo da Língua Portuguesa, num ambiente escolar ainda fortemente impregnado de amarras tradicionais do fazer pedagógico.

\subsection{Uni duni tê: entre o jogo e o lúdico}

No princípio era o jogo, e o jogo estava com o Homem e o Homem era Homo Ludens. Segundo Santos (2001, p. 13),

a expressão homo ludens é uma nomenclatura que começa a fazer parte de nosso cotidiano e, o homem, sem perder sua condição de adulto sério e responsável, passa a dar um novo sentido a sua existência pela via da ludicidade, recuperando a sensibilidade estética e enriquecendo seu interior.

No início de meu texto, apontei que o autor holandês Huizinga (2010) sustenta que o jogo é anterior à cultura e formador dela e também que a civilização surge e se desenvolve no jogo e pelo jogo. Daí sua criação do termo

Homo Ludens, porque somos seres que brincam e, na brincadeira, se forjam e são forjados pelo outro.

Tendo apresentado até aqui o jogo e o lúdicona concepção de autores distintos, foi o lúdico que me apresentou a maior capacidade transformadora dessa escola que temos hoje. Winnicott (1975) afirma que o brincar (e eu novamente tomo esse brincar como o lúdico) é essencial para a manifestação da criatividade. Ele diz que "é no brincar, e talvez apenas no brincar, que a criança ou o adulto fruem sua liberdade de criação" (WINNICOTT, 1975, p. 79) e acrescenta que

é com base no brincar, que se constrói a totalidade da existência experiencial do homem. Não somos mais introvertidos e extrovertidos. Experimentamos a vida na área dos fenômenos transicionais, no excitante entrelaçamento da subjetividade e da observação objetiva, e numa área intermediária entre a realidade interna do indivíduo e a realidade compartilhada do mundo externo aos indivíduos.

Então, se o jogar e o brincar são ações fundamentais e sérias na constituição humana, o lúdico que é a raiz de ambos não poderia agir de forma diferente. É na terceira acepção do Dicionário Houaiss da Língua Portuguesa que se entende que o lúdico pode ser qualquer atividade que se faça por gosto ou por prazer, sem que a isso esteja associada a ideia de jogo ou diversão, embora a diversão pareça intrínseca ao prazer. Logo, trazer o lúdico para a escola significa trazer a seriedade do desafio que é o aprender e promover a possibilidade do interesse e do prazer que esse desafio pode causar. 
É claro que eu não estou negando o jogo ou a brincadeira em si. Não defendê-los não é negá-los. Existem diversas situações em que ambos são muito úteis se bem aplicados. Prefiro, no entanto, usar a noção de jogo e de brincadeira como um fenômeno lúdico mais geral.

Por todo o exposto, vê-se que o jogo, como apresentei no início, é um campo de grande interesse das crianças e jovens hoje (e sempre), e que a sociedade atual está mergulhada (ou mergulhando) em interações diversas de base lúdica. Então, iniciei minha pesquisa com a percepção de que o uso derecursos e estratégias embebidos no lúdico poderiam trazer uma transformação de minha sala de aula. 


\section{Metodologia}

A pesquisa foi realizada no segundo semestre escolar de 2014 em duas turmas de $6^{\circ}$ ano do Ensino Fundamental do Colégio Militar do Rio de Janeiro (CMRJ). Foram ao todo oitenta aulas de quarenta e cinco minutos cada (sendo quarenta e cinco, no terceiro bimestre letivo e trinta e cinco, no quarto), realizadas do dia 14 de julho a 13 de novembro, data da última aula antes do início das

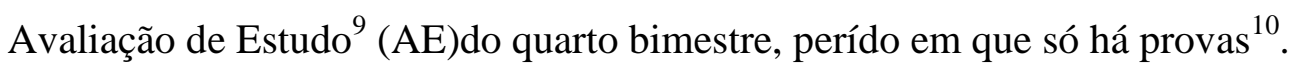

As outras quatro turmas do mesmo ano seguiram com o trabalho sendo realizado pelas duas professoras de Língua Portuguesa (LP) em seu formato tradicional. Considero importante destacar que todas as turmas, ao final de cada bimestre, realizaram a mesma $\mathrm{AE}$ produzida pela coordenadora de Língua Portuguesa da série, uma das professoras das outras turmas, e aplicada conforme as regras do colégio. Portanto, por mais que a estratégia empregada tenha sido diferente, obedeci a todas as regras da instituição para atingir o objetivo final do programa: promover a aprendizagem de determinados conteúdos específicos estipulados para o ano a fim de alcançar a promoção no final do ano.

Quanto ao desenho de minha pesquisa, ela foi, inicialmente, exploratória, tomando o rumo de uma pesquisa-ação, com ênfase no caráter avaliativo de um programa inovador. No entanto, como a estrutura metodológica pressupunha também uma permanente avaliação da professora condutora do processo, apresentou ainda um caráter de autoestudo (self-study), nos termos encontrados em Marcondes e Flores (2014).Tenho que dizer que esse autoestudo se desenvolveu numa estrutura narrativa-descritiva-reflexiva-transformadora por uma professora-pesquisadora. Em outras palavras, somente ao final de toda a pesquisa realizada, pude perceber que o desenho proposto no começo se transformou realmente em um verdadeiro autoestudo, por ter cumprido cada uma das etapas exigidas por estudiosos da área segundo Marcondes e Flores (2014).

De acordo com essas autoras (MARCONDES e FLORES, 2014, p. 298), “a literatura tem enfatizado a importância da construção da identidade profissional como uma dimensão-chave na formação de professores". Para Flores (2015),

\footnotetext{
${ }^{9}$ Nome que se dá, no Sistema Colégio Militar do Brasil (SCMB), para as provas bimestrais.

${ }^{10}$ No mês de setembro também houve uma interrupção de oito dias úteis seguidos sem aulas devido à aplicação das AE.
} 
tornar-se um bom professor envolve mudança pessoal e profissional que vai muito além do conhecimento específico da disciplina que leciona e isso deve ser priorizado em sua formação. $\mathrm{O}$ autoestudo, então, entra nessa perspectiva de uma prática reflexiva a partir de uma investigação-ação, daí ser também uma pesquisaação.

Apesar de haver algumas definições de autoestudo, tomo, em minha pesquisa, o que Loughran (2009) defende. Para o autor, o autoestudo envolve uma análise minuciosa "da própria pedagogia inerente ao processo de ensinar sobre o ensino de modo a desenvolver o conhecimento sobre essa mesma prática" (LOUGHRAN, 2009, p. 18, apud MARCONDES e FLORES, 2014, p. 298). Essa análise deve transcender as reflexões pessoais ordinárias sobre a prática e promover "o questionamento dos pressupostos teóricos que lhe estão subjacentes com rigor e sistematicidade com vista a um melhor conhecimento sobre o ensino e sobre a aprendizagem sobre o ensino"(MARCONDES e FLORES, 2014, p. 298).

Em minha pesquisa, acabei desenvolvendo, quase que de modo natural sem o conhecimento dessa teoria previamente, um autoestudo caracterizado como "sobre si próprio". Em outras palavras, ao atuar, observar e registrar tudo o que fazia nas atividades e como interagia com os alunos ao longo de todo o processo, acabei analisando detalhadamente minha atuação, os dilemas e as questões do ensino sobre o ensino na prática em si,buscando sempre compreender melhor essa minha prática. Isso acabou por gerar uma necessidade de obter noções clarificadas do ensino sobre o ensino.

Seguindo a recomendação de Marcondes e Flores (2014, p. 299), de que "é necessário garantir a articulação entre a inquietação pessoal ou questionamento privado com as questões públicas de um tempo e de um lugar", tenho, hoje, grandes razões para acreditar que realizei uma "pesquisa self-study de qualidade" porque, como investigadora, procurei sempre manter um equilíbrio entre minha biografia e minha história, buscando soluções para questionamentos e inquietações que vão além do privado em minha atuação, porque se fazem presentes no trabalho de quaisquer professores que estão atuando na Educação Básica, na chamada“escola para todos".

Segundo essas autoras a quem recorri para conhecer sobre esse tipo de pesquisa, 
muitos pesquisadores levantam dúvidas sobre a adequação e a aplicação das noções de validade convencionais. Erickson (apud DENZIN; LINCOLN, 1998) enfatiza que a validade, nesse tipo de pesquisa, deveria valorizar o modo como a história é contada e a qualidade da evidência que é veiculada para a sua autenticidade. De acordo com Feldman (2003), podemos aumentar a validade do nosso "autoestudo" procurando tornar público os modos pelos quais construímos as nossas representações de pesquisa. O autor sugere alguns modos (p. 27). O primeiro é apresentar clara e detalhadamente a descrição do modo como os dados foram recolhidos e colocar explicitamente o que conta como "dado" no nosso trabalho. O segundo é fornecer uma clara e detalhada descrição de como foi se construindo a interpretação a partir dos dados. Um terceiro modo é estender a triangulação além de múltiplas fontes de dados. O quarto é fornecer evidência do valor das mudanças nos nossos modos de ser um formador de professores. Se o tipo de pesquisa "autoestudo" é uma atividade moral e política e tem como objetivo uma mudança no modo de ser do professor ou formador, então deve haver alguma evidência do seu valor (LOUGHRAN; NORTHFIELD, 1998). Uma apresentação dessa evidência pode convencer os leitores da validade do estudo que está sendo apresentado. (MARCONDES e FLORES, 2014, p. 300)

Por isso, procurei validar este autoestudo buscando contar, em detalhes, por vezes até de modo exaustivo para o leitor externo, o processo de recolhimento dos dados, como se deu a interpretação a partir deles, as triangulações realizadas e, por fim, a exposição onipresente no meu discurso de tudo que vivi, experimentei, refleti e que gerou questionamentos ou transformações da minha atuação e meu modo de ver a escola, o aluno, a Educação.

\subsection{Ambiente da pesquisa: a instituição Colégio Militar do Rio de Janeiro}

O CMRJ é uma escola pública federal, situada na Tijuca, bairro nobre da Zona Norte do Rio de Janeiro. Conta com um espaço privilegiado com um campus que contém árvores frondosas centenárias, pátios variados, campo de futebol oficial, piscina, área de equitação, ginásio poliesportivo, biblioteca, teatro, cantina e lanchonetes, área militar de tiro, moradia para soldados, ambulatório clínico e dentário, loja de uniformes etc. Com 126 anos de existência completos em 06 de maio de 2015, é o colégio mais antigo do $\mathrm{SCMB}^{11}$.

Há quase quinze anos o colégio funciona apenas no período matutino, mantendo, para todos, o apoio e a recuperação no contraturno. Em 2015, porém, teve início, com o $6^{\circ}$ ano, um projeto experimental de tempo integral,duas vezes

\footnotetext{
${ }^{11}$ Sistema Colégio Militar do Brasil.
} 
por semana. A intenção é que até 2018 seja implantado em todo o Ensino Fundamental $^{12}$.

Convivem em um mesmo espaço uma escola e um quartel. Por esse motivo, o organograma da instituição é bem complexo com um chefe maior, um Coronel Comandante, e subchefias distintas para a Divisão de Ensino e para o quartel, mas as atividades e datas comemorativas de um interferem na atuação do outro.

O SCMB tem um número de vagas que varia de um colégio para outro entre alunos concursados e alunos assistidos pelas regras militares. No Rio de Janeiro, o corpo discente até 2014 era formado por cerca de vinte por cento de concursados que entravam todos os anos na instituição somente no sexto ano do Ensino Fundamental e no primeiro ano do Ensino Médio, e por volta de oitenta por cento de filhos de militares, sendo mais de cinquenta por cento, desse grupo, dependentes de praças ou de oficiais oriundos de $\operatorname{praças~}^{13}$. Foi anunciado, porém, em abril de 2015,o fim das vagas de concurso para o Ensino Médio, sendo mantida somente a entrada de alunos, filhos de civis, por meio de concurso, no $6^{\circ}$ ano do EF.

O alunado, portanto, é muito heterogêneo, seja pela condição socioeconômica (morando, também, em espaços variados e por vezes muito distantes dentro do Estado do Rio de Janeiro), seja pela experiência dessas crianças com acesso a outras culturas desde cedo, pois o trabalho de seus responsáveis exige constantes mudanças de cidade dentro do Brasil e, às vezes, até para o exterior. Isso, inclusive, promove uma grande rotatividade dentro do colégio: cerca de um terço dos filhos de militares entra e sai anualmente da instituição. Isso faz com que haja uma grande dificuldade, sentida pelos professores, em produzir um trabalho coeso e continuado em todos os anos.

A sala de aula da escola que temos hoje, de um modo geral, com raras exceções, se mantém a mesma do início do século passado: paredes praticamente monocromáticas, carteiras enfileiradas, mesa e cadeira do professor e quadro de giz. Não é diferente no colégio em que esta pesquisa foi realizada. Na verdade, tendo tido acesso a uma imagem de uma sala de aula do início do século XX no

\footnotetext{
${ }^{12} \mathrm{O}$ ano de 2016 começou com a extensão do turno integral para o sétimo ano.

${ }^{13}$ Informação passada em palestra em 2015 a todo o Corpo Docente do CMRJ pelo General, chefe da Diretoria de Educação Preparatória e Assistencial (DEPA), responsável maior pelo SCMB.
} 
CMRJ, percebi que a sala antiga continha mais informações/tecnologias da época que as salas da atualidade.

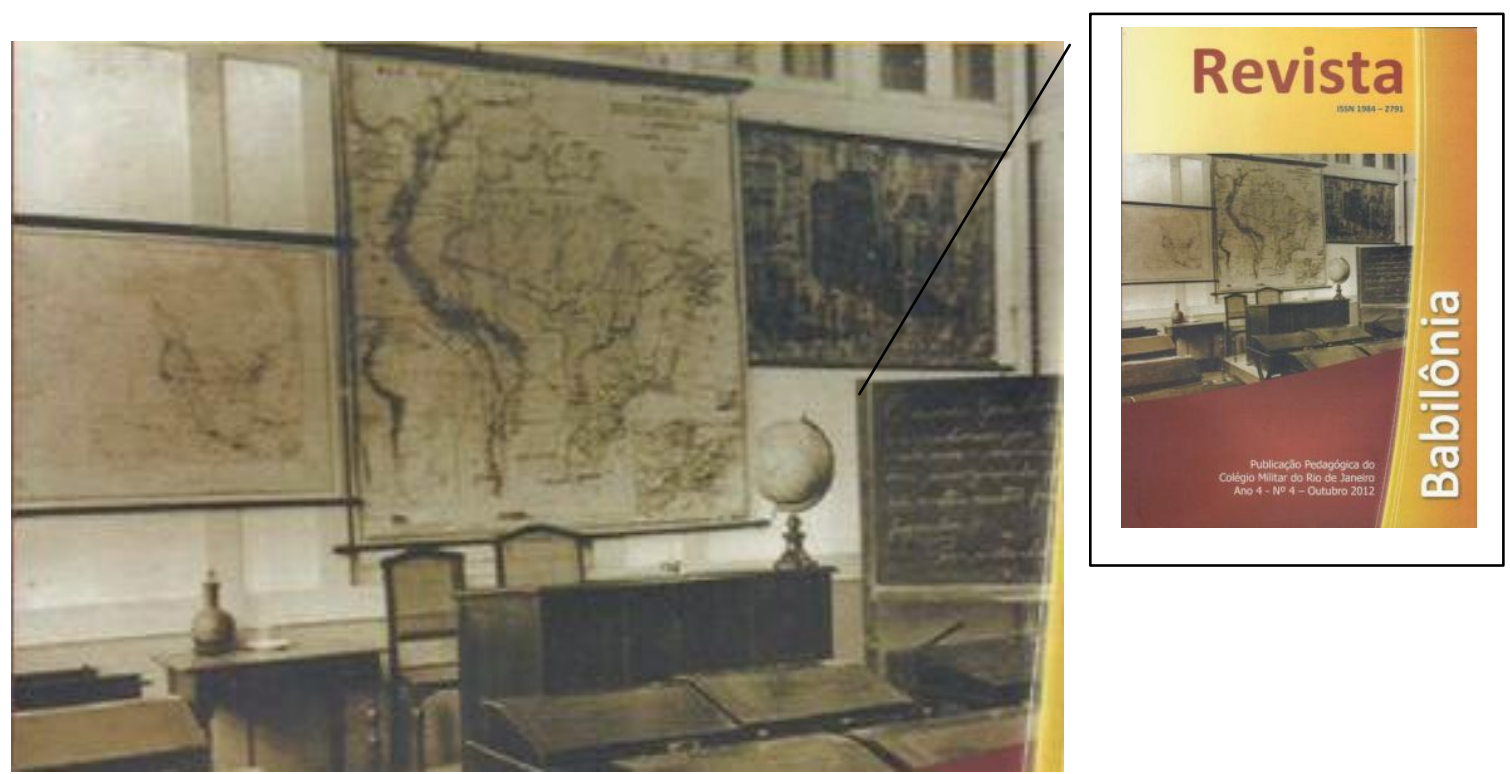

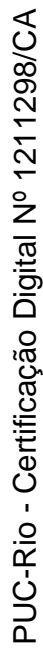

Figura 1: Foto da sala de aula do CMRJ no início do século XX publicada na capa da Revista Babilônia.

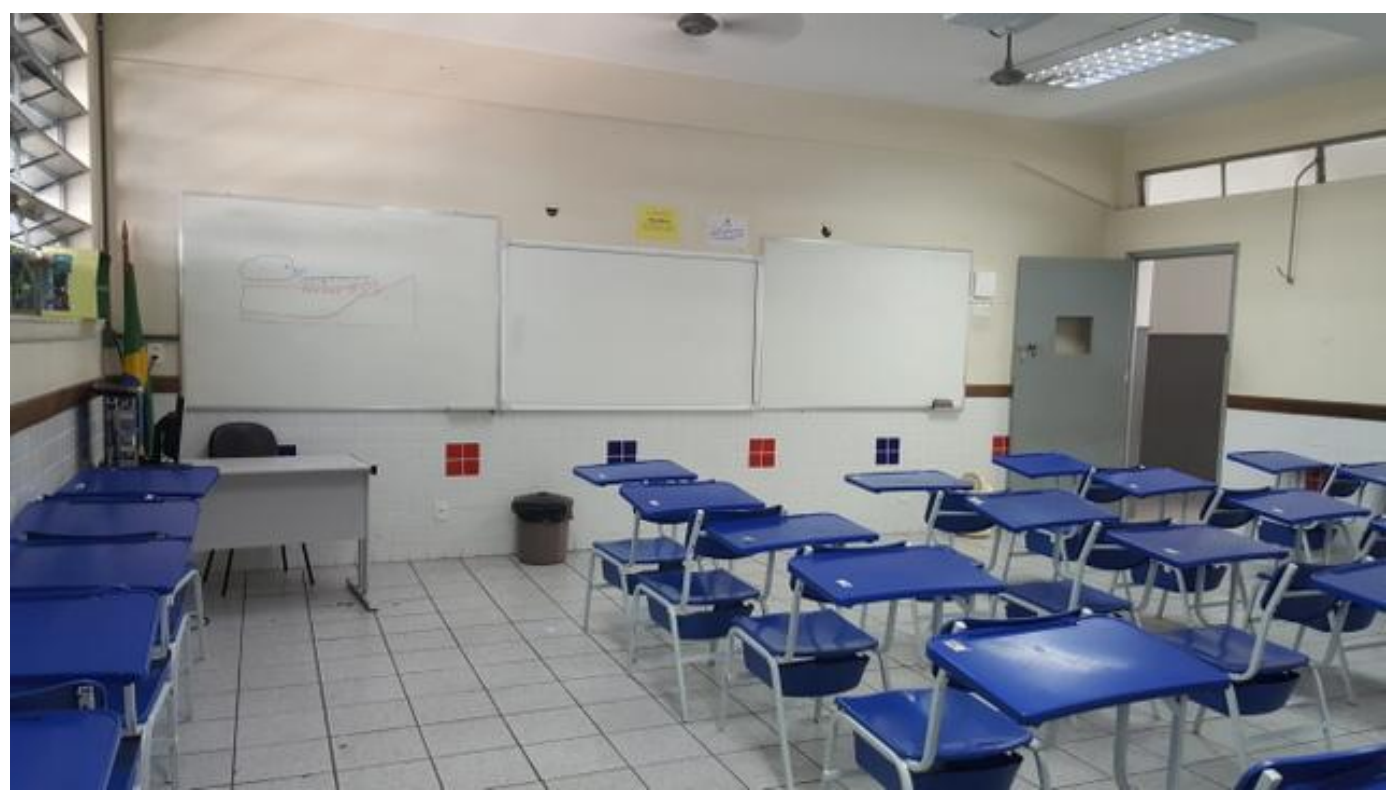

Foto 1: Sala de aula padrão do $6^{\circ}$ ano do EF no CMRJ em 2015.

Embora nas salas em que atuei já houvesse quadros digitais a partir do segundo semestre de 2014, período em que realizei esta pesquisa, tais quadros nunca foram utilizados a contento pela falta de computadores. Os professores fizeram algumas tentativas com computadores pessoais, com auxílio dos colegas 
de Informática, que estavam sempre disponíveis para nos ajudar e nos dar suporte com a ferramenta específica do quadro digital. Entretanto, diversos problemas surgiram, levando-nos a desistir e a acabar utilizando apenas o data-show como projetor em uma tela branca sem sensibilidade ao toque.

Com relação à infraestrutura específica do $6^{\circ}$ ano durante o segundo semestre de 2014, as salas de aula contavam com cerca de 30 carteiras de alunos, uma mesa de professor com cadeira, uma bandeira do Brasil, quatro ventiladores de teto, um quadro digital no centro à frente e dois quadros brancos, um de cada lado do quadro digital, colocados no lugar do quadro de giz, e um data-show. A ventilação ainda é bem precária com janelas tipo basculante que precisam ser fechadas, muitas vezes, para que os alunos enxerguem o que o professor escreve no quadro durante a aula devido ao reflexo do sol.

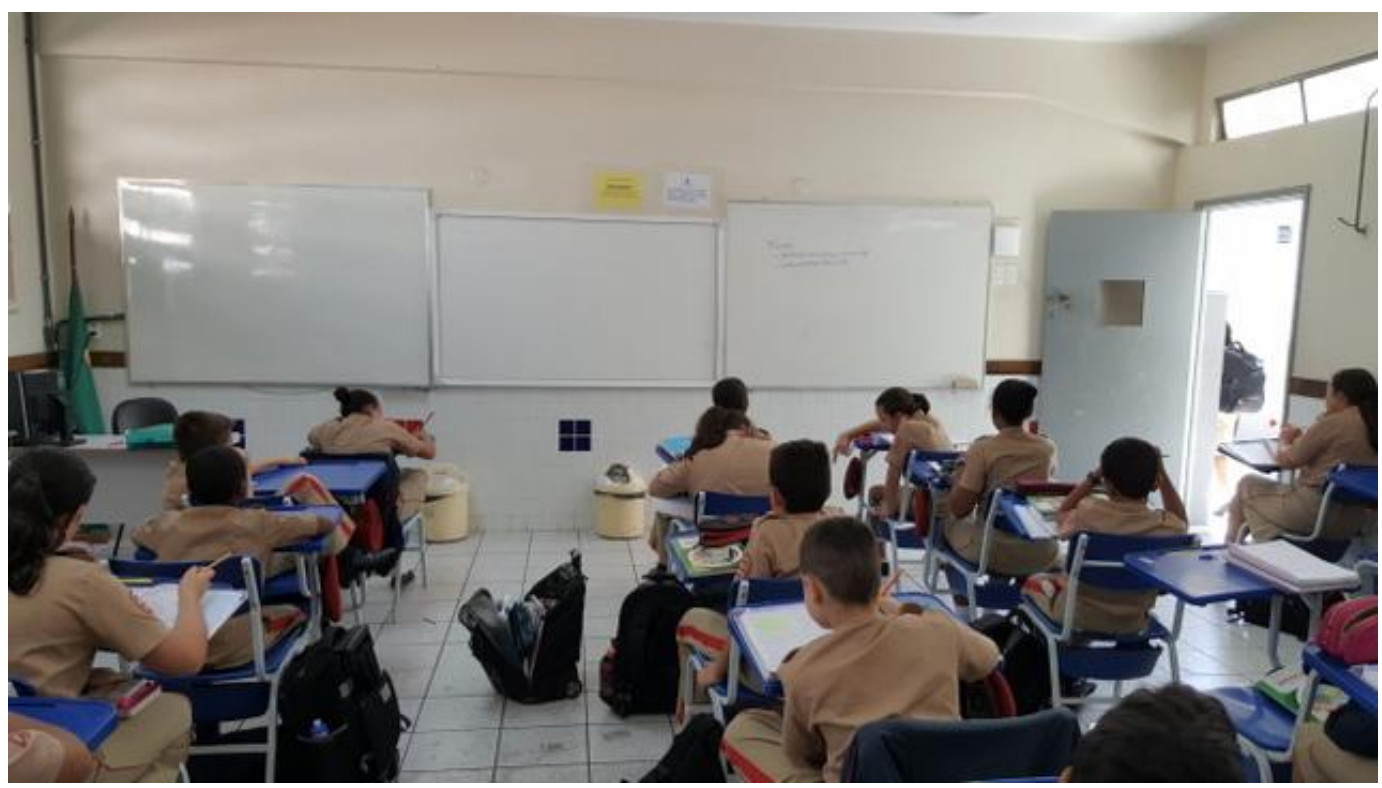

Foto 2: Sala de aula padrão do $6^{\circ}$ ano do EF no CMRJ em 2015 com os alunos enfileirados e naturalmente separados para produção de suas atividades.

$\mathrm{Na}$ experiência que realizei, pude constatar que houve um claro descompasso entre a minha proposta e a cartografia da sala que não estava e não está preparada para uma estratégia diferenciada, que envolva dinâmicas, comunicação constante, trocas e movimentação na sala. Não é necessário chegar a uma escola sem paredes como, por exemplo, a proposta, ao menos teórica, do 
projeto GENTE ${ }^{14}$. Acredito que haja um meio termo com salas mais amplas, claras, arejadas e com possibilidades distintas não só do mobiliário como da disposição dele nesse espaço. Talvez a ideia de as turmas se locomoverem de um tipo de sala para outro seja mais interessante - e menos entediante ${ }^{15}$ - do que ter uma única sala para todas as disciplinas "tradicionais" e sair apenas para aulas de Educação Física e, às vezes, Artes. ${ }^{16}$ Ribeiro (2011, p. 19), apresenta seu testemunho sobre essa realidade ainda hoje dramática:

Durante as aulas que ministro no Colégio Militar de Campo Grande percebi, em quase todos os momentos, a necessidade e o desejo intenso, do aluno de $6^{\circ}$ e $7^{\circ}$ anos (...), de brincar, de se movimentar, de se libertar da imobilidade das salas de aula. Os alunos (...) chegam às aulas de educação física com seus corpos implorando pelo movimento e pela ludicidade, momentos quase únicos, em que poderão, sem culpa ou repreensão, em totalidade, serem crianças no mundo.

Como parte também do ambiente onde foi realizada a pesquisa, o Portal Educandus foi contratado em caráter experimental para este ano letivo a partir do segundo semestre. Eu o utilizei junto com alguns professores que se mostraram mais abertos a essa nova experiência, mas não houve uma grande adesão de fato por parte nem dos docentes nem do corpo discente. No caso dos docentes, há uma explicação importante: o desenvolvimento dependia de um trabalho extra em casa (mesmo depois de cumprimento da carga horária no colégio), para produção de material, já que nem sempre há bom acesso à internet na escola e os poucos computadores que existem nas salas de professores não correspondem ao número de usuários.

\section{2. $O$ ano em que a pesquisa foi realizada: características próprias}

O $6^{\circ}$ ano do Ensino Fundamental era, em 2014, composto por 167 alunos, divididos em seis turmas.Lecionei Língua Portuguesa em duas dessas seis turmas. As outras quatro eram divididas entre duas professoras militares.

\footnotetext{
${ }^{14}<$ http://gente.rioeduca.net/>

15 Mamede-Neves (em comunicação pessoal) lembrou que na década de 40, quando aluna do Instituto de Educação, já havia a proposta pedagógica de sempre os alunos se deslocarem a cada aula para salas específicas, equipadas com o que era necessário para o adequado desenvolvimento de cada disciplina: laboratórios, clubes de leitura etc.

${ }^{16} \mathrm{Na}$ instituição em que realizei a pesquisa, os alunos também se locomovem para as aulas de Inglês, porque as turmas são reorganizadas em níveis. A sala de Artes é uma conquista bastante recente. Antes essas aulas ocorriam na mesma sala das demais disciplinas.
} 
Cada ano contava também com uma equipe de chefias e coordenações distintas ${ }^{17}$. O chefe do $6^{\circ}$ ano na Divisão de Ensino, um militar, atuava nas funções burocráticas do ano em consonância com as questões do quartel, e o coordenador pedagógico $^{18}$ atuava nas práticas pedagógicas e incentivo/trocados/entre os docentes. A chefe disciplinar, também militar, que atuou na Primeira Companhia ${ }^{19}$ durante o ano de 2014 estava sempre em contato com todos os docentes para uma atuação comum com o corpo discente. A Seção Psicopedagógica contava com duas profissionais voltadas para o $6^{\circ}$ ano: uma orientadora educacional e uma psicóloga. Desenvolvemos, nesse ano, um trabalho também diretamente e em conformidade com elas. O Sistema, porém, é regido por uma troca bianual do comando e, quase sempre,trocas anuais de chefia. Infelizmente, muitas dessas alterações ocorrem afetando diretamente o desenvolvimento pedagógico do colégio.

\subsection{Sujeitos da pesquisa}

Os sujeitos de minha pesquisa foram cinquenta e quatro alunos divididos igualmente em duas turmas do $6^{\circ}$ ano do Ensino Fundamental com faixa etária entre dez e treze anos. Eram trinta meninos (dezesseis, na turma que chamarei de A, e quatorze, na turma que chamarei de B) e vinte e quatro meninas (sendo onze, na A, e treze, na turma B). Em conformidade com as regras de realização de pesquisa com menores de idade, para preservação da identidade do aluno, esses sujeitos foram nomeados com um código construído com a palavra "Autor", porque todos produziram e criaram muitos textos, seguida da letra que identifica a turma (A ou B) e um número, aleatório misturado nas duas turmas, de um a cinquenta e quatro. Dos cinquenta e quatro alunos que participaram da pesquisa, eu já conhecia, desde o primeiro semestre, cinquenta e três, pois entrou na turma B, no início do segundo semestre, um aluno novo que veio transferido de Juiz de Fora para completar o ano letivo no Rio de Janeiro.

\footnotetext{
${ }^{17}$ A função de coordenador pedagógico exercida por um professor do ano foi extinta em 2015.

${ }^{18}$ Eu exerci a função de coordenadora pedagógica do $6^{\circ}$ ano em 2013 e 2014.

${ }^{19}$ Nome que se dá na estrutura militar aos anos do Ensino Fundamental: $6^{\mathrm{o}}$ ano, $1^{\mathrm{a}} \mathrm{Cia} ; 7^{\mathrm{o}}$ ano, $2^{\mathrm{a}}$ Cia; $8^{\circ}, 3^{\mathrm{a}}$ e $9^{\circ}, 4^{\mathrm{a}}$. No Ensino Médio os grupamentos de cada ano são dividos pelas armas: Artilharia, Infantaria, Comunicações e Cavalaria. Em 2016, foi aberta a primeira turma de Engenharia, inicialmente, no $1^{\circ}$ ano do Ensino Médio.
} 
Dez alunos ingressaram por concurso, filhos de civis (sendo oito meninos e duas meninas); quarenta e quatro, por direito assistencial (chamados "assistidos" ou "amparados"), filhos de militares. Três alunos já tinham cursado o $6^{\circ}$ ano em 2013 no SCMB, sendo dois no próprio CMRJ. Outros quatro também estavam pela segunda vez no $6^{\circ}$ ano, vindos de outras instituições. Três deles, concursados. Isso é muito comum acontecer nesse grupo, já que o concurso é bastante concorrido e o desejo de entrar no $\mathrm{CM}$ faz com que as famílias optem até pelo retorno em ano.

Encontrava-os às segundas, quartas e sextas, turma $\mathrm{A}$; segundas, terças e sextas-feiras, turma B, ambas com uma carga-horária semanal de cinco tempos, cada tempo com quarenta e cinco minutos de aula, sendo, ao menos, dois tempos obrigatoriamente geminados (uma hora e meia) por turma.

Um questionário de perfil (indicado noAnexo 2) foi aplicado na primeira semana do segundo semestre, como um elemento prévio à pesquisa, a fim de identificar os hábitos de estudo dos alunos e sua relação com as avaliações (percepção deles sobre eles mesmos). Foram 53 respondentes, pois um dos alunos só retornou do recesso do meio de ano na semana seguinte ao reinício das aulas.

Destaco aqui, como parte do (re)conhecimento desse grupo de autores, os dados que se tornaram significativos com relação ao processo de aprendizagem de alguns alunos. Dos cinquenta e três respondentes, vinte e nove disseram ter hábito de estudo diário, enquanto vinte e um afirmaram só estudar quando precisam, como apresenta o gráfico abaixo:

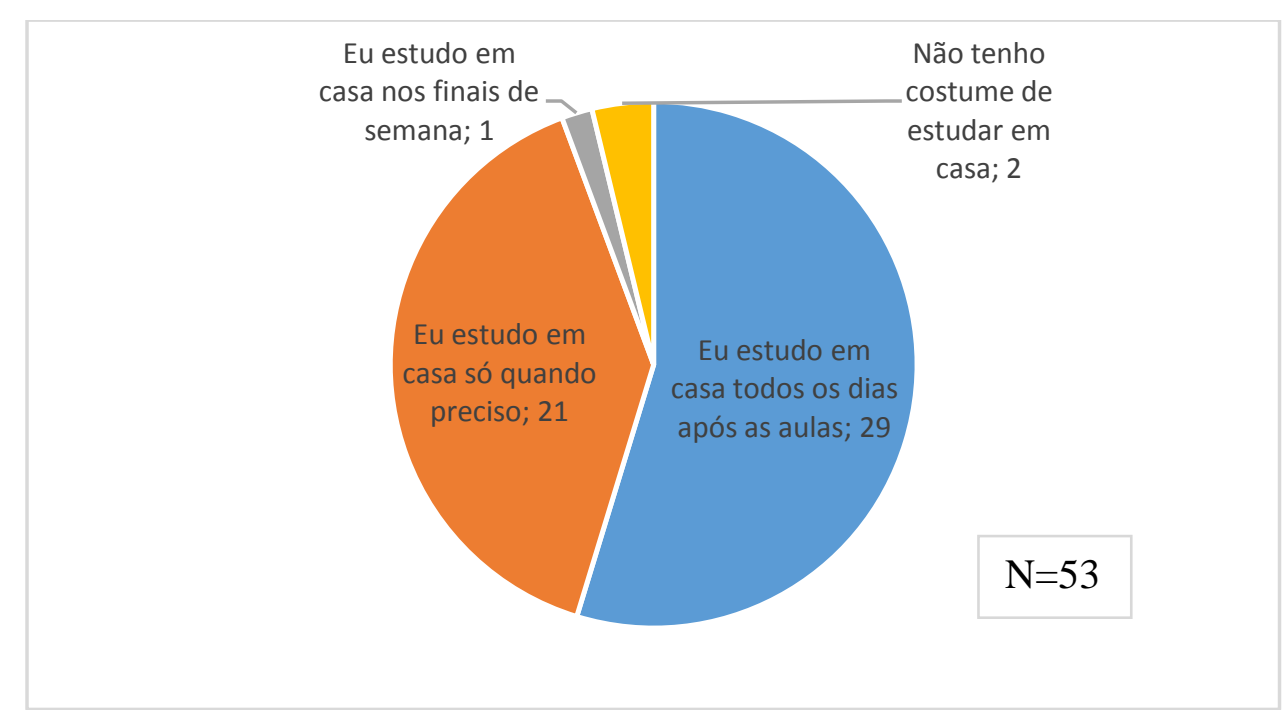

Gráfico 1: Sobre o ato e costume de estudar em casa. 
Em relação aos deveres de casa, o que se soube pelo questionário está apontado no gráfico que segue:

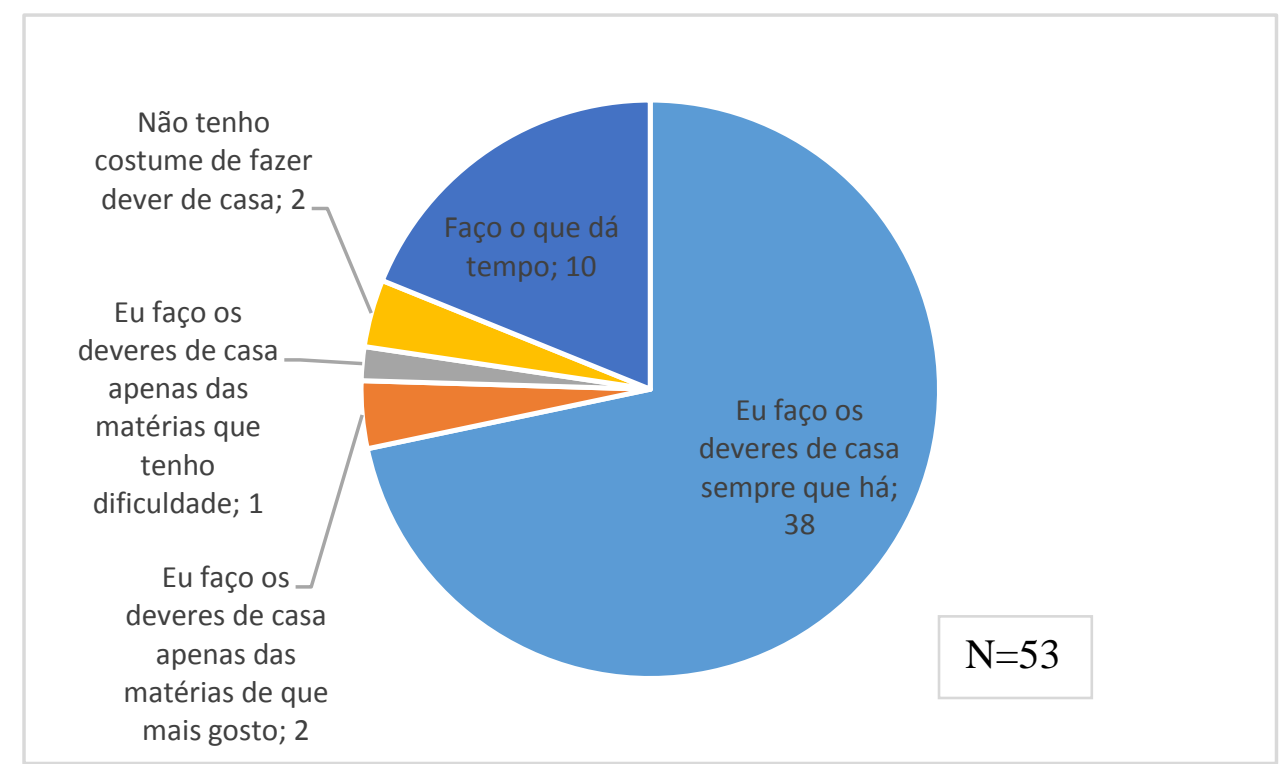

Gráfico 2: Sobre a prática de fazer deveres de casa.

Trinta e oito informaram fazê-los sempre que há o que denota compromisso com a própria aprendizagem. Onze afirmaram que fazem o que dá tempo de fazer. Realmente, muitas vezes, a falta de tempo é um fator concreto. Vários alunos dessa instituição enfrentam diariamente longos percursos entre sua casa e a escola, com horários até desumanos, principalmente quando pensamos que se trata de crianças. Relevante destacar ainda que, ao final do ano letivo, cinco dentre esses onze ficaram reprovados. Dois disseram só fazerem os deveres das matérias de que gostam, o que reforça a ideia de que o interesse do aluno é fundamental para seu aprendizado. Um deles também ficou reprovado ao final. A aluna que afirmou só fazer os deveres das matérias em que tinha dificuldade já vinha de uma reprovação anterior na mesma instituição e acabou sendo jubilada no final de 2014. Isso me faz crer na importância de um processo de ensino e aprendizagem interessante e significativo para o estudante.

Numa questão sobre leitura, o questionário apontou um gosto pelos livros bem maior do que o desinteresse. Entretanto, o reconhecimento dos que dizem não gostar de ler fez-me ratificar em minha formação a importância da sedução do leitor por meio de momentos de leitura em voz alta de trechos marcantes do livro na sala de aula para gerar curiosidade e vontade de desvendar aquelas páginas. 


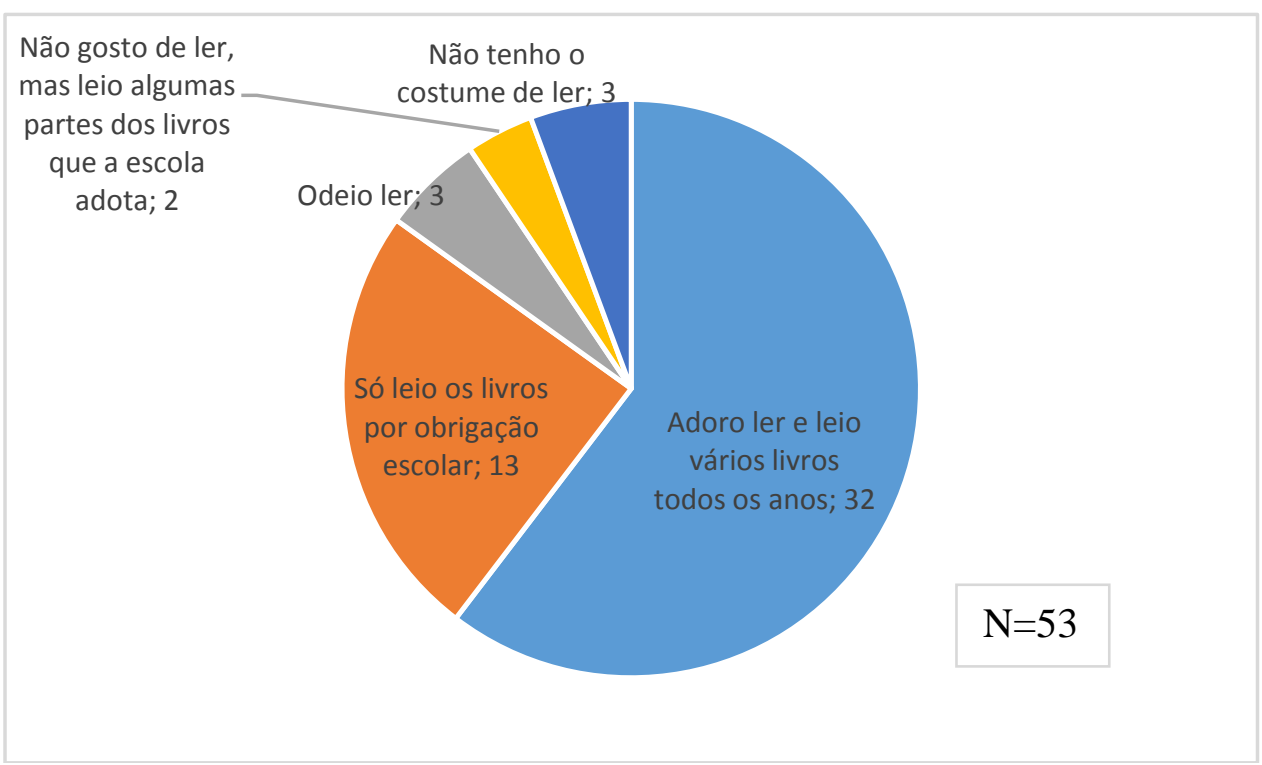

Gráfico 3: Sobre o hábito de ler.

Os trinta e dois que afirmaram adorar ler e que leem vários livros todos os anos ratificam também a existência facilmente percebida no colégio de um grupo de alunos leitores vorazes dessas sagas que consquistaram os adolescentes ${ }^{20}$. Vejo-os há anos lendo muito e sempre andando com "tijolos" em suas mochilas para lerem nosmomentos em que tenham alguma folga. Faço-me sempre a pergunta: por que e como transformamos a leitura em algo negativo, desinteressante para tantos alunos no decorrer de sua vida escolar?

Outra questão que considerei importante para a pesquisa é a que avaliou a percepção do aluno quanto à sua produção textual. O gráfico mostra os dados do questionário:

\footnotetext{
${ }^{20}$ Como as séries Harry Potter, Percy Jackson, Crepúsculo, Jogos Vorazes entre diversos outros.
} 


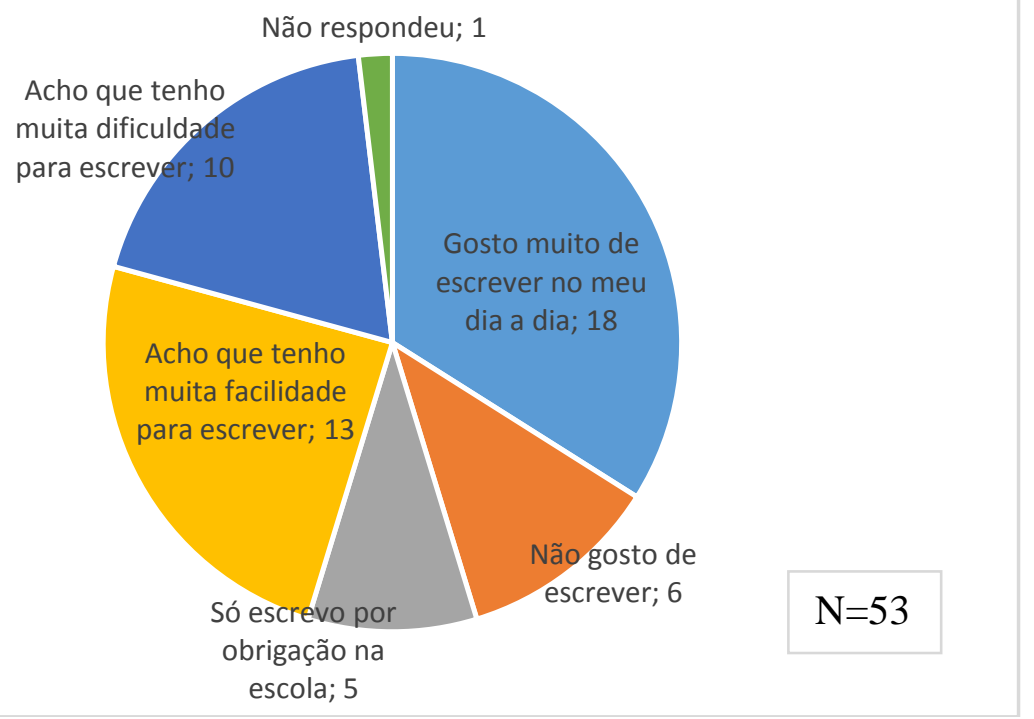

Gráfico 4: Percepção do aluno quanto à sua produção escrita.

Somando os dezoito que dizem gostar de escrever com os treze que acham ter facilidade para isso, encontramos trinta e um alunos com uma visão positiva da produção escrita. Percebo nesse número, que representa mais da metade dos autores desta pesquisa, um alerta para a escola: estamos inibindo a comunicação dessas crianças por meio da modalidade escrita, ressaltando seus erros numa visão de incapacidade e menos-valia? Estamos limitando a criatividade delas proibindolhes de falar e escrever com liberdade e, consequentemente, expressividade, para falar e escrever somente de acordo com os parâmetros exigidos em cada gênero textual, em cada avaliação, em cada situação específica?

Numa pergunta, com subitens, sobre a noção que o aluno tem a respeito das produções textuais que faz na escola, o que se soube pelo questionário está apresentado no gráfico abaixo: 


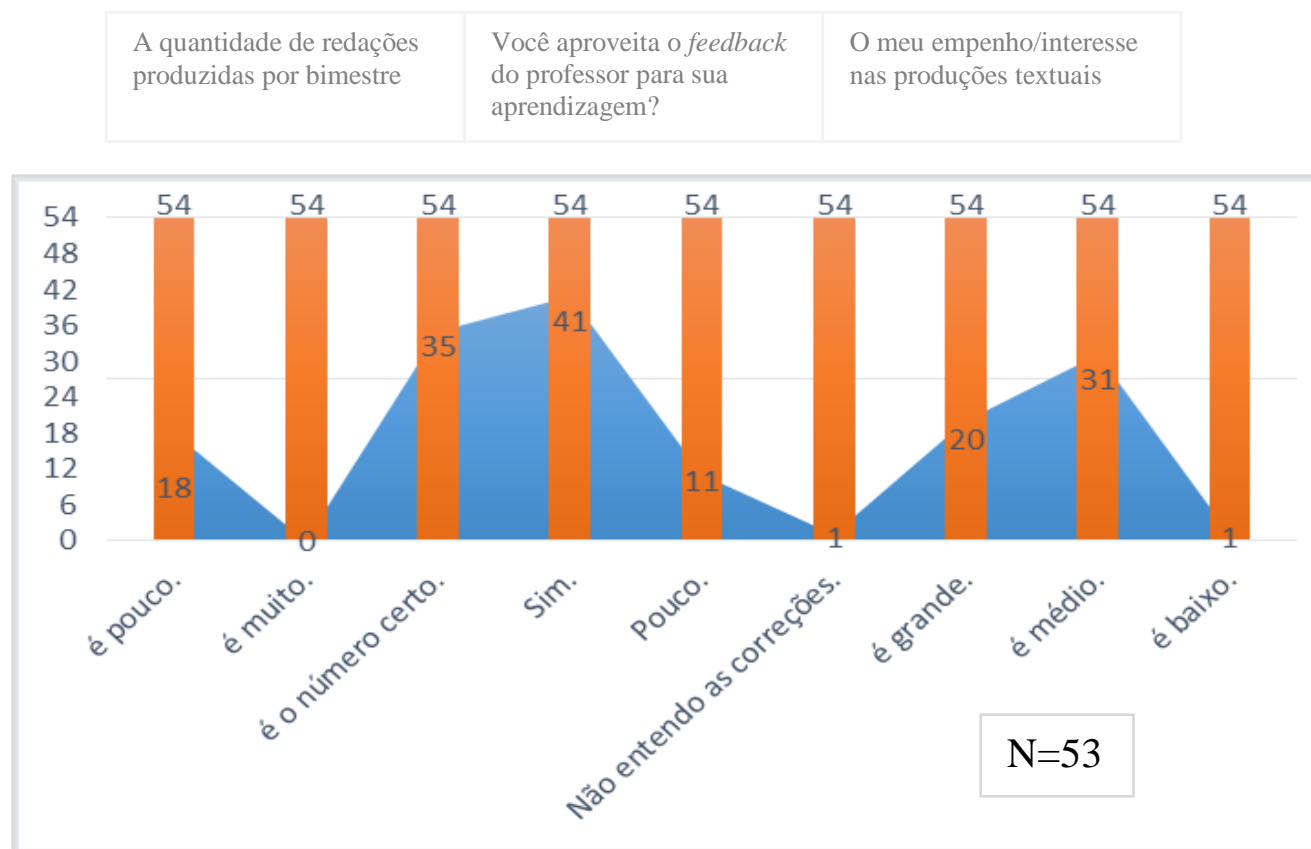

Gráfico 5: Sobre as impressões dos alunos com relação às produções textuais.

Parece-me que esse gráfico apresenta, de certo modo, a realidade da sala de aula. Se produzir, escrever, realizar tarefas e atividades (verdadeiro sentido de "colocar a mão na massa") fossem percebidos pelos alunos como o meio mais eficaz para atingirem o objetivo maior que é a aprendizagem pessoal, talvez uma minoria considerasse o número de redações produzidas no bimestre (duas), insuficiente.

Esses dados foram úteis não só para conhecer as impressões dos alunos sobre suas atuações como estudante, como também serviram como um ponto de partida para avaliar, ao final, a evolução deles na produção escrita. Eu entrei nesta experiência sabendo, por exemplo, que vinte um alunos não gostavam de ler ou o faziam apenas por obrigação escolar e que outros vinte um não gostavam de escrever. Apesar de, em ambas as situações, eles não serem a maioria do grupo de sujeitos da pesquisa, havia ali um desafio a enfrentar. Interessá-los pela leitura e produção escrita. E mais ainda: não desinteressar, com atividades enfadonhas e sem sentido, os que já diziam gostar de ler e escrever.

\subsection{Instrumentos}

Como minha pesquisa se baseou na avaliação contínua de um fazer, explicito aqui os instrumentos da pesquisa e os instrumentos da ação de atividades que realizei ao longo do semestre. São eles: 


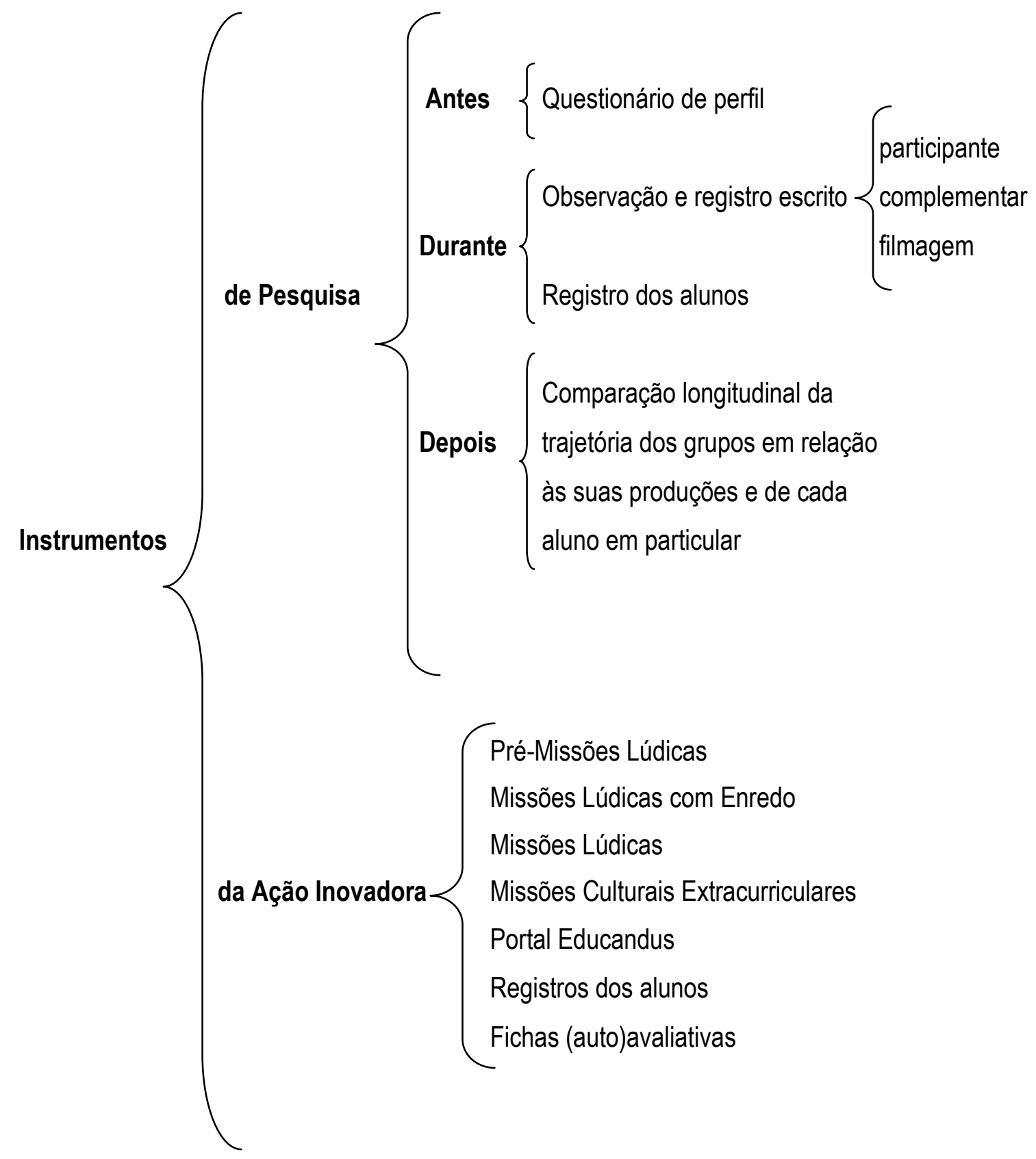

Figura 2: Esquema dos instrumentos de pesquisa e da ação inovadora

\subsubsection{Instrumentos da pesquisa}

Foi realizadano primeiro dia de aula, como já descrito, uma atividade anterior aos procedimentos de ação, mas já engajada na pesquisa: a aplicação do questionário de perfil discente. Tinha como objetivo identificar os hábitos de estudo dos alunos e sua relação com as avaliações (percepção deles sobre eles mesmos). 
Os demais instrumentos de pesquisa foram usados ao longo do processo. São eles:

\section{— Observação e registro escrito}

> Observador Participante

Ao longo do semestre registrei, em um diário de bordo, as dinâmicas de sala de aula e trabalhei para que ele fosseo mais completo possível. As pequenas falhas de registro provêm da enorme demanda de afazeres, tanto das exigências do próprio colégio, quanto do emaranhado de missões a que me dispus criar, promovendo feedback quase que imediato das produções dos alunos.

$>$ Complementar (o amigo-crítico)

Houve também, em algumas aulas aleatórias, a presença da professora Dra.Stella Maria Peixoto de Azevedo Pedrosa, Professora Adjunta do Programa de Pós-Graduação em Educação da UNESA e membro do Grupo de Pesquisa Jovens em Rede do Departamento de Educação da PUC-Rio. Ela se disponibilizou a observar a estratégia, apresentando depois uma avaliação crítica de minhas ações enquanto professora das turmas e sobre o que presenciou nas ações dos alunos.

\section{$>$ Filmagem}

Utilizei também uma filmadora, como instrumento complementar para a coleta de dados, fixa no parapeito da janela em uma posição que pegava apenas parte da turma, por vez, em trabalho. Se por um lado considerei de grande valia para minha revisão, análise e memória de todo o processo, por vezes, considero que atrapalhou a dinâmica da sala de aula, despertando tanto a timidez de alguns quanto a brincadeira de outros que desejavam ser filmados. Além disso, o próprio funcionamento da máquina, no início, fez-me manter a atenção mais nela que na observação da atividade dos alunos, até ter a certeza de que a filmagem estava ocorrendo corretamente.

\section{Registro escrito dos alunos}

Ao longo do semestre os alunos fizeram pequenas redações em um caderno individual criado para isso. Cinco delas objetivaram analisar criticamente as experiências que estavam vivendo com a estratégia usada. 
Estava prevista ainda a possibilidade de realizar grupos focais, o que não foi possível como também o acesso constante e intenso ao Portal de Educação. Apenas um caso de cada um será relatado à frente.

\subsubsection{Instrumentos da ação inovadora}

\section{Atividades}

Dividi toda a dinâmica do semestre em cinco categorias. São elas:

- Pré-Missões Lúdicas:foram todas as atividades que realizei no início do semestre numa experiência lúdica-participativa. Nesse momento eu ainda não sabia, bem ao certo, como articular todas as missões como imaginava ser uma prática lúdica por inteiro.

- Missões Lúdicas com Enredo:são as propostas programadas a partir do momento em que consegui criar uma narrativa ${ }^{21}$ envolvente para o desenvolvimento das dinâmicas interligadas e complementares. Considero parte desse grupo seis missões desenvolvidas no terceiro bimestre.

- Missões Lúdicas:foram todas as atividades seguintes às feitas com enredo, realizadas no terceiro e no quarto bimestres. Elas permaneceram com o caráter lúdico e dinâmico, mas não mantiveram a linha narrativa criada como uma história que costurava as partes. Continham, em contrapartida, um forte caráter participativo e interativo, com uma intensa produção prática por parte dos alunos, com feedback constante de minha parte.

- Missões Culturais Extracurriculares: foram tarefas extras e facultativas, que não foram cumpridas por todos os alunos, mas que me permitiram envolver vários responsáveis no processo de aprendizagem de seus filhos, na construção do conhecimento.

- Atividades Complementares:foram as demais tarefas que fizeram parte das atividades do semestre, utilizando tempos de aula, como as autoavaliações, a aplicação do questionário, algumas aulas em formato tradicional. Elas não continham uma dinâmica diferenciada.

\footnotetext{
${ }^{21}$ Chamo aqui de "narrativa" a construção de uma história, previamente elaborada por mim, que conduziu essas atividades, criando, assim o "círculo mágico".
} 
Como forma de ilustrar o processo e para facilitar o entendimento, apresento, no quadro abaixo, em leitura com sentido anti-horário, as categorias com todas as atividades realizadas em ordem cronológica. Lembro que o primeiro bimestre da pesquisa já era o terceiro do ano letivo e, consequentemente, o último bimestre da investigação foi o quarto bimestre do ano letivo. 


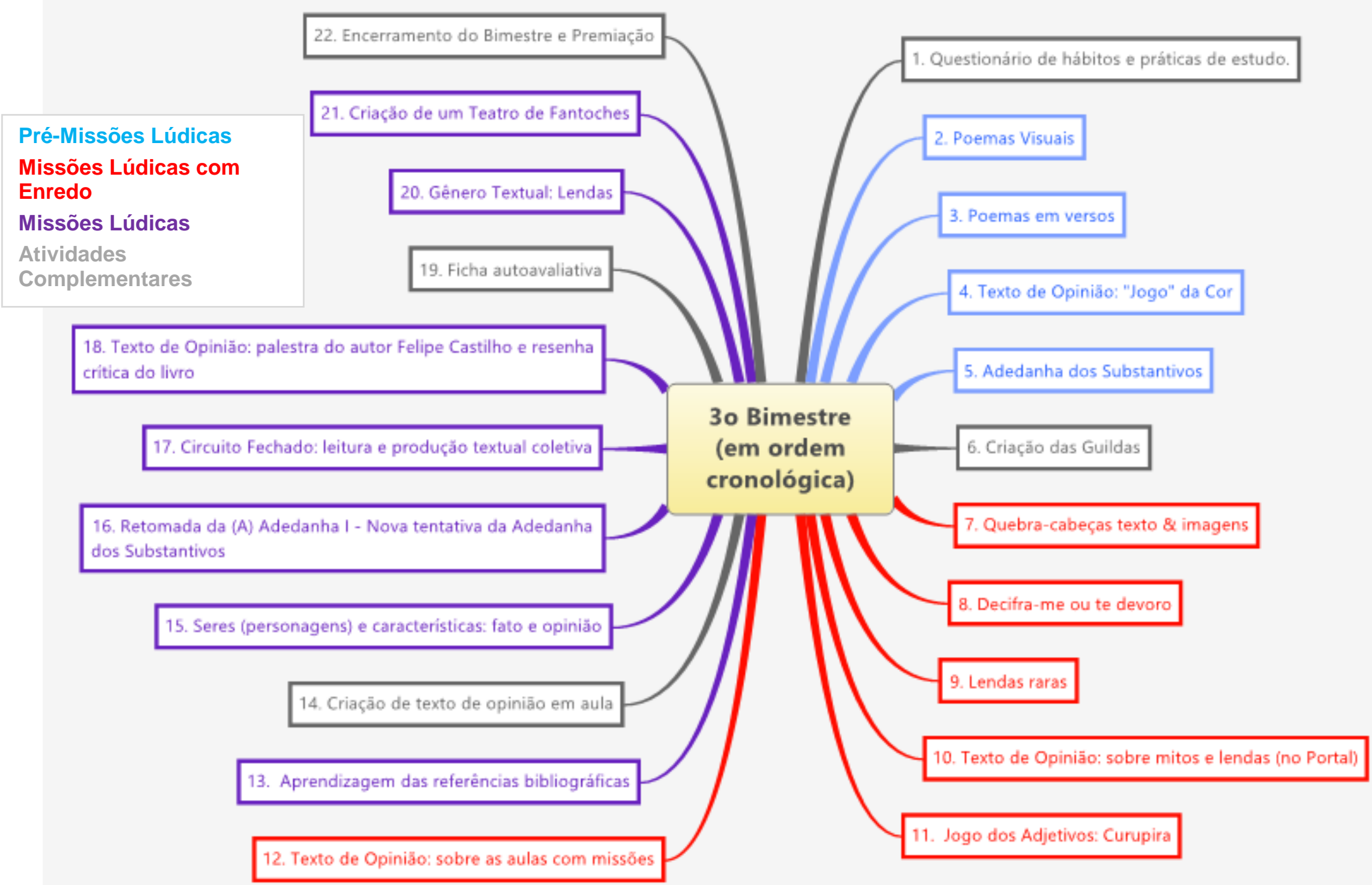

Quadro 1: Panorama geral das atividades propostas (terceiro bimestre do ano letivo de 2014, primeiro período da pesquisa) 


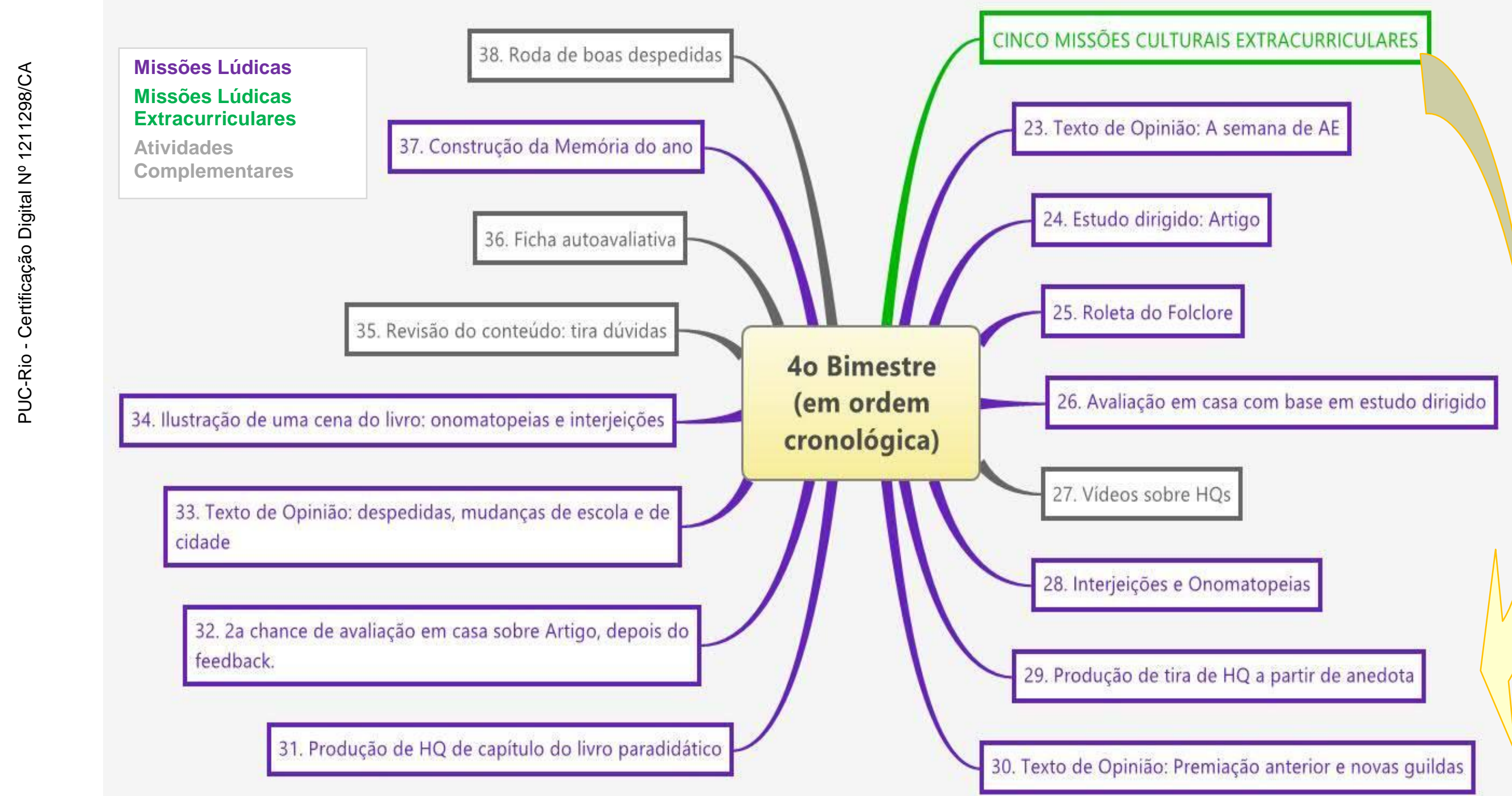

Quadro 2: Panorama geral das atividades propostas (quarto bimestre do ano letivo de 2014, segundo período da pesquisa). 


\section{Registro dos alunos}

Os alunos contaram com um caderno desde o início do segundo semestre nos quais eles realizaram algumas produções textuais contendo suas opiniões acerca das atividades que vínhamos desenvolvendo. Ao final do ano letivo, pedi a eles que deixassem os cadernos comigo para a realização de minha pesquisa, prometendo-lhes devolvê-los assim que terminasse as análises. Eles ainda estão em meu poder e os devolverei até junho de 2016. Recebi quarenta e um cadernos do total de cinquenta e quatro alunos.

\section{Ficha (Auto)avaliativa}

Além de ter dado aos alunos o direito e a chance de opinarem e argumentarem sobre as atividades propostas e realizadas ao longo do semestre, registrando tudo isso em seu caderno, considerei importante também que eles tivessem a oportunidade de, enxergando todas as atividades propostas em cada bimestre, avaliar a própria participação e envolvimento no processo de ensino e aprendizagem. Considerei as duas atividades que realizamos no final de cada bimestre positivas, primeiro pela oportunidade de o aluno aprender a se autoavaliar (a ficha continha uma parte direta, fechada e objetiva e outra parte aberta à opinião e visão do aluno), segundo para que ele tivesse uma noção do todo, isto é, de tudo o que havia se construído para sua aprendizagem. Além das autoavaliações de final de bimestre, uma terceira atividade semelhante foi feita, para que eu pudesse conhecer a produção deles em grupo na criação do teatro de fantoches. (Tais fichas estão expostas nos anexos 3, 4 e 5.)

\subsection{Procedimentos}

Recebi permissão para a realização de minha pesquisa e, na primeira semana após o recesso, apresentei aos professores do $6^{\circ}$ ano, à Supervisora e à chefe da Divisão de Ensino o trabalho que seria desenvolvido nas duas turmas. Igualmente na primeira aula, em cada turma, apliquei o Questionário de Perfil, já relatado no item 3.3, "Sujeitos da pesquisa", a todos os alunos presentes (cinquenta e três ao todo). De início, os alunos questionaram quem leria o que eles iriam escrever, mas lhes garanti que apenas eu faria isso, a fim de tentar aprimorar meu trabalho para 
com eles e de desenvolver a minha pesquisa (expliquei a eles minha proposta de trabalho e minha pesquisa para obter o título de doutora).

Após isso, já começamos os primeiros conteúdos com as propostas lúdicas e com dinâmicas diferenciadas. Nesse trabalho investigativo, eu era a condutora do processo, como professora de Língua Portuguesa das turmas, e observadoraparticipante. $\mathrm{O}$ fato de ter sido professora do grupo da pesquisa não foi um agente complicador. Muito consciente dessa questão, me acerquei de dialogar sempre sobre o processo. A conversa constante com minha orientadora e a troca com colegas do grupo de pesquisa e com alguns professores também pesquisadores do próprio colégio foram necessárias para que eu garantisse o afastamento suficientemente bom para que a experiência implantada e sua avaliação pudessem manter um distanciamento adequado. Fui, assim, uma pesquisadora-condutoraobservadora-participante de um projeto inovador (pelo menos na escola em que atuo), porque estive todo o tempo presente, atuando e observando, promovendo as atividades para os autores e interagindo com eles.

Além desse contato humano de troca, tomei outros cuidados para que o processo fosse o mais possível controlado, no sentido de não me deixar trair pela minha subjetividade. Por isso, para contrabalançar com meu Diário de Bordo, no qual relatava tudo o que acontecia e percebia nas aulas, na maioria das vezes, logo após o término das mesmas, apoiei-me nas gravações em vídeos que fiz durante as atividades, em algumas observações complementares da Professora Doutora Stella Maria Peixoto de Azevedo Pedrosa, membro docente da UNESA, que assistiu a quatro dias de aulas com dois tempos em cada turma e nas opiniões expressas pelos alunos, no que eles escreviam em algumas atividades de produção de texto de opinião.

Simultaneamente elaborava materiais novos para cada nova missão e, nesse ir e vir de experiências e autoavaliações de minha conduta e do desenvolvimento dos alunos, novas missões eram criadas também com o fim de suprir lacunas nas aprendizagens dos alunos.

Todo material que era possível guardar para posterior análise, eu guardava. Algumas produções eram fotografadas; outras eu pedia a um ou a outro aluno que fizesse uma cópia para deixar comigo. Ao final do ano letivo havia juntado um bom corpo de produções desses sujeitos-autores. 
Embora tenha feito várias intervenções durante o processo, procurei promover a todo instante a autonomia dos autores, levando em consideração a noção de autogoverno piagetiana, em que o professor não deixa o aluno solto, no sentido pleno da palavra, para traçar seu caminho. O professor promove a autonomia tendo consciência do objetivo que se pretende alcançar e, dessa forma, oferece as condições necessárias para que o aluno descubra seus caminhos e, consequentemente, seu papel na sociedade e no processo de sua formação. Por isso, me vali do lúdico e do dinamismo da sala de aula para conquistar o interesse e a participação real e ativa dos alunos.

\subsubsection{Procedimentos da Ação}

A maior parte das atividades de LP, durante a estratégia, ocorreu com os alunos reunidos em grupos distribuídos pela sala de aula, distinguindo-se visualmente - e de forma logo percebida e comentada pelos próprios alunos - de como havia sido no semestre anterior. Nas primeiras três semanas, período das Pré-Missões Lúdicas, os grupos foram formados pelas fileiras em que se sentavam; depois organizamos grupos com escolhas semidirecionadas que duraram todo o terceiro bimestre ${ }^{22}$. No quarto, outros grupos foram formados seguindo o mesmo critério de criação.

Além da mudança na distribuição dos alunos no espaço, passei o segundo semestre inteiro criando aulas ativas, interativas, participativas, movidas por tarefas, atividades e missões a cumprir, ao contrário do formato a que eu mesma estava acostumada e no qual fui formada e em que vejo também boa parte de meus colegas atuando. Minha meta era o lúdico, a fim de conquistar o interesse do aluno e colocá-lo ativo no processo de ensino e aprendizagem.

Apesar de ter desenvolvido uma ação fora dos cânones da escola, em nenhum momento me furtei ao fato de estar inserida em uma instituição que apresenta suas exigências e atividades gerais bem especificadas. Por isso, toda a construção da estratégia se baseou, primeiramente, no Plano de Sequência Didática de Língua Portuguesa (PSD-LP), documento do SCMB que contém o programa que deve ser trabalhado no ano, com as habilidades e competências a

\footnotetext{
${ }^{22} \mathrm{~A}$ formação dos grupos a que chamamos de guildas está descrita a seguir, na página 66.
} 
serem desenvolvidas, e o Plano de Execução Didática (PED), produzido pela Coordenadora de Língua Portuguesa do $6^{\circ}$ ano do CMRJ, prevendo o que seria ministrado em cada período, de acordo com o calendário e o material didático disponível. A partir disso, elaborei as atividades e missões, com base, também, nas leituras do bimestre que eram gerais do ano.

Um dos primeiros pontos fundamentais dessa estratégia lúdica era apostar no potencial do aluno. Meu objetivo era transformá-lo, na prática, em autor de sua aprendizagem. Por isso, acreditava que tinha de lhe proporcionar oportunidades de "aprender com seus erros" (papel exercido pelo constante feedback) e desenvolver a capacidade de antecipação das condutas, competência extremamente válida e benéfica. Aliás, tomei o feedback como um dos elementos fortemente presentes nos jogos clássicos de videogame como um dos pontos mais fortes de minha estratégia. Acreditava que se eu promovesse dinâmicas em que os alunos tivessem espaço e tempo para recuperar, entender seus erros e corrigi-los, isso, por si só já seria uma mudança de paradigma, numa escola de base conteudista e em que falta tempo e espaço para o aluno construir efetivamente suas aprendizagens.

A sala de aula, então, se tornou o nosso "jogo" de aprendizagem em tempo real, diferentemente da sala de aula comum, em que a aula é conduzida quase sempre por uma estrutura monológica. O objetivo era dar ênfase aos resultados positivos da aprendizagem e à compreensão do valor real que o erro tem, já que possibilita ao aluno rever todo o processo realizado e ao professor entender o porquê do erro e descobrir novas ideias que não tinham sido levadas em conta quando planejou suas aulas.

\section{Sobre o Portal Educacional}

O Portal Educandus foi pouco usado porque houve bastantes problemas para o cadastro inicial dos alunos. Utilizei-o, no entanto, para compartilhar vídeos e textos extras para enriquecer a aprendizagem, buscando sempre a expressão da opinião acerca do que liam e do que ouviam. Alguns alunos que conseguiam visualizar as publicações, mas não conseguiam escrever lá, produziram suas opiniões em papel avulso e me mostraram. Considerei esse fato muito interessante, pela vontade de participarem do processo de alguma forma, mesmo não sendo obrigatório, devido às condições de acesso. 


\section{Sobre a ficha (auto)avaliativa}

Foram duas fichas (auto)avaliativas durante o semestre, aplicadas ao final de cada bimestre. Nelas os alunos respondiam a perguntas fechadas sobre a realização ou não das atividades propostas ao longo do período e, depois, respondiam a questões abertas em que podiam expressar livremente a sua opinião a respeito de todo o processo. Essas duas (auto)avaliações foram, por decisão deles, transformadas em pontos (valendo dez) para compor a nota de AP (Avaliação Parcial), cuja média (composição de todos os testes e trabalhos feitos no bimestre) era somada à nota da $\mathrm{AE}$ (Avaliação de Estudo - prova bimestral), para formar a média final daquele período a ser lançada no Boletim do aluno. Essas(auto)avaliações demonstravam muito claramente o que cada aluno havia feito, em que tinha falhado e como esse processo de atuação pessoal era representado em escala de zero a dez.

\section{Sobre a formação das guildas}

Lancei a nova etapa de atividades formando com os alunos as guildas por uma espécie de escolha direcionada. Inicialmente utilizamos a definição de guilda apresentada no livro paradidático adotado em cujo glossário se dizia "Players que se reúnem em um grupo com a finalidade de alcançar os mesmos objetivos. (...)" (CASTILHO, 2013, p. 10). Essa definição era apenas um mote para descobrir o que eles sabiam (e se sabiam) algo sobre o assunto. Os alunos demonstraram domínio sobre o tema, trazendo explicações mais profundas, remetendo o termo à sua criação na Idade Média e exemplificando com as experiências que tinham dos vários jogos de videogame que conheciam. Para uma organização aqui, utilizei a definição que aparece no Dicionário Houaiss da Língua Portuguesa: "associação que agrupava em certos países da Europa durante a Idade Média, indivíduos com interesses comuns (negociantes, artesãos, artistas) e visava proporcionar assistência e proteção aos seus membros". Ela define bem o que os alunos explicaram e assumiram na construção dos novos grupos a que chamamos de guildas.

Indiquei um aluno para "abrir" cada uma das seis guildas (procurei os alunos com as maiores notas em minha disciplina para que eles não se juntassem em um mesmo conjunto e houvesse tendência de homogeneidade nos grupos e disparidade potencial entre as equipes). Em seguida, cada um escolhia um novo 
membro e o membro selecionado fazia a indicação seguinte sucessivamente, até que todas as guildas estivessem com quatro membros cada uma. Ao final, três alunos de cada turma estavam sem grupo. Estes tiveram a chance de decidir em que guilda entrariam (cada um em uma diferente).

Os cinquenta e quatro alunos-autores, então, foram divididos em seis guildas, em cada turma de vinte e sete alunos. Essas guildas, a partir dali, trabalharam em busca da vitória das equipes pela conquista do produto da aprendizagem, numa disputa que se propunha amigável e interessada, mas que objetivava, na verdade, o crescimento de cada indivíduo e dos grupos num processo de cooperação, colaboração e altruísmo. Quando uma missão era cumprida acertadamente eram atribuídos pontos ao aluno ou à guilda, dependendo da situação. Esses pontos acumulados foram usados ao final como fomentador da leitura, pois os próprios alunos pediram que houvesse prêmio para os vencedores. Alguns pais, inclusive, estavam tão empolgados com o que seus filhos lhes contavam, que, na reunião bimestral de responsáveis e professores, ofereceram-se para fazer uma "vaquinha" a fim de contribuir com a compra dos livros. Eu, no entanto, agradeci, mas recusei para não haver nenhum complicador na escola e na pesquisa por envolver dinheiro de aluno. Os membros da guilda vencedora no terceiro bimestre, então, ganharam, cada um, um cartão-presente no valor de trinta e cinco reais de uma livraria na qual poderiam trocar pelo livro que desejassem. Esse prêmio só foi entregue depois que os alunos vencedores levaram uma circular informativa aos responsáveis e a trouxeram assinada com o consentimento deles.

Hoje posso dizer que a premiação incentivou muitos alunos no sentido de despertar ainda mais interesse, mas também fez outros sofrerem bastante. Sendo assim, não sei se, no conjunto da proposta, principalmente em se tratando da faixa etária com a qual trabalhei, isso tenha sido válido. Em verdade, a estrutura que criei para atingir a premiação serviu, de forma concreta, para duas coisas que vão além da premiação em si: a) proporcionar aos alunos, pelo menos inicialmente, uma disputa interessada em um processo de cooperação e colaboração entre colegas para o crescimento de todos dentro de cada guilda (ouso dizer que é por meio da colaboração, troca e cooperação, quando há maturidade para que isso se desenvolva, que se promove um novo tipo de cultura em que os sujeitos se 
engajam e participam ativamente porque estão genuinamente interessados) e b) registrar a progressão e compromisso de cada um nas atividades gerais para que eles tivessem uma noção clara do quanto estavam produzindo e do quanto estavam deixando de fazer para a sua própria aprendizagem no dia a dia. Para mim esse procedimento acabou sendo importante porque auxiliou os alunos na (auto)avaliação, mas hoje percebo que deveria promover esse registro desvinculado de ranking e premiação. Há outros referenciais como a superação de si mesmo e as pequenas vitórias a cada aprendizagem que devem ser valorizados por eles, e não a premiação externa.

Depois de toda a mediação e diálogo para que as guildas fossem formadas, já com as equipes reconhecidas por todos os membros, li dois trechos que selecionei do livro Ouro, Fogo e Megabytes: um sobre ética, ser ético com os colegas (2013, p. 101-102) e outro sobre trabalhar em equipe (2013, p. 252). O objetivo era gerar um bate-papo para levá-los a uma reflexão sobre ética e equipe (grupo, guilda, associação, cooperação e corresponsabilidade); e sobre os compromissos dos membros de uma guilda com as atividades e com os demais membros. Afinal, desenvolvia minha pesquisa também com a convicção de que por meio do trabalho colaborativo entre os alunos é possível criar uma nova cultura de aprendizagem, em que os sujeitos engajados e interessados aprendem melhor.

\section{O livro paradidático adotado}

O livro paradidático escolhido para o terceiro bimestre foi uma indicação de outra professora da série. Eu não o conhecia (era relativamente novo no mercado, lançado em 2012). Chamou-me a atenção o fato de ser uma aventura com um herói brasileiro, mas estilo Harry Potter e Percy Jackson. O personagem é um garoto de doze anos, magro, negro, sem habilidades para esportes, sem facilidade para se relacionar com os ditos "populares" da escola. Tinha, porém, diversas outras habilidades pouco destacadas ou usadas no contexto da escola. Era, por exemplo, um líder nato dentro de uma guilda em um jogo de videogame. Além disso, a história se passa no Brasil e com personagens provindos de nossas lendas, como o Saci, o Curupira, o Boitatá etc.

Conforme fui realizando a leitura desse livro, comecei a entender melhor algumas questões que tinham a ver com a minha proposta inicial de transformação 
das aulas em um processo lúdico e também coletivo: eram latentes, na história, a necessidade do trabalho em equipe, da cooperação e da lealdade para a sobrevivência dos personagens, além da postura ética diante do mundo. Ouro, Fogo \& Megabytes, de Felipe Castilho, então, foi um elemento de grande importância para o desenvolvimento do meu fazer pedagógico porque acabou se tornando um eixo condutor para a produção das atividades lúdicas, dialogando diretamente com os conteúdos de Língua Portuguesa do período.

Aliás, é importante dizer que, em conjunto, a equipe de Língua Portuguesa decidiu adotar no quarto bimestre o volume dois da saga ("O Legado Folclórico": Prata, terra \& lua cheia, de Felipe Castilho), devido ao sucesso que tinha sido o primeiro e do envolvimento e interesse dos alunos com a leitura. Esse é um importante ponto a ser levado em consideração na escolha de um livro de leitura (obrigatória): encontrar histórias que proporcionem experiências positivas de aprendizagem e, ao mesmo tempo, de fruição da leitura.

\section{Levantamento bibliográfico}

Como parte da construção do referencial teórico da pesquisa, foi feito um levantamento bibliográfico no banco de teses e dissertações acadêmicas, no portal BDTD, do Instituto Brasileiro de Informação de Ciência e Tecnologia ${ }^{23}$. Em termos gerais, busquei trabalhos com as palavras ou expressões "lúdico", “ensino", "Língua Portuguesa", "Ensino Fundamental II” e "Ensino Médio", associadas de modos diferentes, sendo que "lúdico" era colocada em todas as opções.

O que percebi, mesmo quando a associação continha a especificação da etapa de ensino da Educação Básica, é que a maioria dos trabalhos produzidos relacionados ao lúdico se referem à Educação Infantil ou ao primeiro segmento do Ensino Fundamental. Os trabalhos encontrados fora desses dois espaços carregam, em grande parte, uma ideia de aproximação do aluno a matérias consideradas difíceis de serem ensinadas/aprendidas, como Matemática, Química e Física, ou se propõem ao uso de ferramentas tecnológicas e de criação de jogos. Ainda aparecem trabalhos com o lúdico nas áreas de Educação Física, Artes, Música e Geografia Espacial, todas com um teor de movimento e de uso do corpo.

\footnotetext{
${ }^{23}<$ http://bdtd.ibict.br/vufind/>
} 
Com exceção das poucas teses e dissertações que cito no corpo de minha fundamentação teórica (capítulo 2), as leituras que fiz do corpus encontrado serviram para me orientar quanto aos autores mais lidos e utilizados quando se quer discutir jogo e lúdico na Educação. Não encontrei trabalho algum com uma proposta diferenciada mais geral para uma mudança da perspectiva escolar.

\section{Avaliação da evolução qualitativa dos alunos}

Como um dos objetivos da estratégia era promover o desenvolvimento qualitativo da expressão da opinião pelo aluno, precisava criar um meio de avaliar essa evolução para verificar a pertinência (ou não) da proposta. Dessa forma, aevolução qualitativa do aluno foi avaliada por mim, levando em conta, além dos aspectos discursivos de capacidade de expressão ${ }^{24}$, a comparação de textos produzidos em momentos distintos da realização da estratégia. Observei a construção textual com os quesitos mínimos necessários para a idade como apresentação, organização de ideias minimamente separadas em períodos e em parágrafos, com uma pontuação adequada e uso de conectivos para coesão textual. Criei um quadro com setas coloridas para que o panorama geral fosse melhor compreendido. Há três possibilidades gerais: o aluno estava aquém do $6^{\circ}$ ano, isto é, apresentava lacunas em sua aprendizagem anterior ao que se espera da criança que chega ao Ensino Fundamental II; o aluno estava no nível adequado, dessa forma, pronto para cursar o $6^{\circ}$ ano; o aluno estava além em sua aprendizagem, ou seja, sua formação intelectual e afetiva, provavelmente, já lhe possibilitariam cursar uma série mais adiantada.

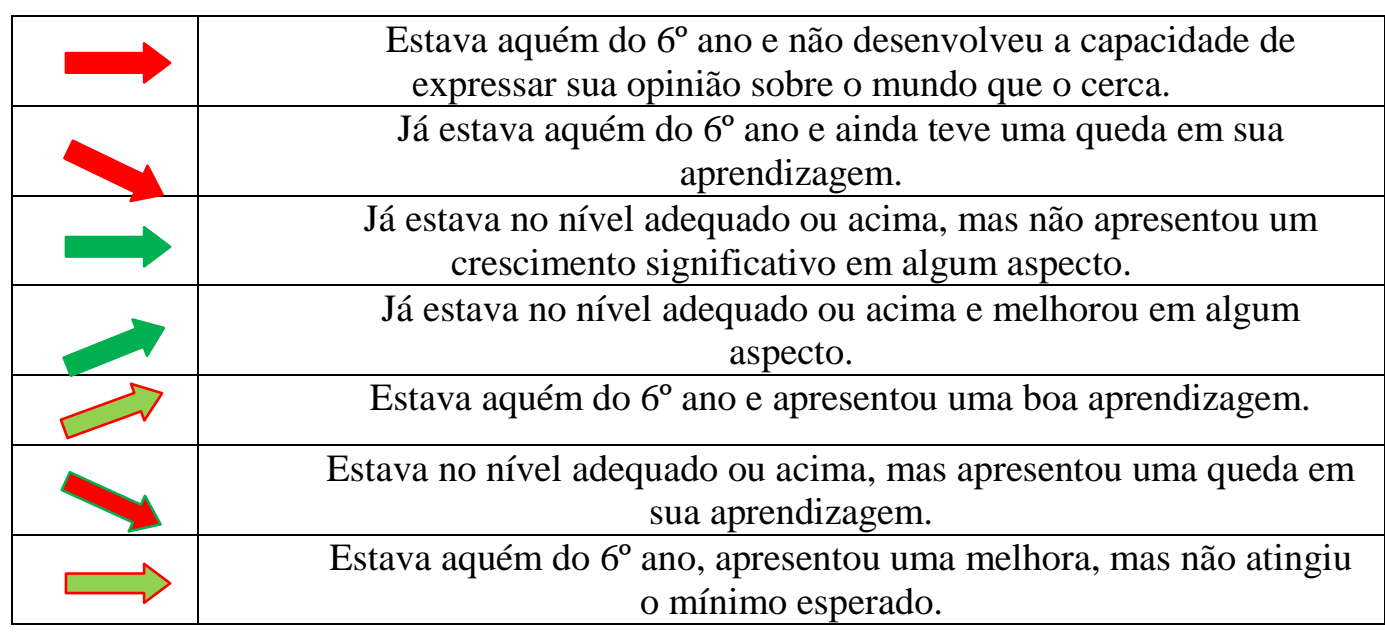

Quadro 3: Código para representar a evolução qualitativa de cada aluno.

\footnotetext{
${ }^{24}$ No capítulo 6, quando trato dessa avaliação, detalho esses aspectos.
} 
Foi com base nesses instrumentos e procedimentos que desenvolvi a minha pesquisa. A necessidade de apontamentos constantes, de (auto)análise no/do processo, de constante interação com alunos, colegas e orientadora para que pudesse acompanhar e coordenar tudo a que me propunha, transformaram, de fato, a proposta inicial em um autoestudo, que me atrevo a dizer, bastante relevante para a reflexão docente sobre nossas práticas. 


\section{A implantação da experiência: primeiro período da pesquisa( $3^{\circ}$. bimestre do ano letivo)}

As atividades que foram desenvolvidas ao longo do terceiro bimestre de 2014 são o cerne deste capítulo, no qual relato de forma clara e mais objetivamente possível a aplicação e desenvolvimento de cada uma das "missões" planejadas por mim, para o desenrolar desta pesquisa. A discussão dos dados e os desdobramentos do processo não são os objetivos deste capítulo, embora em algumas situações já haja um prenúncio.

\subsection{Conteúdo Parcial de Língua Portuguesa para o 60 ano do Ensino Fundamental}

A estratégia que desenvolvi durante o terceiro e quarto bimestres letivos de 2014 tinha de acompanhar e cumprir o programa geral do SCMB segundo o Plano de Sequências Didáticas (PSD), com todos os conteúdos a serem trabalhados em cada ano. O quadro abaixo ilustra a estrutura do documento que apresenta a Matriz de Referência da Área de Linguagens, Códigos e suas Tecnologias (as competências e habilidades) com a indicação dos objetos de conhecimento (conteúdos) a serem trabalhados nas práticas de escuta e leitura, produção de textos e análise linguística. 


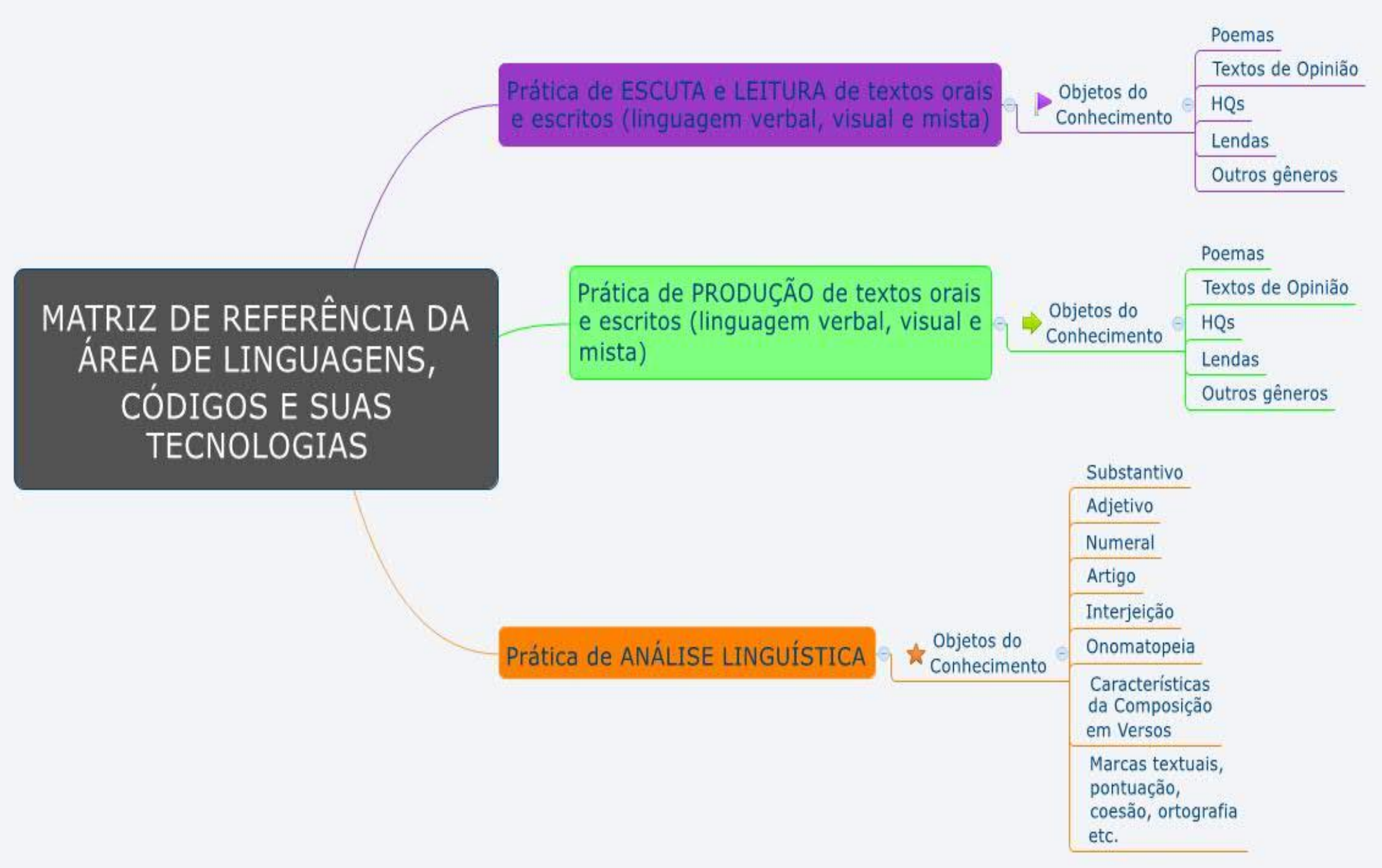

Quadro 4: Conteúdo de LP para o $3^{\circ}$ e $4^{\circ}$ bimestres letivos do $6^{\circ}$ ano do EF 
Foi a partir desse quadro que produzi as conexões entre os objetos de conhecimento e cada uma das práticas da estratégia utilizada.

\subsubsection{Pré-missões lúdicas: o início de uma mudança}

O período chamado "Pré-Missões Lúdicas" foi uma etapa de adaptação ao novo, com tentativas e experiências de uma nova estratégia que estava se construindo na prática. No início do semestre, formulei propostas lúdicas para trabalhar determinados conteúdos, sempre com o objetivo de gerar produção e ação por parte dos alunos. Essas construções, porém, ainda não atingiam, em minha primeira análise, o que era o meu objetivo: missões que contivessem, em sua estrutura, elementos de jogos,essenciais para uma experiência totalmente lúdica em todas as atividades e propostas. Entendia o que estava fazendo como aulas apenas mais animadas e participativas. Esse momento inicial, no entanto, resultou num trabalho bem interessante e com grande participação dos alunos como se eles estivessem carecendo de algo diferente daquela rotina entediante. Isso, por si só, já tomou um rumo positivo a meu ver, pois a vontade de os alunos estarem nos tempos de LP, a alegria com que me recebiam na porta da sala para entrar e a expectativa que demonstravam ter das aulas seguintes, quando me encontravam nos corredores e me abraçavam pedindo que lhes desse aula naquele tempo, eram evidentes e contagiantes.

Apresento abaixo um quadro com uma visão geral do que foi esse momento. 


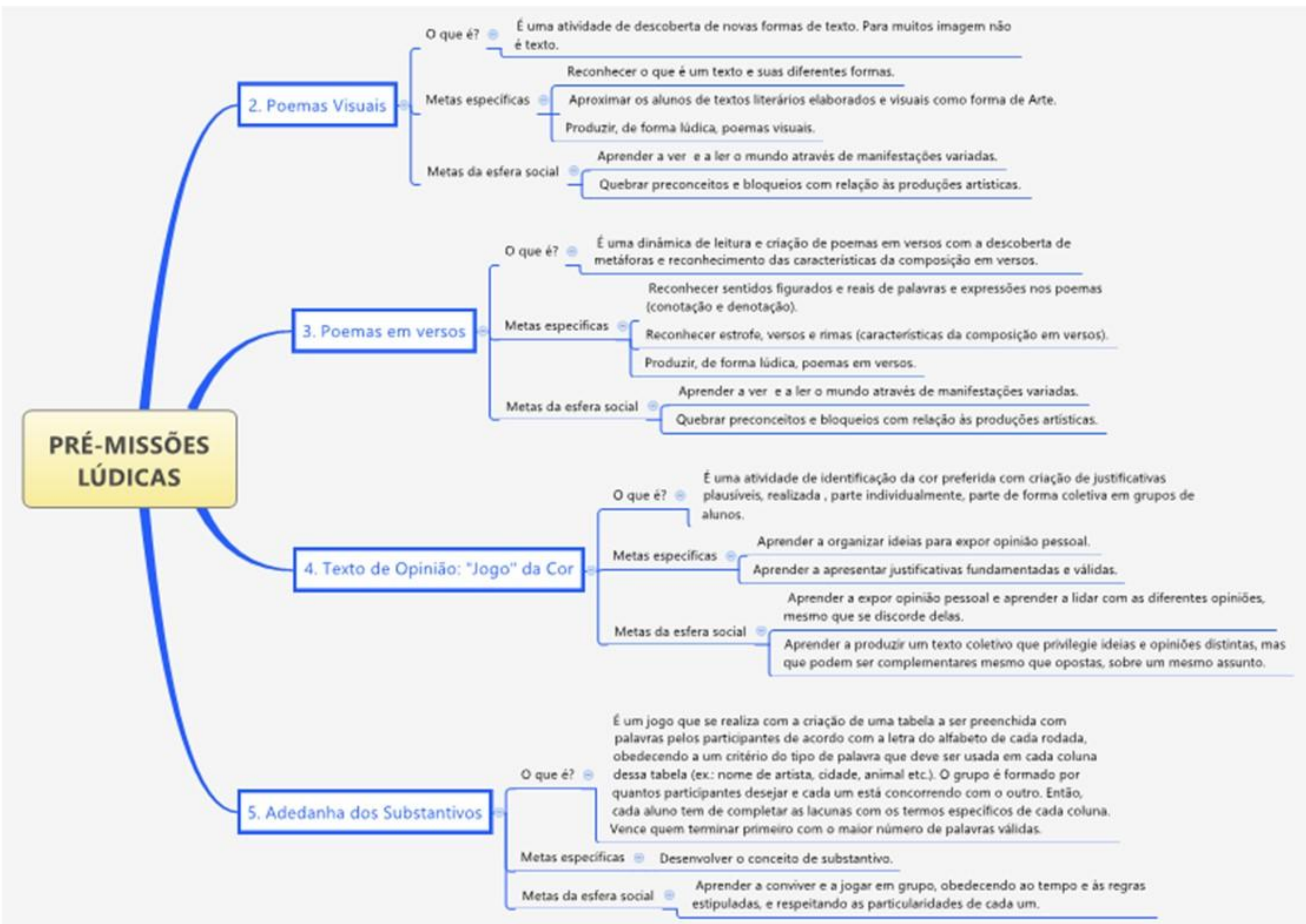

Quadro 5: Panorama geral das pré-missões lúdicas com quadro explicativo. 
Esse período se desenvolveu ao longo das três primeiras semanas do segundo semestre, incluindo uma visita de todo o ano ao Museu Casa do Pontal. Nele, foram realizadas quatro atividades programadas (abaixo destacadas), mais uma atividade livre (livre porque se valia apenas da minha curiosidade. Poderia fazer quem quisesse, mas acabou dando início à expressão de opinião, que será apresentada nas discussões sobre os textos de opinião). As quatro atividades são:

- a aproximação deles aos poemas visuais;

- a leitura e reconhecimento de características dos poemas em versos;

- o desenvolvimento da capacidade de expressar opinião sobre algo ao seu redor (atividade sobre a cor preferida) e

- o reconhecimento dos substantivos.

E a atividade livre:

- desenvolvimento da capacidade de expressar opinião sobre o tipo de poema que mais havia gostado.

Ao final foram criadas as guildas que deram início a uma nova etapa.

As quatro atividades eram independentes entre si, mas algumas se interrelacionavam. Por exemplo, o trabalho com poemas, sejam eles visuais ou em versos métricos ou livres, formam um conjunto maior desse gênero textual. Então, houve certa continuidade até mesmo para o trabalho de leitura e entendimento com base nas metáforas e escolhas lexicais.

Essas duas atividades juntas geraram uma possibilidade de expressão da primeira opinião. Pedi informalmente aos alunos que escolhessem um dos dois estilos de poema e dissessem o que lhes agradava mais, apresentando justificativas. Foi com essa atividade livre que dei início à expressão de opinião para o desenvolvimento do trabalho que seria feito ao longo do semestre.

Estava muito preocupada, desde o início, com o material elaborado para entregar aos alunos. Como considerava importante conquistar o interesse deles em todos os sentidos para as aulas, procurei promover isso por meio das apresentações dinâmicas, da beleza do material, sempre colorido (a impressão e/ou a própria folha de papel), dos textos pequenos inicialmente para não gerar desânimo nem preguiça para ler, mas repletos de significado.

A leitura de poemas diversos foi seguida de um "brincar de poesia": foram feitas produções individuais de poemas visuais 


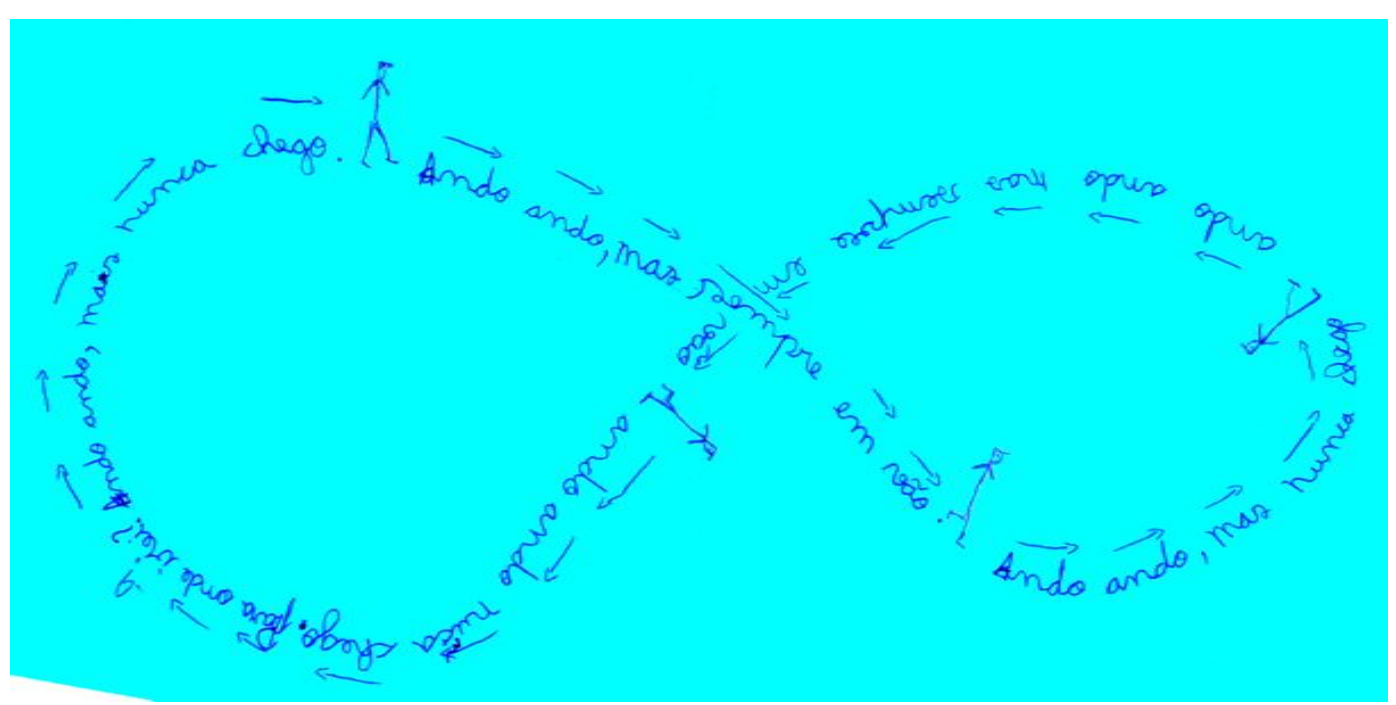

Figura 3: Poema visual de AutorA12

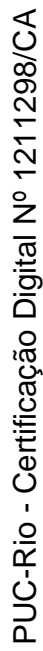

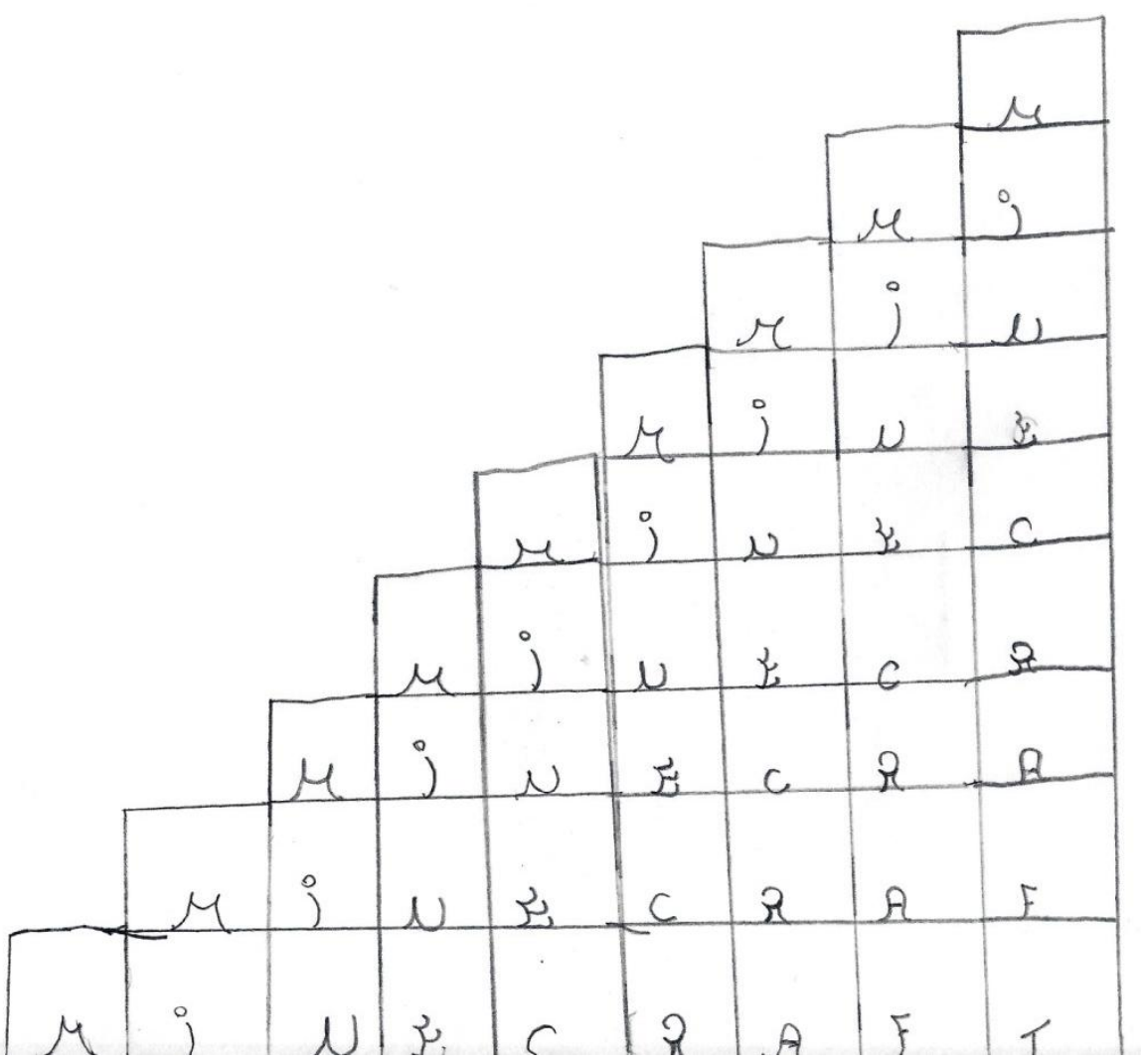

Figura 4: Poema visual de AutorA3e de poemas em versos a partir de rimas criadas entre colegas. 
Inconstitucionalicionamente
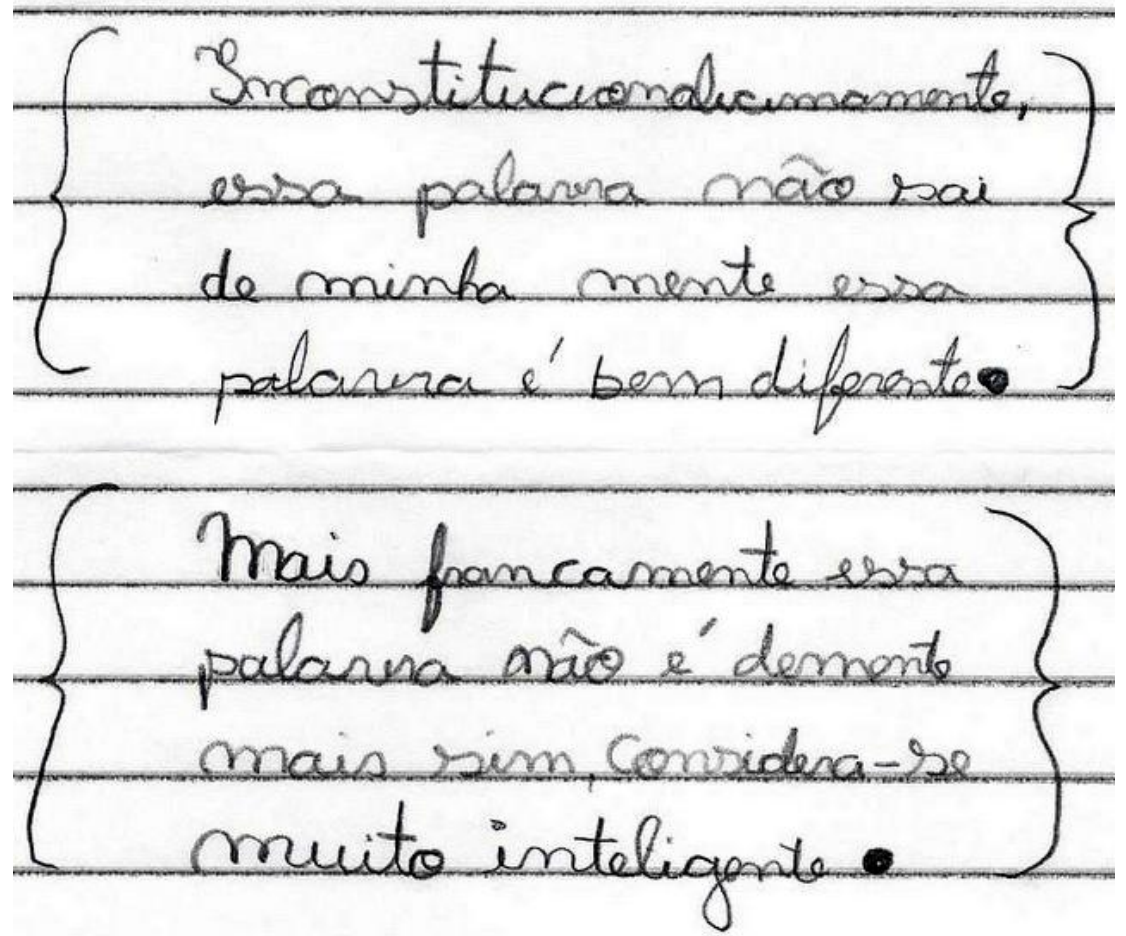

Figura 5: Poema visual de AutorB15

No selégu militar

devo one preacupar

com farda arrumado

e tudo no lugar.

Todos os dias na porta

Do cuiforme tem unosperar

Se perco a plaqueta

ganho una punicaro.

Figura 6: Poema visual de AutorA46 


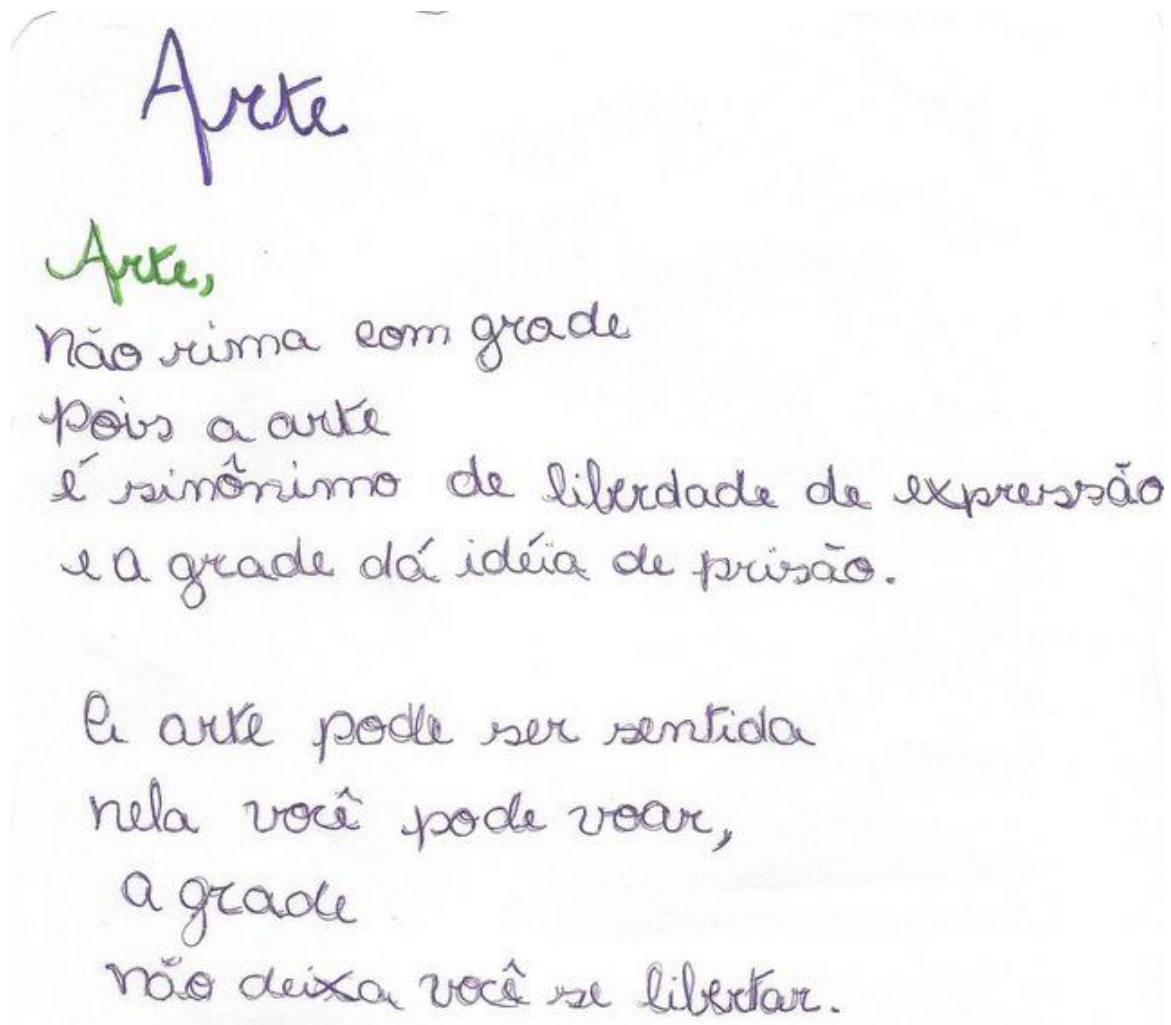

Figura 7: Poema de AutorB54

Conforme recebia os poemas produzidos por eles, lia-os e lhes dava feedback exaltando a criatividade na mesma aula. No entanto, levei todos para uma leitura mais criteriosa em casa, a fim de lhes dar um feedback mais detalhado sempre na aula imediatamente seguinte, com o objetivo de reescritura.

Na sequência, após termos lido vários poemas de poetas renomados e suas próprias criações, "joguei” como ideia escreverem um pequeno texto em que apontassem, com base nas diversas leituras feitas em sala, que tipo de poema eles tinham mais gostado: os visuais ou os em versos, e o que estavam achando das atividades realizadas.

Essa proposta bem informal, mas que foi realizada pela grande maioria, deu início a um conteúdo que procurei desenvolver ao longo de todo o segundo semestre. Na prática que temos há anos (faço uma crítica a um trabalho geral comum diante da quantidade de conteúdos a serem ministrados nas diversas disciplinas, embora tenha conhecimento de realizações maravilhosas de alguns colegas), o gênero, nesse caso, texto de opinião seria apresentado ao aluno, com suas características e estrutura, ele teria de fazer uma redação sobre uma leitura ou 
um filme e culminaria com o recebimento da nota pela produção, não tendo, na maioria das vezes, a oportunidade de vivenciar por muito tempo esse gênero até que chegasse a outro ano que o "cobrasse" também. Por discordar desse processo comum, tomei como ponto fundamental do conteúdo desse semestre e de minhas aulas, com a nova proposta de trabalho, o desenvolvimento semanal da capacidade de expressar opinião e apresentar argumentos para validar o ponto de vista (isso foi feito apenas nas duas turmas em que eu lecionava). Não posso deixar de destacar que essa produção textual intensa, nesse caso específico, ajudou não somente a eles na aprendizagem da disciplina Língua Portuguesa (que, acredito, afetará também outras áreas de sua formação), mas também a mim, com suas críticas ao meu trabalho.

Depois dessa primeira tentativa para a expressão da opinião a respeito do tipo de poema que tinham mais gostado, com interação efeedback, resolvi buscar a construção da opinião com algo mais concreto para eles. A criança de sexto ano precisa aprender a expressar o seu pensamento, os seus sentimentos sobre o que vê e vive. Ela precisa organizar as ideias que vêm à cabeça sobre um assunto, para conseguir formular perguntas e afirmações. E mais, o aluno dessa idade precisa descobrir-se ou enxergar-se como alguém que pode apresentar uma opinião relevante sobre algo a partir do desenvolvimento do que viu, do que gosta etc. É nesse sentido que trato aqui Texto de Opinião. $\mathrm{O}$ que se pretende desenvolver numa série inicial como essa é que eles tenham condições de se colocar, de se expressar, de se posicionar em relação ao que está ao redor deles, ao que faz parte da vida deles. O trabalho, então, se baseia na construção e no desenvolvimento da expressão de opinião a partir de assuntos e pontos do dia a dia do aluno.

Busquei, então, a tal concretude para uma produção textual mais consistente e consciente, criando como tema algo que fosse palpável e comum a eles. Utilizei, então, um assunto que sempre me chamou atenção em relação às regras do colégio: a cor favorita. Normalmente, nessa idade, as crianças gostam muito de escolher roupas e objetos de uso com base nas cores de que tanto gostam, principalmente as meninas. No CMRJ, no entanto, é difícil desenvolver/enxergar um aspecto dessa identidade e singularidade já que o uniforme imposto atinge não só a roupa e sapatos, como também a utilização apenas da cor preta para mochilas, lancheiras, fichários, elástico de cabelo, no caso das meninas etc. 


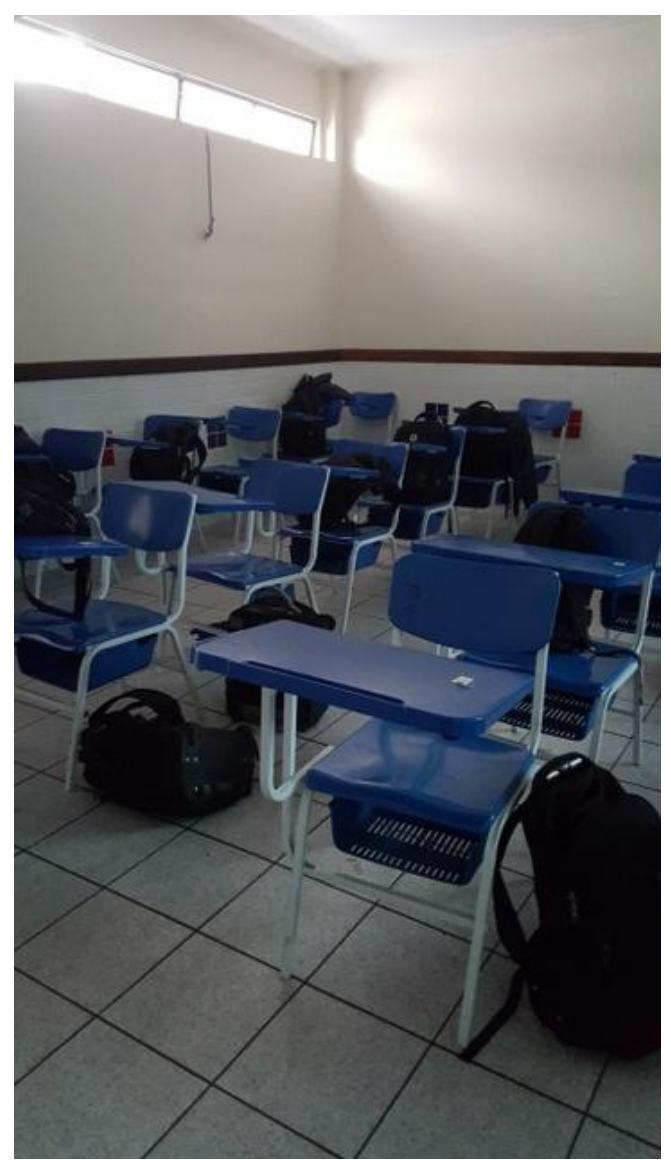

Foto 3: Mochilas igualmente pretas de alunos do $6^{\circ}$ ano do EF.

O "jogo" da cor ${ }^{25}$, então, consistiu em duas etapas, uma individual e outra coletiva. Na primeira, cada aluno deveria escrever em um papel qual a sua cor favorita, apresentando justificativas para essa escolha. Na segunda, os alunos se juntaram pelas cores para a produção de um texto único. A proposta inicial desse trabalho era, em um primeiro momento, criar uma situação real para que pudessem expressar sua opinião. Num segundo momento, o trabalho coletivo geraria uma oportunidade para que eles pudessem não só aprender a expor sua opinião para os outros, como também que pudessem aprender a lidar com as diferentes opiniões, mesmo discordando delas. Além disso, o desenvolvimento de um trabalho em grupo exige um cuidado com o coletivo nas escolhas, na apresentação do produto, na dedicação e responsabilidade de cada membro.

Iniciando a atividade, assim que todos terminaram a escolha da cor e a escrita da justificativa, me dirigi a um aluno qualquer e perguntei que cor havia escolhido, chamando, em seguida, todos os demais que tivessem apontado a

\footnotetext{
${ }^{25}$ Não foi um jogo, mas, inicialmente, dei esse nome (hoje vejo que de forma errada) porque ainda
} estava tentando criar aulas numa estrutura gamificada. 
mesma cor. Na frente da sala, cada um leu a sua justificativa para a turma, que, ao término, votaria nas opiniões mais interessantes. O mesmo foi feito com todas as cores distintas escolhidas por eles.

Durante a dinâmica, precisei interagir com todos para mantê-los, sobretudo, respeitosos para com os colegas, já que, como mencionei acima, eu ia interagindo e levantando questões sobre a quantidade, a qualidade e o "peso" dos argumentos apresentados. Pedi, então, como tarefa de casa, que reescrevessem seus textinhos de opinião, observando as questões que havia levantado durante a aula. Nesse dia, enquanto eles escreviam o texto individual da primeira etapa, chamei aluno por aluno para lhes entregar o caderno mencionado a fim de que produzissem os textos opinativos, ao longo do bimestre.

Em outra aula, após escritura e reescritura com feedback, pedi aos alunos que se reunissem em grupos de acordo com as cores escolhidas para que pudessem construir um texto único que reforçasse o gosto deles por aquela cor. Mostrei-lhes que o objetivo era dar mais valor ao que diziam, juntando o máximo de argumentos possíveis. Pedi-lhes mais uma vez que tentassem fugir do, aparentemente, óbvio (verde, vegetação; azul, céu e mar; branco, cor da paz etc.).

Um problema que tive de enfrentar foi o fato de não haver grupo comum para todos. Poderia ter feito outras propostas de junção, mas, na hora de organizálos, considerei melhor formar grupos por cores com alguma relação, como, por exemplo, rosa e roxo ou roxo e azul ou ainda branco com preto. Não criei um critério para isso. Foi algo construído no momento em que me deparei com essa situação não prevista por mim. 


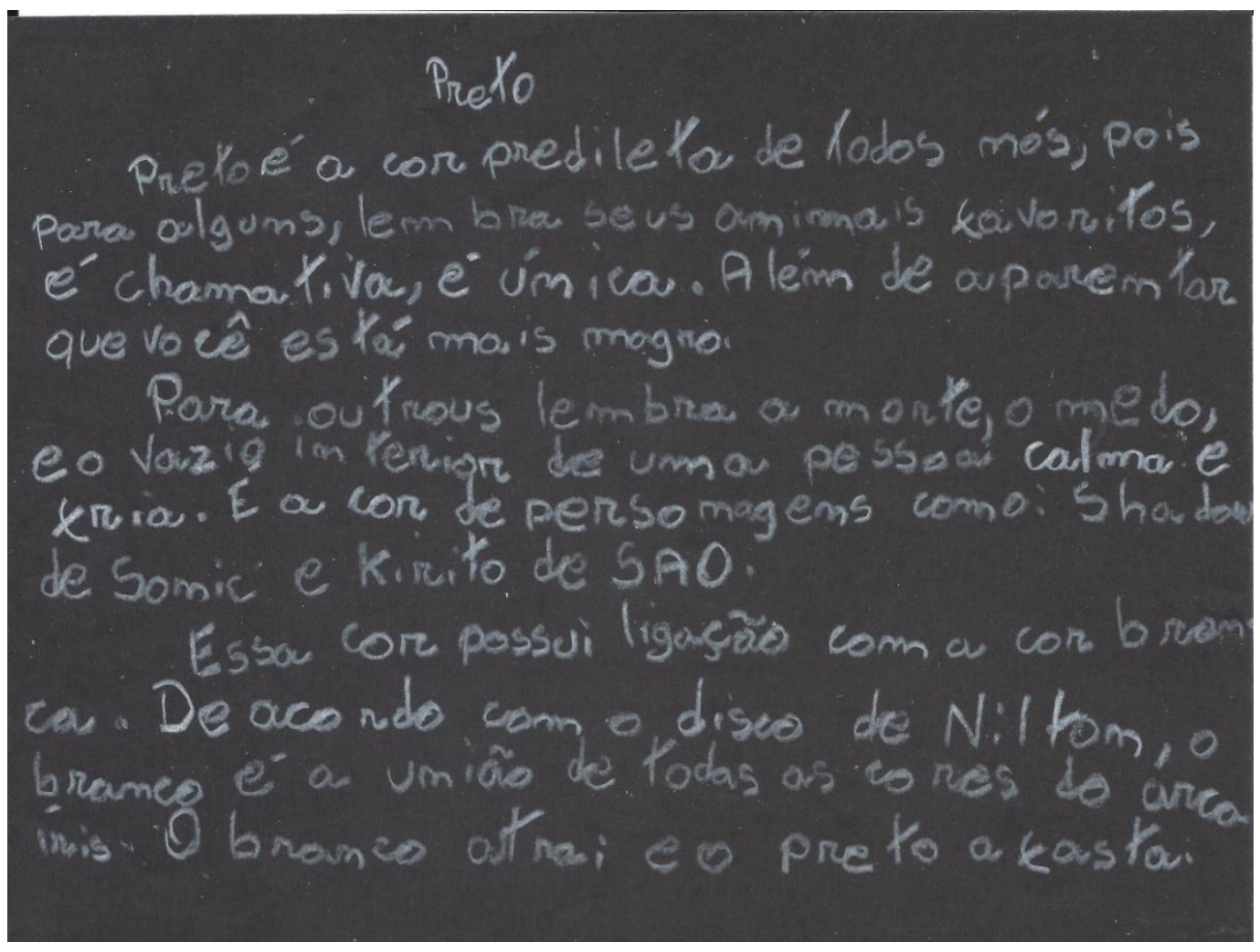

Figura 8: Junção de uma Guilda

Até aqui estava trabalhando conteúdos diversos, mais abertos pela sua flexibilidade textual, permitindo-me uma construção lúdica e bem rica com textos variados. Precisava, no entanto, adentrar na gramática, conteúdo que norteou a dinâmica escolar do ensino de Língua Portuguesa a vida inteira e que há alguns anos vem recebendo críticas e novas visões de ensino, mas que perpassa por um ponto importantíssimo: a capacidade de o professor inovar e aplicar as novas teorias numa prática, muitas vezes, corrida e difícil. A gramática tem, sim, de ser ensinada de forma contextualizada. Ela não pode ser o fim do ensino da língua materna, mas o meio para se fazer um bom uso dela. Nem sempre, no entanto, isso é facilmente aplicável em qualquer conteúdo, em qualquer situação, em qualquer ano de ensino.

Diante disso, tive muita dificuldade para montar uma atividade que não ficasse no processo de leitura de texto com a minha presença na frente da sala, para a aprendizagem inicial do Substantivo, principalmente porque há grande disparidade entre os alunos da instituição no que se refere ao conhecimento prévio desse e de tantos outros conteúdos. Os que ingressam por concurso público já vêm com boa parte da Gramática aprendida ou decorada. Em contrapartida, os que 
ingressam pelo processo assistencial, em número relevante,chegam ao $6^{\circ}$ ano sem nunca terem sido apresentados às ClassesGramaticais. Isso gera um problema real nos CM: trabalhar determinados conteúdos de forma que quem não conhece possa aprender e quem conhece não fique desestimulado ou atrapalhando o andamento da aula.

Pesquisando em livros e na web, encontrei uma dinâmica (a partir do jogo Adedanha, também conhecido como "Stop!") para se "brincar" apenas com substantivos. Era uma atividade proposta para crianças do Fundamental I, mas que podia ser muito bem aplicada à realidade do sexto ano do Fundamental II. Copiei a proposta, adaptei-a aos objetivos específicos do programa e a levei para a sala de aula. Essa foi a primeira e única atividade em que a dinâmica consistia em um jogo concreto, existente na sociedade. Na verdade, como critica Fortuna (2000, p. 6) utilizei o jogo como “"isca’ para fisgar o interesse dos alunos”. O que fiz nada mais é do que a "didatização do jogo".Mas era o que eu havia conseguido criar de mais aparentemente interessante para aquele conteúdo.

\begin{tabular}{|c|c|c|c|c|}
\hline $\begin{array}{l}\text { SERES LENDÁRIOS OU } \\
\text { PERSONAGENS DO } \\
\text { LIVRO }\end{array}$ & $\begin{array}{c}\text { CIDADES OU ESTADOS } \\
\text { DO BRASIL }\end{array}$ & $\begin{array}{c}\text { ANIMAIS DE NOSSA } \\
\text { FAUNA }\end{array}$ & $\begin{array}{l}\text { FRUTAS E COMIDAS } \\
\text { TÍPICAS BRASILEIRAS }\end{array}$ & $\begin{array}{l}\text { NOME DE UMA ACÃO } \\
\text { QUE GOSTO DE } \\
\text { PRATICAR }\end{array}$ \\
\hline & & & & \\
\hline & & & & \\
\hline & & & & \\
\hline & & & & \\
\hline & & & & \\
\hline & & & & \\
\hline $\begin{array}{l}\text { PROFISSÕES OU } \\
\text { ESPORTES }\end{array}$ & $\begin{array}{l}\text { NOME DE UM } \\
\text { SENTIMENTO OU } \\
\text { EMOÇAO QUE GOSTO } \\
\text { DE SENTIR }\end{array}$ & 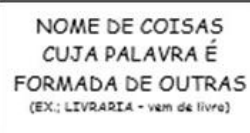 & $\begin{array}{l}\text { OBJETOS QUE } \\
\text { TENHO/VEJONA } \\
\text { ESCOLA/ }\end{array}$ & $\begin{array}{l}\text { NOMES DE COISAS } \\
\text { FORMADAS POR } 2 \text { OU } \\
\text { MAIS PALAVRAS } \\
\text { (EX; GUARDACGCHVAAS) }\end{array}$ \\
\hline & & & & \\
\hline & & & & \\
\hline & & & & \\
\hline & & & & \\
\hline & & & & \\
\hline & & & & \\
\hline
\end{tabular}

Figura 9: Base para o jogo Adedanha

Formei, então, seis grupos de alunos pelas fileiras de carteiras em que estavam sentados e marquei um tempo para cada rodada do jogo, Percebi logo a necessidade de aumentar esse tempo. Surgiram, porém, duas novas dificuldades: 
falta de vocabulário para um grupo bem representativo de alunos e dificuldade de lidar com as regras de um jogo, concreto e legítimo, em grupo. Após algumas rodadas em que percebi que o jogo não fluía bem, pedi-lhes que contassem as palavras escritas e avaliassem entre eles se tais vocábulos eram válidos em relação ao que se pedia na coluna. Cada grupo verificou o seu campeão e o tempo de aula acabou. Antes de sair de sala, porém, resolvi perguntar à turma quem nunca havia jogado adedanha. Contei sete alunos numa turma e, depois, oito alunos na outra. Entendi, em partes, o fato de eles estarem com tanta dificuldade em algo que eu previra facilidade.

Mesmo com o acontecido da última aula, resolvi dar continuidade ao jogo para que a atividade não fosse cortada ao meio. ${ }^{26}$ Procurei explicar-lhes as regras novamente. Muitos alunos, porém, ainda não conseguiam entender e colocar em prática a dinâmica. Infelizmente, não fechei a brincadeira como pretendia (o objetivo inicial seria levá-los ao reconhecimento de alguns tipos de substantivos. Dois alunos concursados numa turma e três na outra perceberam claramente, mas os demais ficaram sem entender). Tive de voltar à estrutura de aula tradicional explanativa. Usei algumas palavras que eles colocaram nas tabelas para lhes explicar o que é substantivo e mostrei, a partir do que pedia na adedanha, as classificações: próprio, comum, coletivo etc.

Fiquei bastante frustrada com essa atividade, mas talvez faça parte do processo de descoberta de novas formas de ensino. A minha expectativa por aulas dinâmicas, interessantes e lúdicas era ainda maior do que havia conquistado e desenvolvido até aquele momento. Hoje percebo que ainda não havia tido o verdadeito insight do que seria uma mudança de paradigma mais concreta.

\subsubsection{Missões lúdicas com enredo: o despertar da alegria}

Dispondo das guildas formadas ${ }^{27}$ e tendo como base uma leitura comum de guia, as novas atividades iniciaram com um enredo coeso e bem dinâmico.

\footnotetext{
${ }^{26}$ Essa é uma discussão pedagógica importante. Quantas vezes insistimos em repetir estratégias e atividades que não dão certo, que não surtem, de fato, a aprendizagem pelos alunos, só porque gostamos dela, é a nossa zona de conforto ou ainda porque já temos as aulas todas prontas?

${ }^{27}$ Como apresentado na página 66.
} 
As seis atividades tinham uma costura narrativa entre elas tão intensa, isto é, havia um enredo que as mantinha em um elo sequencial que tornava cada missão como parte de um todo maior e claro. Quando esse enredo se esgotou, continuei promovendo atividades com intensidade lúdica e produção prática realizada pelos alunos (serão apresentas logo a frente como "Missões Lúdicas"), mas elas eram independentes, sem a costura da história, embora, logicamente, fizessem parte de um todo no conjunto dos conteúdos a serem trabalhados no sexto ano.

A seguir, um quadro com a visão geral das missões lúdicas com enredo que mostra de forma resumida a essência de cada uma das atividades e as metas a serem atingidas. 


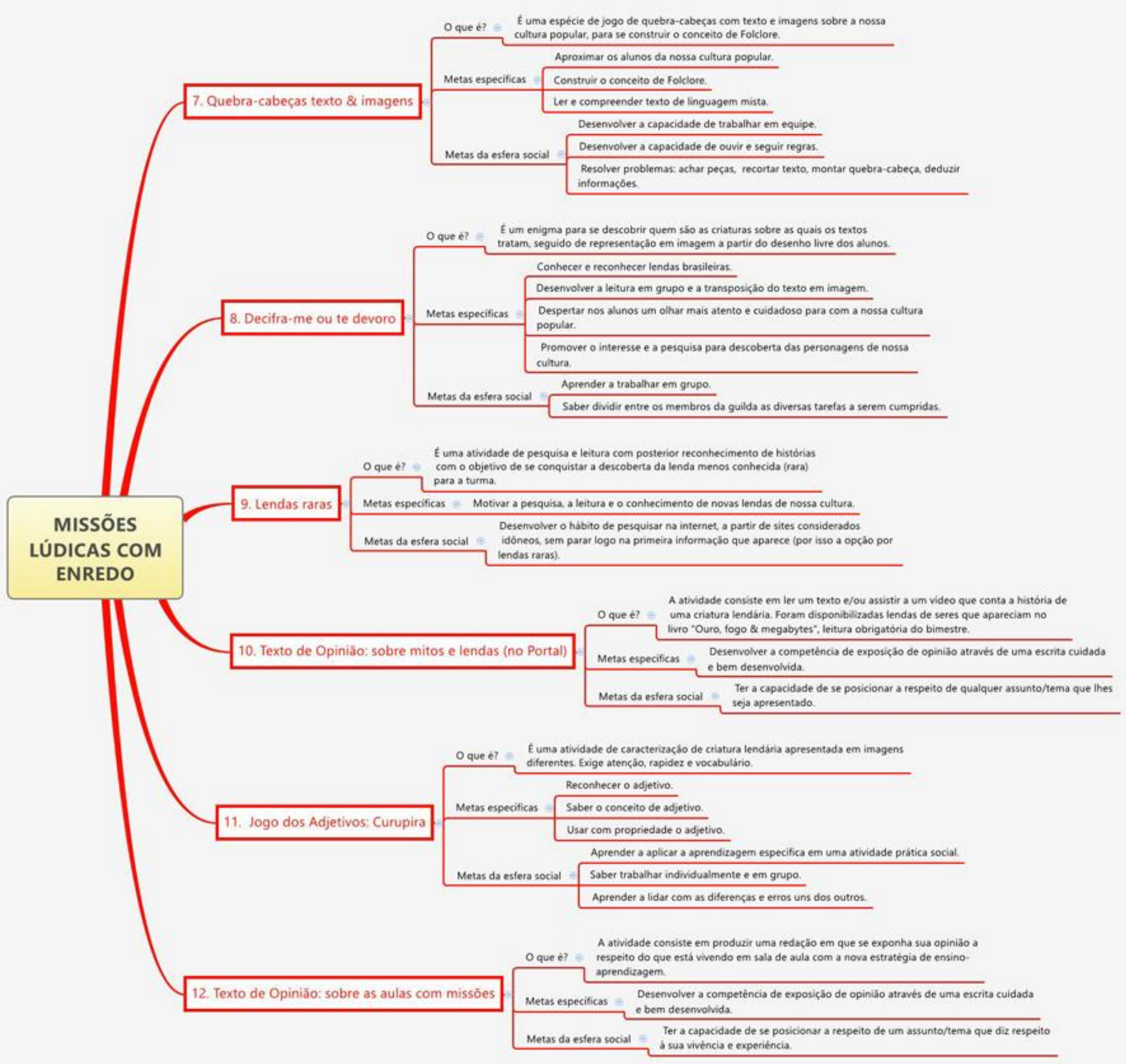

Quadro 6: Panorama Geral das missões lúdicas com enredo, com quadro explicativo. 
As três primeiras atividades apresentadas no quadro exploravam a organização, a colaboração e a cooperação dos membros das guildas para que pudessem cumprir todas as missões de acordo com as regras. Os alunos tinham de montar um texto como se fosse um quebra-cabeças, encontrando peças desse texto espalhadas e misturadas pela sala de aula e precisavam entender a mensagem do texto, para lê-lo por inteiro, "traduzindo" também as imagens; era necessário decifrar lendas para descobrir os seres a que se referiam; e tinham de pesquisar lendas raras para dificultar ao máximo a descoberta dos colegas de outras guildas.

Observando as missões assim, resumidamente, é possível destacar quanta leitura foi feita pelos alunos em tão pouco tempo e com tanto interesse, boa vontade e dedicação. A terceira missão, por exemplo, tinha de ser realizada inicialmente em casa para se desenvolver em aula. Ela possibilitou a prática de um tipo de pesquisa na internet que pouco vejo desenvolvido ainda hoje na escola. $\mathrm{O}$ processo de pesquisa informacional e de descoberta pontual (conteúdo específico, objetivo) a que estávamos acostumados com as enciclopédias e bibliotecas já não tem mais validade desde o advento da Web. Descobrir, por exemplo, quem é considerado o maior folclorista do Brasil é muito pontual e pouco produtivo, basta colocar no buscador Google a expressão "maior folclorista brasileiro". 


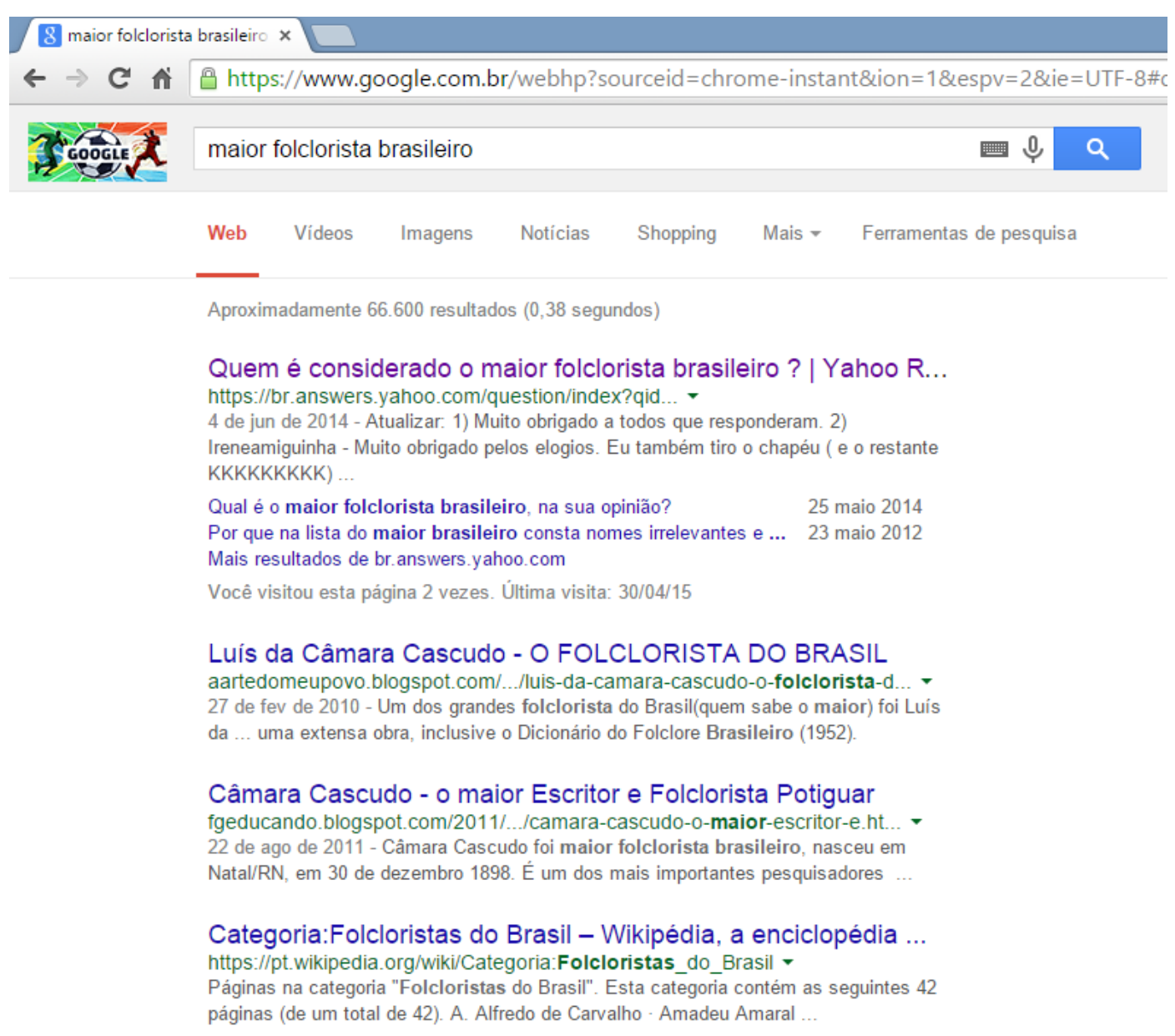

Figura 10: Pesquisa feita no buscador "Google" sobre o maior folclorista brasileiro. ${ }^{28}$

Pesquisar, no entanto, lendas raras brasileiras a ponto de escolher uma para representar o seu grupo numa disputa com outros grupos é uma ação mais complexa, pois não há um resultado objetivo para isso.

${ }^{28}<$ https://www.google.com.br/webhp?sourceid=chrome-instant\&ion=1\&espv=2\&ie=UTF$8 \# q=$ maior $\% 20$ folclorista\%20brasileiro $>$ 


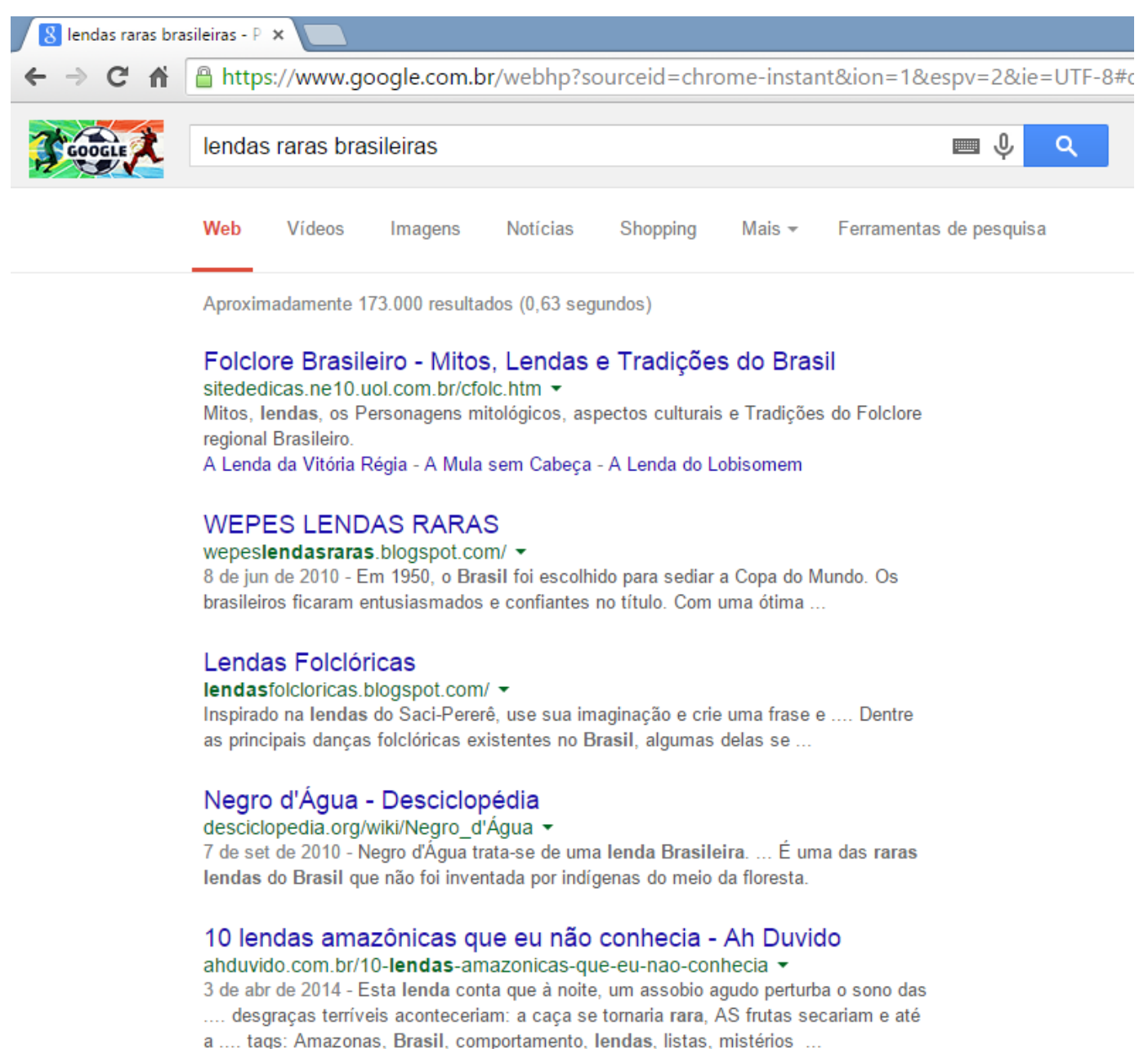

Figura 11: Pesquisa feita no buscador "Google" sobre a lenda brasileira mais rara. ${ }^{29}$

O que tiro dessa experiência é que localizar e selecionar informações válidas na internet talvez seja umas das funções mais importantes da aprendizagem da leitura de mundo hoje. A escola não pode se furtar a promover essa experiência prática inúmeras vezes ao longo dos anos escolares, já que essa mídia éa mais utilizada hoje na busca por informações, conteúdos, conceitos etc. Mas também é preciso que o leitor aprenda a avaliar a informação de forma crítica e com competência, o que não se faz de um dia para o outro nem com questões pontuais e objetivas como a busca do maior folclorista brasileiro. Uma pesquisa como a de lendas raras, por exemplo, promoveu uma valiosa e complexa experiência que lhes permitiu aprofundar as buscas pelo interesse e dificuldade em um limite aceitável.

\footnotetext{
${ }^{29}<$ https://www.google.com.br/webhp? sourceid=chrome-instant\&ion=1\&espv=2\&ie=UTF$8 \# \mathrm{q}=$ lendas+raras+brasileiras $>$
} 
O resultado dessa missão pôde ser quantificável: numa turma com seis grupos de cinco alunos cada (alguns tinham quatro), cada aluno teve a oportunidade de ler, no mínimo, quatro lendas no seu grupo e, depois, ouvir outras cinco lendas dos grupos adversários. Isso significa que em dois tempos de aula foram conhecidas, pelo menos, nove lendas da nossa cultura, numa dinâmica que se mostrou instigante e motivadora, na qual, mesmo os alunos que não gostavam de ler e por isso não mergulharam a fundo na parte da atividade feita em casa, acabaram se envolvendo pelo interesse despertado pela atividade. Houve relatos de alunos que leram, previamente, mais de quinze histórias para escolher uma que considerasse rara para a disputa.

Simultaneamente a essas missões, os alunos tiveram acesso pelo Portal Educandus a outras lendas, em texto e em vídeo do Youtube, com o objetivo não só de conhecer mais histórias, como também treinarem a expressão da opinião. Apesar de não ter sido totalmente aproveitada porque o acesso ao portal ainda era problemático para alguns alunos, pude observar uma pequena diferença que marcou como positiva a metodologia que vinha utilizando com exigência de escrita semanal e feedback direto e rápido. Era bem distinto o nível dos comentários escritos por alunos das turmas pesquisadas (AutorB34, AutorA44, AutorA23 e até aAutorA9, apesar de sua dificuldade) para os escritos pelos alunos de outras turmas ${ }^{30}$. Estava sempre tentando desenvolver a proposta de eles se expressarem muito além do apenas dizer "legal" e "bom" para aprenderem a expor suas impressões e opinião. Esse trabalho era diário e com feedback constante.

A quarta missão recebeu o nome de "jogo dos adjetivos". Criei - a partir da apresentação, em momentos separados, de três imagens bem distintas do Curupira - uma atividade inicialmente individual, que seguia de uma reconstrução nas guildas, para, em seguida, realizarem outra atividade semelhante, mas que dependia da atenção, da cooperação e organização do grupo. Na primeira etapa da atividade, os alunos tinham de caracterizar, utilizando adjetivos, os Curupiras cujas imagens lhes eram mostradas em data-show. Havia uma disputa individual por quantidade de adjetivos utilizados (vocabulário) em relação ao tempo estipulado. Na segunda etapa, a disputa dizia respeito à quantidade de adjetivos

\footnotetext{
${ }^{30}$ Exemplos dessa distinção serão apresentados no capítulo 6.
} 
válidos e não repetidos somados por todos os membros em cada guilda. A terceira etapa dependia de uma construção um pouco mais elaborada, pois exigia vocabulário variado (não podia repetir um mesmo adjetivo), coerência nas caracterizações (não podia haver antônimos ou ideias incompatíveis) e rapidez (a guilda precisava ser organizada e atenta).

Como procurava fazer semanalmente, após essa atividade, os alunos produziram, no caderno de opinião, um texto sobre o que estava acontecendo nas aulas, o que eles estavam gostando ou não etc. Essa foi a quinta missão. Os relatos foram bem importantes para a avaliação do andamento da pesquisa.

\subsubsection{Missões lúdicas: a descoberta do que não se sabia}

Terminada a narrativa do que chamei de "Missões Lúdicas com Enredo", dei continuidade às "Missões Lúdicas", mas, como já foi mencionado, sem uma história única que as costurasse. Se, num primeiro momento, fiquei preocupada com essa perda, depois, fui percebendo que um semestre é muito tempo para se manter uma grande atividade lúdica com uma só "costura”. Então, entendi que as atividades seguintes tinham características e qualidades próprias em si mesmas e davam conta dos conteúdos e objetivos a serem alcançados.

No terceiro bimestre, realizamos as seguintes atividades, resumidas no quadro abaixo, além de termos tido a oportunidade de conhecer e conversar (todo o sexto ano) com o autor dos livros Ouro, fogo \& megabytes e Prata, terra \& lua cheia, Felipe Castilho. Segue o quadro explanativo das missões lúdicas: 


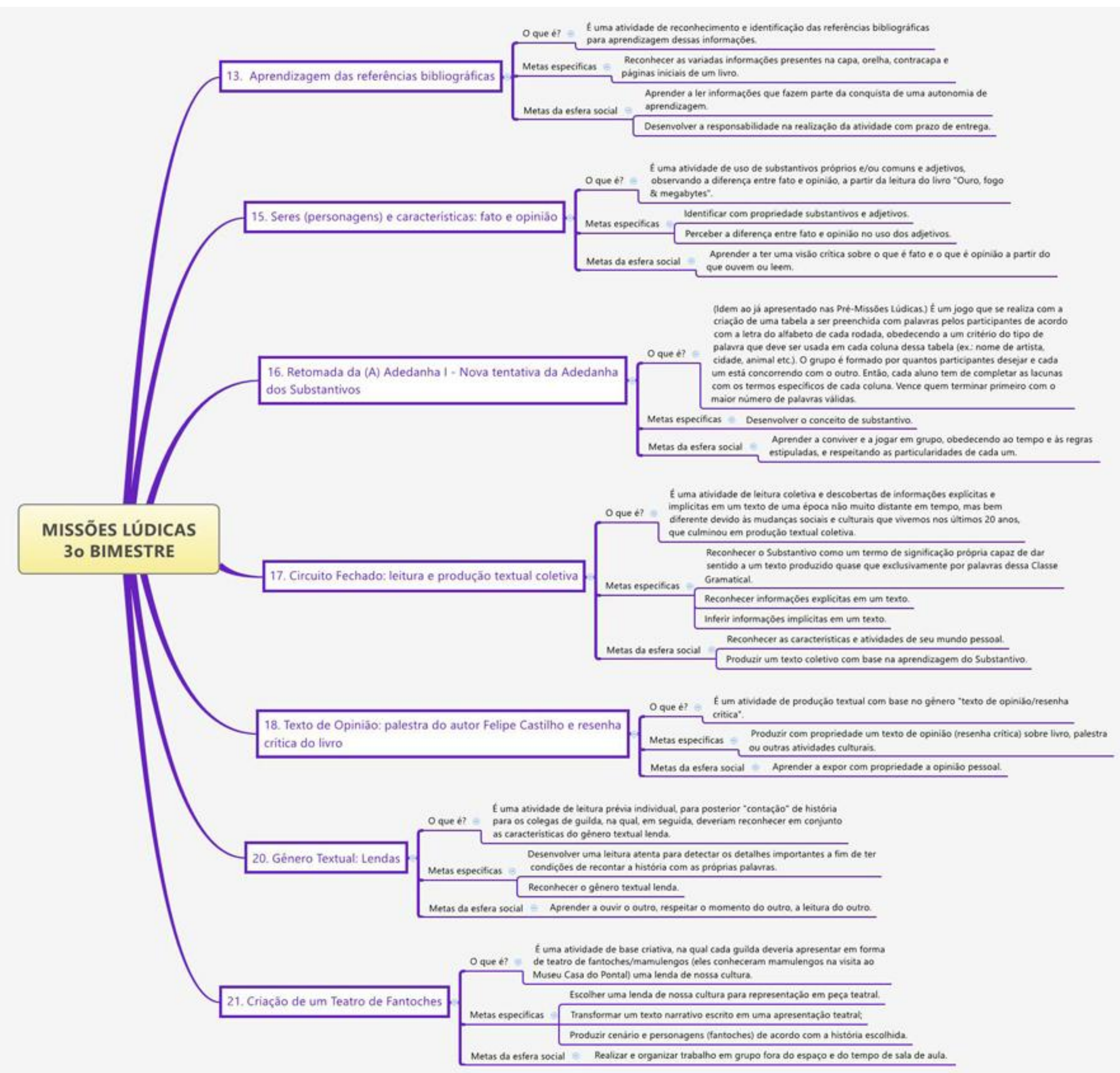

Quadro 7: Panorama geral das missões lúdicas do terceiro bimestre, com quadro explicativo. 
Entre a missão dos adjetivos (Item 11, quadro 4, "Missões Lúdicas com Enredo") e a missão dos dados bibliográficos (Item 13, quadro 5, "Missões Lúdicas", $3^{\circ}$ Bimestre), houve a palestra do autor Felipe Castilho, que proporcionou aos alunos do sexto ano inteiro uma visão de autor-leitor para se tornar um escritor. Depois disso, tive de retornar ao modelo de aula bem tradicional, expositiva, sobre construção de texto de opinião (produção textual) porque estava percebendo que alguns alunos não vinham produzindo corretamente (nem com empenho) seus textos opinativos. Como faz parte do programa produzir um texto de opinião para ser corrigido e avaliado, com nota, resolvi, então, aproveitar a experiência com a palestra para produzir com eles, durante a aula, uma redação completa, desde a criação de perguntas norteadoras para se construir um roteiro de escrita até a produção do texto. Fiz isso a fim de que eles tivessem todas as informações necessárias para, depois, produzirem uma resenha crítica sobre o livro lido. Após essa aula expositiva, passei para casa a tarefa de eles escreverem também um texto individual sobre o mesmo tema trabalhado em sala, no qual apresentassem, de forma clara, a visão deles sobre o que vivenciaram naquele dia. Era uma forma de aprender na prática pessoal o que eu estava mostrando a eles no coletivo. Fiz isso a fim de capacitá-los para a produção textual do bimestre que seria comum a todas as turmas: uma resenha crítica sobre o livro paradidático lido (Item 18, quadro 5, "Missões Lúdicas”, $3^{\circ}$ Bimestre).

Após a aula expositiva de texto de opinião, iniciamos uma nova missão (Item 15, quadro 5, "Missões Lúdicas" $3^{\circ}$ Bimestre), também individual, em que eles precisavam fazer uso dos adjetivos, observando a diferença entre fato e opinião. A atividade exigia que o aluno preenchesse um quadro com três personagens presentes no livro Ouro, fogo \& megabytes à sua escolha (humanos ou criaturas lendárias). Nesse sentido, estávamos trabalhando com substantivos, que poderiam ser próprios (o nome da personagem) ou comuns (se fizesse menção a uma criatura lendária geral, como o mão-pelada, por exemplo) e adjetivos, pois, depois dos substantivos apontados, o aluno deveria apresentar para cada uma dessas personagens seis características (adjetivos simples), sendo três que representassem fatos e três que fossem a opinião do narrador sobre a personagem.

Logo após essa missão, insisti no retorno à dinâmica da Adedanha dos Substantivos por uma curiosidade (ou inconformismo) pessoal. Nessa segunda 
experiência, os alunos já estavam em suas guildas (na primeira tentativa, havia formado os grupos pelas fileiras de carteiras). Expliquei novamente a atividade e lhes dei meia hora nas guildas para jogarem. Mesmo com esse tempo, eles não conseguiram fechar todos os espaços (número de jogadas) e nós não conseguimos aproveitar muito a atividade no proceso. Apenas retomei, mais uma vez, a estrutura tradicional de aula para me assegurar de que os conceitos de substantivo estavam sólidos para os alunos e de que eu não estaria falhando na "transmissão" de conteúdos obrigatórios ao ano. Talvez uma regressão minha ao modelo clássico de professora!

$\mathrm{Na}$ aula seguinte, iniciamos um trabalho ainda com base nos substantivos a partir do texto "Circuito fechado", de Ricardo Ramos, que resultou numa produção textual coletiva (nas guildas): construir o "Circuito Fechado" de um aluno do sexto ano do CMRJ. Esse trabalho começou com a leitura dinâmica e instigante do conto, com a decifração de diversas situações que hoje causam estranhamento ao jovem do século XXI, e culminou com uma produção textual coletiva em que os alunos, em suas guildas, tinham de apresentar um dia da rotina de um aluno do CMRJ no ano de 2015, em um circuito também fechado, isto é, da hora que acorda à hora de dormir. 


\section{Circuito Fechado}

Cama, elespertador, pia, água, uscova, dente, dedo, celular, Rão, unanteiga, nescau, banheiro, uscova, dente, dedo, ‘ Cluear, voupa, elevador, tablet, portaria, celular, transporte, mão, Cablo, converra, celular, uscola, mochila, rala, escada, formatura matimal, uscada, usala, Carteira, conversa, celuear, riso, lápis, material, matéria, liuro, estudo, escado, pátio, celular, lanche, Caderno, sala, Carteira, celular, professor, giz, caneta, quadro, atioidade, estudo, anotação, RD, japona, bankeiro, água, raro usanitáxio, mõo, água, corredor, sala, pernisSá, aula, rinal, escada, celular, cantina, doce, portão, rua, transpate, conversa, casa, portaria, eleva. dor, corredor, porta, raupa, almos, televisä, bankirro, pia, água, escava de dente, pasta de dente, mesa, cadeira, lápis, dever de casa, luro, mochila, Gelular, descanso, telerisiao, lanche, bankeiro, taso sanitário, pia, água, măo, krincadeira, fanta, celular, múrica, fone, escovo de dente, computadior, telewisäo, cama. cobertor, Glubar, travesseiro, sono.

Figura 12:Texto "Circuto fechado" de uma guilda da Turma A.

chinelos, varo, dercargo. Encoro, águo, parto des dente, áquo. Celular, mensogem, libuso, lakfa, rópat to boino, mochilo, automórel, pouto, linto, celubar, gogo, enquerdo. dirita, funte, encolo. continéncía, foematuro, nentido, dencans ar, aprenentafaio de turmo, encado, elular, linson, lópius, bocracho, eansto, coderno. Proflennoro, aulo, matimátics,

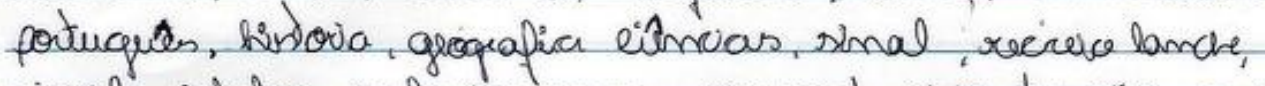
simal, elubar, aulo comserno, provo, durvido, tençäo, rempontas; mervonimo, val alino de easo, eoureciáo. Hochilo, mateval, smal

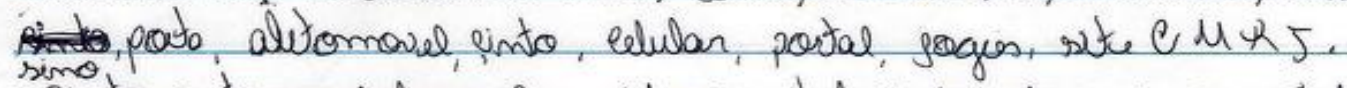
sinto porto, mochlo, rofo, ulmose, telenilsia, deviende cane, tele-

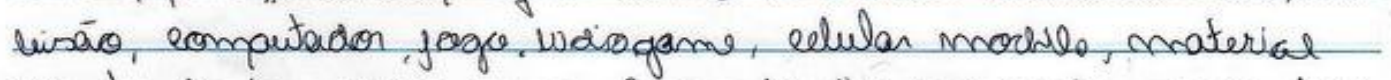
pronto. fantor, suco, arroz, ferjac banino, shamoso condico. nado, rabonete, toalho thinelo, banheiro, dexcargo, tornerno,

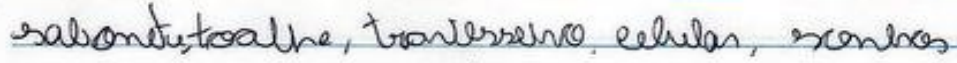

Figura 13:Texto "Circuto fechado" de uma guilda da Turma B. 
Esse trabalho possibilitou que eles e eu visualizássemos seus hábitos e costumes para conseguir apresentar uma rotina comum a alguém de sua idade, com um tempo e um espaço demarcados, e me confirmou um mundo mergulhado nos jogos e redes sociais a partir de seus celulares.

As duas últimas atividades realizadas dentro do tempo cronológico do terceiro bimestre (o teatro de fantoches foi proposto nesse período, mas só foi apresentado no início do quarto bimestre) retomaram o gênero textual lendas. Como até o momento só havíamos lido lendas brasileiras (mesmo de base indígena, africana ou afro-brasileira), levei para a sala de aula um número suficiente de histórias (onze lendas) para que cada duas guildas recebesse uma lenda diferente por membro (Item 20, quadro 5, "Missões Lúdicas", $3^{\circ}$ Bimestre). Foi uma atividade de leitura e desenvolvimento da capacidade de recontar a história lida para os colegas. Em seguida, eles, em conjunto, tiveram de refletir e responder a duas perguntas: "Para que servem as lendas?" e "O que esses textos têm em comum para serem considerados pertencentes ao gênero textual "lendas"?"

A última missão proposta no terceiro bimestre, criação de uma peça de teatro de fantoches, tentou englobar vários conhecimentos adquiridos ao longo desse período. Consistia em apresentar uma lenda de nossa cultura em forma de teatro de fantoches/mamulengos como eles conheceram na visita ao Museu Casa do Pontal. Essa atividade visava a realização de um trabalho em grupo fora do espaço e do tempo de sala de aula (normalmente evitamos esse tipo de exigência porque as crianças moram muito longe umas das outras), mas que, se bem coordenado, poderia ser produzido por cada membro em separado, desde que houvesse uma boa troca e comunicação. Como já mencionei, essa proposta foi lançada no terceiro bimestre, mas só foi apresentada após as AE, na primeira semana de aula do último bimestre. Isso foi feito assim para que eles pudessem se quisessem - usufruir do tempo sem aula na escola durante a semana de provas até a saída do transporte (cerca de uma hora após o término geral da avaliação) para produzir o trabalho ${ }^{31}$.

\footnotetext{
${ }^{31}$ Retornarei a essa proposta logo no início do próximo capítulo.
} 


\subsubsection{As relações na aprendizagem: uma percepção do todo (parte 1)}

Depois de realizar todo esse trabalho ao longo do terceiro bimestre letivo, pude verificar que as inter-relações que se construíam entre os conteúdos (Objetos de Conhecimento) de cada prática nas missões propostas aumentavam conforme eu desenvolvia mais o trabalho com produções textuais variadas.

O primeiro quadro que segue destaca os conteúdos desenvolvidos no período a que nomeei de Pré-Missões Lúdicas. Cada uma das práticas (Escuta e Leitura; Produção de Textos; Análise Linguística) é apresentada com uma cor diferente e essas cores são usadas em símbolos (triângulo roxo, estrela laranja e seta verde) para clarificar, além das linhas já usadas, com que práticas determinado conteúdo foi desenvolvido. A imagem explicita bem a dificuldade inicial que tive para trabalhar o Substantivo. Apesar de minha experiência no desenvolvimento desse conteúdo por meio da leitura de textos, ao buscar uma prática aparentemente mais interessante, recaí no isolamento de um conteúdo gramatical.

O segundo quadro, por sua vez, já vai demonstrar um inter-relacionamento bem mais intrincado. Os conteúdos assinalados foram desenvolvidos nas atividades realizadas nas Missões Lúdicas. Os símbolos se mantêm como descrito acima, para auxiliar, além das linhas, na percepção das relações dos conteúdos através das variadas práticas. 


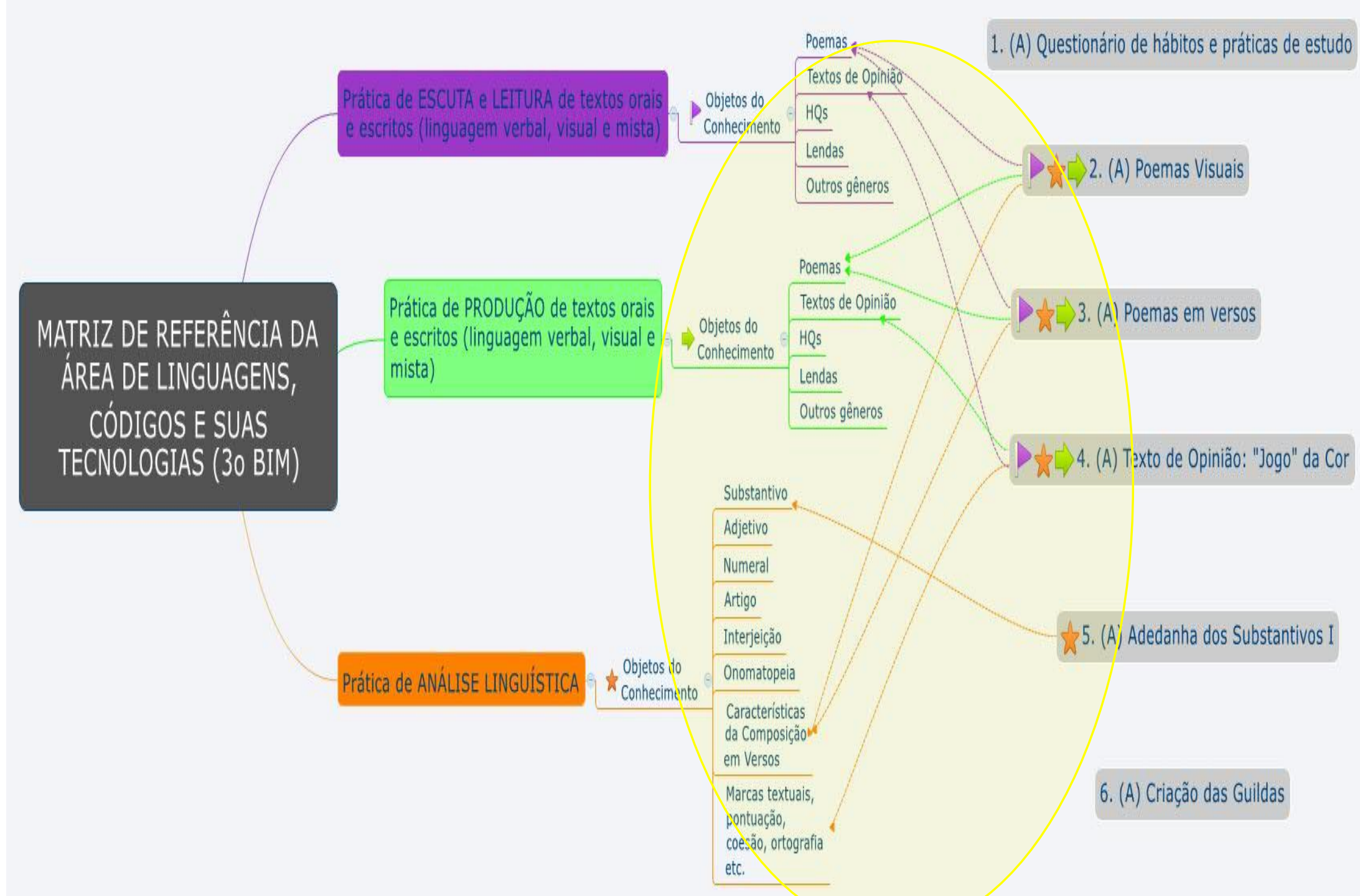

Quadro 8: Inter-relações dos conteúdos de LP por meio de variadas práticas nas Pré-Missões Lúdicas. 


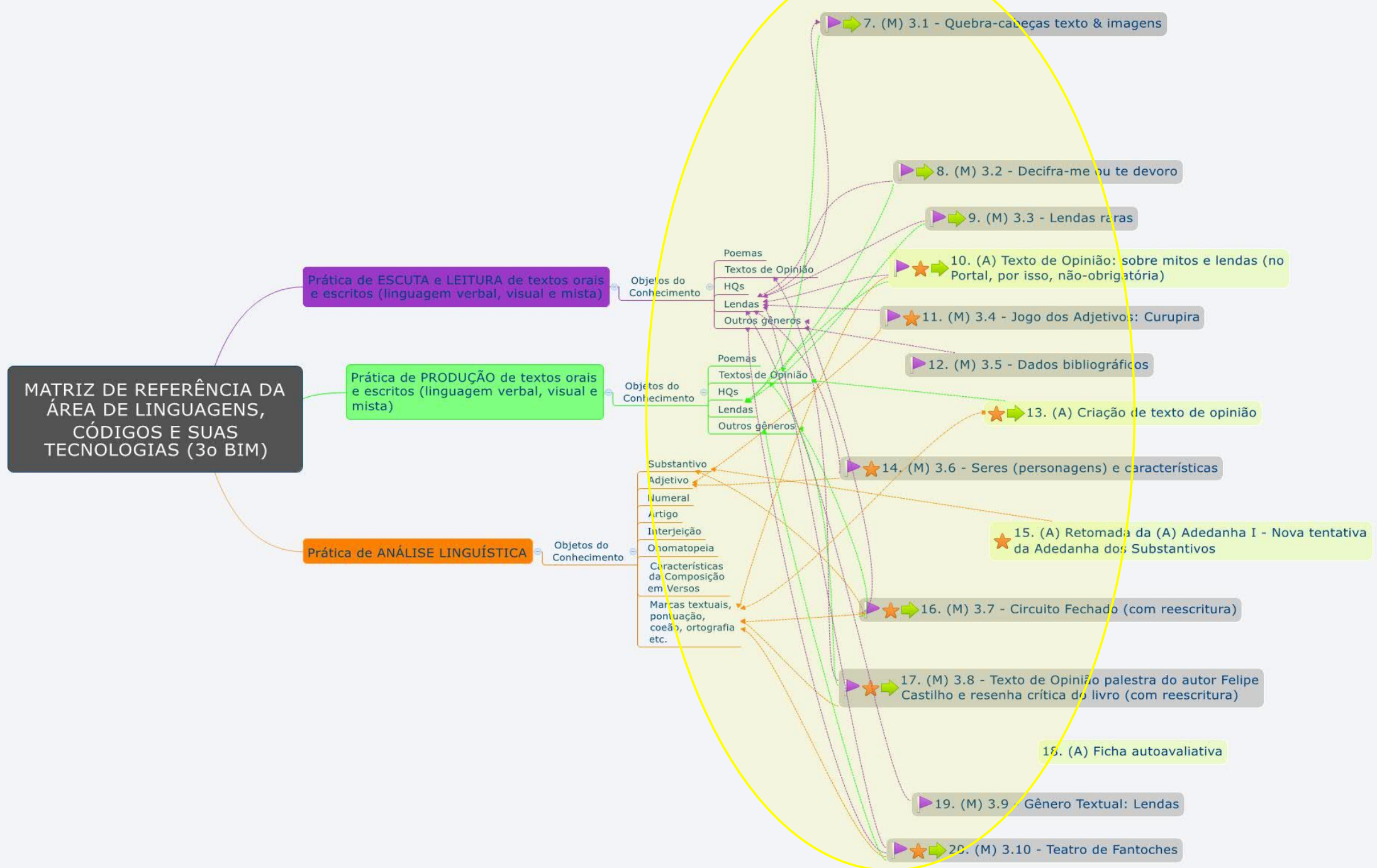

21. (A) Encerramento do Bimestre e Premiação

Quadro 9: Inter-relações dos conteúdos de LP por meio de variadas práticas nas Missões Lúdicas (com e sem enredo). 
Tendo em vista a interrupção das aulas para a realização das $\mathrm{AE}$, encerramos as atividades lúdicas do terceiro bimestre em setembro para retomar uma semana depois com o início do quarto bimestre. O intervalo sem aulas foi curto, mas muito intenso de produção de trabalho e estudo para os alunos, e isso será visto desde o início do próximo capítulo com as criações do teatro de fantoches e do primeiro texto de opinião sobre a semana de provas. 


\section{A implantação da experiência:segundo período da pesquisa ( $4^{\circ}$ bimestre do ano letivo)}

Este capítulo apresenta a descrição objetiva das atividades planejadas e desenvolvidas ao longo do quarto bimestre, incluindo as Missões Culturais Extracurriculares, que se desenvolveram, de forma facultativa, além dos muros da escola.

\subsection{Missões lúdicas: grandes descobertas}

O quarto bimestre teve início na terça-feira, dia 16 de setembro. Começamos fechando as atividades do terceiro (o teatro de fantoches e a premiação das guildas).

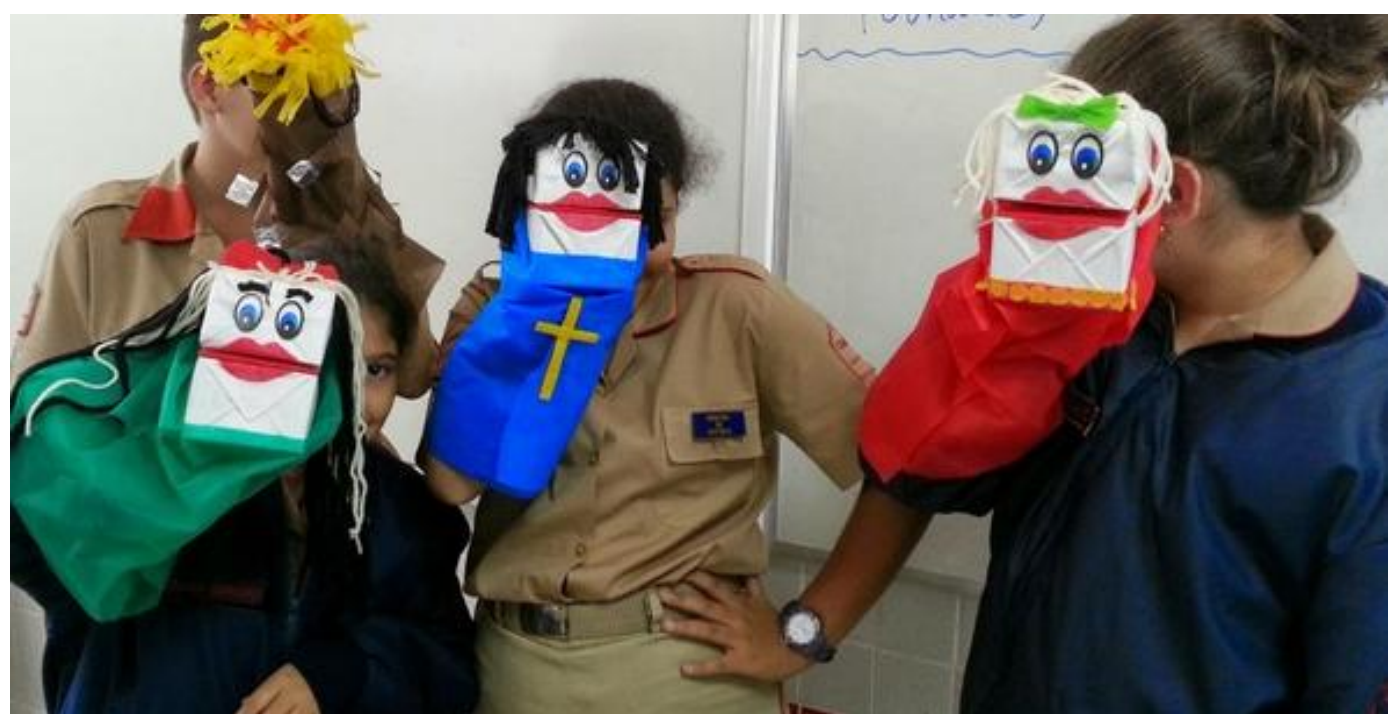

Foto 4: Apresentação do Teatro de Fantoches, alunos da turma B. 


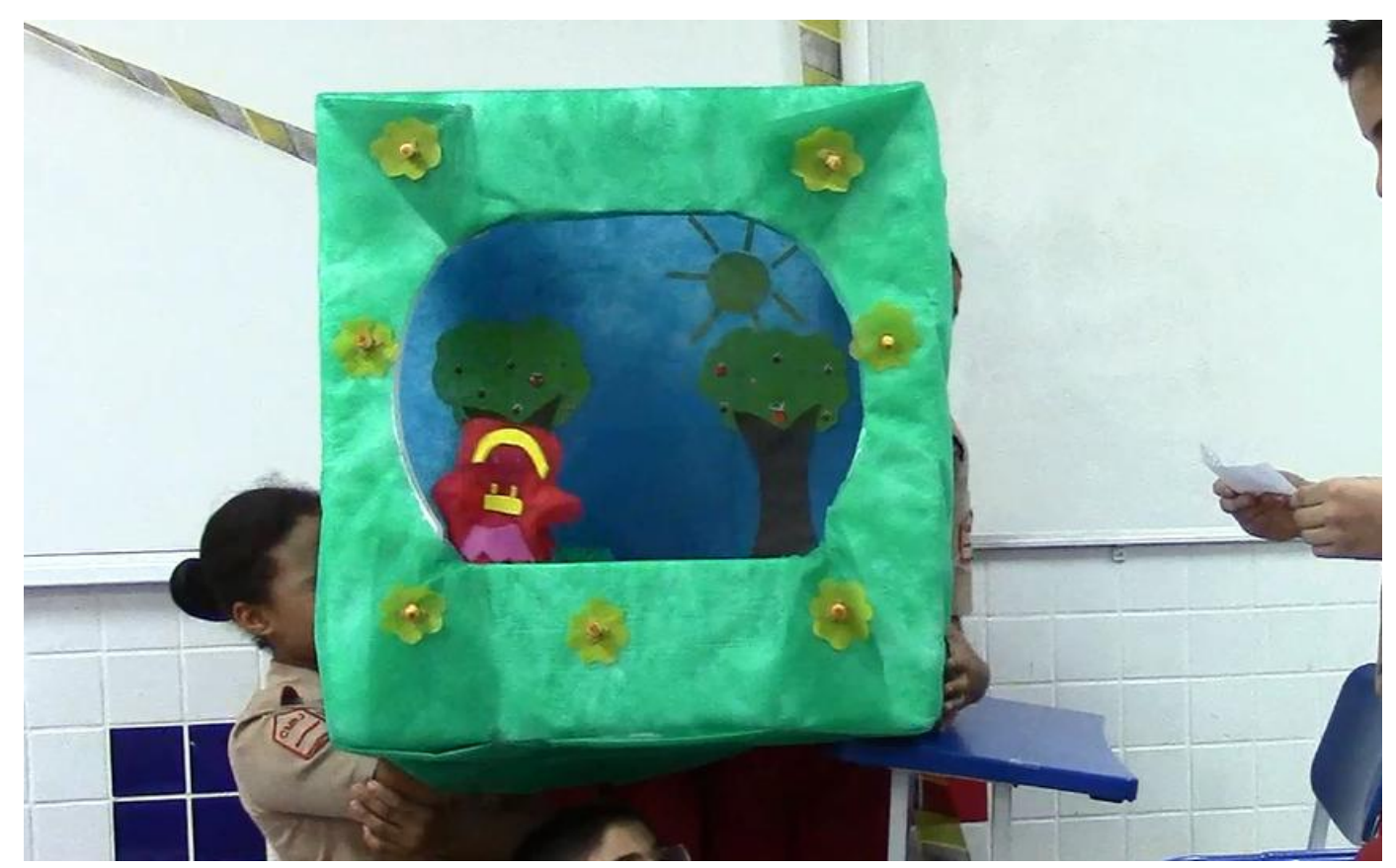

Foto 5: Apresentação do Teatro de Fantoches, alunos da turma A.

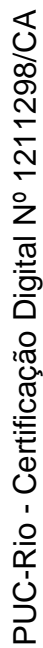

O conteúdo desse período, de acordo com o programa, foi desenvolvido a partir das seguintes missões apontadas nos dois quadros explanativos abaixo: 


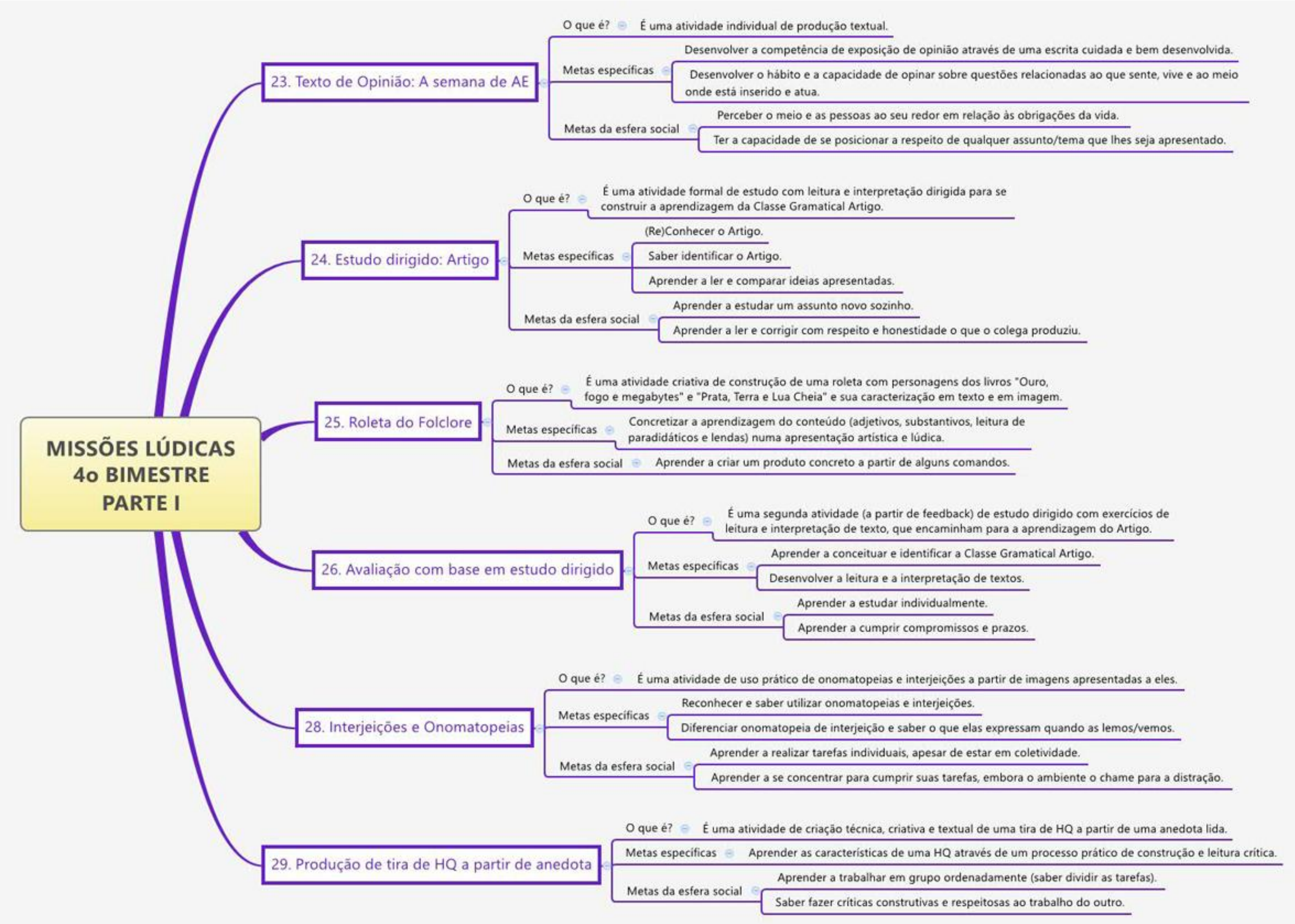

Quadro 10: Panorama geral das missões lúdicas do quarto bimestre - Parte I, com quadro explicativo. 
O que é? \& Euma atividade de produção de texto opinativo.

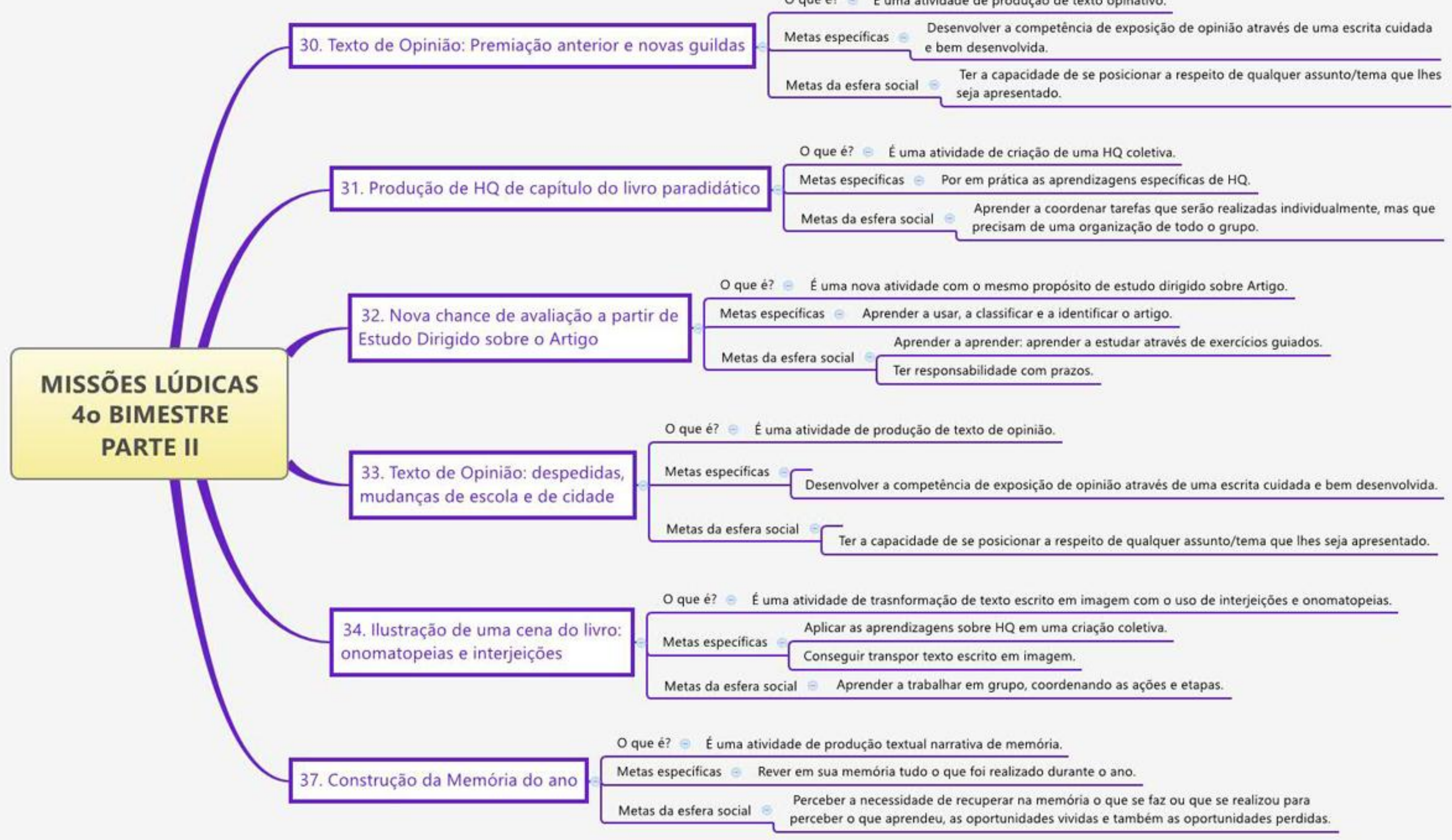

Quadro 11: Panorama geral das missões lúdicas do quarto bimestre - Parte II, com quadro explicativo. 
Apesar de afirmar que não consegui retornar a uma dinâmica com enredo em momento algum dessa etapa, o período foi intenso, de muito trabalho e produção para os alunos e para mim. Percebi depois que ocorreram produções mais abrangentes e criativas que no bimestre anterior e também bastante lúdicas em suas dinâmicas e objetivos. Por isso, o feedback teve de ser constante e rápido. Eles escreveram vários textos: não só redação como texto de opinião ${ }^{32}$, mas também memória do ano em resumo ${ }^{33}$, texto informativo para a roleta ${ }^{34}$, tiras e $\mathrm{HQ}^{35}$, entre outros.

A primeira atividade específica do bimestre foi a produção escrita da experiência deles sobre as atividades realizadas. Pedi-lhes que expusessem seus sentimentos e emoções sobre o período destinado exclusivamente às $\mathrm{AE}$ (as conhecidas e muito temidas, pelos relatos apresentados, provas bimestrais). Esses textos são bem interessantes pela honestidade deles com relação a esse momento obrigatório de suas vidas e da vida de qualquer estudante. ${ }^{36}$

Tomo a liberdade aqui de apresentar um grupo de missões propostas sem acompanhar a ordem cronológica de sua realização. Faço isso porque uma foi fator gerador direto das outras. As atividades a que me refiro são: o estudo dirigido sobre o Artigo (item 24, quadro 6); a avaliação com base no estudo dirigido (item 26, quadro 6); a nova chance de avaliação a partir do estudo dirigido sobre o Artigo (item 32, quadro 7).

Preciso afirmar que, tendo dificuldade de visualizar de forma clara e dinâmica uma proposta criativa e envolvente para a aprendizagem do Artigo (Classe Gramatical), enxerguei no estudo dirigido uma alternativa de resolver essa minha limitação. Baseei-me na ideia de que qualquer atividade pode ser interessante desde que bem proposta e adequada à idade, ao tempo, à situação. No entanto, me deparei, logo de início, com um baixo nível de envolvimento dos alunos e problemas gerados com prazos de entrega não cumpridos. Autoavaliando-me no que e no como estava produzindo a proposta e avaliando-os, expondo a eles o que havia enxergado e o que pensava sobre o assunto, criei

\footnotetext{
${ }^{32}$ Itens 23, 30 e 33, quadros 6 e 7, "Missões Lúdicas", partes I e II, $4^{\circ}$ Bimestre.

${ }^{33}$ Item 37, quadro 7, "Missões Lúdicas", parte II, $4^{\circ}$ Bimestre.

${ }^{34}$ Item 25, quadro 6, "Missões Lúdicas", parte I, $4^{\circ}$ Bimestre.

${ }^{35}$ Itens 28, 29, 31 e 34, quadros 6 e 7, "Missões Lúdicas", partes I e II, $4^{\circ}$ Bimestre.

${ }^{36}$ Devido às ricas falas dos alunos sobre essa experiência tão tradicional nas escolas desde a sua origem até nossos dias, essas produções serão destacadas quando eu apresentar a discussão dos dados.
} 
outras alternativas em que dava aos alunos chance de aprender, recuperando-se das falhas de aprendizagem e dos erros no processo por mais de uma vez. Fiz isso por meio das duas oportunidades formuladas a partir do primeiro "Estudo Dirigido" sobre o Artigo. Essas missões foram realizadas parte em sala e parte em casa, com momentos distintos. Primeiro, eles deveriam, individualmente, fazer a folha de Estudo Dirigido entregue a cada um. Em seguida, reuni-os nas novas guildas e lhes entreguei uma espécie de respostas sugeridas comentadas para fazerem uma correção, uns dos outros daquilo que tinham feito. Na segunda parte (em grupos), eu queria que eles lessem as respostas dos colegas e avaliassem se estavam corretas ou não a partir das sugestões que eu lhes havia passado para a realização dessa correção. Meu objetivo era que eles percebessem como é importante ler e entender o que está escrito e, consequentemente, ver como é importante se fazer entender ao outro que lerá o que escreveu.

Feita essa dinâmica, elaborei,mais a frente, outro "Estudo Dirigido" para lhes dar a chance de ratificar a aprendizagem realizada, valendo nota (tinha que compor a média de avaliações prevista pela instituição), porém com total liberdade para consulta, visto ser um estudo feito em casa, e não um teste na sala de aula. Infelizmente, porém, a missão não teve o sucesso esperadopor mim. Os alunos entregaram a tarefa feita com muita displicência, segundo a minha leitura como"professora tradicional”. A atividade se baseava inicialmente numa proposta do livro didático deles com uma recriação minha. Havia instruções também criadas por mim para que eles pudessem pesquisar e desenvolver o que lhes era pedido, mas grande parte dos alunos nada pesquisou nem fez a parte de interpretação de textos corretamente. O resultado dessa avaliação foi muito baixo: 4,2 de média geral. Preparei, a partir disso, uma aula geral chamando a atenção para os erros que cometeram com o estudo, apontando onde eles encontrariam as respostas para as questões, caso tivessem lido minhas indicações, e as suas falhas no processo de estudo e pesquisa. Ao final de toda a explicação e indicação das falhas de atenção, atendi alguns alunos em particular porque percebi que eles precisavam de um feedback mais pessoal. Apesar de eu, na minha versão de "professora tradicional" ter ficado bem frustrada, como professora pesquisadora decidi elaborar outro Estudo Dirigido valendo nota para que eles pudessem 
retificar a aprendizagem ${ }^{37}$. O resultado geral nessa nova oportunidade que eles tiveram foi bem melhor, média 6,7.

Voltando à descrição das atividades em ordem cronológica, após o Estudo Dirigido iniciei a missão de construção da roleta (item 25, do quadro 6). Essa foi outra tentativa que fiz de juntar a ideia do lúdico, enquanto jogo mesmo, e aprendizagem de um conteúdo escolar. Agora, no entanto, eles que teriam de construir o jogo. Os alunos dessa idade costumam criar com papéis coloridos joguinhos de escolha de cor ou de número para abrir e encontrar alguma mensagem que está escondida sob a cor/número. Então, a roleta seria algo semelhante, mas que poderíamos trabalhar substantivos, adjetivos, leitura do livro, produção textual, tudo com arte, criatividade e ludicidade. Alguns alunos foram bem criativos na produção do brinquedo (roleta) em si. Era necessário escolher personagens das lendas brasleiras, presentes nos livros paradidáticos, representálos em desenho e nomeá-los (utilização de substantivo comum ou próprio de acordo com o caso), selecionar características importantes deles (adjetivos) para escrever um pequeno texto descritivo para que o jogador pudesse decifrar quem era o personagem antes de "abrir" e confirmar a resposta vendo o desenho e o nome.

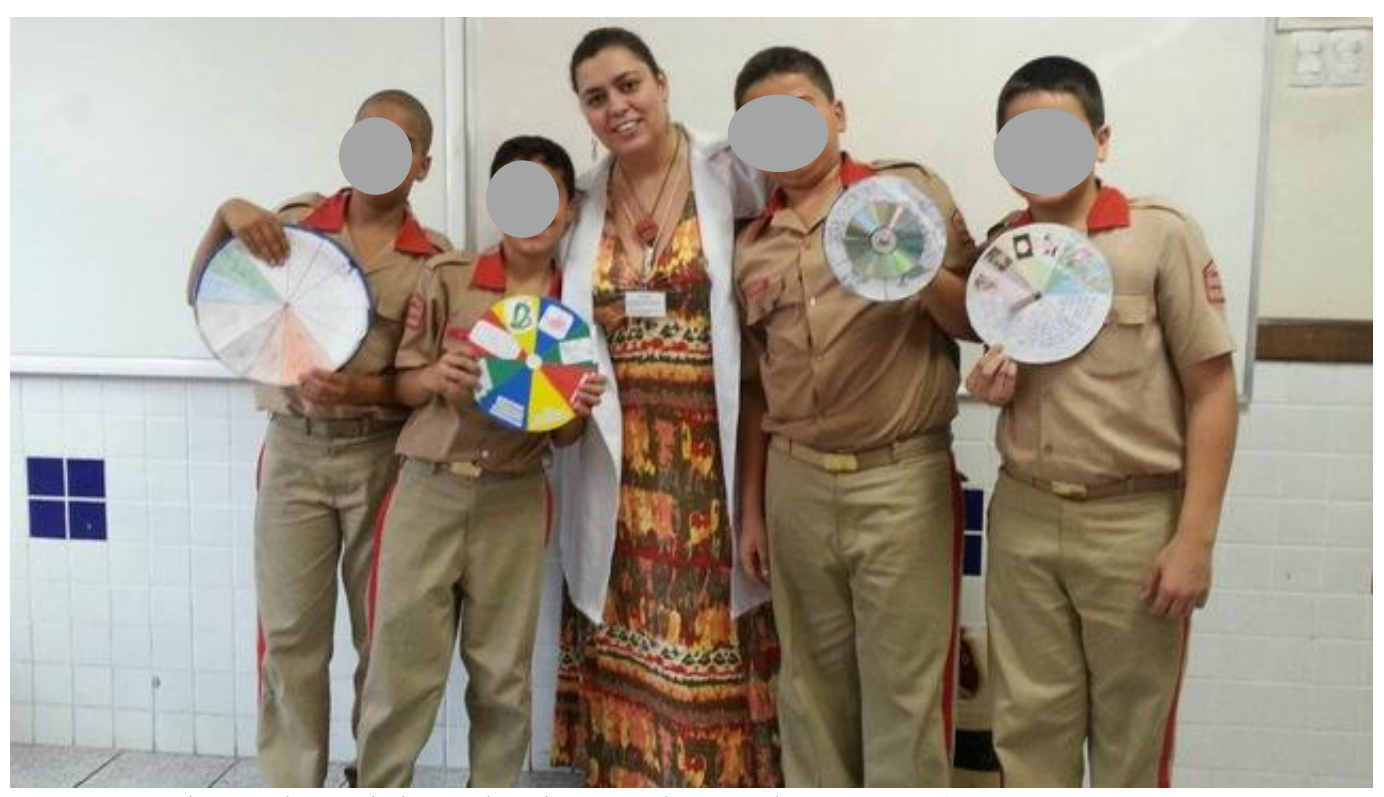

Foto 6: Roletas do Folclore de alguns alunos da Turma A.

\footnotetext{
${ }^{37}$ Isso se deu no que expus no item 32 (quadro 7, "Missões Lúdicas”, partes II, $4^{\circ}$ Bimestre).
} 


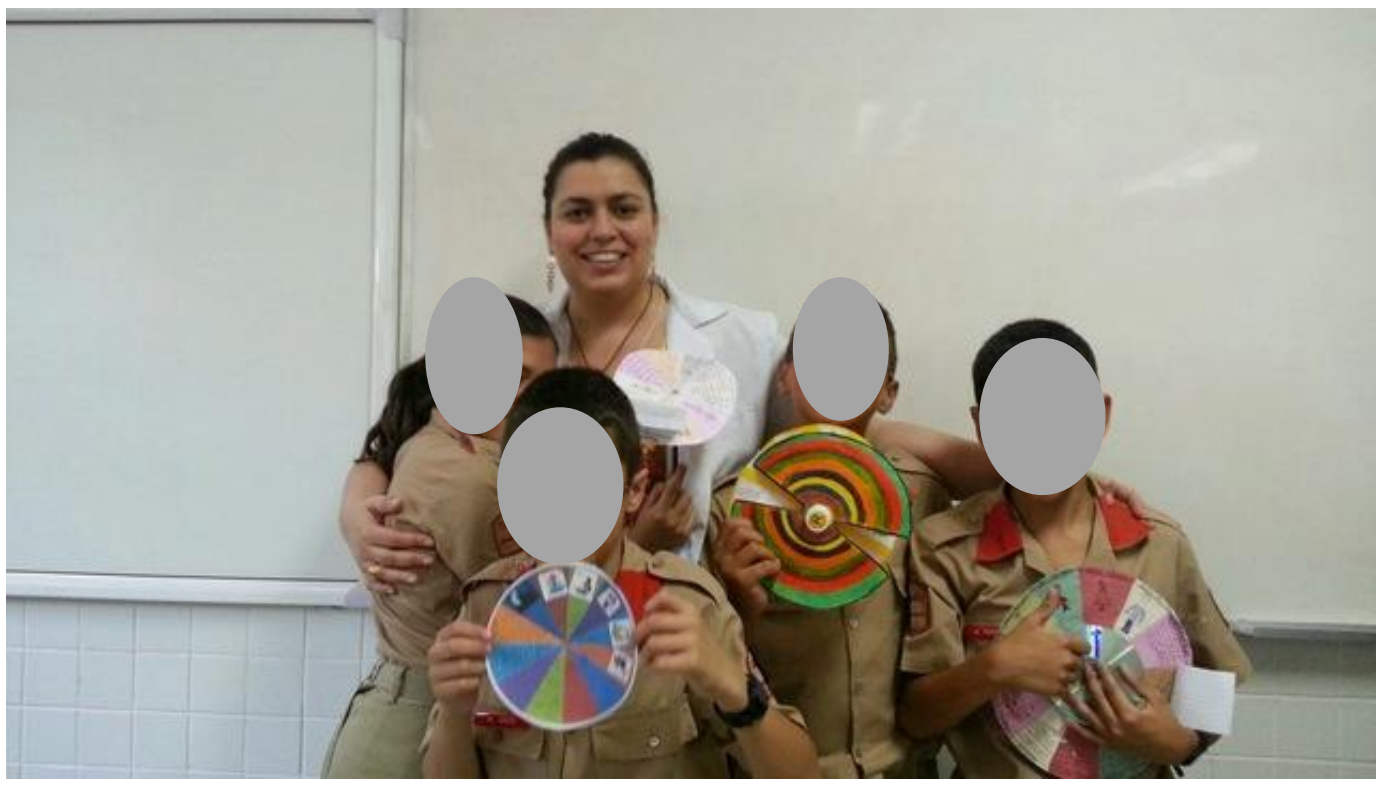

Foto 7: Roletas do Folclore de alguns alunos da Turma A.

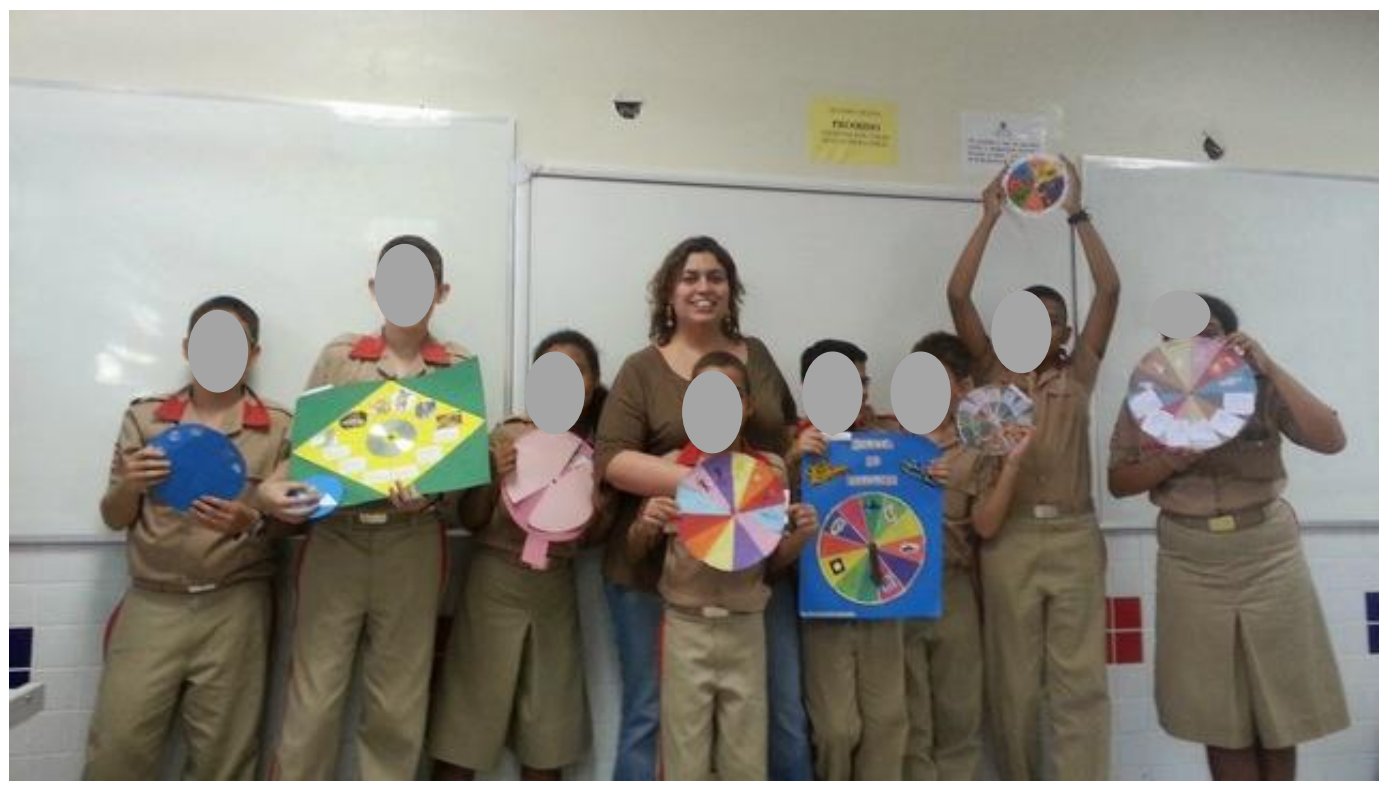

Foto 8: Roletas do Folclore de alguns alunos da Turma B.

Após essas atividades, fizemos a primeira avaliação com base no Estudo Dirigido já descrito anteriormente. Em seguida, introduzi o conteúdo "História em Quadrinhos" (HQ), apresentando vídeos que selecionei no Youtube sobre o assunto. Todas as missões descritas nos itens 28, 29, 31 e 34 (quadros 6 e 7, "Missões Lúdicas", partes I e II, $4^{\circ}$ Bimestre) exploravam conteúdos mais voltados para elementos comuns às HQs: interjeições, onomatopeias e características dos quadrinhos. Foram atividades que poderiam ser realizadas com uma metodologia tradicional explanativa, mas que privilegiou ações individuais e 
em grupos com produção constante por parte dos alunos, além de muita interação alunos-alunos e professora-alunos, nas guildas.

$\mathrm{Na}$ verdade, desde o início do semestre, desenvolvi trabalhos que mesclavam imagens, textos com linguagem mista e/ou não-verbal, para que os alunos percebessem a importância da comunicação e expressão no conjunto e não apenas - principalmente em se tratando de aula de Língua Portuguesa - em textos exclusivos da linguagem verbal, muito mais naturais às aulas dessa disciplina. Esse desenvolvimento culminou no último período com o gênero textual HQ e a aprendizagem de conteúdos relacionadas quase que diretamente a ele, por exemplo, o uso de onomatopeia e interjeições.

(Saio novamente do tempo cronológico para que fique fácil a visualização da construção da aprendizagem dos conteúdos ao longo do bimestre.) Nessas atividades, os alunos tiveram de: a) conhecer, reconhecer e perceber as diferenças entre interjeição e onomatopeia a partir de várias imagens e textos que lhes foram apresentados (missão descrita no item 28, quadro 6); b) criar, coletivamente nas guildas, uma tira de HQ a partir de uma anedota, utilizando todos os conhecimentos já vistos nos vídeos e destacados nas aulas, conforme surgiam nas imagens e tiras apresentadas (item 29, quadro 6); c) transformar, individualmente, mas com uma interação coletiva para haver harmonia no conjunto, um capítulo do livro paradidático do bimestre em formato de HQ (item 31, quadro 7); e d) ilustrar uma cena específica da história do livro para ratificar a aprendizagem de interjeições e onomatopeias (item 34, quadro 7).

A atividade com interjeições e onomatopeias (item 28, quadro 6) foi realizada nas guildas. Como os alunos já tinham visualizado vários exemplos nos vídeos a que assistiram, comecei mostrando-lhes novas construções, com meu iPad, indo de grupo em grupo e conversando sobre as diferenças e usos. Eles mesmos falavam ou perguntavam sobre os casos apresentados. Simultaneamente a esse processo, até porque eu era apenas uma para passar em seis grupos, eles criavam interjeições e onomatopeias para imagens pré-estabelecidas que thes havia entregue no início da aula. As imagens eram bem específicas para que observassem a representação de uma mesma ideia, por exemplo, fome ou raiva, ora por meio de uma interjeição, ora por uma onomatopeia. 
Era necessário também desenvolver a capacidade de transformar um texto só de linguagem verbal em texto de linguagem mista, ou até mesmo não-verbal. Foi isso que fizemos com a produção de uma HQde uma página, a partir de uma anedota presente no livro didático do PNLD (eu fiz a escolha do texto e apresentei aos alunos $^{38}$ ). Esse trabalho foi muito mais complexo do que simplesmente converter falas em onomatopeias e/ou interjeições. Era necessário perceber as partes mais importantes, o que se desejava privilegiar, resumir e/ou conjugar algumas informações para caber em um número de quadrinhos que gerasse uma leitura interessante e não entediante. As produções finais foram bastante ricas e a crítica ao trabalho do outro me chamou muito a atenção.

Depois de prontos eu tinha em minhas mãos doze tirinhas. Em uma aula fiz circular essas criações nas seis guildas de cada turma para poderem se autoavaliar e visualizar o que havia nos outros trabalhos que eles não fizeram no deles, o que tinham conseguido melhor que o dos colegas, o que os outros conseguiram representar melhor que eles ou vice-versa. A proposta, no entanto, foi quase toda invertida pelos alunos, que preferiram apontar os erros dos colegas, e não perceber os seus próprios erros. Isso gerou uma questão que levantei para discussão: já que os grupos estavam rindo dos erros dos outros, "qual seria a 'cereja' do meu bolo?", isto é, cada guilda tinha de mostrar a mim e aos colegas o que havia no trabalho deles que o destacava como muito melhor do que os outros para que pudessem ridicularizar e criticar a produção alheia. Poucos alunos tentaram mostrar um ou outro elemento bem desenvolvido a ponto de fazer do seu trabalho algo melhor do que os dos colegas. Talvez o não êxito dessa proposta estejalá no início, quando sedesencadeouuma competividade entre grupos (competitividade essa que comumente existe na escola e é naturalmente destrutiva), pois, assim agindo, as guildas usaram o ataque ao outro como mecanismo de defesa para os pontos fracos de suas próprias produções.

Transcrevo abaixo a anedota que gerou as HQs de uma página. Em seguida, apresento quatro das doze produções.

\footnotetext{
${ }^{38}$ Aliás, é importante destacar que o livro didático (LD) adotado na escola e dado aos alunos para uso durante o ano letivo faz parte do Programa Nacional do Livro Didático (PNLD) e é mais uma ferramenta que pode auxiliar o professor, mas, muitas vezes, engessa o trabalho. Minhas aulas nunca ficam presas à estrutura e à ordem desse material. Costumo escolher um ou outro texto para lermos, um ou outro exercício para gerar uma ratificação de aprendizagem por meio da repetição (como destaca Macedo, 1999 p. 4). Mas não faço uma aula somente com o livro.
} 
Márcio chega em casa e diz:

- Pai, tenho uma ótima notícia pra você!

- O que é? - perguntou o pai.

- Você não me prometeu uma bicicleta se eu passasse de ano?

- Sim, meu filho.

- Então se deu bem. Economizou um dinheirão! $!^{39}$

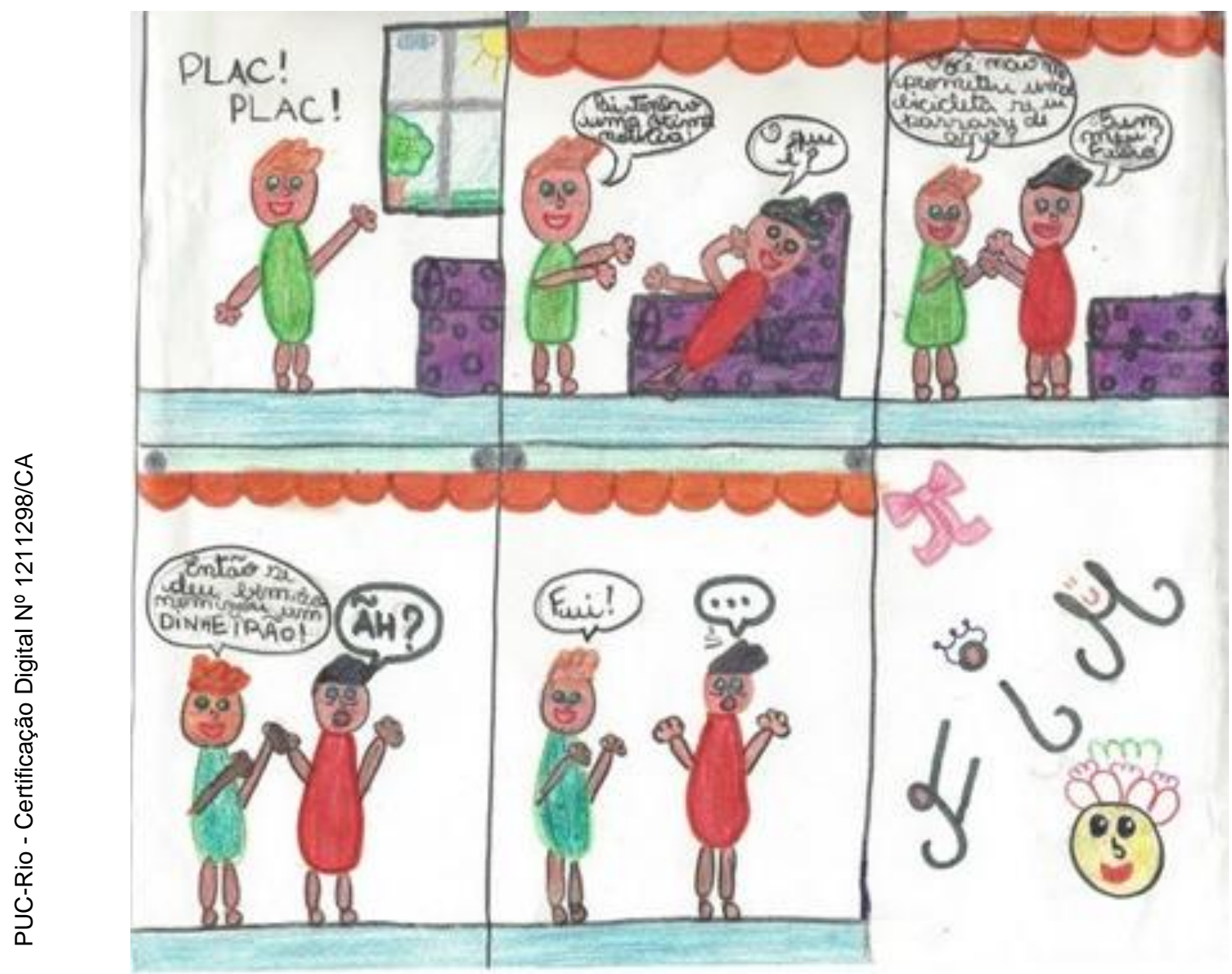

Figura 14: HQ a partir de anedota produzida por uma guilda.

${ }^{39}$ Paulo Tadeu. Proibido para maiores - As melhores piadas para crianças. São Paulo: Matrix, 2007, p. 8. In: CEREJA, W. R. E MAGALHÃES, T. C. Português: Linguagens. $7^{a}$ ed. reform. São Paulo: Saraiva, 2012, p. 61. 


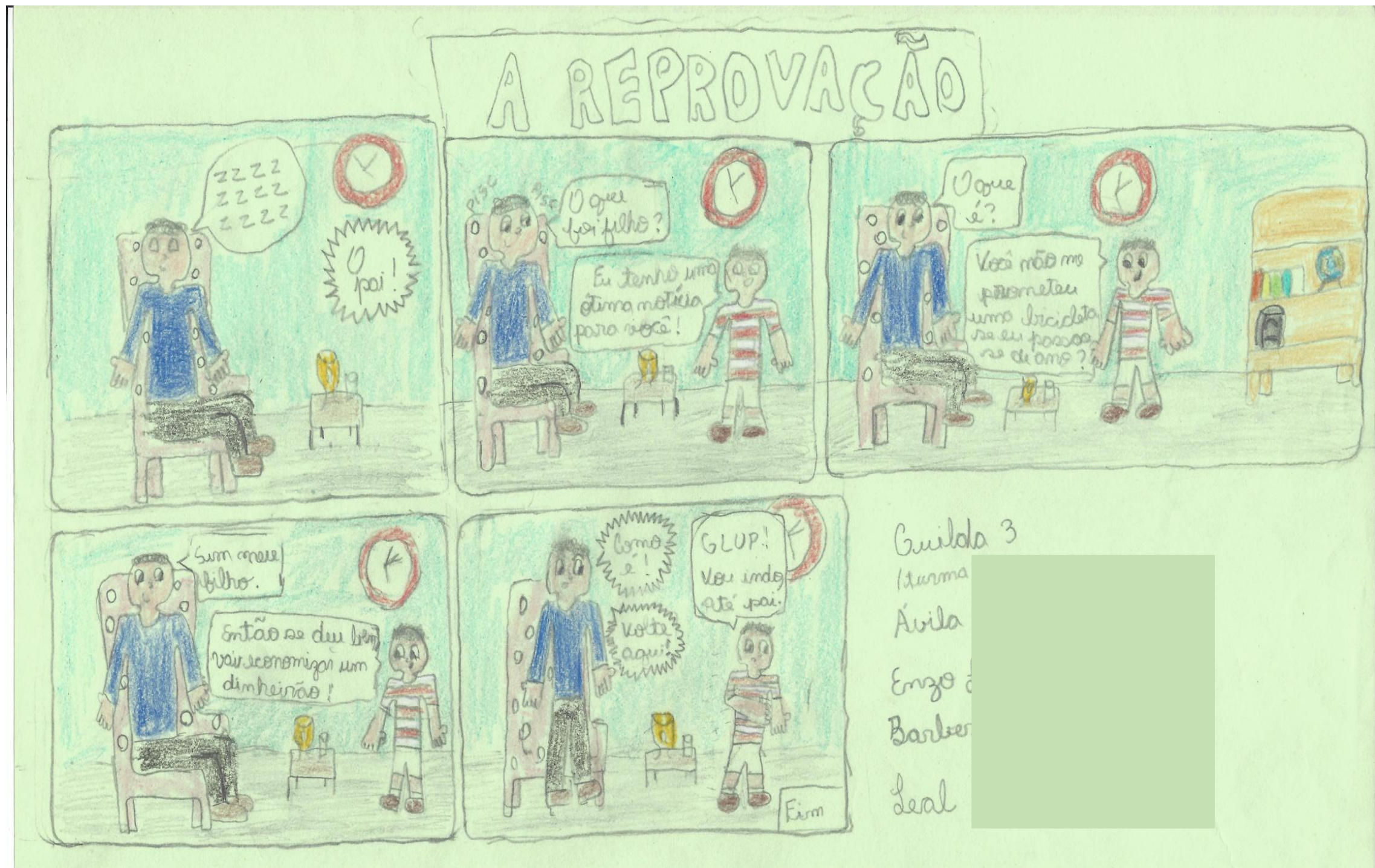

Figura 15: HQ a partir de anedota produzida por uma guilda. 


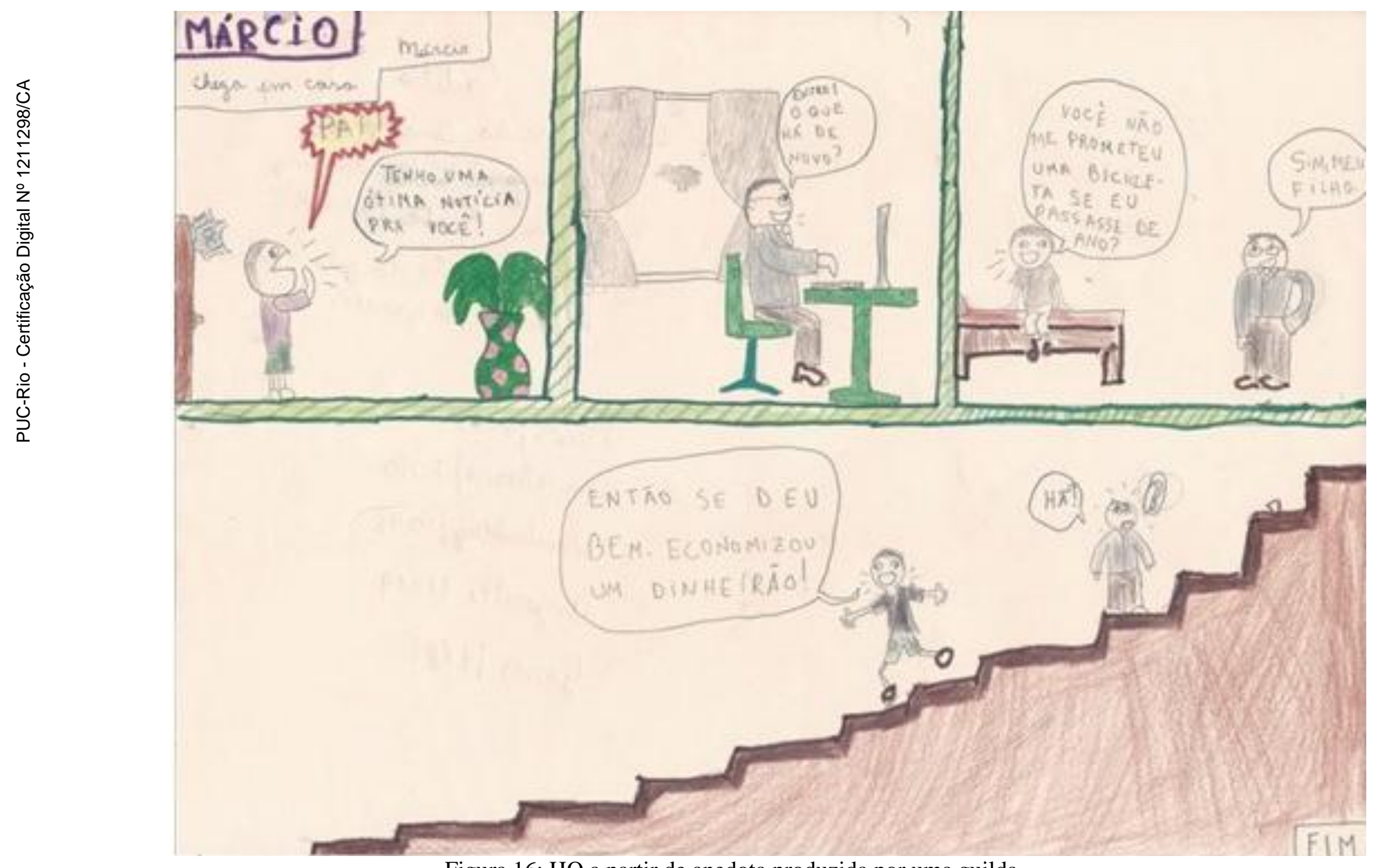

Figura 16: HQ a partir de anedota produzida por uma guilda. 


\section{A REPRO AÇÃO}
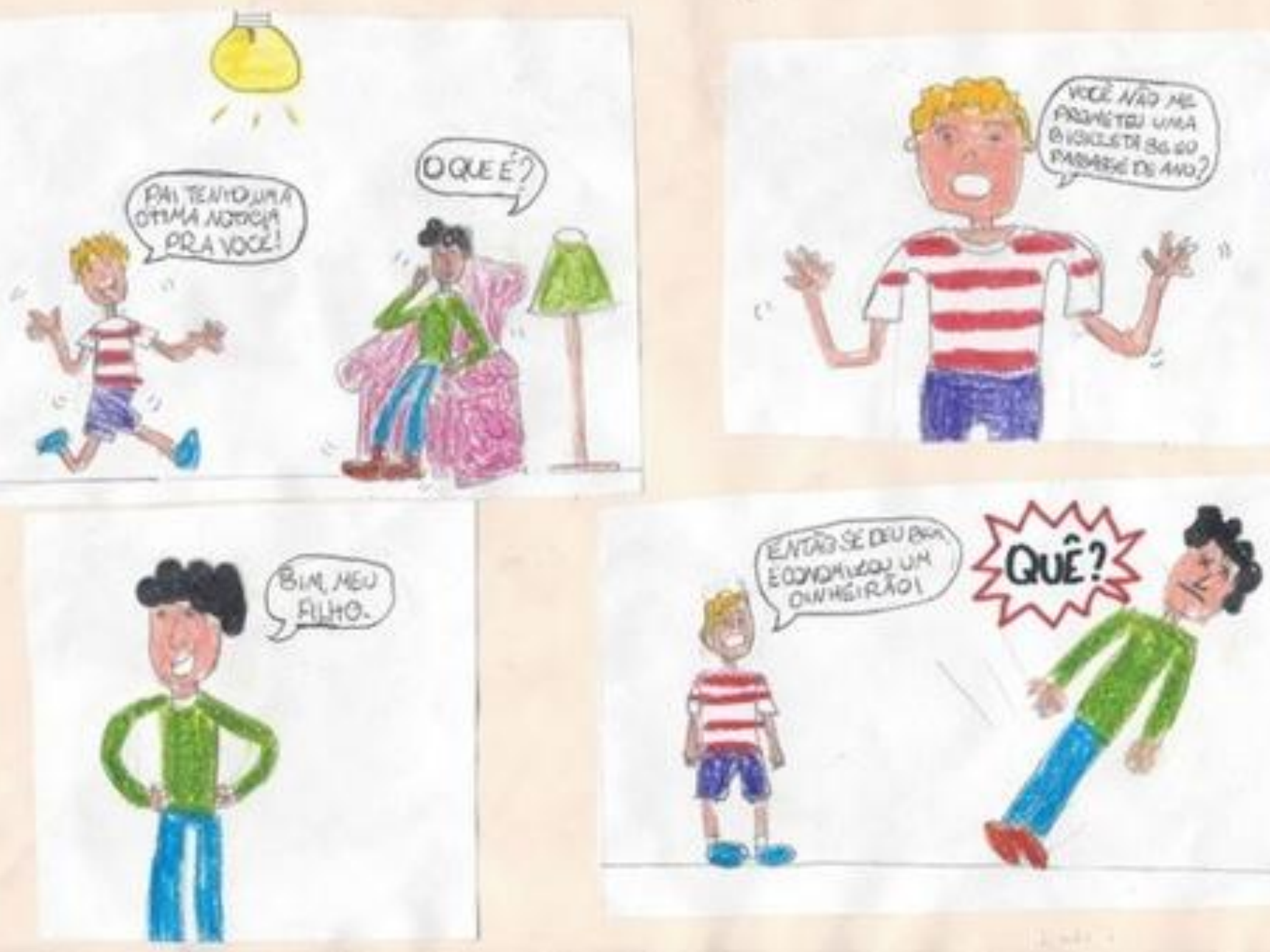

Figura 17: HQ a partir de anedota produzida por uma guilda. 
Percebendo as dúvidas e dificuldades dos alunos em desenvolver a sua parte da HQ de acordo com o que havia sido proposto na atividade de produção de HQ de um capítulo do livro paradidático (item 31, quadro 7), realizei algumas aulas práticas de transformação de trechos dos capítulos lidos em quadrinhos (cada aluno ia fazendo o seu capítulo e eu ia orientando, auxiliando alunos e grupos). Elaborei, no entanto, uma atividade comum a todos para sanar problemas que estavam se repetindo em várias situações. Essa atividade foi a ilustração de um trecho específico do livro ${ }^{40}$ (item 34 , quadro 7), para que todos apresentassem divisões claras em quadros, com o uso apropriado de interjeições e onomatopeias, principalmente, mas com a possibilidade de também explorar a aprendizagem do uso de letra, balões e os demais elementos do gênero textual.

A seguir, exponho algumas tiras com enfoques distintos. Os alunos tiveram liberdade na criação e no uso do trecho apresentado, desde que representassem por onomatopeias e interjeições o acontecimento presente no último parágrafo.

${ }^{40}$ Para conhecimento, o trecho utilizado está transcrito no Anexo 6. 

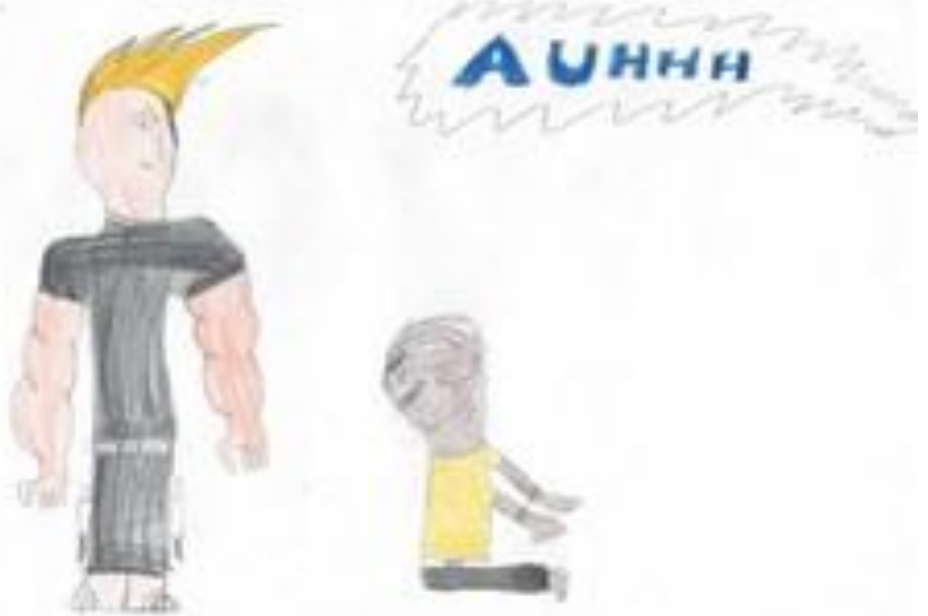

ل)
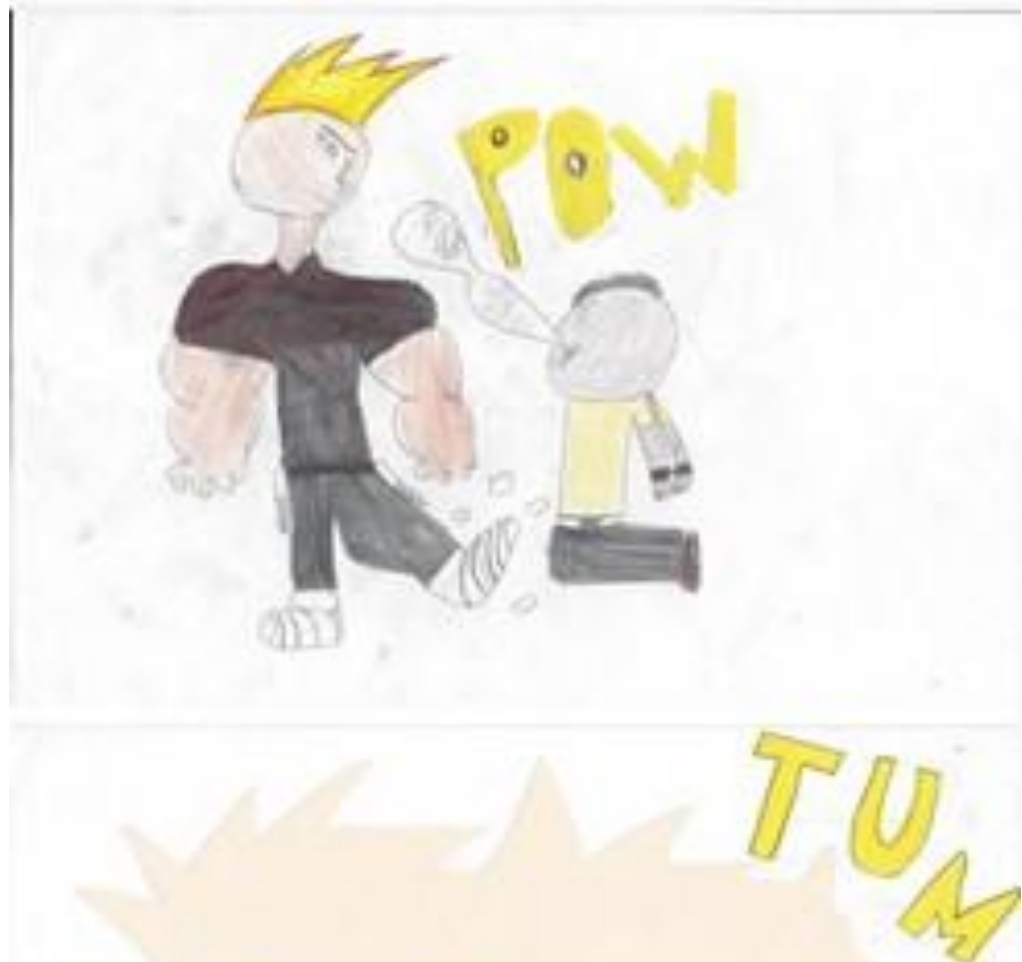

Figura 18: Tira de HQ a partir de trecho do livro paradidático produzida por uma guilda. 


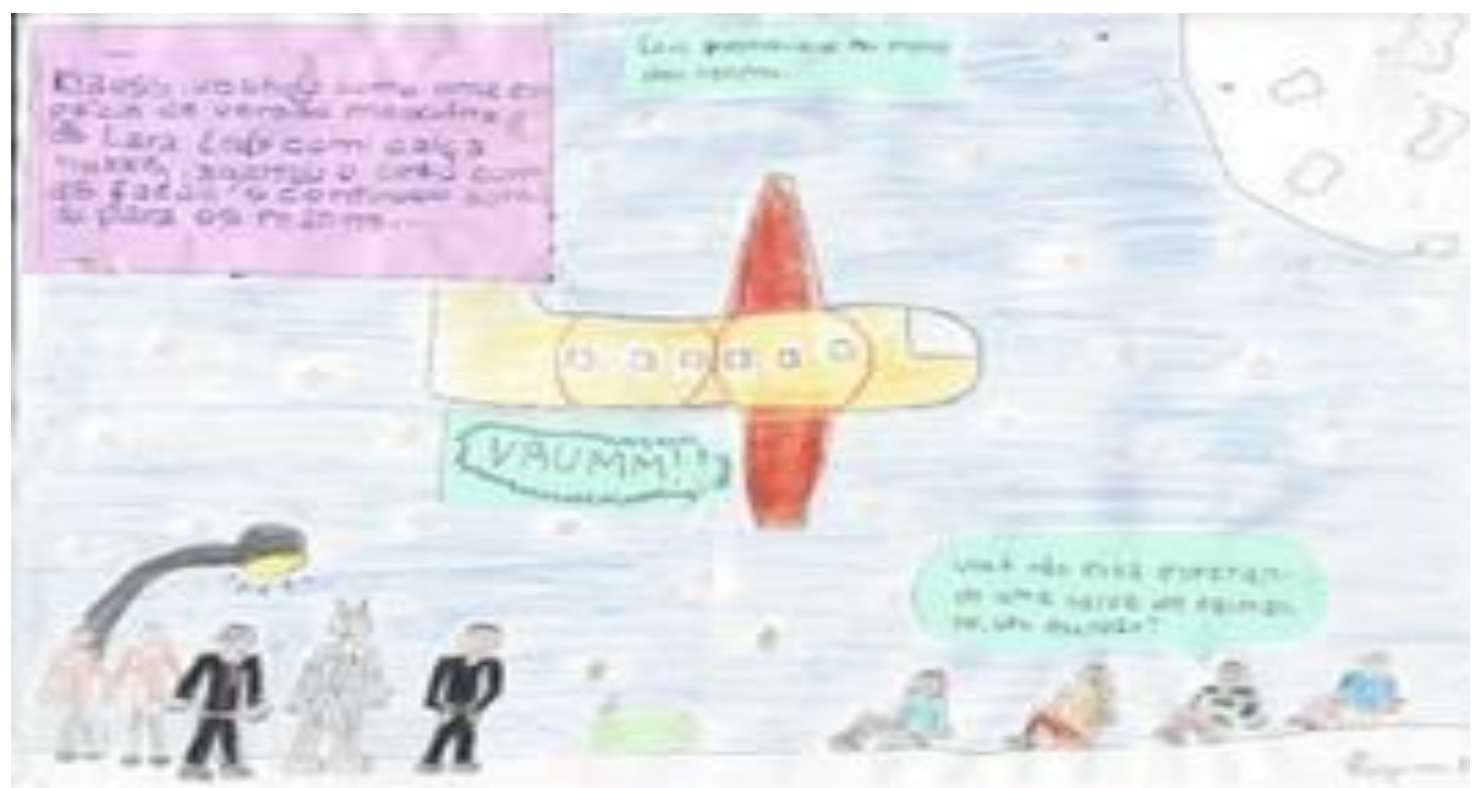

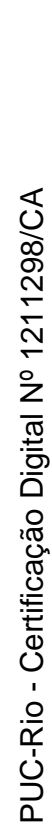

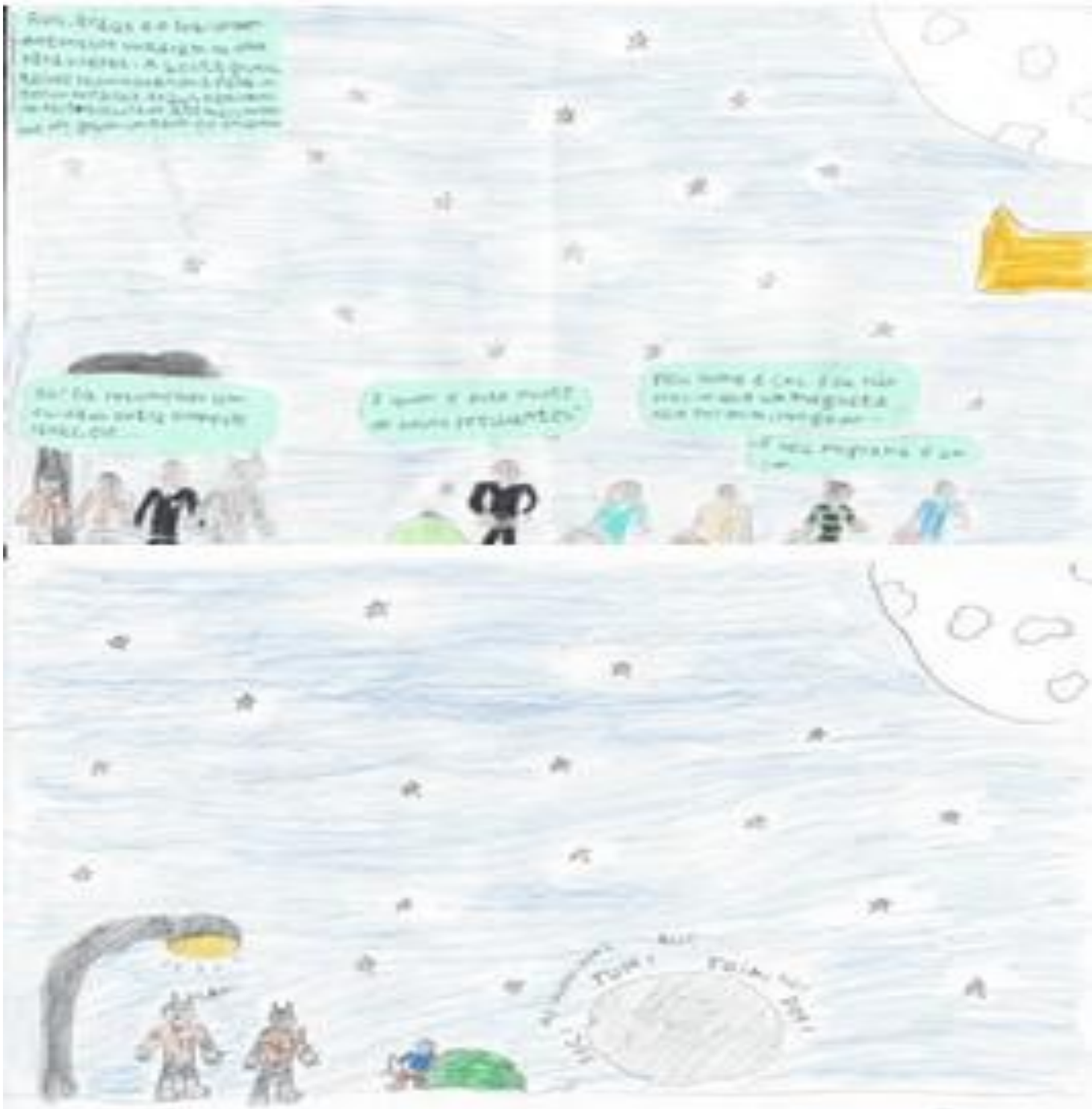

Figura 19: Tira de HQ a partir de trecho do livro paradidático produzida por uma guilda. 


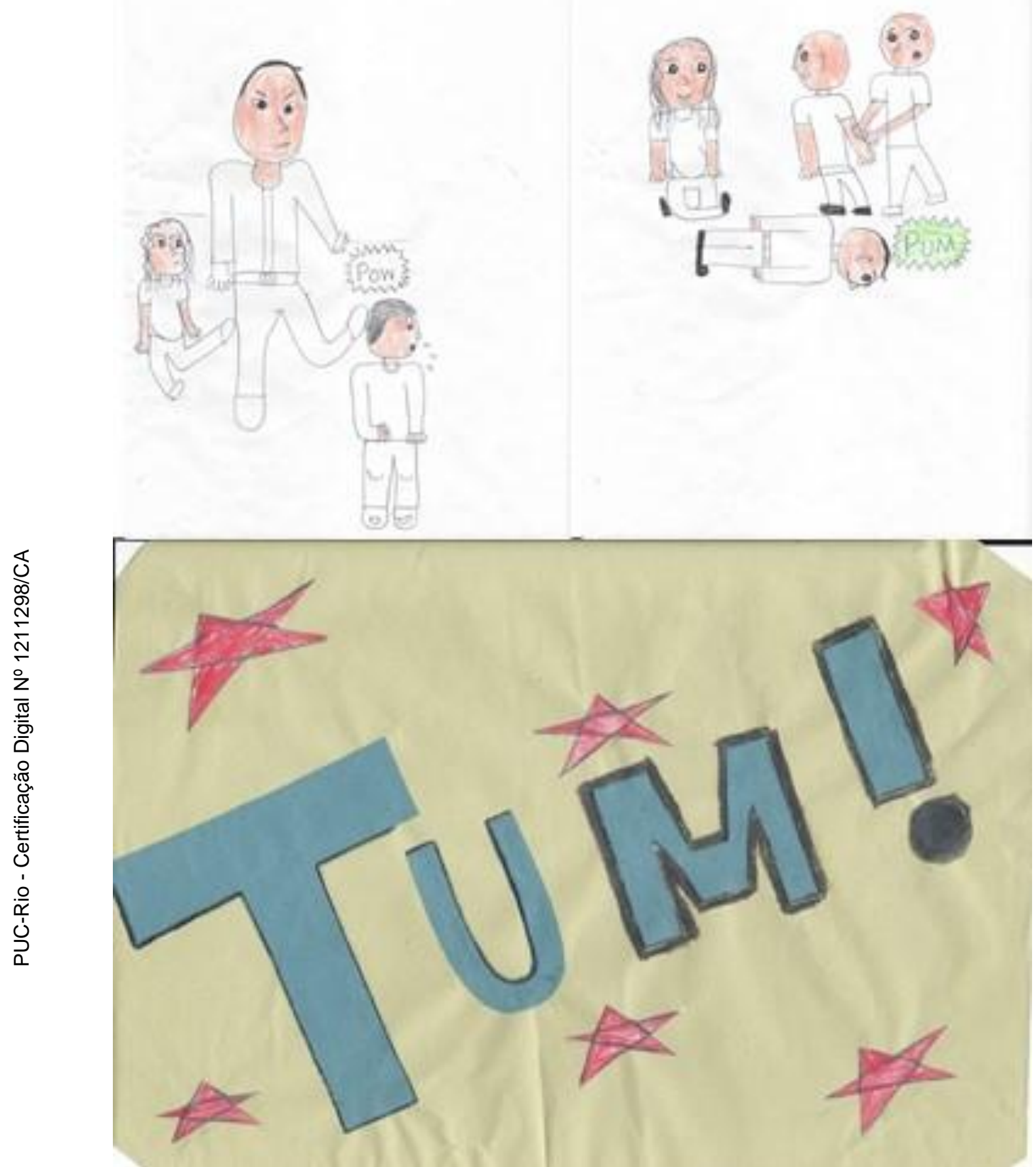

Figura 20: Tira de HQ a partir de trecho do livro paradidáticoproduzida por uma guilda.

No meio desse processo de construção de $\mathrm{HQ}$, foi realizada a segunda avaliação a partir do Estudo Dirigido sobre o Artigo (item 32, quadro 7), já relatada anteriormente. $\mathrm{O}$ alunos também produziram em seguida um texto de opinião em que expuseram seus sentimentos e emoções a respeito das despedidas 
e mudanças, comuns a alunos do CMRJ. Na verdade, o SCMB tem uma característica peculiar: um terço de seus alunos entram e saem do colégio todos os anos devido às transferências de seus pais militares.Com isso, as despedidas são constantes.

A proposta temática para essa redação surgiu quando percebi que algumas alunas (especificamente meninas) já estavam começando a trocar dedicatórias em seus cadernos mostrando o quanto se amavam ("best friends forever", como costumam escrever) e como seria dura a separação. Constateiainda que os alunos concursados não tinham essa percepção, pois eles entraram, a princípio, para ficar até o final do Ensino Médio no colégio. Além deles, grande parte dos meninos, filhos de militares que também vivem essas transferências em suas vidas, ainda não tinham se dado conta do que estava por vir. Talvez, seja algo mesmo voltado para o lado mais falante e sentimental de desenvolver as amizades, quem sabe natural do gênero feminino.

No meio disso tudo e mais para o finalzinho do bimestre, realizamos outra (auto)avaliação com o preenchimento de nova ficha semelhante à do terceiro bimestre, mas com os conteúdos e atividades realizadas no quarto. Fizemos também a construção da memória do ano (item 37, quadro 7). Peguei uma folha de papel ofício branca, dobrei em quatro partes formando uma espécie de cartão com capa. Mostrei a eles que deveriam fazer o mesmo e escrever em cada parte suas memórias dos bimestres. Depois, na capa, deveriam ilustrar como quisessem e colocar nome, número e turma. Essa atividade foi bem "falante", pois a todo instante eles se perguntavam em voz alta, pergutavam a mim e aos colegas alguma coisa sobre o ano, como, por exemplo, que livros tinham lido em cada bimestre (eles lembravam bem dos dois que haviam adorado, mas poucos recordavam dos primeiros), os nomes de alguns professores, os passeios que tinham feito etc. A pergunta de um lembrava ao outro alguma coisa e assim eles iam se comunicando e construindo a memória. Eu me mantive calada observando para não influenciálos nas lembranças. Queria ver se as atividades tinham sido marcantes ou não, sendo lembradas e mencionadas por eles sem a minha interferência. Falei apenas quando a pergunta era feita diretamente a mim sobre algo específico, como nomes de professores, datas, lugares etc. 
Um ponto que me chamou atenção nessa observação da atividade foi o fato de eles se aperceberem da grande troca de professores pela qual passaram. Vários fizeram comentários orais negativos, demonstrando sequer saber o nome de alguns professores porque pouco os conheciam.

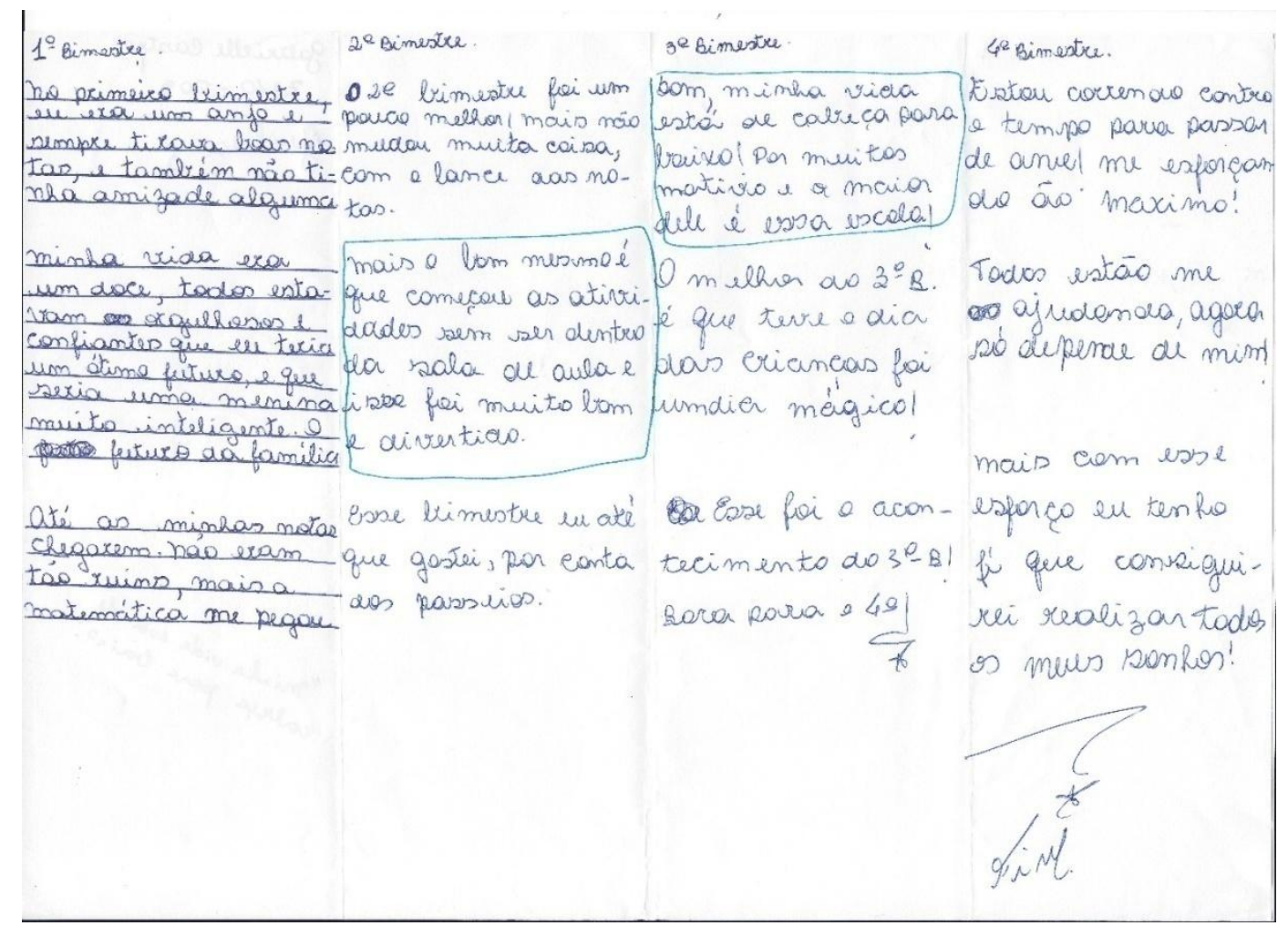

Figura 21: Exemplo da atividade de Memória do Ano, AutorA35.

Encerramos o bimestre para o início da semana de AE com uma roda de despedida, promovendo uma última interação com a produção de bilhetes de lembranças e despedidas a serem trocados por eles ${ }^{41}$.

\subsubsection{Missões culturais extracurriculares: e a escola sai da escola}

Concomitantemente às "Missões Lúdicas" do quarto bimestre, elaborei um projeto extracurricular, com atividades em caráter facultativo, que envolvia a família ${ }^{42}$. Acredito, sinceramente, que a "escola para todos" precisa ultrapassar os muros da sala de aula e investir na família como parte fundamental na formação

\footnotetext{
${ }^{41}$ Esse momento faz parte do quadro de atividades complementares, exposto neste mesmo capítulo, mais a frente, na página 130.

${ }^{42}$ Para se tornar mais clara a compreensão das missões culturais, incluirei aqui produções de alunos já tecendo alguns comentários sobre elas.
} 
cultural da criança. A formação integral e acadêmica, hoje, do aluno dessa escola para todos - principalmente daquele que não recebe naturalmente em casa oportunidades para seu desenvolvimento, simplesmente, porque os pais também não tiveram acesso a uma formação de qualidade - implica numa construção social escolar muito maior que os duzentos dias letivos fechados entre quatro paredes apenas, praticamente,entre professores e alunos.

Nesse projeto, eu propunha semanalmente uma atividade cultural, tentando abranger diversos gêneros de eventos (filme, música, teatro, exposição, dança etc., mesmo que fosse apenas assistir a um vídeo em casa, pois tive de criar possibilidades para todos os bolsos). Os alunos tinham de realizar a atividade, fotografar algo para apresentar aos colegas e escrever uma resenha crítica sobre a experiência em si que seria lida na turma para o desenvolvimento também da oralidade. Foram cinco missões ao todo. São elas: 


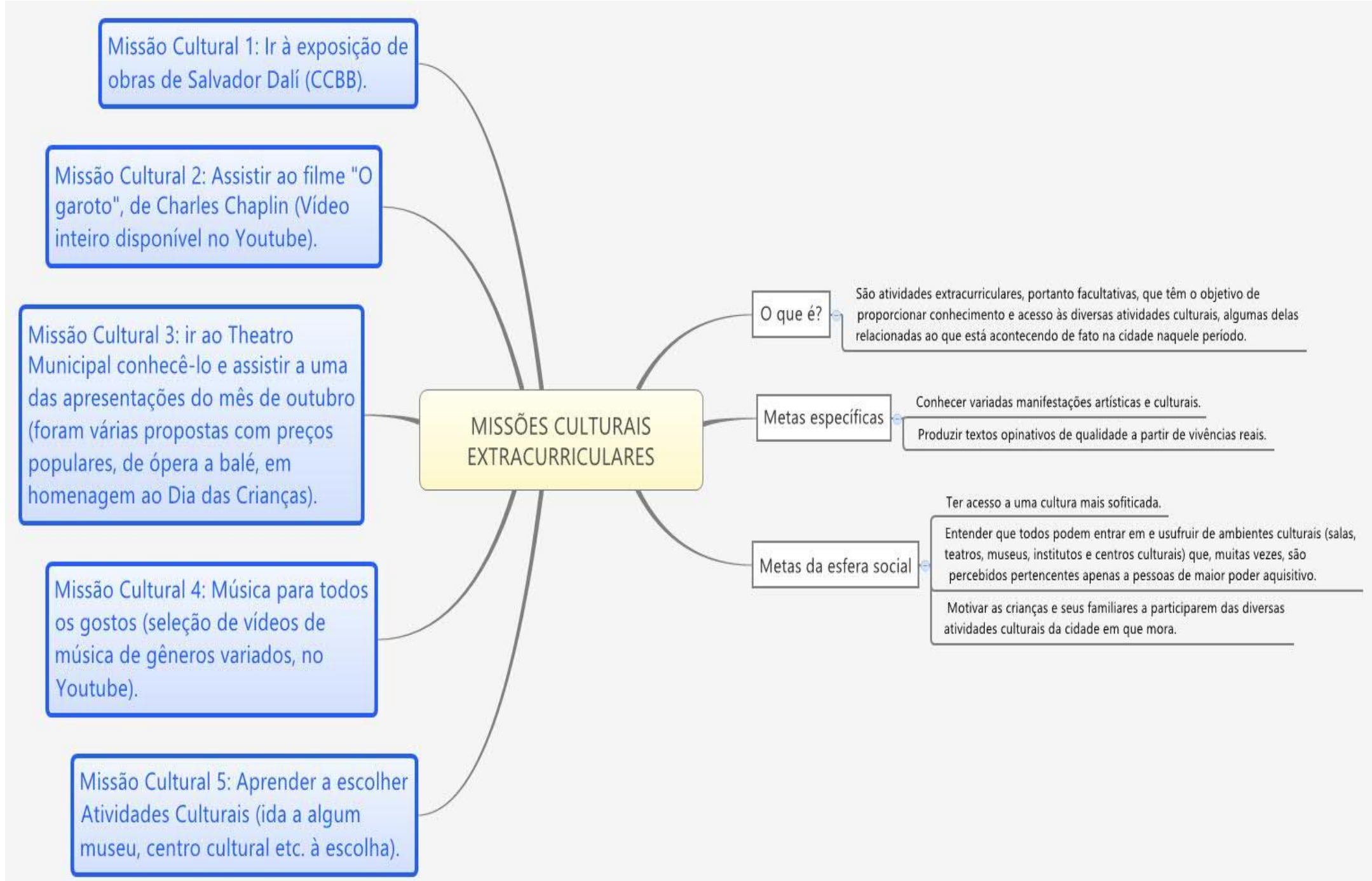

Quadro 12:Panorama geral das missões culturais, com quadro explicativo. 
As propostas não tinham exigência alguma de observação específica. Eu queria apenas criar oportunidades para as crianças terem acesso a uma boa cultura e a lugares pouco frequentados por eles e seus familiares. Ademais, tinha o objetivo de também promover a escrita significativa.

Como eram facultativas, essas atividades foram realizadas, de forma completa, por poucos alunos. A contagem que apresento é pelo número de resenhas que recebi. No entanto, muitos realizaram, em parte, as missões, principalmente as que não dependiam dos responsáveis para sair de casa. Isto é, fizeram, por exemplo, comentários em sala de que haviam assistido aos vídeos no Youtube. Vários disseram ter gostado e procurado outros vídeos relacionados, mas não quiseram relatar por escrito.

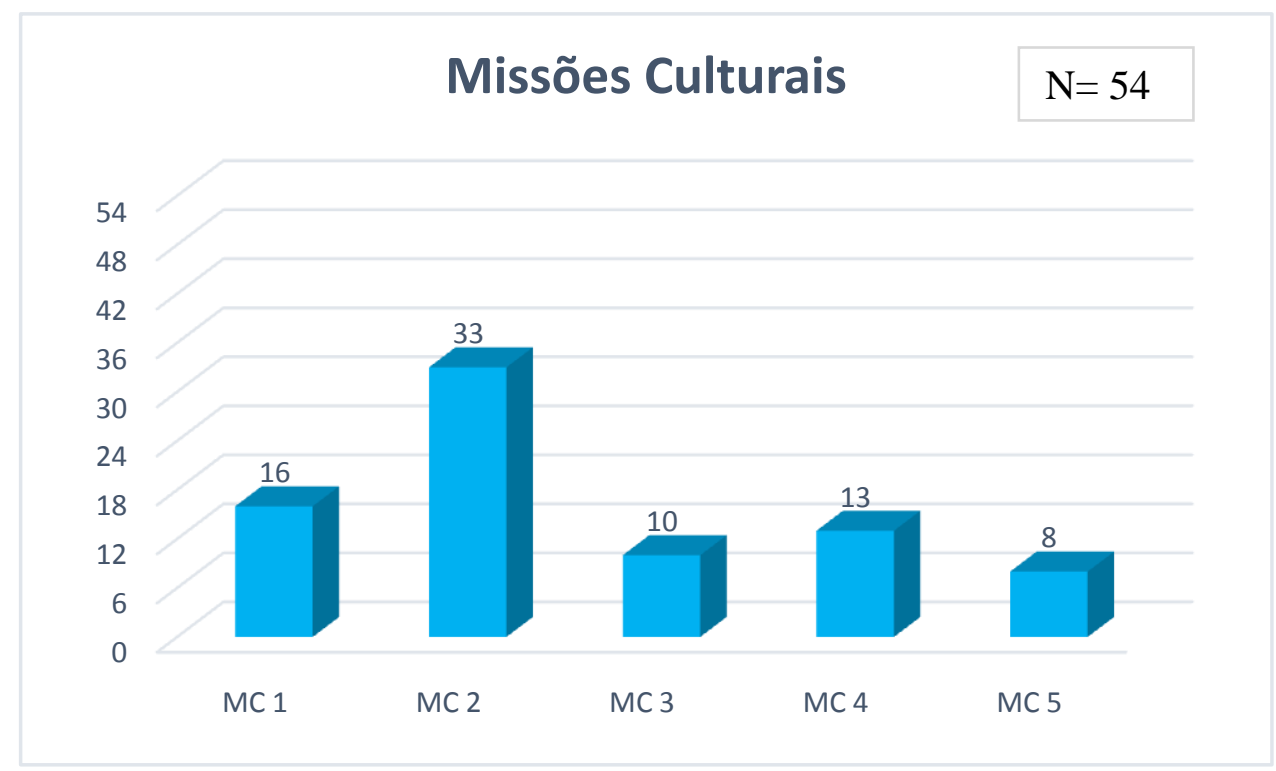

Gráfico 6:Apresentação do quantitativo de alunos que realizaram cada Missão Cultural.

Percebi, na apresentação da primeira missão (MC1), um esforço de muitos em realizá-la, mas fatores externos, relacionados ao tempo das famílias e distância para se locomoverem, impediram. Talvez por isso tenhamos logo na segunda missão (MC2) o recorde de participação, pois podia ser feita em casa, e o menor número na última (MC5), que também exigia deslocamentos.

No que diz respeito ao quantitativo de participação nas missões, temos: 


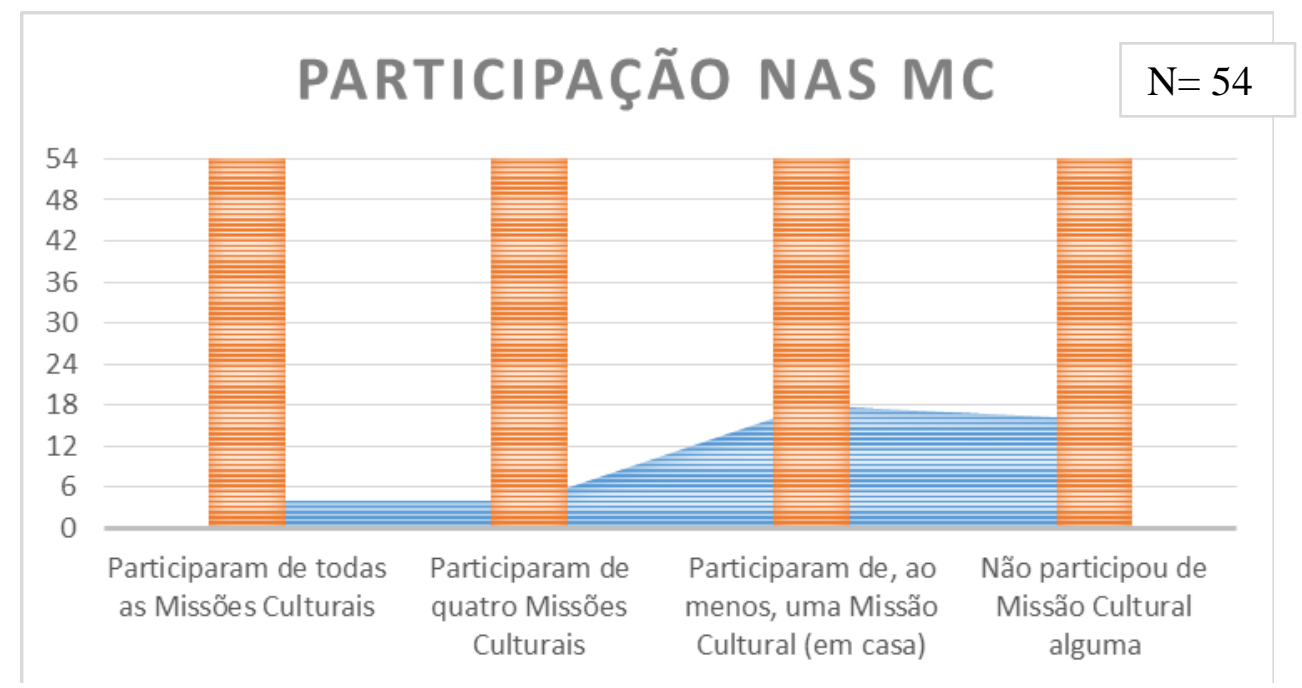

Gráfico 7: Apresentação da participação ou não dos alunos nas Missões Culturais

Considero importante destacar que dos cinquenta e quatro alunos, dezesseis não escreveram sobre Missão Cultural alguma. Desses dezesseis, a metade exata foi reprovada ao final do ano letivo e uma aluna desse grupo já estava fazendo o sexto ano pela segunda vez no SCMB por reprovação por nota ${ }^{43}$.Não sei até que ponto posso fazer uma relação entre a reprovação e o investimento e participação familiar na formação integral do aluno, mas não consigodeixar de enxergar isso que se aponta nesses números. Será que esses oito alunos reprovados desse grupo de dezesseis estão sozinhos em sua caminhada escolar? Até que ponto a família é parte fundamental na formação escolar da criança para que ela expanda seu repertório cultural e adquira recursos básicos para o desenvolvimento de sua aprendizagem?

Sobre a ida ao CCBB para ver a exposição de Salvador Dalì, dois alunos me surpreenderam com a oportunidade que tiveram de experimentar outras atividades culturais. AutorB5 $5^{44}$ aproveitou o momento para ver outras exposições como a que é fixa da casa sobre as moedas:

Vimos muitas exposições de vários artistas, eram todas geniais, observamos também as moedas e notas decorrentes em cada país, reparei que antigamente, o troco era bala, eu gostaria de viver nesta época. (...) Eu gostei de ter ido ao centro cultural Banco do Brasil, pois fiquei confortável lá dentro. (AutorB12, grifo meu)

\footnotetext{
43 Destaco a reprovação por nota, porque outros dois alunos desse grupo estavam cursando o $6^{\circ}$ ano pela segunda vez por reprovação voluntária para entrar no CMRJ.

${ }^{44}$ A partir daqui e, principalmente nos dois próximos capítulos (seis e sete) destinados à discussão da pesquisa, aparecerão diversas transcrições dos textos dos alunos ao longo do semestre. Todas essas transcrições se mantêm exatamente igualao original do aluno, com os diversos erros e problemas, sem que eu os aponte indicando "sic".
} 
AutorB27 pôde ir ao teatro no $\mathrm{CCBB}$ e ela mesma relata que nem se lembrava mas como era isso:

O museu parecia com prédios antigos com muitos andares, o que eu mais gostei foi da peça de teatro que tive a oportunidade de ver, eu nem me lembrava mas de como era uma. (AutorB27, grifo meu)

A Missão Cultural mais aproveitada, quantitativamente falando, foi a do filme de Charles Chaplin. AutorB45 diz ter assistido ao filme acompanhada:

E falando sobre o filme * é uma coisa legal por que eu vi o filme com a minha avó e minha irmã de 6 anos e nós caímos na gargalhada. (AutorB45, grifo meu)

Novamente a aluna AutorB27 me surpreende com o que relata:

(chorei muito!) No geral achei impressionante o fato de nós nunca termos ouvido falar em clássicos como este. (AutorB27, grifo meu)

Perguntei a ela quem nunca tinha ouvido falar desses clássicos e ela afirmou que ninguém da casa dela havia visto um filme mudo e em preto e branco antes. Indaguei, então, se alguma outra vez ela já tinha visto a imagem de Charles Chaplin e ela disse achar que nunca antes.

Um aluno que não assinou seu texto - e hoje não consigo identificá-lo sem risco de cometer um erro de autoria - fez um comentário bastante favorável, ao final, sobre o filme "O Garoto", a respeito das Missões Culturais (aparece iluminado em amarelo):

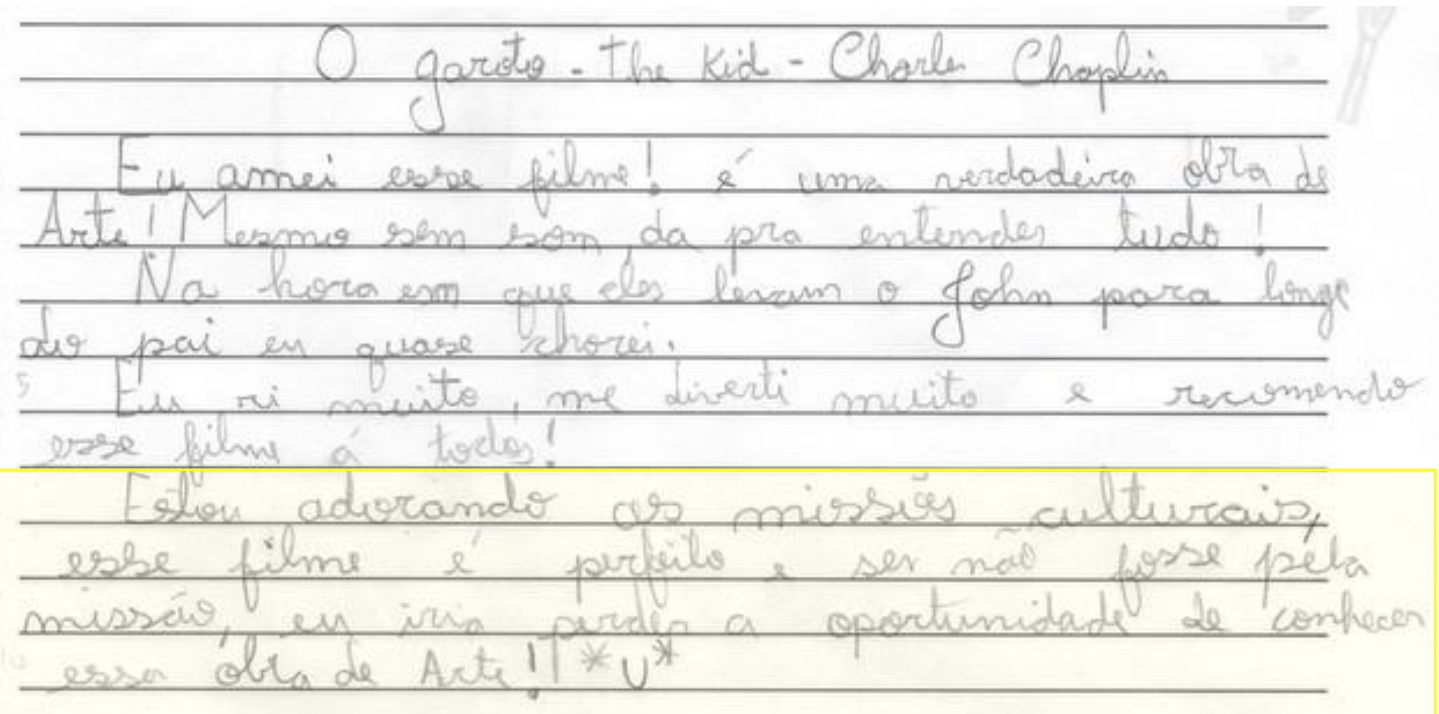

Figura 22:Opinião de aluno sobre filme "O garoto" - Missão Cultural.

A ida ao Theatro Municipal teve seus encantos e desencantos. Não posso negar que algumas das apresentações, apesar de dirigidas especificamente às crianças no mês de outubro, exigem um preparo maior para serem realmente 
"degustadas". Alguns alunos representaram bem isso quando comentaram sobre o espetáculo teatral musicado, com coral e orquestra sinfônica, "O Pequeno Príncipe", ter uma parte "chata":

Fiquei encantado como o teatro municipal, que é muito lindo. Suas janelas com lindos vitrais que são verdadeiras obras de arte.

Na primeira parte, o espetaculo foi monoto. Não vou negar, dormi. (...)

A segunda parte do espetaculo foi mais dinâmica, marcada pela grande lição de moral narrada pela personagem da raposa, que infatizou a importancia de cativar a outra pessoa. (AutorA21, grifos meus)

Quando o espetáculo começou eu achei muito parado, mas depois eu começei a gostar, porque o pequeno príncipe começou a viajar para vários planetas,. Em cada planeta tinha um morador apenas, e eu ficava curioso para saber qual seria o personagem do planeta seguinte. (AutorA46, grifo meu)

A peça do Pequeno Príncipe, foi muito divertida, estava dividida em 2 atos com intervalo. No primeiro ato foi monótono, começou com um homem explicando como os adultos não o entendiam quando era criança (...) (AutorA26, grifo meu)

Ao final de sua redação, AutorA21 relatou uma crítica interessante mesmo para quem não tem o costume de frequentar espaços culturais (e é assim que as aprendizagens de cidadania, respeito, educação vão se construindo e se fortalecendo como princípios):

O único fato lamentavel, foi a falta de educação de algumas pessoas que aproveitaram o intervalo para sentarem nos lugares das outras, criando tumulto na volta para a segunda parte. (AutorA21, grifo meu)

Três alunos afirmaram ter sido a primeira vez que entraram no Theatro

Municipal, sendo que um deles teve a oportunidade de fazer uma visita guiada:

Quando fui pela primeira vez ao Theatro Municipal do Rio de Janeiro, no dia 15/10/14, não consegui assistir a ópera de "João e Maria”, pois esgotaram-se os ingressos. Para aproveitar o momento, fiz com minha mãe uma visita guiada, que falou sobre a história do Theatro e sua grande reforma. Fui informado que foi utilizado em sua restauração 250 mil folhas de ouro. Nesse dia ainda aproveitei para comprar o ingresso para assistir a Orquestra Sinfonica de "O Pequeno Príncipe". (AutorA42, grifo meu)

Hoje dia 18 de outubro, fui ao Theatro Municipal ver a Orquestra Sinfônica do Pequeno Príncipe.

Foi a primeira vez que fui ao Theatro Municipal, achei muito interessante, as obras magníficas e o encanto da sinfonia. Já tinha lido o livro do Pequeno Príncipe, mas não tinha prestado muita atenção no decorrer da história. Com a música, parece que ficou diferente, mais harmonioso. (AutorA52, grifo meu)

O aluno AutorB34, um dos quatro que realizaram todas as missões culturais, sempre apresentou textos críticos impecáveis. Com uma letra e organização textual acima da sua faixa etária, relatou quase em todas as atividades 
extracurriculares não ter abertura nem interesse (isso ele confirmou em conversa direta comigo) para desenvolver um gosto por uma cultura mais sofisticada, no que diz respeito a visitas a exposições e idas a teatros (lógico que, em se tratando especificamente de ballet clássico, sua crítica negativa é naturalmente aceitável na construção social em que vivemos). Ele cumpre estritamente o que tem de cumprir na escola. Sempre, sem exceção.

O terceiro desafio cultural foi realmente um desafio para mim.

Ao ler as primeiras linhas sobre o que seria a missão, não me interessei nem um pouco.

Teatro nunca foi meu programa favorito, prefiro cinema, mas desafio é desafio, temos que enfrentá-lo.

Desta vez, cumprir esta tarefa não foi nada fácil.

O local, as datas e os horários dos espetáculos não se encaixavam com os meus nem com os da minha mãe. Difícil!

Restou o Ballet Coppélia.

Compramos os bilhetes para a plateia e fomos retirá-los no Salão Assyrius, uma hora antes do início do espetáculo.

O lugar é lindo, me senti entrando em um palácio, um museu. Tudo novo, ou melhor, tudo antigo, mas com cara de saído do forno. Impecável!

Colunas altíssimas, escadaria com direito a tapete vermelho, três andares para os espectadores, fora o piso da plateia onde ficamos.

Tudo gigantesco!

Tudo novidade para mim!

O balé, em si, sinceramente achei sem graça.

o palco imenso, os cenários, os bailarinos e as músicas não conseguiram me conquistar, apesar de toda a beleza.

Para onde eu olhava, e eu não parava de olhar, só via adultos e meninas. Parecia que eu era o único garoto ali.

Foram as horas mais longas da minha vida.

Para falar a verdade, este desafio quase virou uma missão impossível. Taí, se fosse para assistir "Missão Impossivel" no cinema, eu iria adorar. Este programa, sim, tem a minha cara.

A outra missão a ser feita em casa (assistir a uma seleção de vídeos no

Youtube com músicas instrumentais) também gerou algumas experiências novas e interessantes, relatadas pelos alunos. Selecionei, em sua maioria, músicas temas de filmes famosos que, acreditava, todos conhecessem. A surpresa foi ver que, apesar de conhecidas de certa forma, muitos alunos demonstraram não dar atenção para elas nos filmes:

Assisti os videos e as músicas da missão 4, achei bem interessante. Pois nunca tinha parado para observar as sinfonias dos filmes. (...) Admito, quando vejo os filmes não presto muita atenção na sinfonia. (...) Assistindo os filmes, as pessoas ficam observando o desenrolar da ficção, e realmente ninguém para e escuta a música ou o instrumento que completa o filme. (AutorA52, grifo meu)

Para uns a experiência também foi de descobertas de algo que desconheciam. E as relações vão se criando e o conhecimento de mundo se 
formando por meio dessas conexões que surgem com as variadas práticas (grifarei um exemplo claro disso em AutorA42).

Eu amei, nunca tive a experiencia e tempo para ver videos de orquestras, na verdade eu tive tempo, mas eu nunca gostei de ver essas orquestras, achava chato demais, agora sei como é incrivel cada orquestra mais imprecionante que a outra (...). Eu nunca tinha percebido que precisava de tantos instrumentos para só uma musica, pensava que era preciso no maximo cinco instrumento (AutorA31, grifo meu)

O $5^{o}$ vídeo, a animação fantasia de Walt Disney, Vebrou-me o filme mudo de Charles Chaplin, o Garoto. Mostrou que a música é muito importante em uma produção de filmes ou desenhos. Raramente eu prestava atenção às músicas nos filmes que assistia, agora estou mais interessado e vou ficar mais atento. Nunca assisti uma orquestra, tentarei ver uma no próximo final de semana no Teatro Municipal do Rio de Janeiro. Não sabia que usava-se tantos instrumentos em uma só música (AutorA42, grifo meu)

A música instrumental nunca fez parte do meu mundo, ou melhor, eu achava que não fazia. Só agora percebi quantas delas já passaram por mim e eu nem havia me dado conta. (...)

Depois dessa missão, a música instrumental ganhou o seu mais novo adepto. (AutorB34, grifo теu)

(...) nunca tive o "ouvido atento" para saber que são necessarias dezenas de pessoas para fazer esses temas.

Para mim tudo era feito no computador, tudo fácil, porém na verdade é muito difícil. (AutorA21, grifo meu)

Além disso, a percepção do trabalho, das habilidades e da beleza, por si só, já valem a oportunidade de aprendizagem. E isso, a meu ver, esbarra na grande diferença entre a perspectiva de ensino, vista como "instrução", da perspectiva da aprendizagem, entendida como "formação". (Vasconcelos, 2006; Macedo - em vídeo $^{45}$ )

O interessante foi os músicos com os instrumentos na boca, tinha um enorme fôlego, e com a junção de vários instrumentos podemos criar muitas músicas agradáveis. (AutorA10, grifo meu)

Achei os vídeos bem legais, pelo fato de alguns maestros tocarem instrumentos e reger a orquestra paralelamente, como na Orquestra do tema Missão impossível. Também me chamou atenção a maneira como o trompete e o piano se destacaram individualmente. Apesar de já conhecer todos os temas dos filmes, nunca tinha assitido a esses vídeos com as orquestras. Bateria, trompetes, violinos, trombones, flautas, tubas, entre outros instrumentos me deixaram surpreso com tanta riqueza instrumental. Sem falar de todo o Fôlego dos músicos e a agilidade com as partituras. É preciso muita dedicação e muito ensaio para tudo ocorrer perfeito. (AutorA38, grifos meus)

\footnotetext{
${ }^{45}\langle$ https://www.youtube.com/watch?v=TgTI5gSI07c >
} 
O aluno AutorB53, sempre muito crítico e arredio às minhas propostas, parece querer me provocar e me enfrentar de alguma forma. Embora capaz, sai escrevendo direto, sem pausa, sem pontuação praticamente. Ele nunca está satisfeito com nada, constantemente tem algo para reclamar, mas, apesar de ser capaz, não faz isso com cuidado, com uma boa escrita, por exemplo. Ele parece estar cumprindo uma atividade entediante por pura obrigação:

Eu não gostei muito (nem um pouco) de ter que ouvir as músicas "temas" desses filmes porque ja imaginava que usavam vários desses instrumento já que é um orquestra e a meu ver temos que usar varios instrumentos já que por exemplo o violão toca mais alto que a flauta e nós queremos um som igual temos que equilibrar o som usando mais de uma flauta e outras coisas do tipo é e por isso que numa orquestra vemos vários instrumentos repetidos, e ja conhecia as músicas de todos esses menos o da Walt Disney e a música porem não tinha vontade de saber.

obs: Alguns desses links eu não achei como o do 007 e logo tive que pesquisar no youtube na "natura". (AutorB54, grifo meu)

Esse aluno - sempre duro e agressivo com tudo que lhe exige suavidade e sentimento -, parece-me, foi muito bem "adestrado" no paradigma de uma escola tradicional, na qual a razão, o intelecto devem sempre ser priorizados dando valor exclusivamente ao mérito intelectual, em detrimento da emoção. Vasconcelos (2006) mostra que se construiu uma crença de que a emoção não levaria ao conhecimento e poderia provocar atitudes irracionais.

A última missão pedia que o aluno escolhesse um programa cultural para fazer. Os relatos mostraram que os que realizaram essa tarefa com a família foram a estes locais:

- Museu Aeroespacial: exposição de aviões e a história de Santos Dumont

- Centro Cultural Banco do Brasil: instalações no espaço central e exposição das moedas (acervo)

- Centro Cultural dos Correios

- Museu de Arte do Rio: exposição sobre a Amazônia

- Caixa Cultural: Exposição Fotográfica Histórias Naturais (Fotógrafo Marcelo Tinoco)

- Museu Nacional do Parque da Quinta da Boa Vista: acervo

- Centro Cultural João Nogueira - exposição sobre o sambista (acervo) 


\subsubsection{Atividades complementares}

Ao longo dos dois bimestres de mudança de paradigma, em que apliquei todo o tempo uma estratégia lúdica e dinâmica de produção e construção da aprendizagem, houve alguns rápidos momentos em que precisei fazer uso de uma didática mais tradicional com aula expositiva (itens 14, 27 e 35, do quadro abaixo) ou precisei realizar alguma atividade para a organização de elementos desse mesmo processo e também de minha pesquisa (itens $1,6,19,22,36$ e 38, do quadro abaixo). São eles:

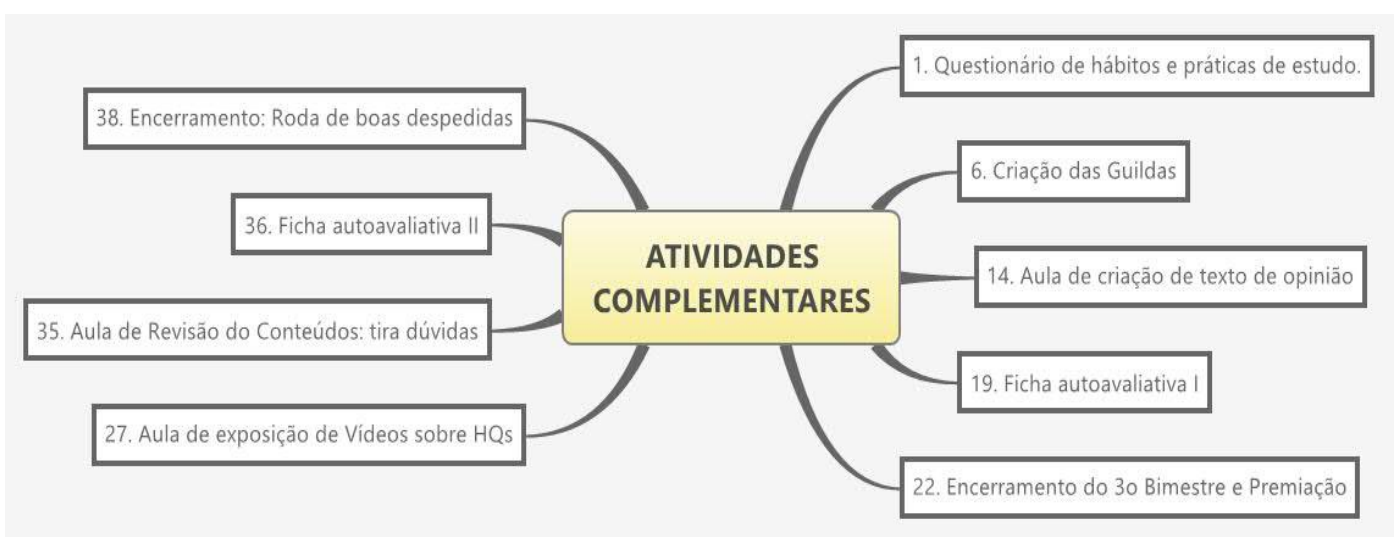

Quadro 13:Panorama geral das atividades complementares, com quadro explicativo.

Algumas dessas atividades acabaram sendo descritas e comentadas na ordem cronológica em que apresentei as realizações do semestre. O questionário de hábitos de estudo e a criação das guildas foram apresentados no capítulo 3; a aula de criação de texto de opinião, a aula com vídeos sobre HQse o encerramento e boas despedidas aparecem no capítulo 4 .

- Sobre a premiação

Demorei alguns dias para fechar a premiação porque precisava ler todas as autoavaliações $^{46}$ e a votação que eles fizeram para as apresentações do teatro de fantoches. Além disso, precisava somar todos os pontos dos membros mais os pontos das guildas. Eles estavam esperando ansiosos pelo resultado porque, como

${ }^{46}$ Criei uma ficha (Anexo 5) para que os alunos votassem na peça que eles mais tinham gostado. Aproveitei o espaço para fazer uma autoavaliação da realização da atividade por eles. Essa autovaliação, embora não esteja indicada como um item das atividades complementares, aparece explicada mais adiante nas páginas 131 e 132. 
pediram e eu acatei, haveria um prêmio concreto. E no caso da turma B, que teve um problema específico com relação ao uso de pontos e ranking ${ }^{47}$, a disputa final ficou acirrada entre a guilda que liderou a turma ao longo de todo o bimestre e a que saiu da situação de humilhação para estar páreo a páreo concorrendo pelo primeiro lugar.

Em um tempo em cada turma, expliquei todos os critérios de somas dos pontos individuais, a "regra de três" que criei para que todas as guildas tivessem o mesmo peso em pontos já que metade tinha cinco membros e a outra metade quatro cada uma; expliquei também como foi feita a pontuação do teatro de fantoches a partir da votação deles mesmos somada à minha, e a soma de tudo isso com os pontos ganhos nas guildas.

Interessante foi perceber - e poder levantar essa questão para uma discussão com os alunos - que as guildas vencedoras (uma em cada turma) tinham em comum algo que eu vinha apontando para todos desde o início: cada membrohavia se comprometido com o processo e realizado as suas atividades individuais. Esses alunos não deixaram para os colegas o "peso" das atividades. Eles trabalharam em conjunto, sempre em um processo colaborativo, e individualmente, tendo assim responsabilidade por sua aprendizagem e responsabilidade para com a sua guilda. Os alunos repararam claramente que foi a realização das tarefas individuais que gerou o maior (ou o menor) número de pontos para os grupos. Isso significa que a participação efetiva de cada um fez a diferença no resultado final.

- Sobre a revisão de conteúdos

A aula de revisão de conteúdos (item 35, do quadro acima) é uma prática indicada pelo colégio para que seja assegurado ao aluno o direito de sanar suas dúvidas e ser direcionado didaticamente para a avaliação que irá fazer (saber o conteúdo que será cobrado, o que precisa realmente estudar etc.). Foi uma aula com a estrutura tradicional de leitura de algumas partes mais importantes do livro paradidático e algumas poucas perguntas foram feitas por eles a respeito de conotação, denotação, substantivo e adjetivo.

- Sobre as autoavaliações

As duas autoavaliações realizadas no final de cada bimestre expuseram ao aluno, de forma bastante objetiva, passos das atividades que ele, como estudante,

\footnotetext{
${ }^{47}$ Essaquestão será desenvolvida a partir da página 201.
} 
tinha de cumprir. Nas perguntas, evidenciei algumas questões que, numa avaliação mais geral do sujeito durante a realização das atividades, eu não levei em conta. No entanto, considerei válido destacar, para que o próprio aluno tivesse como perceber o que vinha (ou não) fazendo e como vinha (ou não) se colocando no seu processo de aprendizagem. Por isso, perguntas sobre cumprimento dos prazos, da entrega de determinado trabalho com boa apresentação, da realização de reescrituras, entre outras fizeram parte de ambas as autoavaliações.Nas perguntas abertas, os alunos expuseram seus sentimentos e emoções sobre o bimestre.

Houve ainda uma autoavaliação pontual realizada logo após a apresentação dos teatros de fantoches. Não computei isso em nenhum dos quadros, como atividade, porque o objetivo inicial era só a votação da melhor peça apresentada pelos alunos e foi criada depois, isto é, não foi previamente planejada. No entanto, usei a oportunidade para observar como cada aluno enxergava a sua atuação na realização do trabalho e como ele enxergava a atuação do colega.

\subsubsection{As relações na aprendizagem: uma percepção do todo (parte 2)}

Retomando a visão geral do programa de LP para o $6^{\circ}$ ano no SCMB, segundo o Plano de Sequências Didáticas (PSD), apresento abaixo, a fim de seguir o que foi feito ao final do capítulo anterior, o quadro referente ao quarto bimestre letivo. Tal quadro mantém o mesmo padrão já apresentado. Cada uma das práticas (Escuta e Leitura; Produção de Textos; Análise Linguística) é apresentada com uma cor diferente e essas cores são usadas em símbolos (triângulo roxo, estrela laranja e seta verde) para clarificar, além das linhas, com que práticas determinado conteúdo foi desenvolvido.

Com a imagem, podemos perceber não só as inter-relações alcançadas com essa estratégia como também o cumprimento de todo o conteúdo proposto pela instituição para o período em que realizei a pesquisa. Mais uma vez, e agora de forma até mais acentuada, pude verificar e ratificar que as inter-relações que se construíam entre os conteúdos (Objetos de Conhecimento) de cada prática nas missões propostas aumentaram com um maior desenvolvimento de atividades com produções textuais variadas. 


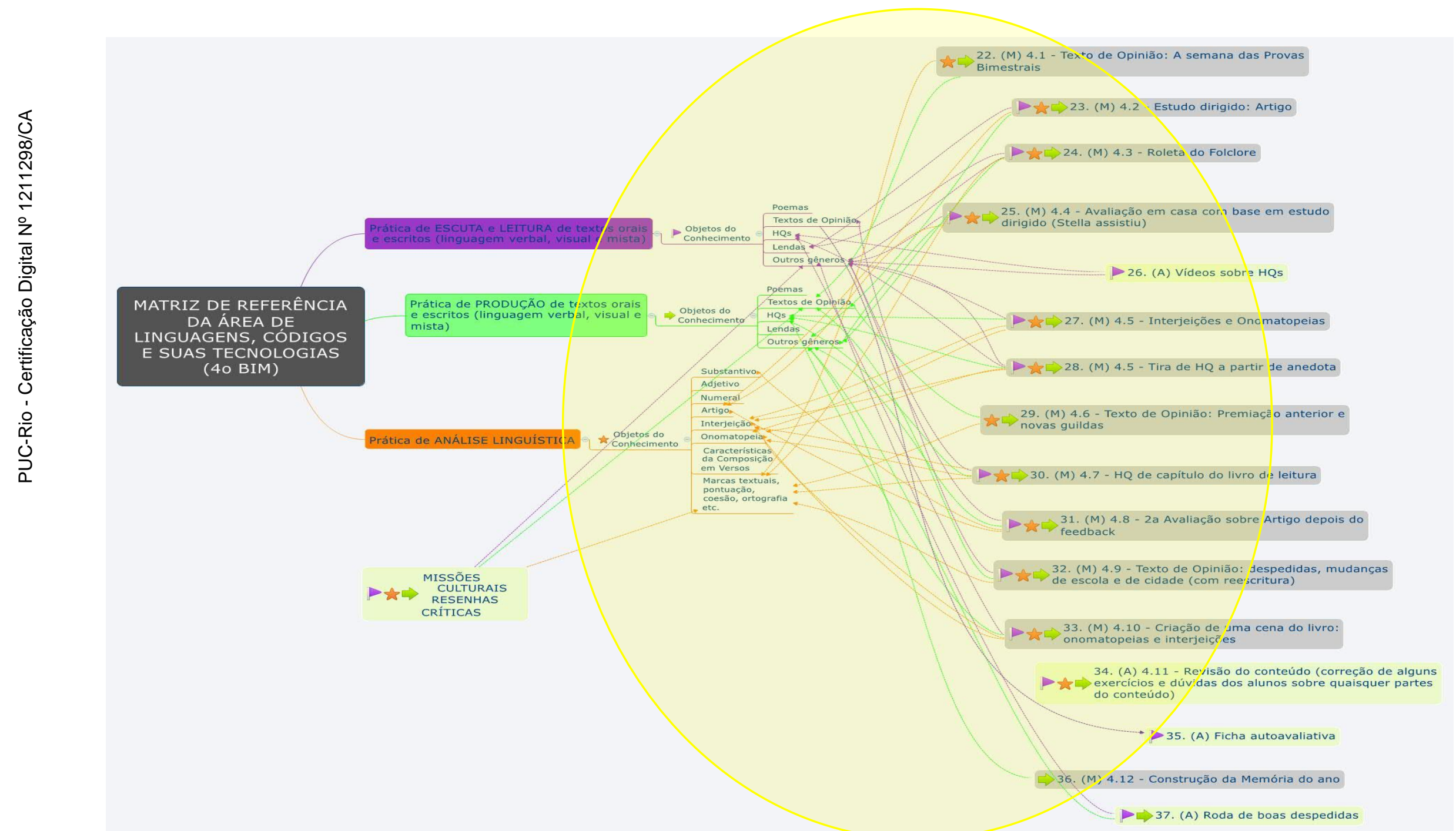

Quadro 14:Inter-relações dos conteúdos de LP por meio de variadas práticas. 
Embora a apresentação dos dados aqui realizada não permita nem de longe a reprodução exata do que foi feito, essa descrição se faz relevante para que se entenda claramente a realização da pesquisa-ação e a clara noção do processo reflexivo que se atingiu a fim de se caracterizar também como um autoestudo. 


\section{A culminância da experiência: discussão dos dados (parte 1)}

A construção de uma autorreflexão sobre as práticas docentes proporciona opostamente a sensação, ora de dever cumprido, ora de aflição. O primeiro diz respeito às conquistas gerais; o segundo marca o não cumprimento, em cem por cento dos casos, do objetivo maior do meu trabalho: a aprendizagem do aluno. Essas percepções dicotômicas estão apresentadas aqui neste capítulo.

\subsection{O que a estratégiaproporcionou de concreto na formação desses alunos?}

A produção textual dos alunos, desde o início da estratégia, tinha dois aspectos diferentes. Um dizia respeito ao nosso (re)conhecimento professor-aluno, bastante singular e personalizado; o outro, como eu estava inserida em um contexto com regras bem rígidas de cumprimento de conteúdos, buscava o aspecto que a escola deseja e cobra: a aprendizagem das questões específicas da LP para uma boa comunicação escrita.

Em relação ao primeiro aspecto, minha avaliação qualitativa da estratégia é de total sucesso, visto que os alunos se sentiram em um ambiente seguro, em situação confortável e de confiança para se expressar e opinar sobre todos os temas que levantamos. Seus escritos - com posicionamentos ora positivos, ora negativos em relação a meu trabalho -, suas percepções implacáveis sobre os processos de avaliação escolar e suas denúncias e críticas, nada benevolentes, sobre a atuação de seus colegas nos grupos, são exemplos dessa facilidade criada em nossa comunicação. Isso - a meu ver - permitiu um crescente desenvolvimento da fluência textual. Não foram poucos textos. Houve diversas oportunidades para o exercício da expressão (nas modalidades oral e escrita), para exercer a liberdade e o direito de dizer o que se pensa.

O segundo aspecto, já voltado para a aprendizagem formal da LP, ia sendo conduzido por mim também de modo personalizado. Com o auxílio de um código 
de correção ${ }^{48}$ que já havíamos criado no primeiro semestre, apontava para eles os probleminhas que surgiam em seus textos, sem lhes dar a resposta nem fazer a correção. Dessa forma, eles tinham a oportunidade de procurar o erro para corrigilo, numa relação de significação do erro, nova tentativa, possível novo erro, nova reflexão, nova tentativa, até acertar. Com os códigos sendo indicados sem caneta vermelha e sem que seus textos fossem "rabiscados" numa correção "hemorrágica" tão conhecida dos bancos escolares, o processo se tornava mais tranquilo, menos agressivo e muito mais afetivo. Isso significa que os dois aspectos se complementavam, promovendo a confiança necessária para a aprendizagem.

Diante desses dois polos entrelaçados, pude verificar a evolução (ou não) dos autores desta pesquisa no que diz respeito à expressão da opinião e à comunicação (prioritariamente) escrita. De forma, em parte, qualitativa, portanto subjetiva (avaliação que, eu, professora, faço dos alunos com quem trabalhei no ano letivo de 2014, observando, principalmente o período da pesquisa), em parte objetiva e pontual, tendo como base a comparação dos textos de cada aluno, utilizei a classificação criada por mim, para clarificar essa evolução na aprendizagem $^{49}$, por vezes formal (aqui adentro no campo mais intelectivo da aprendizagem da LP), por vezes mais afetivo ou emocional, no que diz respeito à capacidade de expressar-se.

$\mathrm{Na}$ verdade, os exemplos que apresento têm os dois aspectos bastante evidentes. Basta sermos observadores atentos de alguns pontos como a disposição do texto na folha (apresentação do espaço, letra, paragrafação). Esse é um bom exemplo de um aspecto formal da aprendizagem que pode demonstrar um desenvolvimento de segurança, de autoestima, de noção do espaço pelo aluno. Outro ponto é a seleção vocabular que evolui de termos mais orais e coloquiais, com ideias que giram em torno de si mesmas sem progressão textual, para expressões e argumentos que são ampliados, desenvolvidos.

Considero muito importante lembrar sempre que o processo de escrita e reescrita constante surtiu efeito não pela quantidade em si, mas, acima de tudo, pela qualidade da interação (embora uma prática rotineira significativa auxilie em um aperfeiçoamento). Por tudo isso, houve diferenças claras no amadurecimento e

\footnotetext{
${ }^{48} \mathrm{O}$ código de correção e a grade que utilizava para a pontuação estão no anexo 6 .

${ }^{49}$ Tal classificação já foi apresentada no capítulo 3 .
} 
desenvolvimento de cada um. Cada atividade única, aparentemente geral, se fazia particular e era intransferível. Portanto, cada produção se tornava também única e especial seguindo a noção de que "uma escola para todos supõe a disponibilidade para a prática de uma pedagogia diferenciada e uma avaliação formativa", como afirma Macedo (2007, p. 44).

A evolução qualitativa do aluno foi avaliada, então, segundo o quadro já apresentado no capítulo 3, mas que reproduzo aqui novamente para o acompanhamento das informações que seguem abaixo:

\begin{tabular}{|c|c|}
\hline & $\begin{array}{c}\text { Estava aquém do } 6^{\circ} \text { ano e não desenvolveu a capacidade de } \\
\text { expressar sua opinião sobre o mundo que o cerca. }\end{array}$ \\
\hline & $\begin{array}{c}\text { Já estava aquém do } 6^{\circ} \text { ano e ainda teve uma queda em sua } \\
\text { aprendizagem. }\end{array}$ \\
\hline & $\begin{array}{c}\text { Já estava no nível adequado ou acima, mas não apresentou um } \\
\text { crescimento significativo em algum aspecto. }\end{array}$ \\
\hline & $\begin{array}{c}\text { Já estava no nível adequado ou acima e melhorou em algum } \\
\text { aspecto. }\end{array}$ \\
\hline & Estava aquém do $6^{\circ}$ ano e apresentou uma boa aprendizagem. \\
\hline & $\begin{array}{c}\text { Estava no nível adequado ou acima, mas apresentou uma } \\
\text { queda em sua aprendizagem. }\end{array}$ \\
\hline & $\begin{array}{c}\text { Estava aquém do } 6^{\circ} \text { ano, apresentou uma melhora, mas não } \\
\text { atingiu o mínimo esperado. }\end{array}$ \\
\hline
\end{tabular}

Quadro 15: Código para representar a evolução qualitativa de cada aluno.

Percebi, com relação à aprendizagem da escrita, que a maioria dos alunos que dialogava comigo - ouvindo meu feedback oral, lendo meus bilhetes e analisando os problemas particulares apontados no caderno - e que, depois, fazia as reescrituras apresentou uma melhora em sua capacidade de comunicação por meio da escrita. Dos quarenta cadernos que pude avaliar pelo quantitativo de redações em condições de comparar a evolução, consegui detectar que trinta e seisautores apresentaram algum nível de melhora na produção escrita, enquanto um que já era muito bom, permaneceu mais ou menos no mesmo nível, porque era difícil esperar uma evolução tão aparente;três que estavam aquém do mínimo esperado para um aluno de $6^{\circ}$ ano permaneceram sem um avanço qualitativo. $\mathrm{O}$ quadro apresenta o quantitativo de cada um especificamente: 


\begin{tabular}{|c|c|c|c|}
\hline $\mathbf{N}^{\mathbf{0}}$. Autores & Evolução & $\mathbf{N}^{\mathbf{0}}$. Autores & Evolução \\
\hline 13 & $\longrightarrow$ & 13 & \\
\hline 01 & $\longrightarrow$ & 10 & \\
\hline 03 & $\longrightarrow$ & 0 & \\
\hline
\end{tabular}

Quadro 16:Quantitativo de alunos em cada categoria de evolução.

Eis alguns exemplos:

Evolução

(Estava aquém do $6^{\circ}$ ano e apresentou uma boa aprendizagem.)

AutorB38 é um exemplo de um bom desenvolvimento na capacidade de expressão escrita. Ele demonstrou, desde o início, ter opinião própria, mas apresentava uma letra irregular e uma grafia com diversos problemas, além do desconhecimento de regras básicas de pontuação, organização de períodos, parágrafos. A comparação entre três textos seus de momentos distintos ao longo da estratégia (ver as três figuras que seguem abaixo) clarifica isso. $\mathrm{O}$ último texto mostra um grande avanço em sua aprendizagem no que diz respeito às questões linguísticas e de estruturação do texto, embora ainda haja pequenos deslizes. Essa estrutuação de texto mais equilibrada corrobora a questão que mencionei sobre a segurança e a confiança. Esse aluno não acreditava que era capaz de escrever, de se expressar e o fazia com preguiça e falta de interesse, confirmando a informação dada em seu questionário quando informou não gostar de escrever. O diálogo constante, a atenção personalizada e as diversas oportunidades levaram-no a desenvolver uma empatia comigo e um interesse em mostrar que era capaz de se superar.

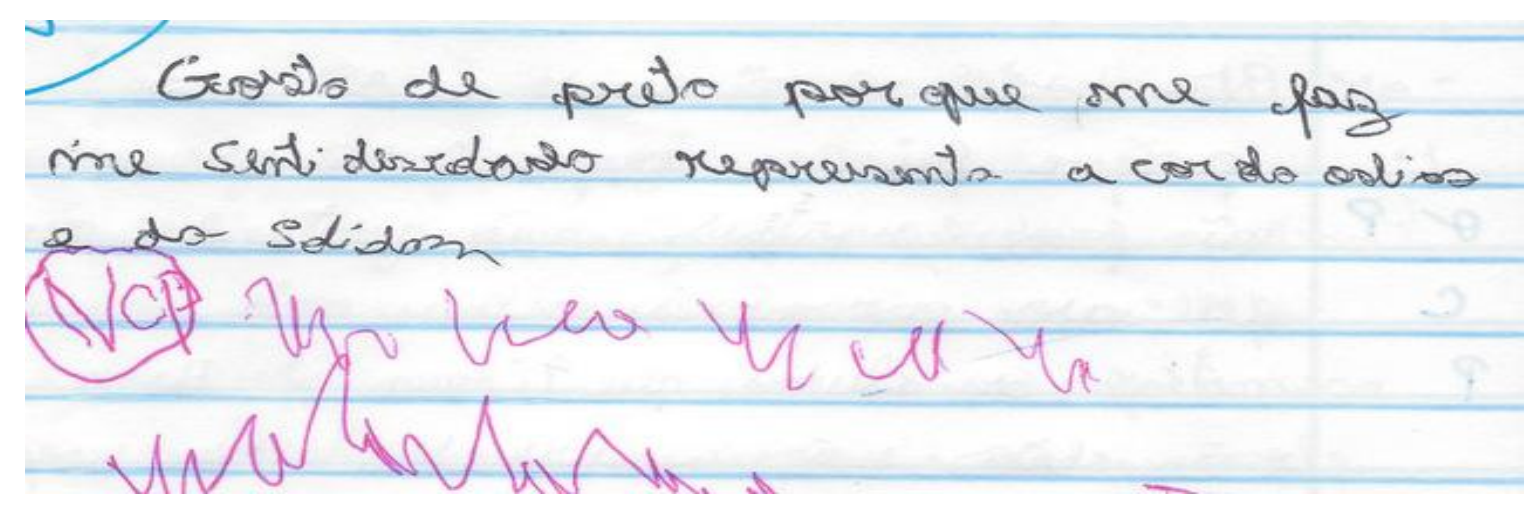

Figura 23:Texto 1 de 3 de AutorB38. 

Wha "panon a manche"s näs par on mais! Obsene fus näs lá um parto on uns vingula refues. Vomen reloweFilipe Cartille autor do Livoro lawe-

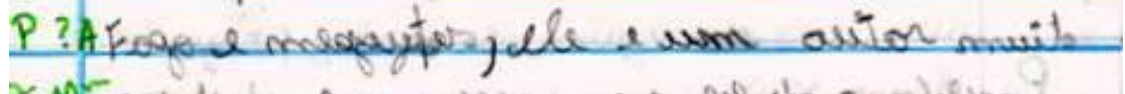

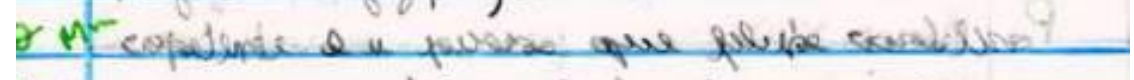

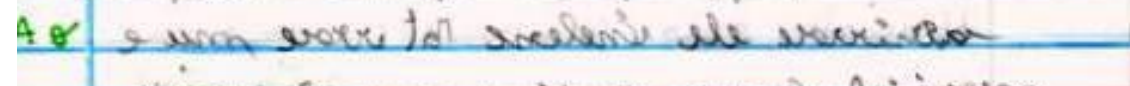

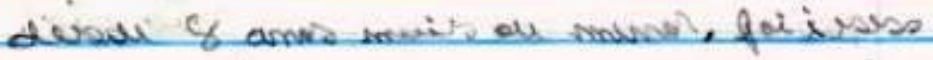

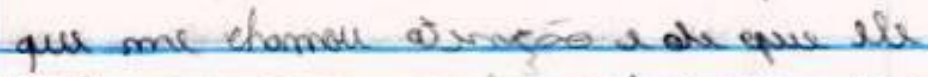

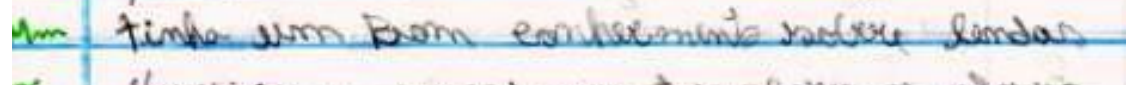

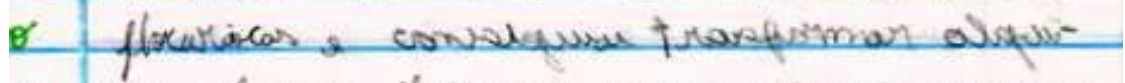

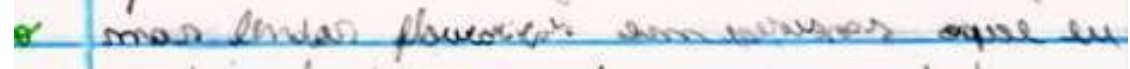

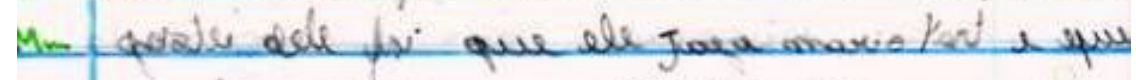

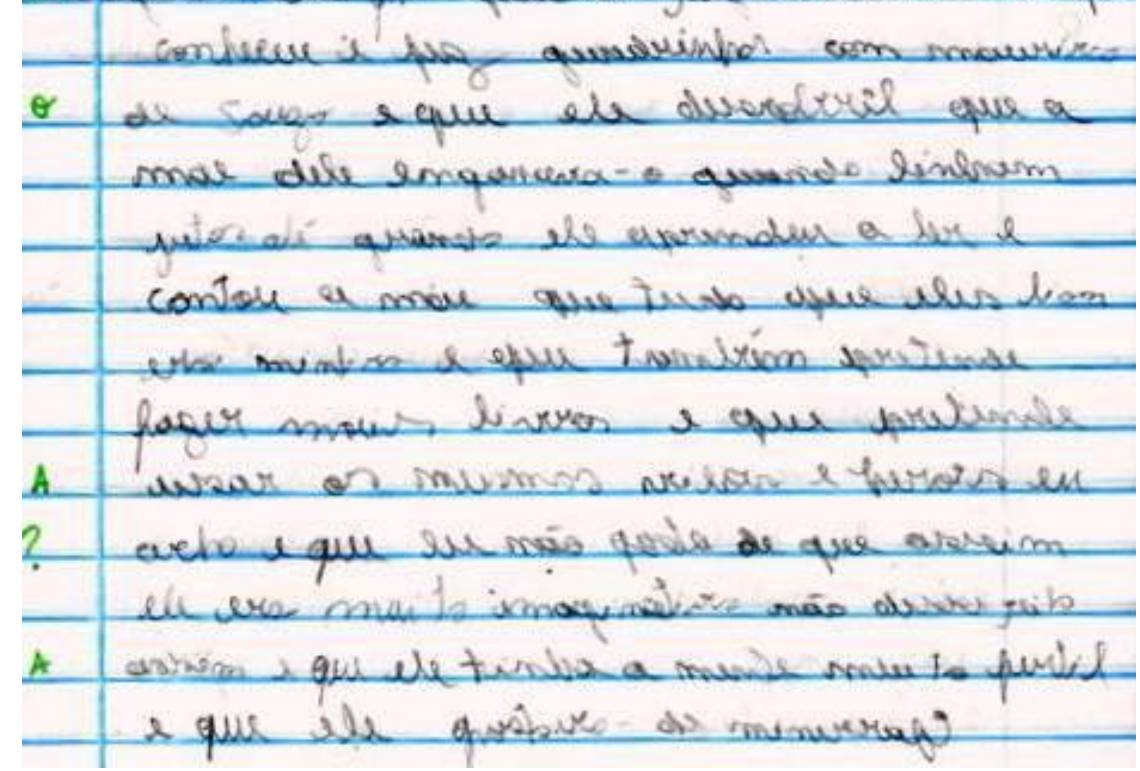
Figura 24:Texto 2 de 3 de AutorB38. 
Em Jamiiro duste ano ingreveri nuste EataBelerimento de Envino por motinco de tranuffertioncia de meu pai, portanto ustour no grupo dagueles ques irão permanuur no colígio. Ainda sstudarei por mainm algunss anos mo Rio de Jamuino, pairs mums paits smä tem pretennáa de mudar de eidade.

$\checkmark$ Fato de ter ave mudar mão e uma cidia que me agrada muito, paiss como salum mós sempro diexamos armigos que congristasmon para trás. Porím entendo que taiss mudangars pagam parte do trableolhe domurpai.

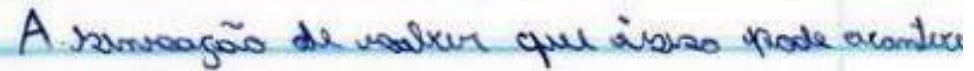

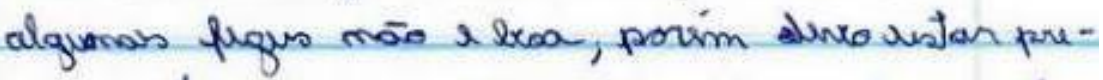

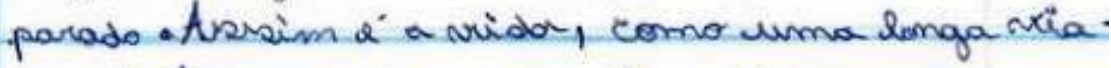
gem de trem, onde sempre Ranureas perssoas que sultirão á lcords e que descunāo em algusm momento, deicando saudaden. A Fimal tudo que impenta usäs leorrs momentos de as beows incepriénciars que fram compontilhadar. É o que

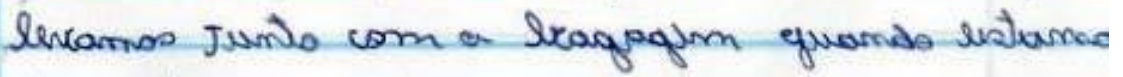
de partidare

Figura 25:Texto 3 de 3 de AutorB38.

AutorB20 é outro exemplo desse crescimento na capacidade de comunicação, principalmente por meio da escrita.Sua construção escrita inicial (mais acentuada ainda no primeiro semestre letivo) era de base bastante oral, coloquial, com um vocabulário bem escasso, o que gerava uma comunicação rasa, sem muita chance de uma conversa evoluir porque não possuía vocabulário para isso. Mantinha-se sempre no "legal", usava até gírias mais antigas como "maneiro" para expressar sua opinião, sem ir muito adiante.Essa aluna, porém, conseguiu, ao longo do segundo semestre, apresentar um bom desenvolvimento em sua produção oral e escrita. Credito essaevolução principalmente porque valorizei seu gosto por uma literatura de ficção científica e de terror, oferecendo- 
lhe livros para que lesse toda semana e trocasse algumas ideias comigo. Isso a aproximou muito de mim e facilitou a interação.É possível encontrar ainda em seu último texto marcas da oralidade e deslizes no uso correto da Língua Portuguesa, o que poderia mantê-la na categoria de evolução sem atingir o mínimo para o ano em questão. No entanto, seu crescimento como aluna, com atitude de estudante, com uma escrita mais calma, mais organizada, mais pensada, mais centrada, não poderia ser ignorada nessa minha avaliação. Infelizmenteficou reprovada em outras disciplinas.

$\checkmark$ A chei logal a Aturridade $\checkmark$ pdo cor muits legal, Mm $\theta$ as pesseas firweram chan $x$ OP oce exprecar seus sentumentos * mais ná gostei da

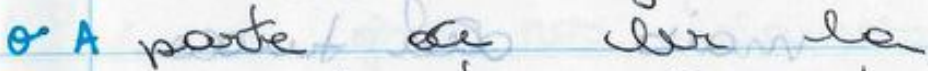
- na frente por tenho um pouco de vergorha.

Figura 26:Texto 1 de 3 de AutorB20. 
Q. munha opiniäo ofa palheptra com

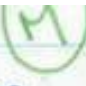

Mim felepe castilho.

Esoa entrenista corrue no.l cmrino.

A batallios onde fica o avalitorio.

MimP Ami conhecer helipe castillo, ele

A.P é um ginlo, nos falamos setere

C lenclas u como rai ser as

P autros livros dele wou querer

$\sigma$ ler todos. Ele í norro mais usorerre conno ser tivesse uns

A $R 30$ andos on 40 peraque de e

OpRmuito esperiente, ele vai ser

car muito bum na carreivo.

a escritor.

Eu sei algumas cobsas sadre

ele type ule tem 28 amos, nāo.

u' cavadio, term uma vai-jade? quinta de estrmaçäo, en

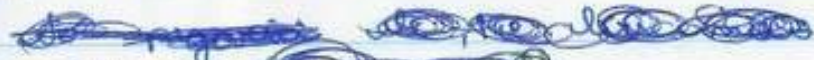

as

En adimive (ele) sé $\theta$

trabralho dell.

Figura 27:Texto 2 de 3 de AutorB20 (parte 1). 


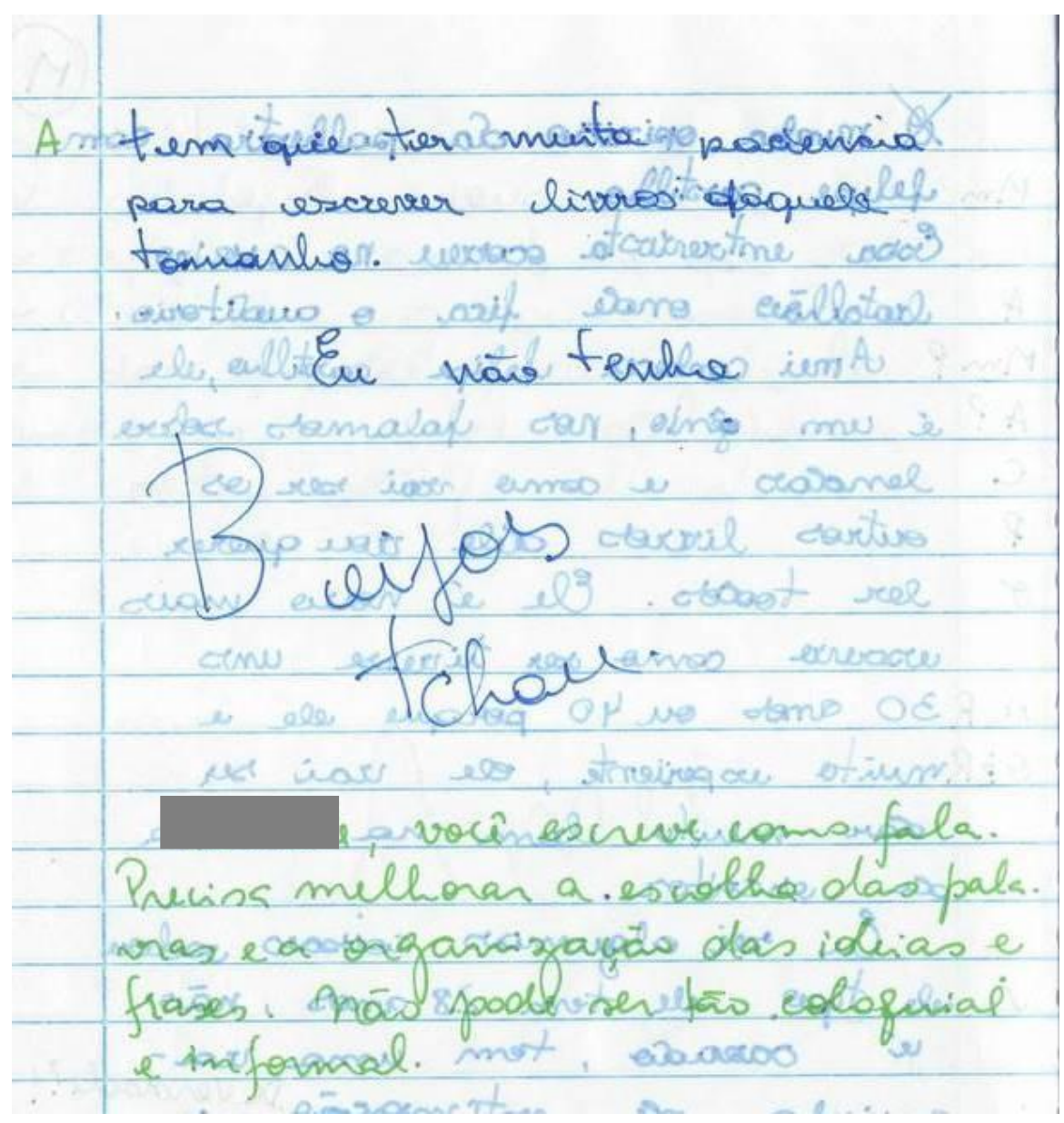

Figura 28:Texto 2 de 3 de AutorB20 (parte 2). 


\section{Pedaçáa}

$\checkmark$ ano paraser tao rápido um tempo atrós ustarea no primuivo laimestre e ue mal conhecia as persecas da roala de aula. Henha premaura amuga Loi a pais ela i do meer onibus e fai mais facil conheítra. Ainda nấ sie ve rou ficar no colígio militar, pous talrez en repita de ano e se usso aconteer ele posso saur de alégio. Nös quero sair pais goste muite do adegio, na minha veala vêu sair se a a í ve wou senter soudades da l pois ela me afuda quando preaso * ela í muits legal comigo, já a $P$ i legal as veges, mais brunca muito eom a minha cara porque un nasii no Acre, nöo sei porque tanta foricadeira comigo, per isso now vou sentir tanta falta dele.

Figura 29:Texto 3 de 3 de AutorB20 (parte 1). 


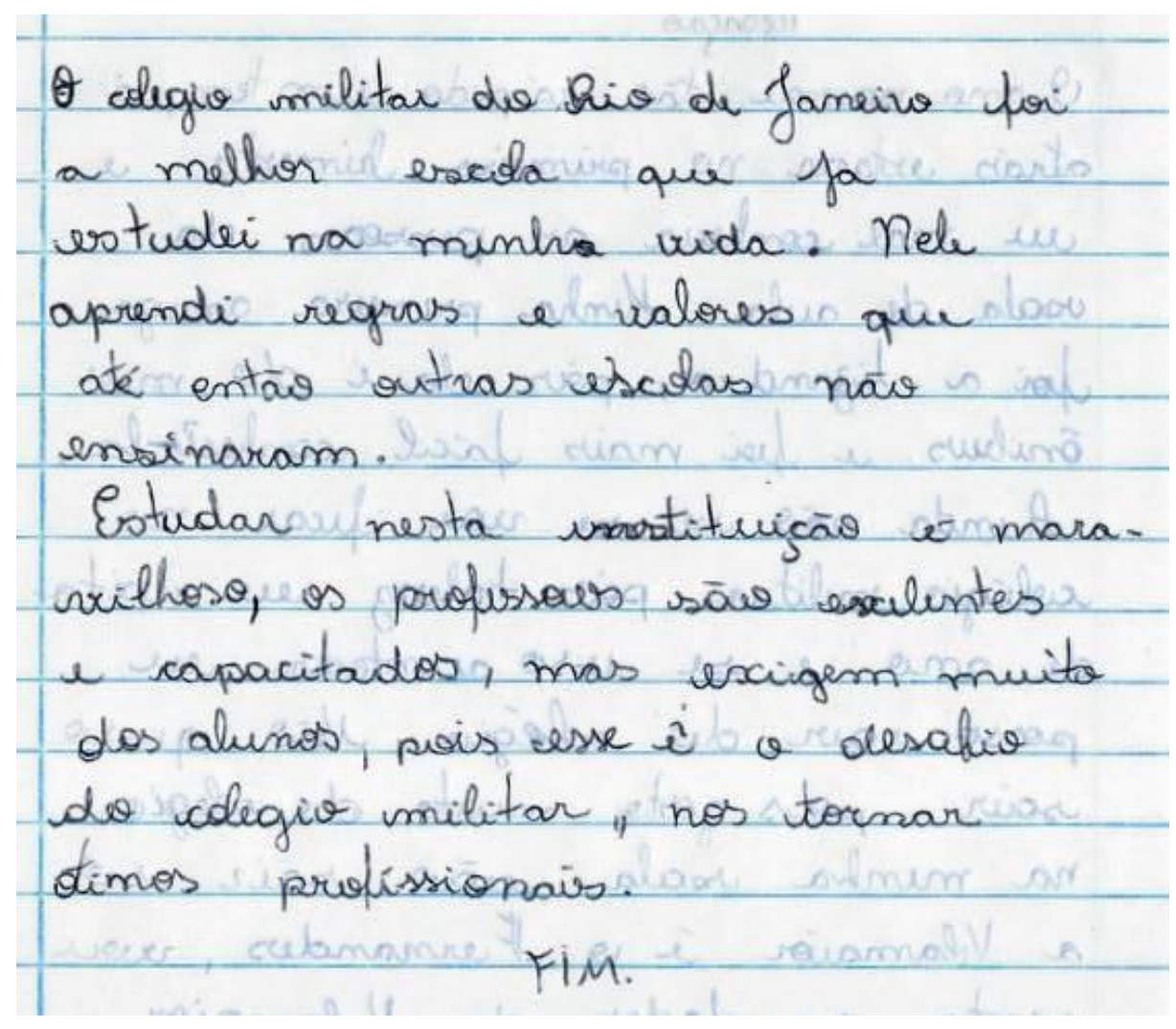

Figura 30:Texto 3 de 3 de AutorB20 (parte 2).

Evolução

(Estava aquém do $6^{\circ}$ ano, apresentou uma melhora, mas não atingiu o mínimo esperado.)

AutorA10 é um caso de aluno que apresentava um nível um pouco aquém para o ano escolar, principalmente na oralidade, inclusive com algum problema na dicção. Embora tenha melhorado em alguns aspectos, não atingiu o que se espera para a faixa etária. Ele tinha alguma dificuldade para expressar (desenrolar, desenvolver) suas ideias numa produção escrita, aumentados pelos problemas na estrutura mais formal da Língua Portuguesa. Ao longo da estratégia começou a ser mais atento com a sua produção textual, o que por si só já é uma boa aprendizagem, mas não chegou ao fim do semestre com uma maior desenvoltura na capacidade expressiva da opinião (oral também. Tinha muita dificuldade.). A própria pouca legibilidade do texto, que não é por uma questão de digitalização da imagem, já demonstra a dificuldade que esse aluno tem em se comunicar pela escrita. 
150

1) que fezenon, e) que ricks mais

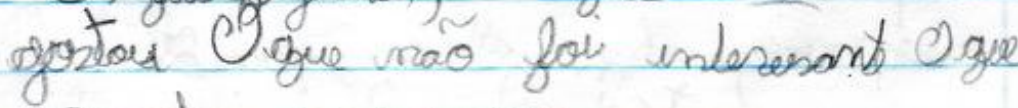
aprenter na semona-

Fizemos apendemos, expowersar ina noviza upenia volre ríáas Coras e bear poemas revivals \& monmais.

mavs gopter gastei de taprender a Trabiolhar em guespo, e-a faner poemar e xom lewar noma vdévo sovere a con pregereda.

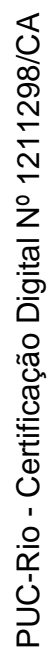
Thä for enteresanto noda para mum tudo for intanersonte Par navo for ocuula rellha aila de conregi as moto de awla.

Figura 31:Texto 1 de 3 de AutorA10. 


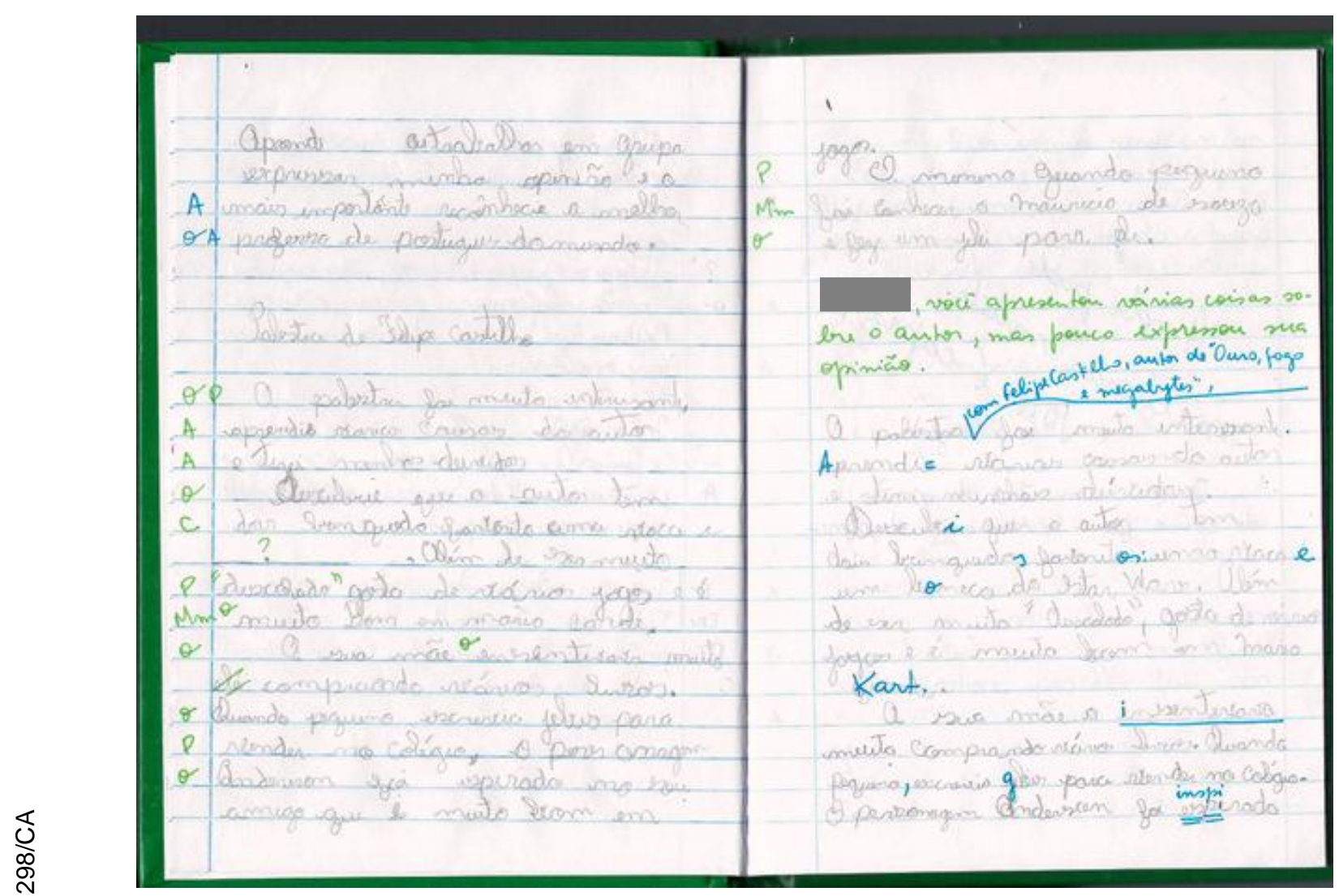

Figura 32:Texto 2 de 3 de AutorA10.

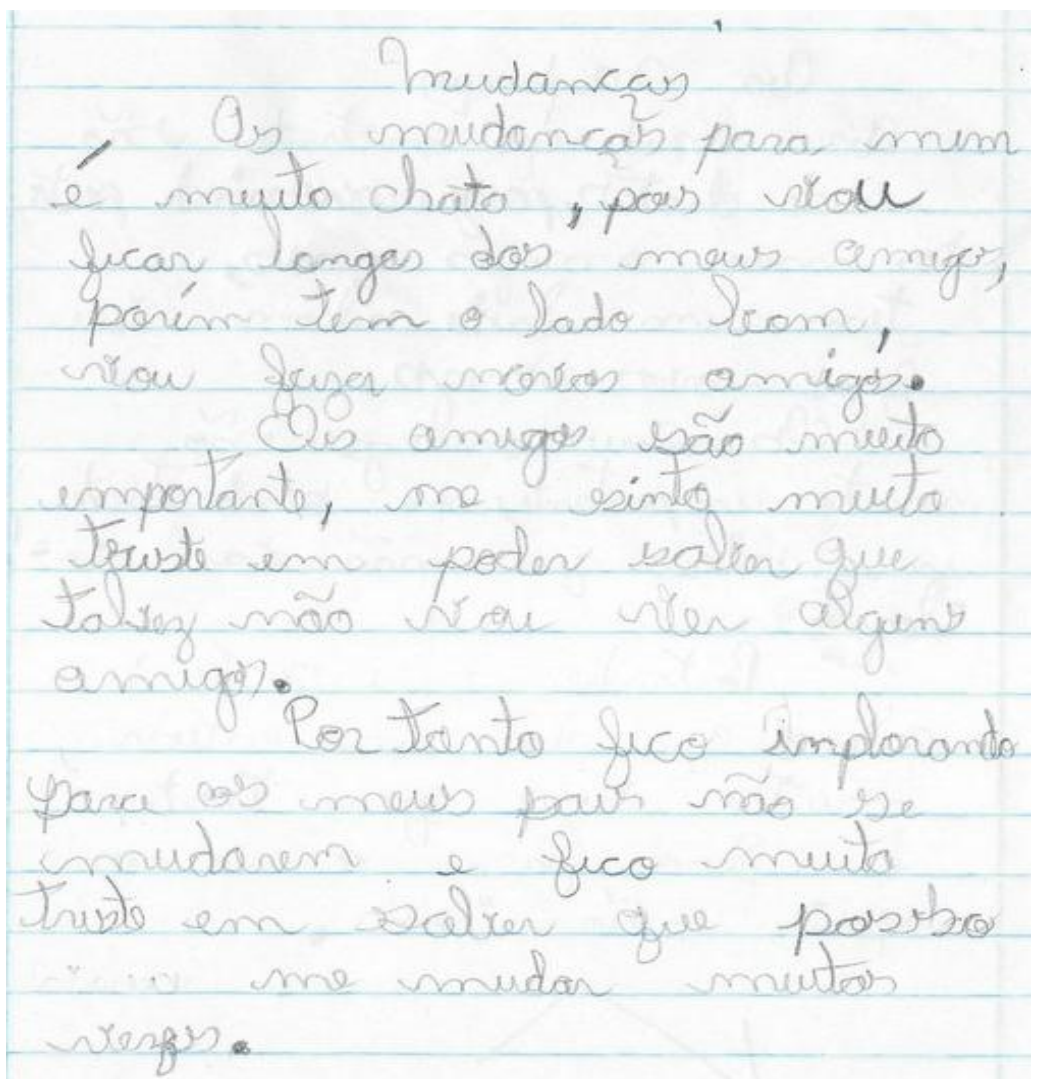

Figura 33:Texto 3 de 3 de AutorA10. 


\section{Evolução}

(Estava aquém do $6^{\circ}$ ano e não desenvolveu a capacidade de expressar sua opinião sobre o mundo que o cerca.)

AutorB14 disse, no questionário de perfil do aluno aplicado no início da pesquisa, que adorava escrever. No entanto, era um aluno que não se envolvia muito com as atividades, talvez por um excesso de timidez. Ele falava tão baixo e tão para dentro, que o indiquei para avaliação na Seção Psicopedagógica da instituição, para ver se seria o caso de um acompanhamento por fonoaudiólogo. Tinha muita dificuldade para entender o que se pedia para fazer e, normalmente por isso, precisava realizar a tarefa mais de uma vez. Apesar de a estratégia com as propostas de trabalhos em grupo ter gerado mudanças positivas em sua conduta e na sua integração com os colegas - ponto bastante positivo da estratégia -, não conseguiu, até o final do ano, sanar várias dificuldades, dentre elas problemas que tentei trabalhar com ele ao longo do semestre na construção de seu texto, principalmente no que diz respeito à clareza nas informações. Mesmo tendo opinião própria (isso aparece em seu texto), não houve uma evolução na sua capacidade de comunicação por meio da escrita, mas também - e talvez principalmente - se manteve com grande dificuldade em nossa interação oral. Eu tinha sempre muita dificuldade para entender o que ele dizia e ele não conseguia se expressar de forma inteligível. 


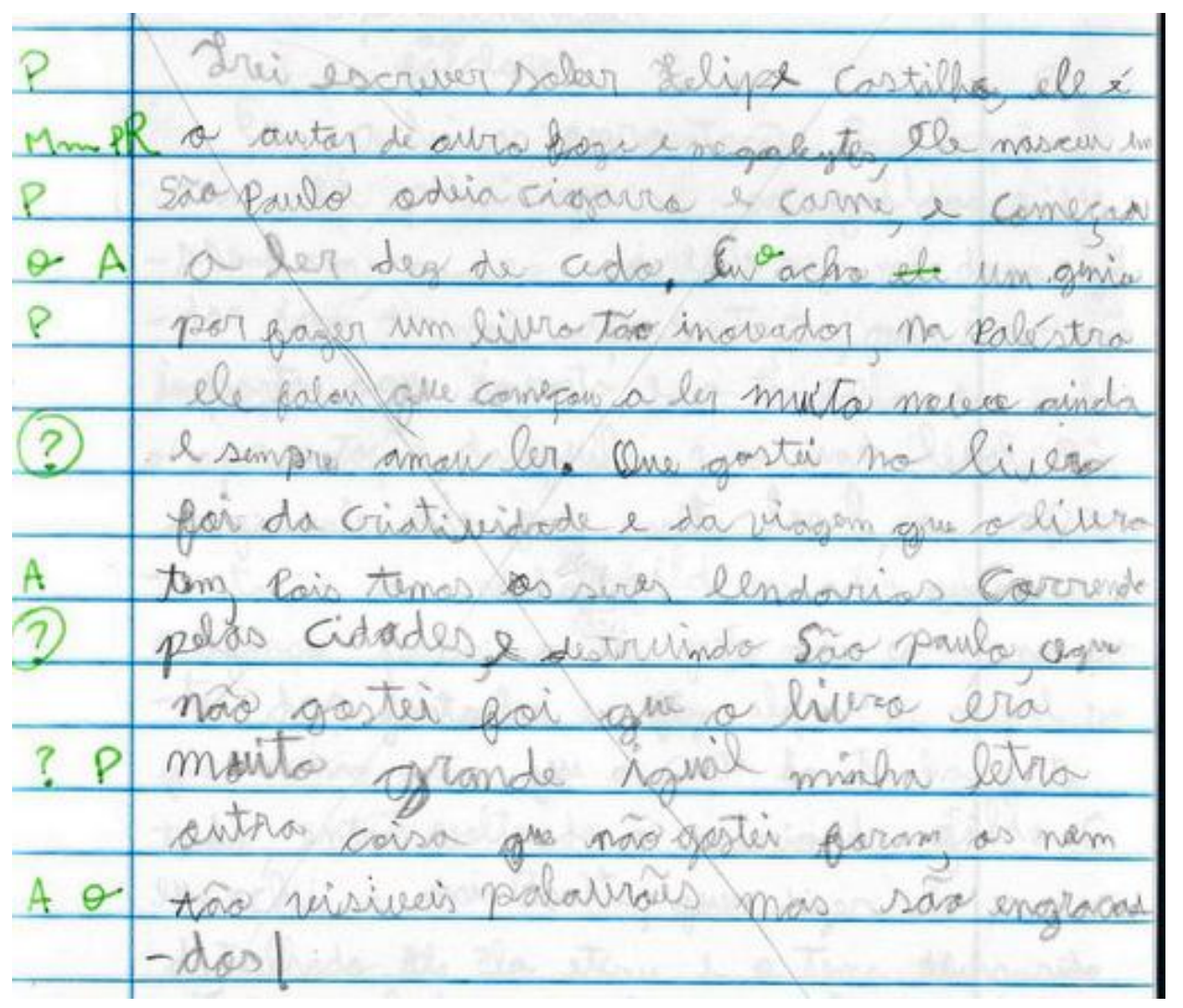

Figura 34:Texto 1 de 3 de AutorB14. 


\section{Noteos Grupos:}

Na minha opinico ell nulca gostei de Mudansas, en gostava dos guildas ontigas Mas sempere figues pensando isto vai un dia acobar.

Wtó gue as novers guildos mo soo too ruins assio, só gue como sempre temo. problemas de entrozomento, principalmante can a vilamaior oule sampre acha gus us estar

Chuttand. In acabe tendo digieuldader Quando houre a sortivo do contoo prosente, en so pigni empolgade em sebr que minko velho quildo ganhor,

Mas espero gus a minha nolea aril - da seja ben mellar que a antioa, sé

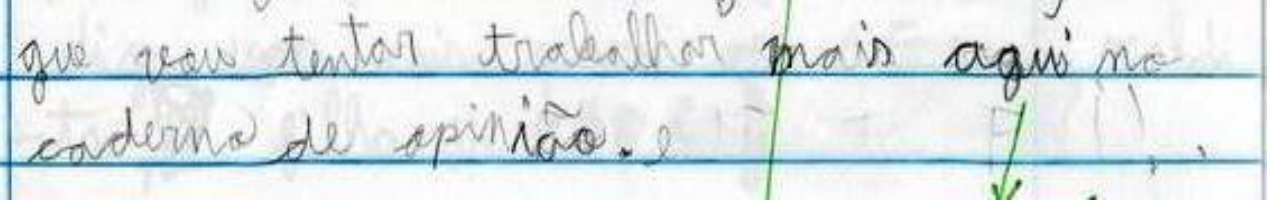

Figura 35:Texto 2 de 3 de AutorB14. 


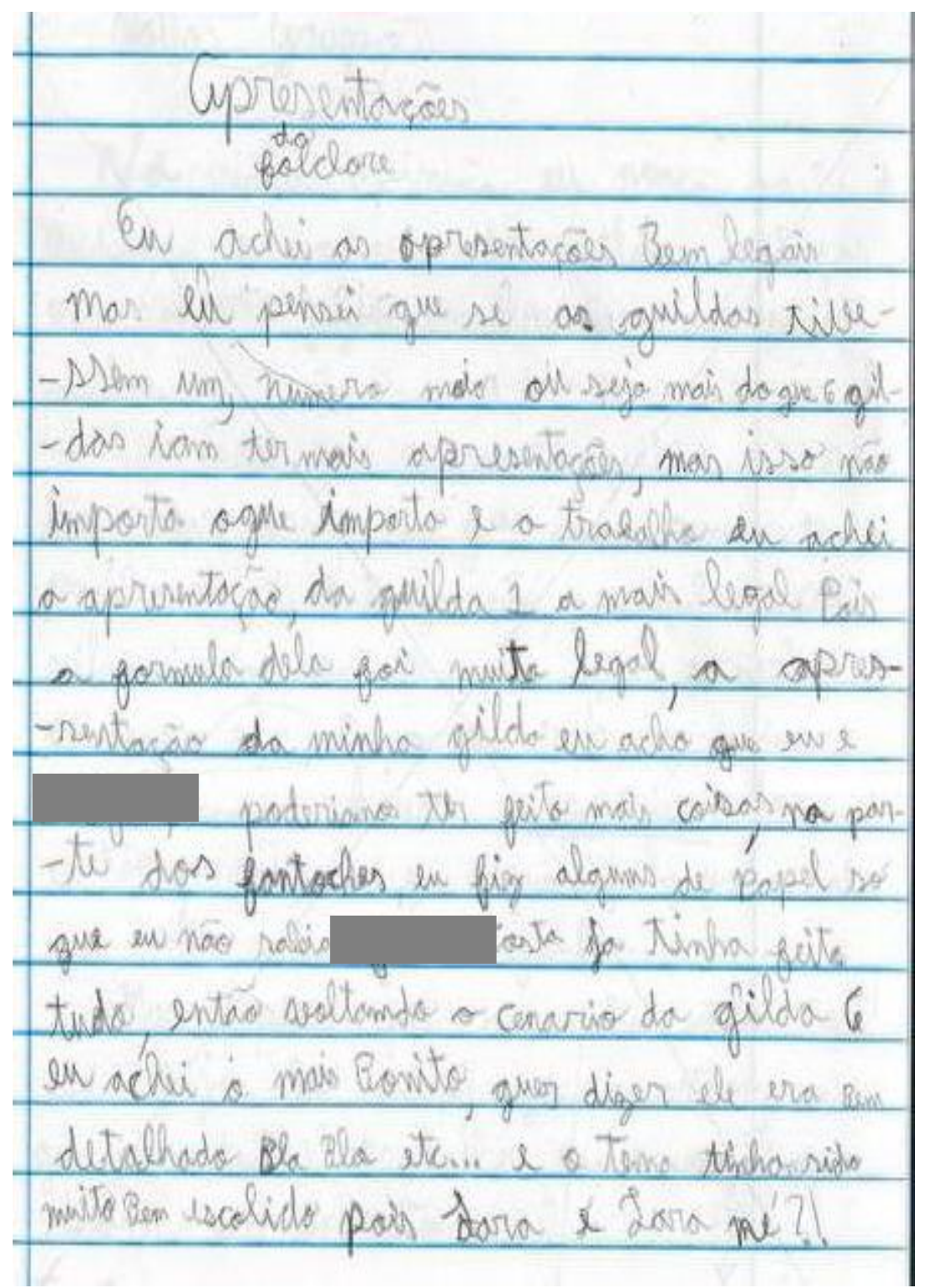

Figura 36:Texto 3 de 3 de AutorB14.

\section{Evolução}

(Já estava no nível adequado ou acima, mas não apresentou um crescimento significativo em algum aspecto.)

AutorB34, desde o início, era muito acima da média de um aluno de $6^{\circ}$ ano.

Cumpriu todas as tarefas com louvor. Era metodicamente bastante dedicado. Sua lacuna de aprendizagem não estava na construção textual ou qualquer questão referente ao intelecto (racional) nem também na capacidade de expressão de opinião. Dessa forma, na aprendizagem formal da escrita nem tinha como ter uma evolução visível naquele momento porque sua competência já estava muito além. Ele precisava aprender, no entanto, a trabalhar em grupo, a dialogar, a dividir as 
tarefas e a não querer realizá-las sozinho e do seu jeito com seu perfeccionismo. Passou por sérias situações nesse sentido e não tenho certeza se, de fato, aprendeu, ou apenas arranjou um meio de sobreviver àquela experiência.

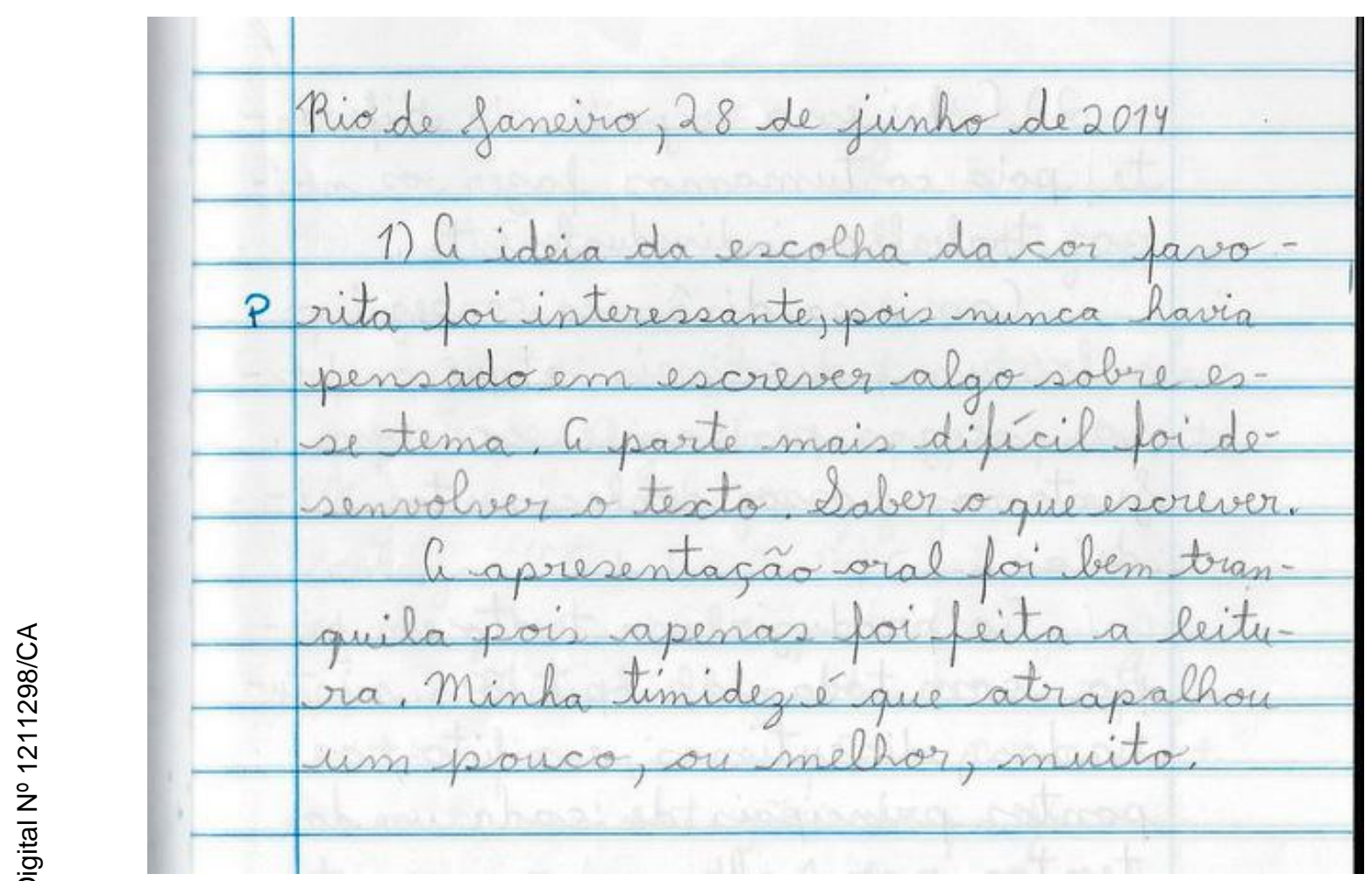

Figura 37:Texto 1 de 2 de AutorB34. 


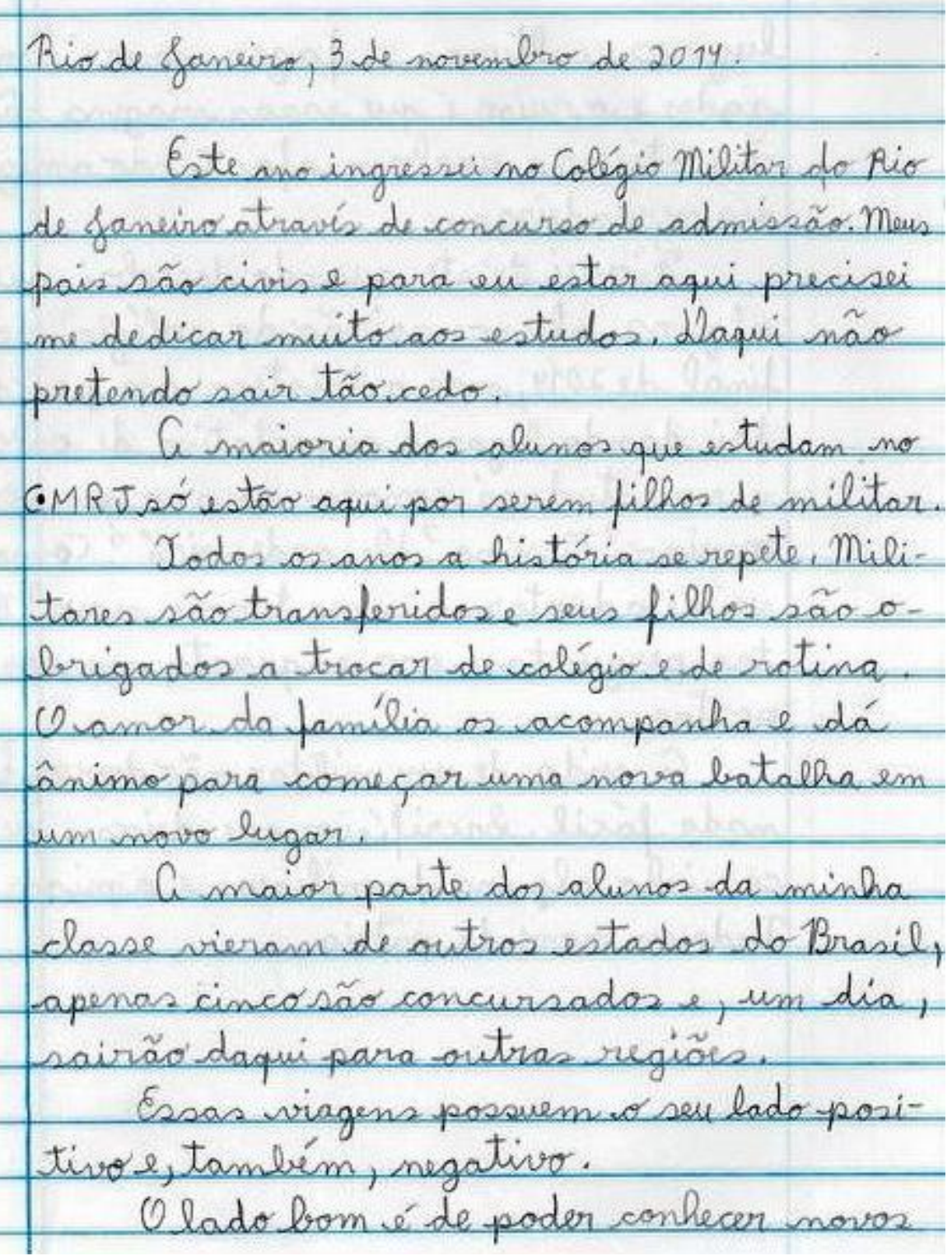

Figura 38:Texto 2 de 2 de AutorB34 (parte 1). 


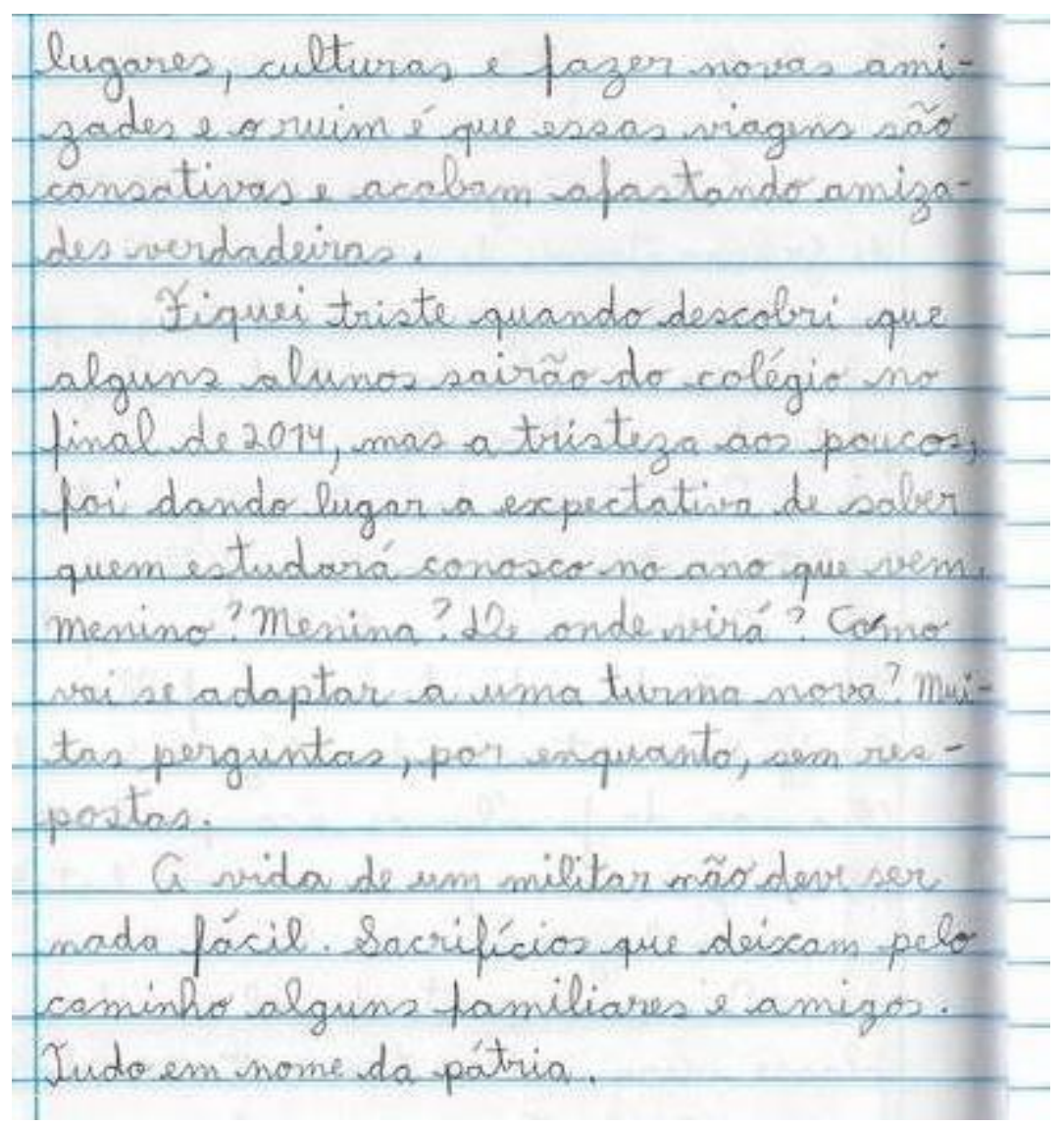

Figura 39:Texto 1 de 2 de AutorB34 (parte 2).

\section{Evolução}

(Já estava no nível adequado ou acima e melhorou em algum aspecto.)

AutorA39 escrevia o esperado para a sua idade. Alguns pequenos problemas com pontuação e ortografia, mas nada incomum ao ano. Fazia todas as tarefas e sempre procurava melhorar em suas reescrituras. $\mathrm{O}$ foco de sua evolução foi no amadurecimento da expressão da opinião, pois houve um crescimento na sua capacidade de se posiconar. $\mathrm{O}$ que antes ficava um pouco restrito ao enunciado, ao que se pedia ou ao que eu falava, com o tempo foi ganhando autoria e se libertando para expressar suas próprias ideias. 
159

Cchei interessante quando cada aluno. Fv pode expressar a razäo por preferir uma certa are, pois assim racé R podé expressar sua próp reva opinião anis aviria de seus colegas

CWuando suzemos o trabautho em up cor achei legal pos desta forma

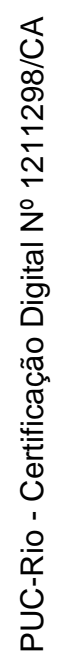
rocé pode trabalhar com a sua préprea openià e a apinicio de sua equipe.

Figura 40:Texto 1 de 2 de AutorA39. 


\section{Minha Opinião}

Não gosto dessas mudan cas -miertares, ján me mudri muito. (1) único lado positivol disso él que toré conhere pesseas movale, calturas diferentes el lugares novios.

Meu pain ester ano foí dé ima conessä nowerctervion pela ONI no Congo e não gosere muito disro. Fico um bom tempo sinn ré - 10 pessoalmente, somente por Skype.

Qgora nowo irei mais me roundor, pois meu pai pode acabar sendo transferido para outros estadas e minha máe trabalha mo RJ.O trabalho dela éaxpicomo psicóloga do bombeiro. Sabendo disro fico masoss tranguila de saber que finalmento nčos brei maies me emudar. Síco tiuste de estar ciente que

Figura 41:Texto 2 de 2 de AutorA39 (parte 1).

taluez nunca maisiveres alguns amigor, mas dá pra se comuntia por diversos meios. Sec quée estadiando no CM'RJ drei nentín. ainda meálo iésso, porén vão se Chegam plessoals; sempre vou ebtar conhecendo gentie nova \& isso é interessandon, poís evóé oup rende com estes com pouco de in scaca cultura.

Figura 42:Texto 2 de 2 de AutorA39 (parte 2). 
Creio que esses exemplos podem demonstrar um pouco do que vivi na estratégia realizada. A minha interação com cada aluno se baseava, acima de tudo, na afetividade, no (re)conhecimento dele como pessoa, como indivíduo. O lúdico, que muitas vezes pode parecer algo meio subjetivo, para aqueles que têm uma visão mais racional do processo de ensino e aprendizagem, deu destaque a uma interação afetiva que, segundo Santos e Cruz (2011, p. 12) "ajuda mais a compreender e modificar as pessoas do que um raciocínio brilhante, repassado mecanicamente".

Mas, onde está, de fato, o lúdico em um trabalho como esse aparentemente “tão tradicional”, em que o aluno escreve e o professor corrige? O lúdico está nas propostas temáticas que levaram em consideração a vivência do aluno, suas experiências. O lúdico está no interesse e na confiança gerados na construção do texto, porque o aluno não só pode falar/escrever, se expressar e dizer as suas verdades sobre tudo o que está sentindo e vivendo, como também é ouvido/lido e respeitado em sua individualidade. De acordo com Maia e Coimbra (2014, p. 99), o lúdico "abre espaço transferencial para que angústias, alegrias, tristezas, dúvidas das crianças sejam projetadas". Tenho certeza de que essa estratégia lúdica, mesmo com os inúmeros problemas e dificuldades com que me deparei ao longo de todo o processo, proporcionou a mim e aos alunos uma interação bastante personalizada e um desenvolvimento final positivo. Como disse o pequeno AutorA44,

O que mais me chamou atenção foi o caderno de opinião, que nos ajuda nas correções e dando a possibilidade da professora nos conhecer melhor e mais detalhadamente.

\subsection{Escrever; escrever e pensar; pensar e escrever: urge refletir sobre a competência para se expressar}

Segundo Alves (1994, p.84),

aquilo que um dia eu não sabia me foi ensinado; eu aprendi com o corpo e esqueci com a cabeça. E a condição para que minhas mãos saibam bem é que a cabeça não pense sobre o que elas estão fazendo. Um pianista que, na hora da execução, pensa sobre os caminhos que seus dedos deverão seguir, tropeçará fatalmente (...).

Paín (2009) explica que a escrita, apesar de toda a sua elaboração e complexidade, pode tornar-se, num certo momento automatizada, já que a 
inscrição ocorre no nível do organismo. Ela exemplifica isso comparando-a com a linguagem:

Ao falar, não pensamos na linguagem, falamos. Quer dizer que, num dado momento, isto fica inscrito organicamente. A prova é que se alguém sofre um traumatismo craniano em certas zonas, perde a possibilidade de relacionar a palavra com o significado. Portanto, isso está materialmente registrado, no nível orgânico. (PAÍN, 2009, p. 64)

Mas para que a automatização ocorra, é necessário investimento na prática, também por meio da repetição e da constância. Paín afirma que "quando a criança alcança um nível de escrita suficientemente fluente, de tal modo que não precisa pensar no traço, ela automatiza a escrita". (PAÍN, 2009, p. 64) ${ }^{50}$

Mais uma vez tomo sua referência para ir além e atingir meu público de pesquisa com faixa etária entre dez e doze anos. Há alunos que, mesmo nessa faixa etária, ainda não apresentam o traço definido (exemplo abaixo na Figura 13) nem com certa plasticidade (Figura 14), portanto entende-se que a escrita não esteja suficientemente automatizada. E há alunos com traços bem definidos e firmes (Figura 15)

Escreva a sua opinião sobre como foi este bimestre para você com relação às aulas de Língua Portuguesa. Apresente o que você achou de positivo e o que houve de negativo nas aulas, atividades etc.

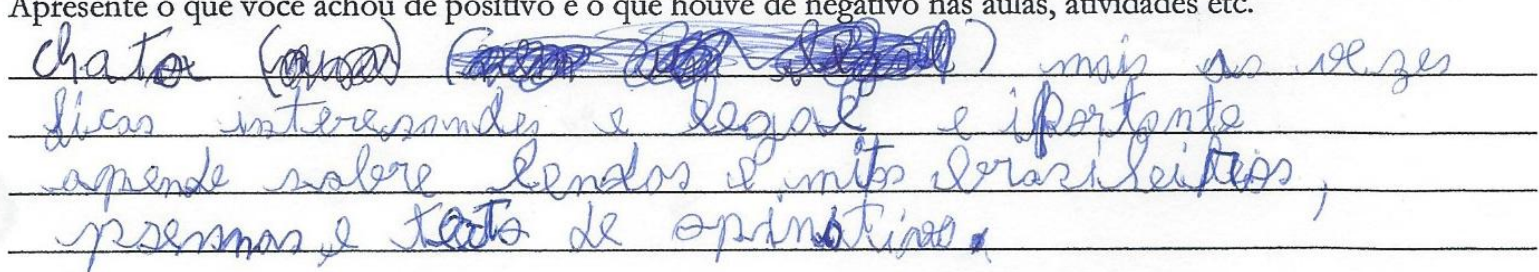

Figura 43: Letra do AutorB17, com problemas no traço pouco definido e na construção textual fluente.

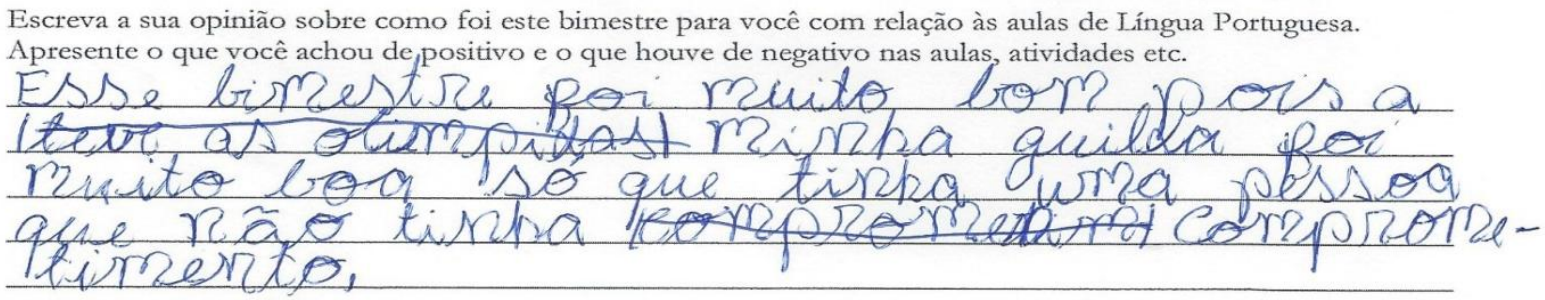

Figura 44: Letra do AutorB1, com problemas na plasticidade do traço (ainda há certo tremor).

50 Trato aqui da atividade manuscrita, mas considero relevante ressaltar e deixar claro que a importância da automação da letra, na atualidade, tem um limite. Sabemos que, cada vez mais, com o advento das mídias digitais e da futura (presente?) alfabetização com tablets, computadores ou quaisquer outros gadgets, a escrita cursiva vai ser, aos poucos, provavelmente, eliminada. $\mathrm{O}$ que importa, na verdade, é a "automação" da construção do texto "na cabeça". 
Escreva a sua opinião sobre como foi este bimestre para você com relação às aulas de Língua Portuguesa. Apresente o que você achou de positivo e o que houve de negativo nas aulas, atividades etc.

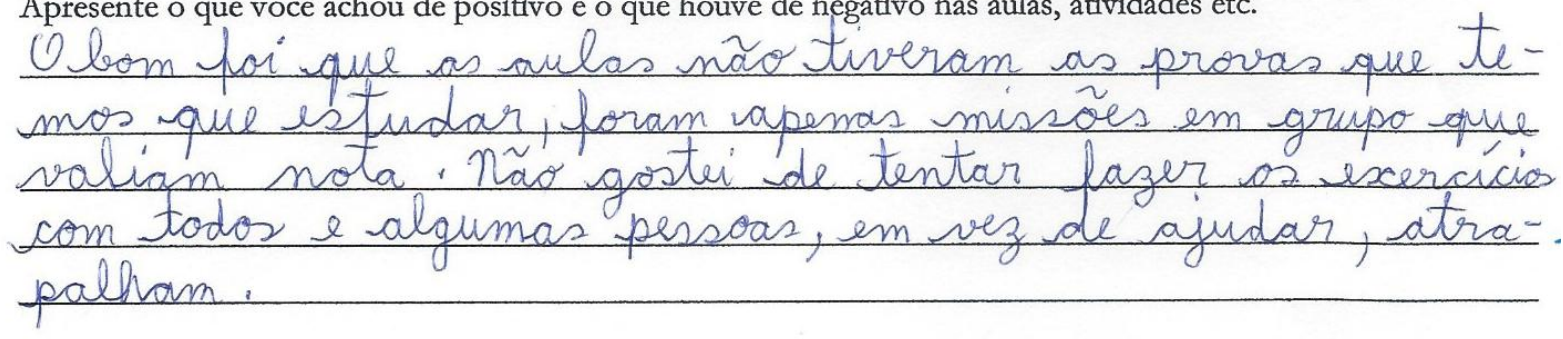

Figura 45: Letra do AutorB34, com traços bem definidos e firmes.

Mesmo que tenha de levar em consideração a maior ou menor prática cotidiana do manuscrito pela criança, hoje mergulhada em escritas digitais, trago essa comparação por me deparar com casos como AutorB17 que, embora tenha algum conteúdo no exemplo apresentado acima, nunca conseguiu completar uma redação sequer.

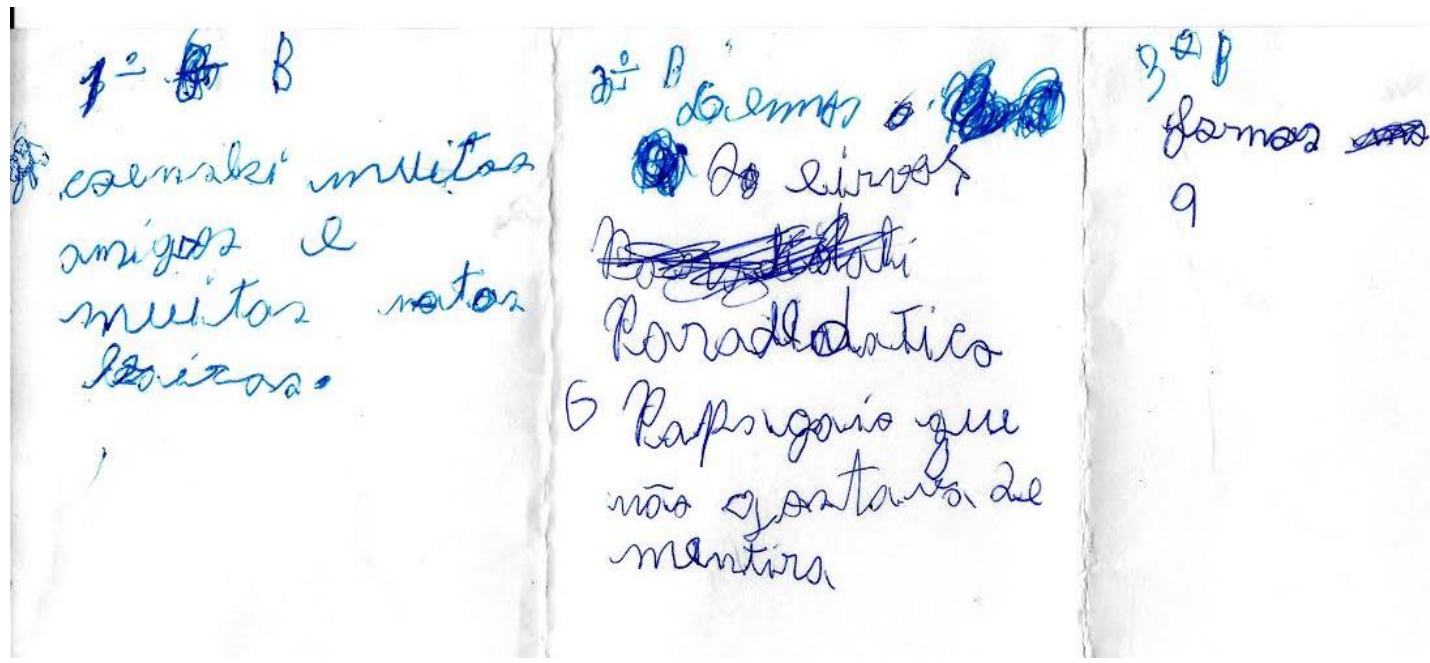

Figura 46: Trabalho de memória do ano do AutorB17.

AutorB17 pouco escrevia e também apresentava grande dificuldade de se expressar oralmente, diferente do aluno AutorA12, que apresentava enormes problemas de alfabetização e total dificuldade de expressão escrita (embora no questionário do início do semestre tivesse dito que adorava escrever), mas era brilhante na oralidade ${ }^{51}$. Levanto, então, uma questão que muito me incomoda: se a escrita de certos alunos não está de todo automatizada, ou melhor, ainda demanda o "saber como é", não é uma competência estabelecida, como posso

\footnotetext{
${ }^{51}$ Infelizmente esse aluno foi reprovado porque a escola ainda hoje se baseia em um equivocado processo de avaliação restrito à escrita. Sua capacidade de argumentação oral era destacada não só por mim, como também pelo professor de Geografia.
} 
exigir que eles evoluam para uma escrita reflexiva com uma maior capacidade interpretativa? ${ }^{52}$ Esse é mais um grave problema que encontramos na escola para todos. Há grande distinção entre as crianças em uma mesma turma e o professor não pode, assim, realizar um trabalho sem considerar as particularidades, o indivíduo, principalmente pela realidade de alunos tão heterogêneos em nível de aprendizagem.

Acredito haver níveis dessa automatização e isso, em parte, foi o que busquei no processo de escrita constante e com feedback personalizado. A automatização da escrita vai muito além do processo de alfabetização. Para alguns alunos eu tinha de proporcionar situações para o desenvolvimento do hábito de escrever sem pensar que estava escrevendo. Paín (2009, p. 65) diz que "só depois, quando automatizamos isso, poderemos pensar na interpretação, dar mais cor a uma nota, prolongá-la etc. Uma parte tem de se automatizar para que a outra parte venha a aperfeiçoar a anterior", pois só se constroem novos conhecimentos sobre uma parte já automatizada. Para outros alunos, era necessário possibilitar a prática constante da escrita para desenvolver o ato de escrever em si, pensando no que estava escrevendo a fim de avançar e possibilitar a construção de um estilo próprio de se posicionar e de refletir sobre o mundo que os cerca. Isso é um processo bem longo, que pressupõe uma prática constante que deveria ser o mote maior da escola. Maia (2014) afirma que ao conseguir expressar seu pensamento por meio de alguma forma de linguagem, a criança sai de uma posição cristalizada anterior para inquirir o que está ocorrendo no ambiente.

Deixo claro, porém, que a minha proposta não se amparou numa questão quantitativa, o que poderia levar a uma prática do manuscrito com letra inteligível. Não é a quatidade de redações que torna o estudante com a habilidade de escrever com competência. O incentivo foi sempre de cognição, e não de repetição pela repetição. Entretanto, o que percebo que aconteceu foi que, ao fazer mais redações, isto é, com mais atividades escritas, com um fim que não era a própria escrita, mas a expressão da opinião, com bastante liberdade para se expressar e dizer o que pensava e sentia, o aluno teve a oportunidade de passar do terreno

${ }^{52}$ Refiro-me aqui especificamente à escrita porque foi o meu maior enfoque nessa pesquisa, embora tenha buscado desenvolver atividades de expressão oral ao longo do semestre por entender que o importante, como já disse, não é a automação da escrita em si, mas a "automação" da capacidade de pensar e organizar o discurso. 
sensório-motor da escrita que ainda se ampara no observar, no identificar, a fim de realizar a escrita, para o terreno da automação, realizar sem pensar. Em outras palavras, ele teve condições de colocar a sua atenção, e o seu observar em outros pontos, como a reflexão temática sobre o que iria escrever.

Esse processo se concretiza também porque a proposta de trabalho não é única, isto é, não é geral, para todos. Creio que posso fazer uma grande diferença em atividade única e trabalho único. Eu propunha uma atividade única, mas respeitava as individualidades, dialogando com cada um em seus textos e conhecendo cada um em suas particularidades.

\subsection{A busca por aprender a aprender estudar}

Numa instituição pública como a que realizei minha pesquisa, a variedade de origens, de construções familiares, de credos, de valores, torna a sala de aula cada vez mais plural em experiências, mas também em recursos para uma (boa) aprendizagem. Por esse motivo, cada professor, em sua disciplina, tem de partir do fundamental em cada ano: como estudar? O que fazer para desenvolver tais e tais aprendizagens específicas? (MACEDO, 2008)

Conteúdos diferentes pressupõem métodos de estudo e práticas diferentes. Portanto, ouso dizer que o professor não pode mais "jogar" sobre o aluno a responsabilidade de sua não-aprendizagem por não ter praticado inúmeras vezes determinados exercícios, ou por não ter lido com atenção determinados capítulos do livro didático ou, ainda, por não ter respondido o que se perguntava nas questões apresentadas (lógico que essa questão é bem delicada e há casos e casos nessa seara das responsabilidades). Cada indivíduo pensa e aprende de modo diferente do outro, principalmente porque cada indivíduo carrega uma bagagem prévia diferente do outro.

Tendo essa visão de que aqueles alunos precisavam também aprender a estudar, resolvi desenvolver um Estudo Dirigido sobre o Artigo ${ }^{53}$. Na verdade, como já disse, juntei uma inabilidade minha para criar algo mais dinâmico para esse conteúdo específico, com a necessidade de promover uma atividade de estudo mais formal, com atividades seguidas de leitura, pesquisa,

\footnotetext{
${ }^{53}$ Toda a atividade relacionada ao Estudo Dirigido sobre o Artigo foi relata no capítulo 5.
} 
organização/entendimento de conceito, prática de exercícios a fim de solidificar a aprendizagem, com direito a repetição para ratificar o aprendido.

A realização do processo como um todo não foi fácil. Encontrei alguma resistência por parte de um bom número de alunos que desejavam voltar para as atividades que proporcionavam mais diversão. A "professora tradicional", num primeiro momento de análise fria, especulou que os estudantes estavam descompromissados e desinteressados. No entanto, a pesquisadora, de posse de algumas leituras norteadoras buscou um novo olhar. Então, para que esse estudo se realizasse a contento e todos entendessem e se comprometessem realmente com a proposta, tive de refazê-lo outras duas vezes após a atividade realizada em sala.

Macedo, Petty \& Passos (2007), baseando-se em Piaget já apresentado por mim no capítulo 2, afirmam que o lúdico está ligado à relação da criança com a tarefa a ser realizada pelo prazer funcional que desperta. Mas esse prazer vai depender do sentido que a atividade em si tem para a criança. É necessário que a proposta seja clara, direta, simples (sem ser banal), adequada ao tempo e ao espaço, desafiadora e que o contexto aprove. O problema, no entanto, é que mesmo que todas essas qualidades estejam corretamente ajustadas à atividade, sempre poderá haver alunos que não serão sequer "despertados" para terem a possibilidade de sentir esse prazer, simplesmente pelo fato de não terem as condições básicas para se colocarem abertos à sua realização ${ }^{54}$. Temos de lidar com as inúmeras situações possíveis para um mesmo problema: o não cumprimento das propostas a contento.

Vejo, pela observação atenta dessa experiência que vivi, que a necessidade de segundas chances e de uma percepção clara do aluno não como desinteressado, "vagabundo", preguiçoso, mas como aquele que, não tendo os recursos básicos para sua aprendizagem, precisa de orientação constante, interação pessoal aluno(indivíduo)-professor, e não professor-turma, se tornam cada vez mais fundamentais numa escola que se diz para todos. É necessário lembrar o que

${ }^{54}$ Dois alunos (AutorA7 e AutorB15, respectivamente) tinham o costume de não realizar tarefa alguma de casa ao longo de todo o ano (inclusive mencionaram isso no questionário de perfil de estudo). $\mathrm{O}$ incômodo gerado com a nova estratégia foi exposto:

O que eu achei de mais positivo foram os livros e as organisações em guilda mas oque eu achei que a ideia de ter dever de casa que vale nota foi horrivel pois não gosto de fazer dever de casa.(A7)

Não gostei das aulas de português, nem das guildas, porque não gosto deste metodo de ensino adotado NÃO. Porque não gosto de trabalhos/avaliações mandados para casa valendo nota.(B15) 
aprendemos com os jogos. De acordo com Gee (2010), há diversos jogos em que o único modo de aprender a jogá-los para alcançar o objetivo final é jogando e experimentando inúmeras vezes, fracasso após fracasso, até atingir o sucesso. E no lugar de uma experiência negativa, depreciativa e de menos-valia, o jogador sai fortalecido com as variadas experiências e situações de aprendizagem. Paín (2003, p. 70) diz ainda que "temos de dar um passo atrás, levar a criança a fazer experiências com a estrutura que tem, até que ela acumule o necessário para sua consecução.” E entendendo essas questões, procurei assumir o papel de professora orientadora, de acordo com o que defende Macedo (2008).

Foi possível constatar com essa atividade aquilo que já está mais do que percebido pelos criadores de jogos de videogame e que transforma suas criações em atividades apaixonantes, onde a falha, o erro e a "morte" não são motivos para a desistência na maioria dos casos: o feedback positivo.Se dermos uma nova chance ao aluno, ajudando-o a perceber claramente em que está falhando e em que precisa melhorar (esse é o foco de transformação, não é a chance pela chance), ele terá condições de refazer o caminho e crescer. Mas sem a orientação, esse processo fica muito mais difícil e, na maior parte das vezes, desestimulante. Morgon (2013, p. 98) diz que "o lúdico nas avaliações pode estar também na valorização dos erros". E acrescenta em seguida que

valorizar o erro é compreendê-lo como essencial para o avanço do conhecimento, já que podemos aprender muito com a análise de nossos próprios erros e com a possível compreensão (e consequente superação) de obstáculos frequentes. Um aluno capaz de examinar seu trabalho, autoavaliar-se e de valorizar seus erros, pode crescer muito, ainda mais se compreender a importância de críticas, da mudança de opinião e da escuta do outro.

Esse crescimento passo a passo foi quantificado. A primeira avaliação feita com base no estudo dirigido teve a média 4,2 nas duas turmas, abaixo da média do colégio que é cinco. Após todo o feedback apresentado e com a nova chance sem ameaças, dívidas ou rancores, essa média subiu para 6,7.

Sustento-me, assim, em Gee (2010) e Paín (2003) para transformar a professora tradicional numa professora que se forma para uma escola para todos. É necessário significar sempre repetidamente, dar novas chances, criar situações concretas de aprendizagem, esperar a automatização de uma aprendizagem para o desenvolvimento de outra, afinal

todos os homens são inteligentes e todos têm direito à inteligência. Isso significa que não devemos nos embrutecer, mas dar vazão à inteligência que todos têm, 
porque essa é uma capacidade de todos para poderem relacionar-se como seres humanos. Não se deve classificar dizendo este não dá, o outro dá. Não. Todos temos essa estrutura que nos permite aprender. (PAÍN, 2003, p. 70)

Por tudo isso, depois de tudo que experimentei e vivi, as palavras e expressões que se destacam para mim como fundamentais nessa transformação de minha prática docente são: ouvir, refletir, dialogar, dar feedback constante, orientar, dar novas chances de aprendizagem. Uso esta úlima expressão, no entanto, sempre com um certo receio, pois em minha experiência como professora, nas diversas instituições em que atuei, já vi a leitura de "novas chances" como um aumento do número de testes ou provas simplesmente para que o aluno consiga tirar uma boa nota. Isso de nada adianta! Não é a quantidade de avaliações, mas a qualidade do feedback e das interações. A chance a que me refiro deve sempre se realizar na aprendizagem em primeiríssimo lugar. 


\section{A culminância da experiência: discussão dos dados (parte 2)}

O sujeito mais importante de uma escola deve ser sempre o aluno. Ouvi-los, de fato, e conhecê-los é uma necessidade. A discussão dos dados neste capítulo se baseia, prioritariamente, nas opiniões e representações dos alunos sobre as práticas escolares a que são submetidos.

\subsection{Os alunos têm muito a dizer. Queremos ouvi-los?}

Como já disse repetidamente, foi um semestre inteiro de produção, de criação e recriação, muitas atividades, muitos trabalhos práticos em que os alunos colocaram "a mão na massa" e escreveram muitos textos, desenharam e ilustraram, falaram uns com os outros e comigo, criaram jogos, HQs, fantoches, discutiram questões, brincaram e riram, exercitaram construções, leram muitos textos em diversidade de gêneros e de linguagens (verbal, visual, mista), se interessaram, pesquisaram em livros, dicionários e na internet, representaram, atuaram. Seria impossível neste espaço analisar e discutir todas as produções de oitenta encontros. Por esse motivo, tomei a liberdade de selecionar alguns pontos que me pareceram não só interessantes para uma discussão da escola que temos hoje em relação à escola que queremos (queremos?), como também importantes na minha leitura e autoavaliação como professora em minha prática docente. Aliás, essa pesquisa que teve início com a estratégia em se pensando na transformação da escola e na aprendizagem do aluno se confirma, similarmente, como um processo reflexivo de minha atuação e da prática docente.

A análise crítica do segundo semestre de 2014 repousa em pontos que considerei de grande importância em minha pesquisa: a autoria na construção da opinião, o sentimento de grupo e a tentativa de manter direto o lúdico na sala de aula. 


\subsubsection{Sobre construção da opinião: em busca da cidadania}

Como já afirmei anteriormente, investi em uma produção textual frequente do aluno com feedback intensivo do professor. O docente de LP ensina diversos gêneros textuais ao longo de um ano letivo. Infelizmente, porém, o aluno tem poucas oportunidades formais de prática textual completa de cada gênero em sua vida escolar. Motivos para essa pouca produção textual há vários, desde o ultrapassado costume e tradição de um ensino da Língua Portuguesa pautado na Gramática, com base na análise dos termos, até as totalmente justificáveis questões referentes ao difícil trabalho docente: elevado número de turmas (muitas vezes para se obter um salário minimamente digno) e a quantidade de alunos por turma (o que aumenta, consequentemente, o número de redações a corrigir). Embora quantidade de produção não seja sinônimo de qualidade na aprendizagem, o resultado dessa junção desastrosa costuma tender a piorar a formação discente com a quase total falta de prática escrita para o desenvolvimento da competência discursiva do aluno. Isso fica ainda mais visível se compararmos escolas privadas de elite, que dispõem, na maioria das vezes, de corretores de redação contratados por demanda para corrigir e dar um feedback avaliativo das produções textuais semanais dos alunos da instituição, com as escolas privadas ou públicas cujo trabalho é exclusivo do professor da turma.Diante dessa situação, para mim, no mínimo, constrangedora, na distinção de uma escola seletiva para uma escola para todos, precisei atuar com uma concreta mudança de paradigma.

Em minha proposta, desejeilevar o estudante a se expressar quase que diariamente por meio do texto escrito, mas, conhecendo a dificuldade deles com os horários e sabendo que não teria como lhes dar um feedback real e rápido de tudo, temi que eles e eu também desistíssemos logo de início, desinteressados, saturados com tantas tarefas. Então, iniciei com escritas quase semanais. Dos diversos gêneros textuais do semestre (Lendas, Poemas, História em Quadrinhos e Texto de Opinião), elegi o último, pela sua importância na formação social do aluno como cidadão, para se manter ao longo de todo o segundo semestre. Volto a dizer que chamo aqui de texto de opinião algo muito mais abrangente e aberto do que o gênero escolar praticado, principalmente, nos anos finais da Educação 
Básica. O aluno de sexto ano precisa ainda aprender a se expressar, precisa aprender a escrever o que sente e pensa sobre tudo aquilo que o rodeia. Dar a opinião sobre os aspectos do mundo que vê e que influenciam ou não a sua vida. Portanto, em alguns textos, percebemos um pouco de relato, um pouco de memória, um pouco de descrição de seu cotidiano, mas em todos se buscou o olhar dele (portanto sua opinião) em relação ao que se apresenta.

Foram, ao todo, em oitenta encontros no segundo semestre, dez propostas de textos de opinião sobre diversos temas, somadas a cinco facultativas na construção das missões culturais. Dos diversos textos a que tive acesso, e ainda hoje tenho em minhas mãos os cadernos de opinião nos quais uma parte deles foi produzida, há muitos posicionamentos bastante interessantes para pensarmos uma escola para todos que dá chance ao aluno de se expressar e de se posicionar. Importante lembrar, no entanto, que esse gênero não foi o único a proporcionar produções textuais dos alunos nesse período.

Paín (2009, p.51), no capítulo que discorre sobre o "processo de aprendizagem e estruturas do sujeito para incorporar o desejo e o conhecimento do outro", apresenta que, apesar de ter todos os reflexos para sobreviver organicamente, a criança depende do desejo do outro para que essa sobrevivência se dê "no sentido humano da palavra". Diz a autora: "se alguém lhe der de comer a conta-gotas, cuidar de mantê-la limpa e com saúde, sem nada mais, a criança nunca vai se tornar um 'ser humano"”. (2009, p. 52) Estendo essa leitura do processo de aprendizagem para o processo de formação da criança na escola. $\mathrm{O}$ papel da escola tem a ver com a formação cidadã, pois para se ter direito à vida, à igualdade perante as leis, direito à liberdade etc. é necessário conhecer o que é tudo isso, entender/compreender o que é tudo isso e pensar/refletir sobre tudo isso. Penso, assim, que, da mesma forma que para a criança se tornar um ser humano depende do desejo do outro que vai lhe dar as condições básicas para isso, a criança, para se tornar um adulto que se apodere de sua cidadania, precisa do desejo daquele que assume o papel de formador, para que possa se tornar um ser humano cidadão. Infelizmente, porém, parece que a sociedade vem "alimentando" essas crianças com conta-gotas, sem nada mais, atribuindo a ela a capacidade de uma aprendizagem que, de acordo com um senso comum bastante equivocado, seria "espontânea". 
Mais ainda vou além, em relação ao "desejo do outro" e ao "conta-gotas". O desejo do outro, muitas vezes, está ligado diretamente ao professor que está na sala de aula com o aluno. Mamede-Neves (1999) afirma que é necessário um processo de identificação (inconsciente) para que o outro seja aceito como aquele que lhe confere o saber. É nesse processo de confiança e de aceitação que ocorre a aprendizagem para a autonomia (tornar-se "ser humano" e "cidadão").

No que diz respeito ao "conta-gotas", independentemente dessa identificação e transferência entre aluno e seu professor, se o docente não cumpre o seu papel de forma integral, pensando na realidade atual da escola para todos; se ele não promove situações de construção do pensamento e do conhecimento para que o aluno tenha subsídios para desenvolver-se como ser humano e cidadão, isto é, se o docente não tem o desejo (desejo dele que é o outro para o aluno/criança) de fomentar oportunidades concretas de aprendizagem, não está cumprindo seu papel social e profissional de professor. Está simplesmente permitindo a sobrevivência quase que unicamente orgânica, sem lhe dar as condições básicas de humanidade e cidadania.

Acredito que Winnicott (1998) ratifica essa questão quando diz que o professor precisa ser capaz de fornecer concomitantemente "os instrumentos e oportunidades para o pleno desenvolvimento criador e intelectual da criança, assim como os meios de expressão para a sua fantasia e vida dramática" (1998, p.34). Para o autor, as mediações do adulto para o desenvolvimento cognitivo da criança são de fundamental importância. Na verdade, faz toda a diferença a qualidade da mediação e o modo como se percebe o outro. Não adianta o professor ser competente em sua disciplina, nos conteúdos específicos que tem de ensinar, se não enxerga seus alunos como indivíduos distintos em seus sentimentos, demandas e expectativas. Além disso, o professor que está acostumado a exigir que o aluno o ouça todo o tempo, precisa também entender a importância de ouvi-lo. Aliás, Macedo (em vídeo ${ }^{55}$ ) levanta uma questão importante quando diz que "ouvir é uma atividade muito sofisticada. $\mathrm{O}$ aluno que só ouve e anota não necessariamente aprende". É preciso, então, possibilitar concretamente ao aluno situações para que ele desenvolva o pensar, o raciocinar, para culminar no desenvolvimento de um pensamento crítico. Macedo (no mesmo

\footnotetext{
${ }^{55}\langle$ https://www.youtube.com/watch?v=TgTI5gS107c $>$
} 
vídeo) ainda afirma que, numa sociedade como a que temos hoje, o indivíduo vale "pela sua capacidade de coordenar pontos de vista e de enfrentar desafios. Ao contrário disso, sua vida fica minimizada, prejudicada".

Por tudo isso, entendo o trabalho com o texto de opinião, realizado reiteradamente, como algo que vai muito além do "conta-gotas". Mesmo que não tenha havido apenas acertos de minha parte, a busca por uma construção de autonomia no que diz respeito à condição de aluno através de meu (re)conhecimento dele como sujeito que pensa e expõe o que pensa me faz acreditar que esse é o caminho a seguir.

Procurei, assim, atuar como uma professora orientadora, como define Macedo $(2008)^{56}$, porque meu objetivo não é dar aulas a alunos, mas formar estudantes para a vida toda. Segundo o autor,

o professor orientador valoriza a escrita como forma privilegiada de comunicação. Por que escrita? Porque quem faz pesquisa e não as relata, não as comunica de forma impressa (possível de ser lida, vista ou ouvida de um modo permanente), é como se não a tivesse feito. Os professores falam, os pesquisadores escrevem. Ser orientador é saber marcar a necessidade de escrever o que se aprendeu no contexto de uma investigação como algo fundamental (MACEDO, 2008 p.25).

Por isso, entendo que o desenvolvimento da escrita, da capacidade de se colocar, de exprimir opinião, de se posicionar diante do mundo que o cerca seja de fundamental importância para a vida toda, muito além do que se faz e fica na sala de aula. Acredito, ainda, que essa seja a real mudança de uma escola cuja perspectiva seja de ensino, para uma escola cuja perspectiva seja da aprendizagem.

\subsubsection{Os alunos têm muito a dizer: a autoria em construção}

A primeira expressão de opinião realizada resultou, a meu ver, no passo inicial para que pudessem perceber (para um futuro amadurecimento) que dizer o que pensa vai muito além do simples “É legal!”. Todos os alunos que realizaram essa primeira atividade opinativa ${ }^{57}$ (vinte e três na turma A e vinte e um na turma

\footnotetext{
56 "Quais são as competências requeridas para um professor orientador? Proponho que elas são pelo menos cinco. Primeiro que ele tenha a intenção permanente de formar o aluno um estudante, ou seja, alguém que desenvolva uma relação pessoal, direta e intensa com os objetos de conhecimento. (...)" (Macedo, 2008, p. 24)

${ }^{57}$ Há alunos que não fazem mesmo as tarefas e alguns fazem rapidamente sem empenho nem vontade, somente para cumprir o comando dado.
} 
B) expuseram, sem exceção, sua opinião a partir de uma lógica a que estão acostumados "pergunta-resposta". Iniciaram normalmente assim: "Prefiro o poema tal (visual ou em versos) porque..." ou "O poema que mais gostei... porque...", em duas, no máximo (raro), três linhas, sendo que onze alunos conseguiram escrever em menos de uma linha completa:

Prefiro o poema visual porque é mais bonito. (AutorB5)

Gostei mais do visual pqé desenhado. (AutorA23)

Prefiro mais o poema em verso do que o visual porque acho que o escritor pensa em muitas palavras pra escrever. (AutorB28)

Gosto do visual porque não entendo nada do que leio no outro. (AutorA3)

O poema que eu mais gostei foi o visual enterage com a pessoa e de longe e um desenho de perto e um texo. (AutorA1058)

Conforme eles liam suas opiniões em sala, antes de me entregarem para correção, eu apontava a importância de tentarem desenvolver mais as ideias que tinham. Por que é bonito? Por que o desenho lhe chama mais atenção? etc. Acredito que essas intervenções têm de ser constantes e repetitivas, para que eles consigam progredir e ampliar a capacidade de expressar suas opiniões.

Como segunda proposta, pedi que escrevessem sobre a cor favorita. Hoje analisando entendo que tal proposta de produção textual tenha sido um tanto prematura pela sua complexidade. Entretanto os produtos que tenho em minhas mãos podem demonstrar o quanto os alunos têm a dizer sobre o que pensam e sentem. Creio que é a boa comunicação entre professor e aluno(s), em um clima aberto à liberdade de expressão, que promove o desenvolvimento de uma autonomia cognitiva. E a realização desse processo também é uma grande aprendizagem para o docente no dia a dia da sala de aula.

Depois de pedir ao aluno que indicasse e justificasse qual a sua cor preferida, me dei conta de que estava adentrando num campo subjetivo nesta e em outras atividades.Solicitei a ele que expusesse algo a partir de sua subjetividade. Se isso fosse feito mais para o final do ano, após eles terem ficado à vontade $\mathrm{e}$ enturmados com as atividades coletivas, talvez tivessem se permitido uma relação com maior profundidade de troca. É provável que eu não tenha tido essa

\footnotetext{
${ }^{58}$ Com exceção do AutorA10 que realizou a tarefa atrasado, todos os outros exemplos não estão registrados no caderno que lhes dei porque eles ainda não o haviam recebido, mas durante a correção para feedback copiei, como costumo fazer, alguns exemplos por escolha própria.
} 
percepção - e já devo ter passado por várias situações semelhantes - porque não tenho desenvolvida em minha formação de professora uma competência em relação a como atuar com as subjetividades. Sobre essa questão penso que posso usar um alerta de Fortuna (2000, p. 9) que afirma ser de fundamental importância encontrar a medida ideal "entre o cumprimento de suas funções pedagógicas ensinar conteúdos e habilidades, ensinar a aprender - e psicológicas - contribuir para o desenvolvimento da subjetividade, para a construção do ser humano autônomo e criativo (...)". O docente que prepara suas aulas e as ministra elimina, muitas vezes, aspectos relevantes para se ocupar apenas da dimensão cognitiva a fim de aproveitar ao máximo as situações de aprendizagem do aluno. Porque para a escola (e isso é bastante aparente no cotidiano docente, nas conversas informais entre professores sobre alunos que não aprendem) a dimensão subjetiva não é vista, infelizmente, como constituinte no processo de aprendizagem. O que vale é o mérito intelectual. Vasconcelos (2006, p.63) ratifica isso ao comentar sobre a concepção dualista (razão versus sentimentos) do sujeito. Para o autor, "a crença nessa separação fez que se considerasse o pensamento calculista, frio e desprovido de sentimentos, apropriado para a instrução das matérias escolares clássicas". Na verdade, por muito tempo e ainda hoje reverbera a ideia de que "apenas o pensamento leva o sujeito a atitudes racionais e inteligentes, cujo expoente máximo é o pensameto científico. Já os sentimentos, vistos como 'coisas do coração', não levam ao conhecimento e podem provocar atitudes irracionais" (VASCONCELOS, 2006, p. 63).

$\mathrm{Na}$ primeira etapa dessa atividade, a individual, as produções ficaram ainda muito próximas da estrutura "pergunta-resposta" (a cor que eu mais gosto é... porque...) como apontei na atividade anterior. Isso significa que, numa leitura inicial "adestrada" ao ensino formal da LP, o professor dessa disciplina poderia fazer uma crítica ao quanto de senso comum havia nas justificativas apresentadas, sempre muito parecidas (por exemplo, a escolha do verde como a cor preferida estava associada à vegetação e à esperança, nenhum motivo exposto era ligado a algo pessoal). Tal situação, no entanto, levou-me a discutir com eles a ideia de a opinião realmente pertencer a quem está opinando, isto é, o indivíduo, e a noção da identidade de cada um (no sentido da singularidade). Acredito que, como observadora e pesquisadora, não posso me furtar a mostrar a mim mesma, com 
resquícios de "professora tradicional", que esse tipo de construção apresenta algo muito maior do aluno, que tem de ser aproveitado e explorado, embora a escola e, quando falo de escola, me incluo nela - teime em ignorar. Na verdade, a escola não "cobra" o subjetivo. Ela cobra o desempenho quantitativo de acertos. E, formados nessa estrutura, os próprios alunos não só acatam como também lutam, a todo momento, para que o professor e a instituição valorizem essas atividades mensuráveis "cartesianamente" (apesar de todo sofrimento), porque aprenderam isso desde sempre. Aliás, é muito comum a relação "vale ponto", então, é necessário fazer"; "não vale ponto", não é importante.

No olhar da professora, houve uma exceção muito interessante em uma das turmas (e eu repeti esse exemplo depois na outra), que me fez dar destaque ao aluno AutorB28. Ele havia escolhido a cor azul e justificou essa paixão dizendo que, lendo a palavra de trás para frente, vira "luza", termo que lembra seu time de coração (Portuguesa, codinome "lusa"), apesar de ser com “s”, e não com "z" da cor escolhida. Esse exemplo me permitiu, de forma bem concreta, mostrar a todos o que é ter uma opinião própria, autêntica, que sobressai ao comum. Então, a partir dessa conversa sobre a importância de ter opinião própria, e de não repetir o que qualquer um pode dizer, eu lhes pedi que reescrevessem, como tarefa de casa, os textinhos de opinião sobre a cor, observando as questões que havia levantado durante a aula. Constatei, na releitura dos textos, que muitos tinham conseguido entender o que era construir uma opinião "mais forte", com argumentos mais significativos. Vários alunos modificaram bem seus textos, conseguindo, não só desenvolvê-los mais, como também trazer novas ideias para justificar suas escolhas. Alguns, porém, permaneceram no que a "professora tradicional" considerou inicialmente superficial, o que também não pode ser condenado, já que estavam começando um processo de construção da opinião.

O que me chamou atenção também foi a falta de capricho na apresentação. Vários alunos mantiveram a escrita e a letra pouco cuidadas, no individual e depois no coletivo, com uma folha recortada sem muita preocupação estética. Acredito que essa seja uma das grandes questões levantadas por Macedo, Petty \& Passos (2007) quando fazem referência a uma escola para todos. A escola atual para todos em oposição à seletiva - tem de saber lidar com essa falta de estímulo, de interesse e de empenho. Muitos não têm em casa apoio nem referência para se 
espelhar. O que é o belo? O que é um material bem cuidado e bem apresentável, para uma criança que, muitas vezes, levanta de madrugada sozinha, arruma seu café da manhã, seu material, lava e passa seu próprio uniforme e não tem alguém que veja se tomou banho, se se alimentou direito e se não esqueceu nada $?^{59}$ Há alunos que realmente precisam de algum outro estímulo para se tornarem autores de sua aprendizagem.

No olhar da pesquisadora-observadora, porém, começou a surgir, após várias leituras e releituras das produções dos alunos, a percepção de algo bem maior. A exposição da cor preferida permitiu a eles falar sobre assuntos, de forma mais subjetiva, sem preconceitos, receios ou policiamento. Creio que o professor mais capaz para realizar seu trabalho hoje é aquele em condições de reconhecer sentimentos como o medo, o amor, o ódio, a culpa que as crianças de algum modo expressam e de lidar com isso no processo de ensino e aprendizagem.

Encontrei em seus textos:

- a morte e o medo

Preto é minha cor predileta, pois me lembra o medo, a morte e o vazio interior de uma pessoa antipática, fria e calma (AutorB8)

Eu gosto de preto porque é intença e única não tem divisões como: azul claro, azul escurso, azul marinho (...) e porai vai...

A cor preta da visão de morte, escuridão, TERROR, por isso que eu gosto de filme de terror porque não babozeira de romance com final feliz e tudo de morte, amo a escuridão com uma pessoa ama outra.(...) (AutorB20)

Gosto de preto por que me faz senti descolado representa a cor do odios e da solidam. (AutorA38)

Para mim a cor preta ela combina com tudo.

Na minha imaginação ela define a: Escuridão, o medo, a guerra e a força é muitas coisas. A cor preta não tem divisões ela não tem Preto Claro ou Preto Forte. O preto não é que nem o verde ou o azul.

Para mim não importa se a cor é feminina ou Masculina eu gosto dela assim mesmo. (AutorA37)

$\mathrm{Na}$ idade em que estão, o medo em geral, o medo da morte e, ao mesmo tempo, o prazer que esse temor pode trazer são bem significativos. Da mesma forma, a relação de ódio e de solidão são emblemáticos no sentimento adolescente de tédio constante e insatisfações.

\footnotetext{
${ }^{59}$ Havia alguns alunos nessa situação. AutorA12, por exemplo, se destacou desde o início do ano por se atrasar muito, esquecer material, chegar ao colégio sem ter tomado café etc. porque morava a maior parte do tempo apenas com um irmão que estava no Ensino Médio. Seus pais moravam em outra cidade por questões de trabalho.
} 
- as imposições sociais e culturais que precisam ser discutidas para não serem aprisionadoras

Gosto de preto porque combina, com todas as cores, deixa as pessoas magras (AutorB18)

A cor preta da aparência que você ta mais magra e essa sensação e maravilhosa, preto me acalma como outra pessoa qualquer não consegue me acalmar. (AutorB20)

Eu gosto de roxo pois, me faz sentir podesa [poderosa], bonita e importante. (...) Além de me fazer sentir magra e diferente. (AutorB27)

A imposição social parece tão forte ("ta mais magra") que AutorB20 atribui à cor que a emagrece o poder de acalmá-la como ninguém consegue fazê-lo.

Essa atividade também me apresentou alunos que, conhecendo seu comportamento habitual de antes do início da pesquisa, ao longo das aulas do primeiro semestre, se resguardaram de uma exposição de sua subjetividade atrás de regras e conhecimentos objetivos. Um exemplo:

Branco, pois de acordo com o disco de Nilton o branco é a união de todas as cores. Então essa é a minha cor favorita (das sete cores do arco-íris) e também sou um pacifista. (AutorB53)

Enxergar tudo isso e ver como são esses aspectos tão importantesquanto os aspectos gramaticais $\mathrm{e}$ formais que privilegiamos na escola e, mais especificamente, no ensino da língua materna, me faz entender que o lúdico pode trazer a transformação do processo de ensino e aprendizagem porque ele permite, ou melhor, possibilita, na descontração, a expressão da subjetividade de cada um de nós. Não posso esquecer que, desde a Antiguidade, grandes filósofos, como Platão, Sócrates, Tomás de Aquino, já tinham percebido isso, como afirma Vasconcelos (2006).

Quando a escola permite que a criança crie, brinque e fale, ela permite que o inconsciente dela se expresse, mas permite também que o seu pensamento lógico se organize e se expresse. Promovendo oportunidades concretas de expressão oral e escrita, com possibilidades subjetivas como essa demonstrada, é que a escola fomenta, de fato, a construção do conhecimento. Paín (2009, p.54), falando em relação aos bebês, afirma que

quando alguém cuida de um bebê e não o olha, nem fala com ele, esse comportamento pode favorecer uma reação autística, mas os bebês têm suas defesas, podendo mesmo seduzir o adulto. Contudo há bebês mais ou menos sedutores, e seria necessário pesquisar quais constituintes biológicos possibilitam que certas crianças sejam mais sedutoras que outras, em relação ao adulto, mesmo 
que este não as queira. Há crianças que lutam para ganhar, e outras que não lutam; isso ocorre em todos os animais. Nessa luta há uma parte que é de nível biológico, mas outra é cultural.

Tiro dessa reflexão que a escola no papel principal do professor tem de "olhar" os alunos que ali estão. Sabemos que há alunos que lutam, se defendem e saem vitoriosos, na concepção quantitativa de aprovações, ao longo dos, pelo menos, doze anos por que passam nos bancos escolares (embora não tenhamos como aferir o preço que pagam por isso em suas vidas). Há, no entanto, aqueles que não lutam (talvez porque não saibam ou não tenham forças). Com esses podemos ter uma dívida eterna se continuarmos sem "olhá-los".

Comentei anteriormente que talvez essa atividade tivesse rendido maiores frutos se feita mais ao final do semestre. Isso foi mais marcante na produção do texto coletivo realizada a partir das cores comuns escolhidas pelos alunos. A experiência como um todo foi bem interessante, mas trabalhosa. Se já é difícil para eles (e para nós também!) produzir um texto sozinho, coletivamente aumenta a dificuldade. Sobre as produções coletivas, falarei quando tratar dos trabalhos em grupo.

\subsubsection{Os alunos têm muito a dizer quando o espaço para autoria Ihes é dado}

$\mathrm{Na}$ proposta seguinte, os alunos deveriam opinar sobre o que estávamos fazendo até o momento: eles deveriam expor se haviam gostado ou não, justificando, das atividades individual e coletiva do "Jogo da cor". Mesmo sendo uma atividade de registro mais voltado para a minha pesquisa, fiz uso disso também para o desenvolvimento deles na escrita com reescritura.

Dos quarenta e um cadernos de opinião que tenho em minhas mãos, trinta alunos disseram ter gostado da atividade individual de escrita de opinião sobre a cor. São várias as justificativas, mas o fato de serem tratados como indivíduos, e não como massa, se destacou para mim. Além da necessidade que eles demonstram de poder falar, se expressar, se libertar: 
Adorei poder me expressar, poder falar o que eu acho sobre a cor verde! Quero que tenha mais trabalhos que a gente possa falar o que pensamos, nos libertar. (AutorB16)60

Gostei mais da ideia de fazer individualmente pois eu coloquei no papel tudo o que eu queria e sentia pela a minha cor preferida. (AutorA35)

Um aluno disse ter gostado e não gostado ao mesmo tempo:

Na minha opinião ter que falar sobre o que você acha da sua cor favorita é legal mas também é chato, legal porque a gente treina em expressar a opinião e chato porque tem mais tarefa. (AutorA32)

Se a "professora tradicional" pode questionar essa opinião, numa visão superficial, aparentemente "em cima do muro", a pesquisadora entende que o mundo é muito mais intricado até mesmo para as crianças. A presença de um pensamento dialético como esse mostra uma percepção que nem sempre a escola está preparada para aceitar e entender numa dualidade tão comum no mundo em que vivemos. Esse aluno, do ponto de vista do discurso, demonstra estar bem desenvolvido, porque consegue apresentar, ao mesmo tempo, a dicotomia que percebe: o bom e o ruim, intrincados. O certo e o errado, o grande e o pequeno, o feio e o bonito - dentre outros pares singularmente opostos tão presentes na formação de uma criança - precisam ser recheados das inúmeras variantes que existem entre eles e além deles, até mesmo porque é o reconhecimento dessas nuances que ajudará a criança a entender a complexidade do mundo em que vive hoje em todos os seus gêneros, cores, povos, religiões e ciências. Interessante destacar da fala de AutorA32 a noção do "dever", como um "ranço" escolar. A imposição em oposição ao que é agradável é muito forte ainda hoje na escola e criticável pelo aluno.

Parte dos que gostaram apresentou críticas que, aos meus olhos, são bastante positivas porque eles não se intimidaram em expor, de verdade, o que estavam sentindo e vivendo. Faço uma boa avaliação, nesse sentido, do meu papel como professora. Acredito que tenha conseguido a confiança e a empatia deles para, mesmo numa instituição rígida, com tanta hierarquia, principalmente para a criança que ainda está se aclimatando ao novo ambiente, eles se sentirem seguros e à vontade para informar tudo aquilo de que não gostaram. Essa confiança,

\footnotetext{
${ }^{60}$ Essa expressão de opinião me tocou muito porque AutorB16 era muito tímida, delicada, calada, com uma voz fina, com sotaque forte do Sul e um jeitinho de bebê que às vezes os colegas criticavam. Apesar disso tudo, ela demonstrou querer falar o que pensava e se "libertar".
} 
segundo Fortuna (2000, p.10), se faz pelo "brincar" (que entendo e uso aqui como lúdico). Para a autora,

o conhecimento, tal como o objeto transicional, protótipo do brincar, é uma realidade intermediária: não está no sujeito que aprende, também não está no meio ou em quem ensina. (...) Neste espaço compartilhado de confiança, o professor é autorizado pelo aluno a saber algo a seu respeito, pois quem joga, joga para alguém. O brincar permite o desenvolvimento das significações da aprendizagem e quando o professor o instrumentaliza, intervém no aprender. (...)

Então, aproveitando essa confiança, os alunos disseram:

Mas não gostei da parte oral, pois não queria ler a minha opinião (AutorB54)

Não gostei muito da ideia de falar a cor preferida na frente da sala. (AutorA52)

Eu não achei muito legal porque não gosto de falar em público, ainda mais com uma câmera me observando, mas até que não foi tão ruim assim. (AutorA23)

Essas três falas destacadas apresentam, ainda, uma questão importante: o falar em público. A educação escolar objetiva formar integralmente a criança, mas sua base formadora de grande peso se concretiza na (avaliação) escrita. Justificativas são várias, dentre elas posso citar o excesso de conteúdo a ser ministrado, a falta de tempo causada por essa extensão de conteúdo e pelo número elevado de alunos por turma (não dá para ouvir todos com frequência) e, ainda,a questão do domínio da turma (os alunos não têm o costume de ouvir seus colegas. Quando um está tirando uma dúvida, por exemplo, os outros começam a conversar, demonstrando falta de interesse). Além disso, a oralidade também é arriscada, porque carrega uma censura imediata do olhar do outro, da crítica e do riso, porque não fomos/somos formados a ouvir, a dialogar.

Não posso me furtar, no entanto, a observar um ponto referente especificamente ao desenvolvimento de minha pesquisa. O uso da câmera na sala de aula, muitas vezes, é um recurso de segurança para o pesquisador-observador, a fim de que tenha como rever e reavaliar suas observações e impressões, mas também influencia e até modifica - ao menos inicialmente enquanto se acostumam com a ideia e com a presença de um objeto estranho - as ações e as reações dos autores. O AutorA23, por exemplo, deixou isso bem claro no depoimento que repito aqui com grifo meu:

Eu não achei muito legal porque não gosto de falar em público, ainda mais com uma câmera me observando...

Mas ele mesmo parece se adequar à situação quase que no mesmo instante 
...mas até que não foi tão ruim assim.

Bem interessante também é poder observar o jeito dos alunos que disseram não gostar de falar, de se expor, de ler na frente. Os três que apresentei aqui eram crianças mais tímidas, mais envergonhadas e também bastante aplicadas como alunos. Talvez o recurso utilizado para "aparecer" sem se expor fosse pela aplicação formal nos estudos.

Seis alunos não escreveram sobre o assunto (quatro não fizeram a tarefa e dois erraram o tema: falaram sobre a sua cor escolhida).

Apenas um aluno (AutorB53 - com grifo meu), já computado nos números acima, disse não ter gostado das duas partes da atividade e ele destacou um ponto que mencionei na explanação da atividade no capítulo 4: a dificuldade de juntar algumas cores escolhidas apenas por um aluno.

Ruim, pois não entendi a finalidade do projeto, além do que você estava agrupando por cor escolhida. Então eu deveria ficar sozinho. Não via argumento para expressar nenhuma cor além do branco e preto mas achei o branco mais lógico.

Ruim, pois se não gostei do primeiro que você fez, vou gostar do que fiquei em gupo com algumas pessoas com o mesmo pensamento que eu. E não entendi o que você quis fazer.

Esse é o aluno que anteriormente justificou a sua preferência de cor com um texto frio e distante, por meio de conhecimentos teóricos sobre o disco de Newton.Ele sempre expunha uma crítica negativa em relação a tudo o que propunha, mostrando sua insatisfação. Ressalto esse aluno em especial, porque ele era bastante competitivo e se considerava muito bom em tudo. Não aceitava críticas, mas adorava criticar. Realmente excelente em Matemática, sua evolução em Português ao longo do ano foi percebida por seu pai, que esteve presente em todas as reuniões de pais com professores. No último encontro, falando em particular comigo para agradecer o trabalho, esse pai atribuiu a mim o desenvolvimento de seu filho numa área de grande dificuldade: a escrita. Ele destacou o meu incansável trabalho de corrigir e recorrigir os textos de seu filho, dialogando incessantemente com estímulos positivos, apesar de apontar seus erros e limitações e cobrar dele mudança naquilo que se repetia. AutorB53 era um aluno difícil, mas sempre procurei agir com equilíbrio e sem ironia, apesar de receber dele constantes críticas "azedas".

Penso que nós, professores, temos de buscar sempre um equilíbrio para não afastar ou até gerar um bloqueio à aprendizagem de determinada disciplina. Como 
diz Winnicott (1999, p. 49) "não poucas crianças tiveram obstruído o desenvolvimento de sua aprendizagem em função do sarcasmo do professor". Oliveira (2006, p. 80) acrescenta uma ideia que, a meu ver, ratifica o que vivenciamos no dia a dia da prática docente. Para a autora, "a escola que conhecemos pretende funcionar com a precisão do relógio, voltado para o futuro para não ver, talvez, a criança que sobrevive em cada um de nós. Por isso o isolamento das pulsões para torná-las pura razão". Como já disse anteriormente, esse aluno parece ter sido bem "adestrado" pela escola tradicional a desenvolver o intelecto e a omitir ou esconder a emoção. No item para expressão dos pontos positivos e negativos das aulas de Língua Portuguesa ao longo do terceiro bimestre, na folha de (auto)avaliação, por exemplo, ele escreve:

Diferentes, porque não estou acostumado a ter aulas assim positivamente saíamos daquela rotina normal de aula mais achei ruim algumas coisas como os trabalhos dependerem de todo mundo é você não deixar escolher as guildas. (AutorB53)

No item de sugestões, ele demonstra o porquê de seu desejo de escolher as guildas. Além disso, ratifica a questão da zona de conforto com a preferência por aulas normais:

Eu gosto de aulas diferentes e das normais a questão é que gosto delas em equilíbrio por isso queria mais aulas normais. Outra coisa são aulas que você possa escolher o grupo que vai ficar ou simplesmente passa trabalhos individuais pois alguns alunos vão acaba ficando na asa dos inteligentes assim acabam não se esforçando. (AutorB53)

O mesmo acontece na autoavaliação do quarto bimestre. AutorB53 afirma:

Eu achei as aulas de português chatas é ruim para o aprendizado de quem não sabia já que na minha opinião não teve muita explicação (suficiente)

É interessante perceber como ele sempre ressalta uma necessidade de aulas "normais", portanto, expositivas, nas quais cabe ao professor o papel de transferidor do conteúdo para que o aluno, sentado em sua carteira, ouça a explicação, copie a matéria escrita no quadro e a leve para casa a fim de ter o conteúdo organizado metodicamente para estudar.

Um ponto que considero bastante relevante para o trabalho docente no processo ensino-aprendizagem é a busca pelo conhecimento do aluno. AutorB53, por exemplo, na criação de um poema visual, também no início do segundo semestre, construiu um significativo e expressivo "Poema Espelho", com formas geométricas bem definidas e opostas: 


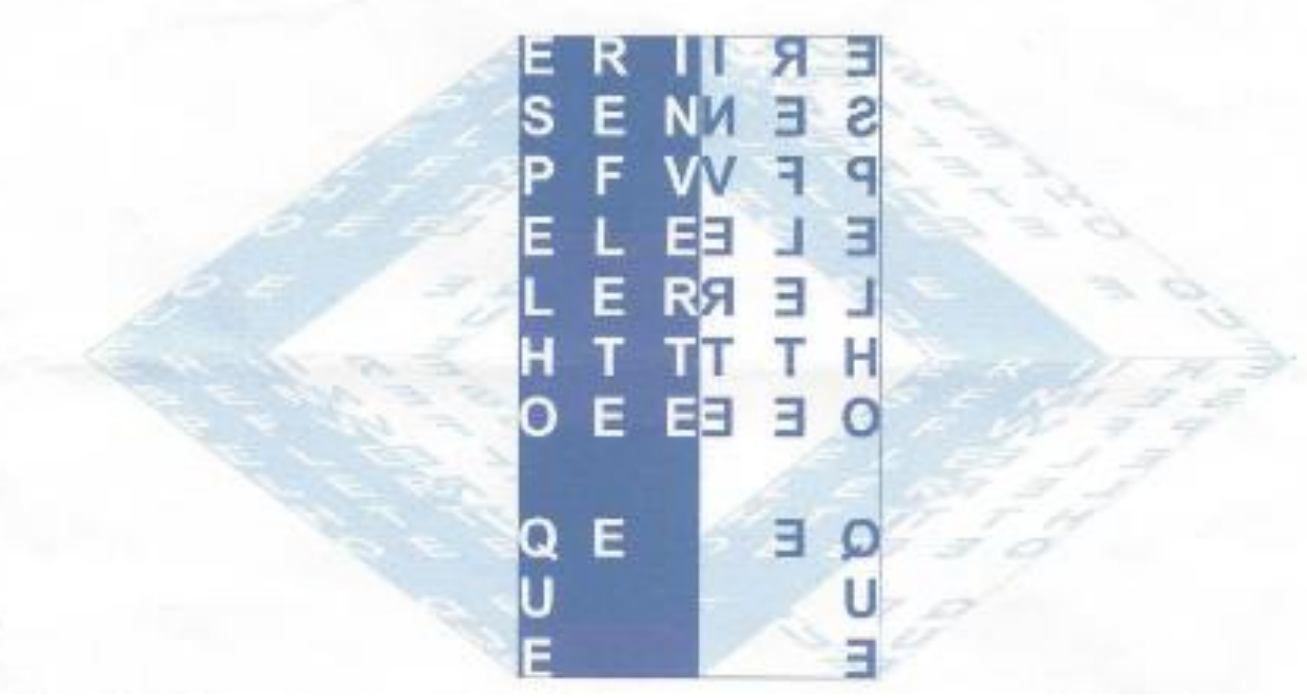

Figura 47:Poema visual produzido pelo aluno AutorB53 .

Segundo Paín (2009, p. 68-69), "as culturas individualistas em geral têm espelho, ou procuram superfícies, de água ou outros substitutos. Entretanto, na água não se pode ver o corpo inteiro e é necessária uma reconstrução". A autora diz que o corpo, além de ser a sede das coordenações sensório-motoras, é também a sede de todo afeto que reverbera, necessariamente, pelo corpo. Levanto a hipótese de que esse aluno coloca para fora, isto é, representa por meio desse poema, tudo aquilo que sentia. AutorB53 sempre preferia fazer tudo sozinho ("Então eu deveria ficar sozinho"61), não gostava de trabalhar em grupo nem de se submeter a experiências que poderiam lhe tirar da zona de conforto. Larrosa (2011), ao conceituar e explicar a palavra "experiência", demonstra a relação que causa dor, que é perigosa, que mexe, perturba, causa ferida. Segundo o autor,

a experiência é "isso que me passa". (...) A experiência, em primeiro lugar, é um passo, uma passagem, um percurso. Se a palavra experiência tem o ex de exterior, tem também esse per que é um radical indo-europeu para palavras que tem que ver com travessia, com passagem, com caminho, com viagem. A experiência supõe, portanto, uma saída de si para outra coisa, um passo para outra coisa, para esse ex de que falamos antes, para esse isso de "isso que me passa". Mas, ao mesmo tempo, a experiência supõe também que algo passa desde o acontecimento para mim, que algo me vem ou me advém. Esse passo, além disso, é uma aventura e, portanto, tem algo de incerto, supõe um risco, um perigo. De fato o verbo "experiência" ou "experimentar", o que seria "fazer uma experiência de algo" ou "padecer uma experiência com algo", se diz, em latim, ex/periri. E desse periri vem, em castelhano, a palavra "perigo". Esse seria o primeiro sentido desse passar. O que poderíamos chamar o "princípio de passagem". Mas há outro sentido. Se a experiência é "isso que me passa", o sujeito da experiência é como um território de

\footnotetext{
${ }^{61}$ Retirado do trecho transcrito na página 178.
} 
passagem, como uma superfície de sensibilidade em que algo passa e que "isso que me passa", ao passar por mim ou em mim, deixa um vestígio, uma marca, um rastro, uma ferida. Daí que o sujeito da experiência não seja, em princípio, um sujeito ativo, um agente de sua própria experiência, mas um sujeito paciente, passional. Ou, dito de outra maneira, a experiência não se faz, mas se padece. (LAROSSA, 2011, p. 7-8)

Conjecturo que, nesse trabalho, AutorB53 deixa escapar que tem de ser espelho dele mesmo. Ele não pode/quer ser complementado pelo outro. A representação parece demonstrar que ele quer ser aceito como é (não é isso que todos queremos?) e não quer se abrir à experiência com o outro (medo, timidez?).Dessa leitura tiro ainda mais fortemente a visão de que cabe ao professor conhecer bem o seu aluno para que se desenvolva, de fato, a aprendizagem. Quantos alunos perdemos, quantas aprendizagens não se realizam, simplesmente, porque não há um (re)conhecimento professor-aluno, alunoprofessor?

É impressionante como essas leituras - com a visão que tenho hoje de cada aluno, em suas particularidades, e por intermédio de seus vários escritos em que a exposição de si mesmo se fazia numa constância acima do comum para uma sala de aula - se destrincham aos meus olhos, como se os alunos estivessem aqui, durante a minha análise dos dados, gritando e me dizendo quem são eles e o que eles esperam da escola.

AutorA21 também apresentou um poema visual bastante interessante para o seu papel como estudante desta instituição:

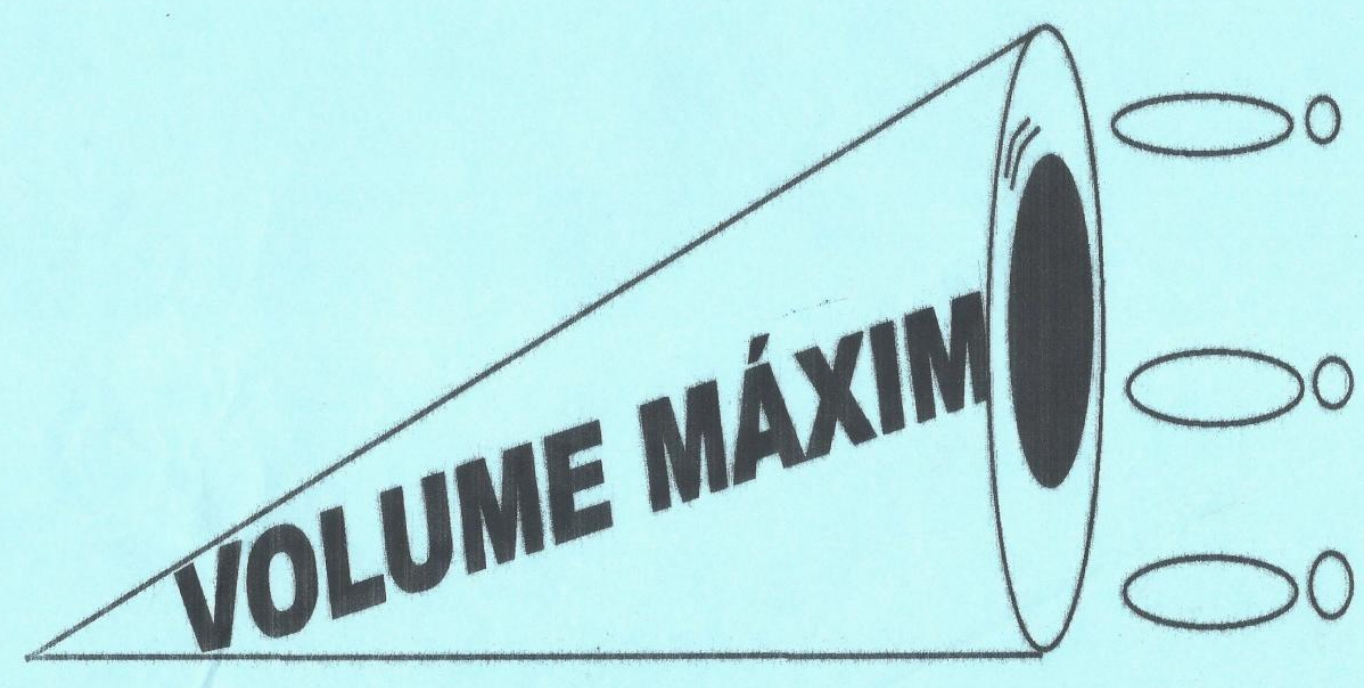

Figura 48:Poema visual produzido pelo aluno AutorA21 . 
"Volume Máximo" foi produzido por um aluno muito aplicado, mas que se sentia claramente inferior a seus colegas, sobretudo por não ter o "título" de concursado. Num colégio em que o ranking é constante e, na grande maioria das vezes, quem adquire as primeiras posições são alunos concursados, os "amparados" (filhos de militares), mesmo tendo potencial, sentem-se, muitas vezes, inferiores. Alguns poucos, porém, conseguem superar o estigma e "colocar a boca no trombone", para gritar "eu também sou capaz e quero o meu espaço".

\subsubsection{Os alunos têm muito a dizer: só "legal”, nem pensar!}

O Portal Educandus contratado pelo colégio em nível experimental não rendeu os frutos que eu esperava visto que houve dificuldade de acesso por parte de alguns alunos e problemas técnicos com a empresa contratada. Como já mencionei nocapítulo 3, as atividades que desenvolvi nesse espaço foram, então, facultativas. Mesmo assim, muitos alunos que não conseguiam publicar lá ou acessar de casa se mostraram realmente interessados e acabaram conseguindo assistir aos vídeos ilustrativos e ler as histórias na escola ou com a ajuda de colegas, entregando-me em papel suas opiniões. Isso para mim foi de grande importância porque me mostrava o quanto os assuntos apresentados de forma lúdica geravam interesse, lembrando que o lúdico não é obrigatoriamente divertido, como já apresentei no capítulo 2

Como eu me responsabilizei por produzir conteúdo de Língua Portuguesa para todo o ano no Portal, tive acesso não só aos comentários dos autores da pesquisa, mas também dos estudantes das outras quatro turmas. Isso me permitiu fazer uma rápida comparação que se mostrou positiva em relação ao trabalho que estava desenvolvendo com as minhas turmas (A e B). As imagens expostas abaixo foram recortadas por mim, do Portal Educandus, no dia 02 de agosto de 2014. Estávamos fechando a terceira semana de aulas do segundo semestre. Isto é, havia apenas três semanas que eu tinha começado a atuar em sala de aula com uma nova estratégia. Os resultados, porém, a meu ver, já começavam a aparecer. Os alunos dasturmas A e B escreveram muito além do "legal" e "muito bom" em oposição aos alunos das outras turmas.Importante destacar que eu sempre brincava em sala dizendo: “"legal' não é opinião, é preguiça mental”. 
postou em 31/07/2014 s 15:11:29

Adorei esse $\mathrm{v}$ ?deo ? bem engra?ado e legal

postou em 31/07/2014 s 20:09:32

Muito bom

muito legal

Figura 49: Comentários de alunos que não participavam da nova estratégia no Portal Educandus.

Lendo Mitos e Lendas - 2

AutorB34

A lenda da M?e do Ouro

Excluir

Achei a lenda um pouco sinistra, macabra, mas gostei porque a M?e de Ouro foi solid?ria com o escravi permitiu que ele perdesse mais um dedo de sua m?o. Curiosidades a parte: por que a M?e de Ouro pe fitas, pente e espelho? Por que 22 escravos

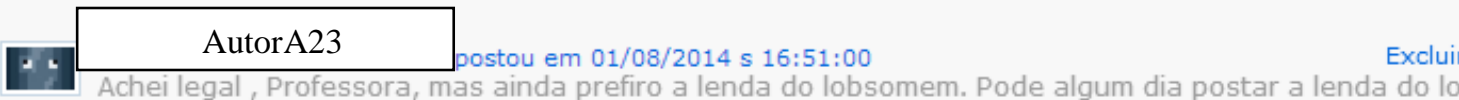
Achei bem legal a lenda mais n?o acredito que seja verdade este fato... Vou ficar que nem o Andersor Ouro,Fogo e Megabytes,s? acredito se eu ver com meus pr?prios olhos!!!

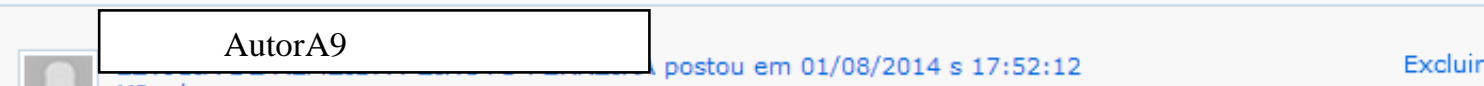

M?e de ouro

Eu gostei muito da lenda,pois ela ? muito interessante e nos faz imaginar como eu estivesse na lenda da m? e de ouro morrendo de medo,mesmo assim sabendo que ela ? do bem.

Figura 50: Comentários de alunos que participavam da nova estratégia no Portal Educandus.

Escritor Felipe Castilho

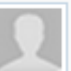

AutorB34 ostou em 31/07/2014 s 19:57:12

Excluir

A entrevista de Felipe Castilho me surpreendeu. Esperava um homem mais velho, mais s?rio. O garoto brincalh?o, cheio de gra?a e piadinhas. Fala muito e r?pido demais. Alqumas vezes tive que repetir o tr para entender o que ele havia falado. Muito doido! Valeu a pena

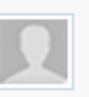
\begin{tabular}{c|c|c|}
\hline AutorA44 postou em 01/08/2014 s 14:17:27 & Excluir \\
\hline Adorei a entrevista, muito interessante, um ?timo escritor bem brincalh?o, e com uma boa personalida،
\end{tabular} gostei muito tamb?m do livro Ouro,Fogo e Megabytes, gostei tanto que j? estou lendo o segundo, que Terra e Lua cheia

Figura 51: Comentários de alunos que participavam da nova estratégia no Portal Educandus.

Penso que usar um recurso como o portal, assim como as atividades a que nomeei de "missões culturais" - que vão além dos muros da escola, isto é, que 
ultrapassam os limites de espaço e de tempo da sala de aula - nos permite vislumbrar o efeito que uma proposta lúdica pode exercer na aprendizagem. Lógico que sempre há os que cumprem a tarefa apenas por obrigação, mas há, também, os que extrapolam sendo autores de sua própria aprendizagem com prazer por esse aprender. São oportunidades que lhes são dadas. Oliveira (2006, p. 83), em sua pesquisa sobre o lúdico com base em Freud, afirma que "o conhecimento e o gosto por conhecer evoluem a partir do prazer corporal. $\mathrm{O}$ amor corporal transforma-se em amor pelo conhecimento (...)." E acrescenta que "o bom humor, por sua vez, opera de forma eficiente diante de frustrações, porque ajuda o indivíduo a resignar-se diante do inesperado e a descobrir novas saídas". Por esse motivo, acredito que a escolha das leituras, das estratégias, dos exercícios pode ter um efeito positivo ou negativo na aprendizagem.

Qualitativamente talvez eu possa dizer que sempre haverá alunos que não vão usufruir bem disso, talvez por falta de visão do futuro, falta de empatia (não é possível interessar a todos sempre), falta de apoio e acompanhamento dos responsáveis ou outros diversos fatores. No entanto, hoje tenho certeza de que os alunos que "entram no jogo" sempre se desenvolvem ainda mais.

\subsubsection{Os alunos têm muito a dizer: Cuidado! Cenas fortes para professores mais racionais}

Após realizar parte do conjunto de atividades que considerei como o momento em que atingi o ápice de uma ludificação ${ }^{62}$, pedi aos alunos que relatassem o que estávamos fazendo, expondo sua opinião a respeito daquelas aulas específicas. A grande maioria demonstrou estar adorando a nova estratégia com várias atividades em grupos, sempre muito dinâmicas, que eles nomearam de "brincadeiras":

Amei essa semana, foi uma das melhores semanas da aula de português. Adorei os desafios e meu grupo também é muito bom. Espero que fique até o fim do ano esse trabalho das Guildas. (AutorB16)

Essa semana foi incrivel sempre torcia para ser aula de português para fazer as missões da Guilda foi muito legal (AutorB1)

${ }^{62}$ Ainda vou apresentar algumas considerações sobre esse momento de estratégia em item posterior. 
Essa semana começamos com as guildas, achei muito divertida a experiência de trabalhar todo mundo junto, um ajudando ao outro numa equipe realmente.

Percebi que foi unanimidade, todos gostaram e estão gostando dessas dinâmicas que a senhora, professora de português, está nos apresentando. (...) (AutorB43)

O mais interessante é que, embora destaquem a alegria de ter aulas diferentes, não ficam numa superficialidade. Mostram que é possível aprender e que se estuda muito dessa forma.

Eu gostaria que todas as aulas fossem do mesmo jeito. Nesta semana estudamos bastante a lenda e, sendo assim, aprendi coisas que eu não conhecia e não sabia, foi muito "legal"! (AutorB5, grifos meus)

As aulas da semana passada, para mim, foram produtivas. Eu melhorei em expressar minha opinião e juntar várias ideias em uma só (...). (AutorA26 grifos meus)

E, talvez pelo diálogo e feedback constantes, eles estivessem começando a visualizar concretamente suas aprendizagens, como destacou AutorA26 nesse trecho e no que vem a seguir, quando diz: "Aprendi essa semana como fazer um texto opinativo e como deixalo apresentavel".

Além disso, pequenos detalhes que nos passam despercebidos no dia a dia da sala de aula, de repente, aparecem num comentário, destacando a sua importância. As novas tecnologias, por exemplo, são bastante interessantes e podem promover boas aprendizagens se bem utilizadas, mas as velhas tecnologias também cumprem bem o seu papel numa sala de aula que se propõe lúdica:

Gostei muito do que fizemos sexta, foi legal fazer o trabalho de um jeito diferente usando cartolina, cola e tesoura, instrumentos que geralmente não usamos. Aprendi essa semana como fazer um texto opinativo e como deixalo apresentavel. (AutorA26, grifo meu)

A necessidade de o aluno ser visto como indivíduo e não como parte da massa também sempre aparece. Isso, a meu ver, não pode mais ser ignorado pela escola. Não estamos formando massa. Estamos formando pessoas. Pessoas essas que precisam encontrar o olhar do outro e o desejo do outro para se tornarem humanas.

Eu achei super divertido as aulas dessa semana, pois a professora incentiva-me a não ter preguiça e seguir o fluxo corretamente. Aliás tenho que agradecer a ela imensamente. (...) Nós vizualizamos um pouco da realidade. E cada um pode expressar sua opinião, e eu adoro expressar minhas opiniões! (AutorA49, grifos meus)

Em um processo de confiança construída, os alunos também se expressaram sobre as provas formais do colégio logo na semana seguinte ao término das 
chamadas AE (Avaliações de Estudo). É muito forte a percepção negativa deles sobre todo o processo e sobre como os professores os veem. A escola realmente precisa rever essa questão porque o objetivo é a formação de cidadãos, mas parece que se deseja formar "concurseiros", isto é, pessoas prontas para enfrentar inúmeras batalhas de provas ao longo da vida. Será que é esse o real objetivo da escola? Talvez haja até um momento para isso no Ensino Médio, mas não no Fundamental.

As palavras medo, nervosismo, temor aparecem diretamente ou por meio de sinônimos quase que na unanimidade dos textos (elas serão sempre sublinhadas para que possamos ter a clara noção do sentimento dos alunos).

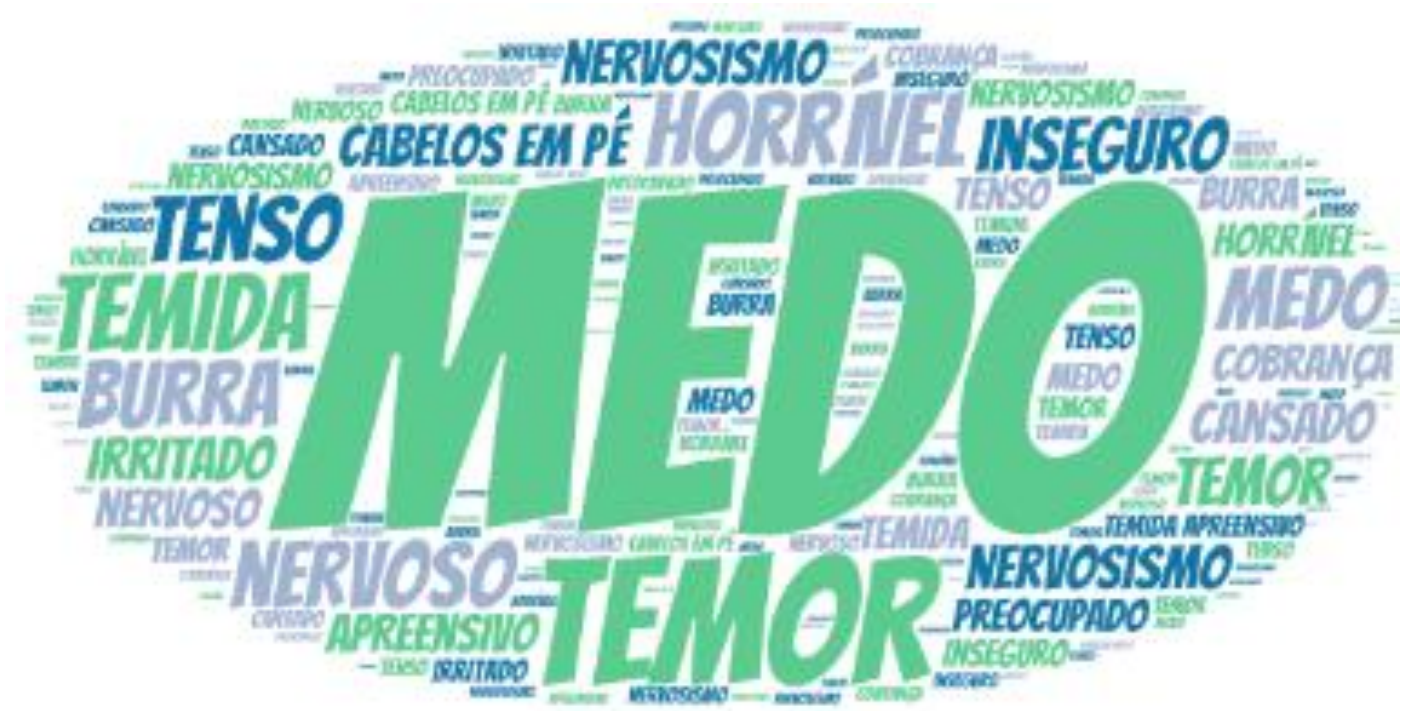

Figura 52:Nuvem de palavras e expressões com os sentimentos dos alunos em relação às provas. Relacionam-se tamanho de letra com a maior ou menor frequência de uso de termos diretos ou sinônimos.

Semana passada foi a tão temida pelos alunos semana de prova, que são as provas bimestrais. (AutorA44)

Certamente, essa semana é a de maior tensão para mim. Chego a casa pensando na prova do dia seguinte e mesmo que eu estude, fico nervosa. (AutorB43)

Na semana de provas fico muito nervosa e com medo, ás vezes choro. (...) $\underline{\text { Costumo }}$ rezar muito e estudar claro! (AutorA39)

A semana de AE foi muito corrida, nervosa e estressante. (...) As provas estavam todas difícies, mesmo eu temdo estudado muito. Todas elas tambem estavam grandes, fiz todas (ou quase todas) em pelo menos 70 minuto. (...) Em geral foi uma semana de deixar os cabelos em pé! (AutorA26) 
Além disso, a descrição do processo referente ao ato de esquecer o que se estudou mostra o quanto a aprendizagem ainda se mantém em um processo de aquisição de informações a serem guardadas na famosa conta bancária e a pressão e cobrança que eles mesmos se impõem geram os temidos "brancos", que parecem incompatíveis com um processo de construção lúdica de uma aprendizagem significativa.

Deveis em quando eu esqueço do que eu estudo, porque é muita coisa na minha cabeçinha, quando estou no ônibus da DE eu durmo para não esquecer as coisas, mais quando eu chego na escola eu acabo esquecendo de 2 ou 3 ai quando ta na hora da prova eu acabo esquecendo tudo por causa do meu medo de acabo errando tudo, eu começo a ficar nervosa começo a suar como se eu foçe lutar no ringue de luta e foçe acabar perdendo você me entende professora??... (AutorA11)

Quando eu me preparo para as semanas de AEs, eu estudo muito como um louco sempre na véspera para me lembrar de tudo durante a prova.

Eu sou bom aluno só que eu fico nervoso durante a prova, por isso, eu erro bobeira (...), eu me cobro muito para tirar acima de oito e meio e de tanta preucupação acabo errando o que sei. (AutorA21)

Me sinto horrivel! Porque apesar de ter estudado a matéria, eu me sinto inseguro e nervoso, isso é muito ruim para mim, porque na maioria das vezes me faz esquecer coisas importantes. (AutorA23)

Na semana de provas eu não parava nem sequer um minuto para descançar, era só estudo, estudo e sono. Todos os dias acordei as cinco e meia, escovei os dentes, fui ao banheiro, me vesti, peguei a mochila e desci para a van. Mas o nervosismo era tanto que eu ia estudando dentro da van. (...) Quando o professor chegava na sala para aplicar a prova eu sabia que era hora de eu mostrar tudo o que eu sabia, mas do mesmo jeito algumas coisas eu não lembrava e começava a ficar nervosa. (AutorB16)

Não senti medo de fazer as AEs, mas senti medo de me "dar um branco". E deu em algumas matérias.(...) Senti um pouco de medo de algum professor parar de falar comigo por uma nota 7. (AutorA49)

O sentimento de inferioridade também desponta quando eles têm liberdade para se expressar. Sentem-se burros e concretizam o medo na clássica imagem do "bicho papão".

Nossa só em escutar, ler, e ve esse nome eu penso em terror, sofrimento, muito trabalho, sem férias. (...) Agora sobre as AEs eu não mim sinto bem porque eu fico preucupada, mais nervosa e me sinto um pouco burra. (AutorA37)

(...) Quando entregam as provas pra mim fazer, fico cheio de medo achando que e um bicho do mal que vai fazer eu repeti (...) (AutorA10)

E a pressão perpassa da instituição escola, representada por um professor que tem uma opinião única sobre a falta de compromisso e interesse do aluno, 
para a instituição família e vice-versa. A criança vive isso em todas as instâncias e algumas sofrem com esse olhar "cobrador" e reprovador sem um preparo emocional para suportar. Além de reafirmar uma crença que se baseia no equívoco da proposta (“Acho que isso é normal.”):

Na semana de prova, fico muito apreensivo com o que vai cair. As vezes sei o assunto, mas na hora esqueço tudo. Acho que isso é normal. Quando se fala "prova", as pessoas ficam nervosas e dá um "branco" na hora. Os professores acham que não estudamos o suficiente, mas não é bem assim... (AutorA52)

Quando estou fazendo uma "AE" me sinto disconfortavel, (...) Realmente na hora da entrega de "AE" parece que toda turma fica triste, de repente todos se silenciam como se ninguém mais pudesse falar na vida, eu também fico com medo, por que sempre tenho a chance de tirar uma nota ruim, o ruim não é só a nota, é também a bronca dos pais depois de receberem a "AE". (AutorA50)

(...) Muita matéria, pouco tempo e a cobrança por notas excelentes tiram o sono de qualquer um, inclusive o meu. Os professores não perdoam, exigem tudo e mais alguma coisa. (AutorB34)

Na semana de AEs, me sinto preocupado, (...). Fico meio irritado com a situação porque não posso mexer no celular e etc. Mas sei que isso e preciso pois se for mau nas provas aí mesmo que não poderei fazer nada.

Geralmente fico mais nervoso para aquelas provas que realmente não sei a matéria (...). (AutorA36)

Em véspera de prova, muitas vezes eu fico nervoso. Em casa meus pais não deixam eu jogar futebol no campo e muito menos jogar video game. Foco no estudo! (...) Quando em um dia específico, não consigo compreender a matéria, fico muito tenso, nervoso e mais cansado. (AutorA42)

Na época de AE eu fico muito tenso, pois eu sempre penso que eu vou tirar nota baixa.Às vezes, quando eu tiro menor doque cinco meu pai briga muito comigo. Eu fico muito triste, mas quando eu tiro nota baixa eu fico com o espero que eu vou conseguir e vou recuperar a nota e graças á deus os professores desse ano e também nos anos anteriores botaram isso na minha cabeça ${ }^{63}$. Quando eu tiro nota alta eu começo comemora falar para um bando de gente sobre minha muito diferente quando eu tiro nota baixa eu fico de cabeça baixa, também não gosto de falar sobre minha nota em público e tambem evito falar com as pessoas. (AutorA46)

Apesar de todo sofrimento, às vezes aparece algo que renova a crença na Educação como a percepção acima do AutorA46: "mas quando eu tiro nota baixa eu fico com o espero [esperança] que eu vou conseguir e vou recuperar a nota e graças á deus os professores desse ano e também nos anos anteriores botaram isso na minha cabeça".

${ }^{63}$ A mãe desse aluno me procurou para saber como estava o filho no colégio. Ela informou que o pai era muito severo e não admitia nota baixa, chegando até a dar palmadas nele quando isso acontecia. 
Há também uma questão curiosa: a expectativa formada a partir de uma falta de noção verdadeira de situação de aprendizagem da criança (pela criança e pelos pais ou responsáveis). Isto é, por falta de um conhecimento maior das etapas da escola, do que se deve saber em cada fase e até do processo de estar inserida em um ano, mesmo que a criança não esteja apta a acompanhá-lo, gera expectativas que, muitas vezes, não são atingidas. Isso me parece claro no discurso da aluna AutorB18 que acabou sendo jubilada da instituição pela segunda reprovação. Ela estudou muito, teve um resultado ruim, mas, mesmo assim, achou a semana "dimais" [sic].

As semanas de aes foram Legais eu estudei muito mesmo Para sair um resuntado Ruim mas gostei de ter vindo quando fiz as aes me senti que ia tira uma nota mais do que isso mas naõ foi adorie essa semana foi dimais (AutorB18)

Outros alunos já se submeteram ao processo que lhes é imposto e acreditam que a não aprendizagem e os resultados ruins são exclusivamente culpa sua, fruto de uma menos-valia que se instala no aluno e que o responsabiliza por tudo de errado que lhe ocorre:

A semana de AE foi muito cansativa e estudiosa (tive que estudo muito) infelizmente minhas médias cairão e agora estou sofrendo as consequencias de minhas açoes (jogar video game e ver televisão mas aprendi a linção mesmo que nos outros bimestres a sua nota esteja boa não relaxe pelo contrário estude mais! (AutorB53)

Meus sentimentos momentos antes das provas. Me senti com medo e brancos, não havia mais tempo então resolvi começar. Depois que terminei a prova. Comecei a e lembrar do que deveria ter respondido mas não havia mais volta. Resultado. Pelo visto vou estudar muito mais para o quarto bimestre pois minha capacidade está muito abaixo de tirar uma nota rasuável em qualquer matéria. (AutorB6)

Aliás, nesse relato de AutorB6, fica explícito o quanto o nervosismo e o medo são prejudiciais. Ao terminar a prova, momento de grande tensão, tudo aquilo que sabia e durante a avaliação esquecera é, naturalmente, lembrado. Somado a esse esclarecimento para nós feito por AutorB6, há também quem, apesar de concordar com o processo porque já o incorporou como parte de sua jornada, enxergue não só problemas na formulação das questões, como também ratifique que a irritação e chateação, sentimentos opostos ao que se espera em uma escola lúdica, prejudicam a explanação da aprendizagem em avaliação. Verdade seja dita, vejo hoje que AutorB54 tem uma capacidade de se posicionar com firmeza, coragem e acertividade acima da média para a sua idade: 
As provas são o que os educadores usam para testar os nossos conhecimentos aprendidos em aula e o que revisamos em casa.

Eu penso que o método usado é eficaz, porém preocupante, pois muitos de nós, alunos ficamos irritados e chateados por não lembrar muito do que aprendemos, devido a falta de clareza em algumas perguntas presentes nas provas. (AutorB54)

Após a minha leitura de todas essas redações sobre a semana das AEs, em que os alunos descreveram seus medos e sofrimentos com riqueza de detalhes, dediquei um tempo de aula para conversar com eles sobre como aliviar um pouco esse estresse, o que poderia ser feito para diminuir a pressão e o medo. Para minha surpresa, no entanto, todos, sem exceção, foram afirmando que era necessário estar sempre com a matéria em dia, estudar diariamente o que tivesse sido dado em sala. Chamou-me atenção a ideia tão presente na fala deles e na nossa (de professores): "estudar e fixar o que foi dado", diferentemente de, por exemplo, reviver, rememorar ou ratificar as experiências realizadas, como processo de validação de uma aprendizagem. Percebo que para uma mudança real de paradigma são necessárias mudanças muito maiores do que simplesmente a construção de novas estratégias. O nosso discurso, por si só, já precisa mudar, mas o que validará isso, acima de tudo, será o nosso fazer.

Muito mais foi dito por eles nos diversos textos que tive a oportunidade e privilégio de ler nesses temas apresentados até aqui. Infelizmente, porém, não é possível no espaço desta tese expor e discutir todos eles. O que percebo cada vez mais forte é que a alegria tem de estar, de fato, presente na escola, e não o medo, o temor, o horror, muito menos o tédio.

\subsection{Trabalho em grupo: cria-se vínculo numa confiança desconfiada?}

De acordo com o Dicionário Houaiss da Língua Portuguesa, temos que grupo, nas duas acepções que interessam nesta pesquisa, é um

1. conjunto de pessoas ou coisas dispostas proximamente e formando um todo

1.1 reunião de várias pessoas

2. conjunto de pessoas ou coisas que têm características, traços, objetivos, interesses comuns

2.1 conjunto de seres ou coisas cujas características comuns são utilizadas para sua classificação 
Do mesmo dicionário, entendemos que equipe é o "conjunto de pessoas que se dedicam à realização de um mesmo trabalho" e, dentro dessa acepção é acrescentada a ideia referente ao desporto: "grupo de duas ou mais pessoas que, formando um conjunto solidário, participam de uma competição esportiva”.

O que se percebe é que sempre há termos que remetem ao todo, ao que é comum a todos. $\mathrm{E}$ as noções de interesses comuns e conjunto solidário se complementam na ideia maior. Essa definição, no entanto, não se concretiza na maioria dos trabalhos escolares em grupo. Seja porque alguns desses trabalhos são realizados mais para diminuir o número de correções (do professor) do que desenvolvimento de noções de conjunto, seja porque as propostas são passadas para os alunos sem que haja uma preocupação concreta com a aprendizagem das relações e interações entre os membros. Aliás, tais grupos, muitas vezes, são formados numa construção quase amadora, sem uma orientação para que constitua, de fato, grupo. Resultado: é muito comum ver um ou dois trabalharem e os outros serem "carregados" pelos alunos mais comprometidos. É muito comum também ver insatisfações, "dedo-duros", brigas, mas nós, professores, nem sempre sabemos lidar com essas questões. Na maoria das vezes, dizemos a eles que precisam aprender a trabalhar em grupo, que eles têm de aprender a respeitar a opinião do outro, como se essa aprendizagem fosse simples e natural, ou melhor, voltando à ideia equivocada do senso comum, quase "espontânea". Mas o que há de fato é que a escola não forma pessoas para viverem numa coletividade, para trabalharem em conjunto, para cooperarem com o outro e colaborarem no processo. $\mathrm{O}$ individualismo, a meritocracia, a mensuração constante e os rankings criados só corroboram para uma visão cada vez mais individualista e nada altruísta ou social.

$\mathrm{Na}$ segunda etapa da dinâmica da cor, realizada em grupos, isso ficou bastante claro para mim. Pude vê-los discutindo e querendo dar destaque à opinião pessoal sempre em detrimento da do outro.Essa observação também me mostrou que eles não têm a oportunidade, muitas vezes, de defender suas ideias apresentando argumentos, mas têm menos ainda a oportunidade de ouvir as ideias dos outros para refletir. Querem ganhar na força e no grito, e, nesse sentido, tive de fazer algumas intervenções, só que, nesse caso, eu não falava para todos, mas nos grupos em que isso se destacava. Aliás, eu, na parte que ainda agia como uma 
"professora tradicional", observei que essas aulas foram demasiadamente barulhentas. Os grupos reunidos, embora trabalhassem na escrita, eram muito ruidosos. Chamei a atenção de todos várias vezes a respeito do barulho ambiente, sem muito sucesso (baixavam o tom por alguns segundos e voltavam à fala muito alta, para não dizer gritos de vários, em seguida). Assistindo ao vídeo dessas aulas, pude notar claramente esse barulho constante, que chega a um nível altíssimo. A necessidade que têm de fazer barulho (bater na mesa com lápis, caneta, arrastar mesa, falar aos berros com o colega que está do lado) é muito grande. Observando, no entanto, tudo isso, como pesquisadora, tenho a sensação de que falta à escola proporcionar, de fato, no dia a dia dos alunos, muitas oportunidades da aprendizagem de estar no coletivo em atividades de sala, e não somente na hora e no espaço da Educação Física, por exemplo como afirma Ribeiro (2011), muito além da simples convivência entre colegas. Eles precisam aprender a trabalhar em conjunto, a repartir, a ouvir, a cooperar, a colaborar. $\mathrm{O}$ que seria uma sala de aula ativa, viva, lúdica, interessante?

O que é mais do que claro, por mais que teimemos em ignorar, é que trabalho em equipe não se faz unicamente com elementos cognitivos, intelectivos. A dimensão emocional, das relações socioafetivas se faz a todo tempo. Morgon (2013, p. 98) diz que "além dos elementos afetivos, da constituição do $e u$ pelo outro, cabe lembrar que o próprio avanço científico só acontece em comunidade, e não individualmente", o que ratifica mais uma vez a importância e necessidade do desenvolvimento de atividades em grupo na escola. A noção de coletividade, de trabalho em equipe, do ser em grupo se faz necessária, pois "fomentar essa ideia de construção comunitária na escola é contribuir para avanços no conhecimento" (MORGON, 2013, p. 98).

A.Mamede (2012) destaca como de máxima importância as situações educacionais criadas nos jogos e nas atividades lúdicas. Para o autor, por meio dessas situações, "a criança assimila e acomoda as realidades intelectuais, o que aponta para a importância do processo de ensino e aprendizagem". Para o autor, é muito importante salientar que não é o jogo ou a atividade lúdica em si que vai despertar ou instigar o processo da aprendizagem, mas sim e especialmente, a própria ação de jogar ou de participar das atividades, "a qual depende essencialmente da compreensão e assimilação das regras do jogo, além da 
imprescindível participação da criança na formulação e mesmo na alteração das regras formais do jogo.”(A. MAMEDE, 2012, p. 8) Ele conclui essa ideia, dizendo que "exatamente por comportar regras é que o jogo estimula a organização e a coordenação do pensamento que se inserem nos quadros de natureza lógica; quando essas regras são aceitas e praticadas, já está em ação um exercício de operação e de cooperação.”(2012, p. 8) Mas será que as regras costumam ser claras e inteligíveis?

É visível que vou mudando durante a execução da proposta, numa luta entre a professora antiga e a pesquisadora que a (me) liberta. É uma luta minha constante. Acredito que se não tivesse sido uma pesquisa-ação num caráter de autoestudo, se o observador fosse somente externo, não teria essa riqueza que estou enxergando, refletindo e aprendendo. Eu vivi toda essa experiência e por ela volto a Larrosa (2011, p.7), que explicita a subjetividade e a singularidade desse viver:

(..) o lugar da experiência é o sujeito ou, dito de outro modo, que a experiência é sempre subjetiva. Contudo, se trata de um sujeito que é capaz de deixar que algo lhe passe, quer dizer, que algo passe a suas palavras, a suas ideais, a seus sentimentos, a suas representações, etc. Trata-se, portanto, de um sujeito aberto, sensível, vulnerável ex/posto. Por outro lado, o "principio da subjetividade" supõe também que não há experiência em geral, que não há experiência de ninguém, que a experiência é sempre experiência de alguém ou, dito de outro modo, que a experiência é, para cada um, a sua, que cada um faz ou padece sua própria experiência, e isso de um modo único, singular, particular, próprio.

E já me preparo para uma nova construção para os anos seguintes, para as turmas seguintes.

Leio agora como uma de minhas falhas nessa última atividade comentada o fato de não ter aproveitado os textos coletivos produzidos para trabalhar as diversas vozes aparentes dos próprios alunos. Alguns textos foram apenas a junção das opiniões individuais colocadas misturadas, sem uma "costura". Em outros grupos ficou explícito que para eles uma produção coletiva seria sinônimo de opinião única. Poucos conseguiram costurar ideias distintas mostrando um lado e outro de uma mesma cor, sem atrito. Talvez, na verdade, o erro maior tenha sido meu por não ter atinado para o fato de que considerações tão pessoais não pudessem se adequar a uma construção coletiva. Principalmente por ter sido essa a primeira construção textual em grupo. Não vi, no momento, o que hoje se faz evidente: o coletivo anularia as individualidades subjetivas por mais que os alunos tivessem maturidade e conseguissem lidar com diplomacia na construção do 
conjunto. É nesse sentido que hoje entendo a importância da autoavaliação constante do professor. É necessário parar e ver com olhos investigativos o que estou propondo, onde quero chegar, quais os objetivos da proposta; mas também é preciso avaliar sempre o processo em contrução: o que se construiu de fato na prática com o que se propôs, que ajustes ou mudanças devem ser feitos.

Tive retorno da opinião dos alunos acerca das atividades em grupo por dois meios: os cadernos de opinião, em que relataram e opinaram sobre as atividades que estavámos realizando e na questão aberta (subjetiva) da primeira (auto)avaliação, no fim do terceiro bimestre letivo.

A partir das opiniões expressas sobre as atividades, pude constatar que vinte e seis alunos gostaram da atividade coletiva de produção de texto. Eles percebem que estão ali para produzir, para aprender, para fazer na prática:

trabalhar em Grupo é Bom mas naõ é só, ficar falando e naõ fazer nada (AutorB18 - escritura)

Além disso, conseguem valorizar o papel do outro que é seu par (colega) na sua aprendizagem

acho Bom fazer as coisas em grupo porque tem pessou oara ajudar as outras (AutorB18 - reescritura)

Alguns têm maturidade para entender a importância de trabalhar em grupo:

Eu gostei! O porque de eu ter gostado foi porque a pessoa tem que a prende a trabalhar em equipe e também aprende a ouvir e a falar. (AutorA37)

Outro ponto importante dessas críticas e da confiança que depositaram em mim foi a exposição, por exemplo, da dificuldade de lidar com as diferenças de gênero e de conduta no que diz respeito ao compromisso de cada um com a missão a ser cumprida. No primeiro caso, suas subjetividades e individualidades, marcadas, muitas vezes nessa idade, pelos conhecidos clubes "da Luluzinha" e "do Bolinha" poderia ser omitida por alguma vergonha natural de se expor:

Foi muito bom mas podia, colocar meninas com meninas e meninos com meninos aí todo iria ler o texto do outro e cada um ia fazer o de todo mundo. (AutorB45)

No segundo caso, a reclamação da exploração de colegas que não produzem a contento e se escoram nos outros aparece sem que quem escreve tenha medo de ser exposto e, depois, achacado pelos colegas que poderiam ser advertidos por $\operatorname{mim}$.

Eu gostei muito de tudo tirando à parte que algumas pensavam que o trabalho duro é para o que tem q.i mais alto, mas a junção de ideias foi difícil mais eu gostei. Eu adorei. (AutorA21) 
Aliás, váriasvezes apareceram reclamações sobre colegas não participarem da produção textual coletiva ou atrapalharem a atividade. A lacuna da escola que não desenvolve, de fato como parte inerente ao seu trabalho, a coletividade e a responsabilidade social num processo colaborativo e cooperativo está explícita. Alguns reclamavam da dificuldade de um lidar com a opinião do outro:

Aquele trabalho em grupo não achei muito legal pelo fato de algumas pessoas não estarem trabalhando, por isso não gostei do trabalho. (AutorB1)

Eu não gostei de fazer o trabalho em grupo. É todo mundo brigando por causa das palavras para serem colocadas no texto. Alguns até ficaram de mal uns com os outros. (AutorA23, grifos meus)

Eu acho chato ter que juntar todas as opiniões, porque eu achei complicado e não entendi o porque de ter que fazer isso, também tinha gente que não queria fazer nada e só conversava. (AutorA32, grifo meu)

O trabalho em grupo também pareceu inibir alguns no início que, embora confirmando a timidez, tenham gostado e aproveitado:

Achei a ideia muito legal em grupo, mas me senti um pouco mais fechada, pois não sabia se as meninas iriam gostar da minha ideia mas no final juntando tudo ficou legal. (AutorA35)

Mas o desenvolvimento da prática coletiva, apesar de ter falhas minhas, como já apontei, também teve seu êxito, isto é, a "semente" da coletividade também foi lançada...

A parte de fazer em grupo foi bem interessante, porque tive a oportunidade de expor e dividir minhas ideias e reunir o trabalho de todos os integrantes com o propósito de formar um bom texto opinativo. (AutorB43, grifo meu)

Gostei do trabalho em grupo, pois focava em união (AutorA50, grifo meu)

Com essa dinâmica conseguimos saber um pouco mais o que os nossos colegas pensam e escrevem. Juntamos nossos conhecimentos e ideias.

Ao produzir um texto em grupo, com todas as opiniões misturadas, discutimos, $e$ muito, os ponto principais de cada um dos textos para chegarmos em um acordo do que escrever no final, e isso foi ótimo. (AutorB34, grifos meus)

Nove alunos disseram não ter gostado das atividades. $\mathrm{O}$ argumento mais utilizado foi a dificuldade de um ouvir a opinião do outro, isto é, fica bem caracterizada a dificuldade de estar em um grupo cujos membros apresentam opiniões divergentes. Fica também aparente, no entanto, a ideia de medo de se expor, de sair da zona de conforto:

não queria fazer em grupo, e sim fazer um sozinha ou em dupla. (AutorB54) 
Eu não gostei muito do trabalho em grupo porque tiveram duas pessoas que nãa estavam concordando com os outros, então resolveram sair do grupo, isso foi ruim porque a gente ficou sem idéia falar. (AutorA46, grifos meus)

Prefiro fazer sozinho, porque em grupo é trabalhoso e demora. (AutorA26)

O trabalho em grupo, achei muito chato Pois todos tinham que concordar com a opinião do outro (AutorA10, grifo meu)

Texto coletivo não é sinônimo de texto com opinião única ou unânime. Muitos não perceberam, ou melhor, não entenderam que poderiam mostrar, ao mesmo tempo, o que uns e outros pensavam sobre a cor, apresentando as opiniões distintas e até contrapondo e confrontando as diferenças. Outros tiveram essa percepção da dificuldade de unir ideias de várias pessoas, mas isso não os intimidou:

Achei mais complicado unir o que pensamos de nossas cores, mas no final conseguimos um bom texto. (AutorB6)

(...) foi difícil juntar as ideias, porém deu certo. (AutorA42)

O que pude constatar, ao final das diversas atividades que propus em grupo, é que é necessário um trabalho de formação social e de valores, na prática, muito maior do que sabemos desenvolver. Grupo não é uma simples junção de cabeças, de intelectos, para resolverem um problema. Grupo, na Educação Básica, é a junção de corpos, de sentimentos e emoções, de diferentes credos e valores, de distintas condutas e princípios como alunos, de variados desejos e sonhos e, dependendo da idade desses alunos e do tamanho da proposta (principalmente aquelas que ultrapassam as paredes da sala de aula), pode ser também a junção de diferentes famílias.

\subsection{Do grupo à guilda: Sobre o clímax da proposta lúdica - uma estratégia na qual se pretendeu construir uma aprendizagem colaborativa}

As atividades nomeadas "Missões Lúdicas com Enredo" foram consideradas como uma tentativa, em partes, satisfatória de uma estratégia lúdica em sua essência porque, em sua composição e articulação, incorporei elementos e estratégias de jogos na sala de aula, isto é, em um ambiente e contexto que não eram de jogos. 
Primeiramente criei as guildas, como relatado no capítulo 3, já com a ideia de associação que agrupa pessoas com interesses comuns se formando na cabecinha deles a partir da leitura do livro paradidático já mencionado. Em seguida, coloquei em ação a narrativa que elaborei e que levou os alunos a se envolverem nas atividades e a se interessarem por elas como se estivessem realizando missões dentro de um jogo. Havia regras bem estabelecidas, com tempo e pontuação determinados para cada etapa. Dou destaque a essas questões porque estava muito interessada em desenvolver uma ação de grupo, ou mellhor, um sentimento de guilda que promovesse uma atitude de cooperação e de colaboração entre seus membros, para que cada "jogador" fizesse a sua parte, mas também enxergasse que o outro precisava concorrer (no sentido de correr junto) com ele, juntando forças a fim de conseguirem atingir os objetivos traçados. Eu, como orientadora, estava ali presente todo o tempo para lhes dar um feedback sobre o que estavam fazendo a fim de que tivessem tempo de escolher novos caminhos ou estratégias a seguir. E um quadro de pontuação, individual e das guildas, para cada etapa também se criou para que eles tivessem noção de seus passos.

É importante deixar claro que a estratégia lúdica que realizei, por mais que fosse construída com atividades também individuais, teve em sua base, na sala de aula, a estrutura de grupo, de equipe, de guilda. Dessa forma, parte do que vivenciei e experimentei com os alunos e pude observar esteve intimamente ligado à questão que considero ainda muito delicada ao processo de ensino e aprendizagem: o individualismo versus a necessidade de aprender e viver valores sociais. A passagem do passivo para o ativo e do individual para o coletivo são processos difíceis e, para alguns, até dolorosos.

Apesar de todo o envolvimento e interesse da maioria, sempre há aqueles que, embora já ativos dentro de sua visão, pouco realizavam na visão de outros colegas. E, com o passar das aulas, que exigiam uma ação constante para cumprir as missões, encontrei os dois polos opostos comuns à escola tradicional: alguns acabavam, de fato, se acomodando um pouco, escorando-se em uma cômoda visão de grupo ${ }^{64}$; outros tomavam para si determinadas funções e se intitulavam "donos", "chefes" do grupo, e queriam mandar nos outros. Na verdade, o

${ }^{64}$ Um ou dois trabalham e o os outros são "carregados". 
individualismo, nesses dois opostos, sempre aparecia. Então, eu usava as constantes reclamações de um e de outro que apontava para o fato de que determinado(s) membro(s) não estava(m) participando como os demais da guilda para dialogar com o grupo e tentar ajudá-los a enxergar o real problema (por exemplo, se a não participação de um colega vinha da falta de interesse, se era em decorrência da falta de entrosamento, se era porque algum colega se considerava chefe e queria que sua vontade sobressaísse sem dar voz aos demais etc.).

Inspirava-me em Fortuna (2000, p. 4) que explica que "quando sentimentos agressivos são expressos, por meio da brincadeira, de forma aceitável, não só o processo civilizatório está em curso, com a sujeição do indivíduo a regras socialmente construídas, como a capacidade de representação é ampliada".Esse diálogo e a orientação constantes com a minha presença durante todo o processo me fizeram perceber que "a preocupação com a mediação e o contexto da ludicidade" (FORTUNA, 2000, p. 4) são fundamentais para a sala de aula atual. Infelizmente, porém, a escola ainda se coloca, na maioria das vezes, alheia a essas questões e se exime de atuar.

$\mathrm{Na}$ primeira missãoem que as guildas precisavam encontrar as imagens para montar o quebra-cabeças com o texto que receberam repleto de lacunas, por exemplo, houve situações interessantes de colaboração entre as guildas, quando peças repetidas eram encontradas pelo mesmo grupo e passadas ao próximo, mas também houve alunos que tentaram prejudicar seus colegas, escondendo as peças que já possuíam para atrasar os demais. Essa situação permitiu-nos discutir questões referentes aos valores e à ética, presentes no livro paradidático do bimestre. Creio que, somente em situações de vivências ou exemplos concretos, esses temas podem ser abordados em sala. Caso contrário, não passarão de teorias e sermões incompreendidos pelos mais jovens.

Apesar dos problemas que surgiam com as adapatações a um novo formato de sala de aula, todas as atividades desse conjunto, sem exceção, criaram um grande envolvimento por parte dos alunos que foi percebido pelos meus colegas professores, pois eles esperavam ansiosos as aulas seguintes de Língua Portuguesa. Considero esse trabalho de desenvolvimento da capacidade de lidar com o outro como ele é, e, mais ainda, da capacidade de lidar com as próprias expectativas e exigências de si mesmo bastante importante na escola que temos 
hoje em pleno século XXI, que se diz para todos. Macedo (2008, p. 20) afirma que o professor, como mestre, não ensina simplesmente um conteúdo escolar, ele ensina "um modo de administrar as coisas, uma posição diante do mundo, transmite valores”. E isso não se faz na teoria. São necessárias situações práticas e concretas para que o aluno as observe, as vivencie, as experimente e as perceba. Só assim ele terá condições para (re)avaliar suas ações e confrontar com as ações dos colegas e do professor. É Macedo quem, também, apresenta uma oposição clara entre a escola seletiva e a escola que se quer para todos. $\mathrm{O}$ autor afirma que ações como

desenvolver disciplina de estudo, saber prestar atenção, concentrar-se, saber tomar notas, dominar diferentes procedimentos de leitura e escrita conforme os objetivos e segundo as características do material analisado, ouvir as aulas, fazer as lições de casa, estudar para as provas, saber debater um tema em sala de aula, compartilhar tomadas de decisão, enfrentar situações-problema, ser tolerante, respeitoso, amoroso com os colegas, professores e objetos de estudo etc., são procedimentos ou atitudes que o aluno deve desenvolver, mesmo que pouco a pouco, em favor de seu sucesso escolar. (MACEDO, 2008 p. 14)

Mas ele mesmo questiona: "Onde, quando, com quem, como aprender esses procedimentos ou formas de relação?” E “(...) em que tempo e lugar os alunos podem aprendê-los?” (MACEDO, 2008 p. 15) Não se pode esperar que o aluno tenha tudo isso como pré-requisito em nenhum ano da escola para todos, nem que traga de casa, como muitas vezes o senso comum pressupõe que deva existir, como se houvesse uma aprendizagem "espontânea", já afirmei isso outras vezes.Ao contrário,isso se faz numa construção diária, em todos os anos, em todas as disciplinas, com todos os professores em sua heterogeneidade no modo de ser e na matéria específica que lecionam.

Alguns alunos, apesar de gostarem da nova estratégia, apontavam, nesse caso, com um senso crítico claro e objetivo, problemas que devem ser vistos e trabalhados para o bom desenvolvimento desse tipo de proposta ${ }^{65}$. Destaca-se, principalmente, a relação equânime de realização dos trabalhos em grupo pelos membros e o respeito mútuo. A figura abaixo concentra e resume trechos das falas dos alunos destacadas em seus próprios textos, alguns deles, transcritos em seguida.

${ }^{65}$ Os trechos destacados abaixo foram escritos pelos alunos na folha de (Auto)avaliação do terceiro bimestre. O modelo dessa proposta está disponível no Anexo 3, para consulta. 


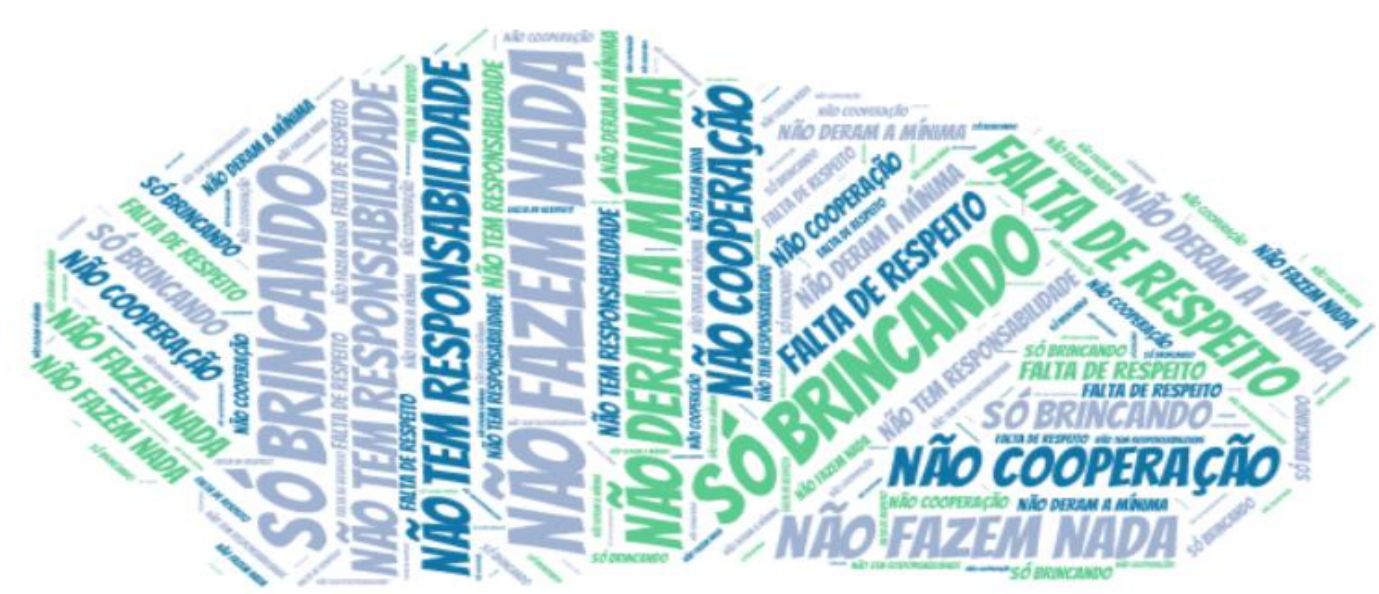

Figura 53:Nuvem de expressões negativas que se destacam nas falas dos alunos sobre a atuação dos colegas nas guildas.

Achei muito interessante a nova dinâmica, mas a minha guilda não deu muito certo, pois há 5 integrantes, mas só 3 que fazem as atividades e que estão empenhados. Adorei todas as atividades. (AutorA24, grifo meu)

Eu gostei muito da aula do terceiro bimestre pos a gente fez trabalho em grupos e também a gente fez avaliações em grupos. Infelizmente teve duas pessoas da minha gilda não fizeram nada. (AutorA46, grifo meu)

As aulas foram muito legais, divertidas, mais vivas e dão vontade de aprender está quase tudo perfeito na aula tirando o fato que eu gostaria que minha guilda trabalhace mais e não ficasse só brincando. (AutorB27, grifo meu)

A aula de Língua Portuguesa está sendo muito legal nesse bimestre. Super dinâmica, interativa com os alunos. Positivamente foi os alunos interagindo bastante. Negativos, Alguns alunos das guildas não tem responsabilidade, gritaria nas salas. (AutorB33, grifo meu)

Eu gostei bastante e o jeito como a aula foi dada, foi com atividades criativas $e$ diferentes. E o que eu não gostei foi como os meus parceiros não contribuíram e fez tudo de qualquer jeito, não deram nenhuma mínima, com algumas exceções. (AutorB4, grifo meu)

Nesse bimestre nós tivemos uma dinâmica interessante, (...) Poucos fatos me deixaram triste e foram negativos, como alguns alunos não cooperando (...) (AutorA44, grifo meu)

Adorei esse bimestre, pois teve trabalho em grupo com os outros colegas oque é bom e divertido. (...) e achei negativo a minha falta de respeito com meus colegas e a falta de respeito deles comigo. (AutorB1, grifo meu)

As aulas são ma-ra-vi-lho-sas eu amo de verdade, agora de negativo é quando alguma pessoa da guilda ou não faz ou esquece ai a guilda toda perdi ponto. (AutorA13, grifo meu)

Não gostei de tentar fazer os exercícios com todos e algumas pessoas, em vez de ajudar, atrapalham. (AutorB34, grifo meu) 
Esse bimestre foi muito bom pois a minha guilda foi muito boa só que tinha uma pessoa que não tinha comprometimento. (AutorB19, sobre o $4^{\circ}$ bimestre, grifo meu)

Achei muito mais legal do que as outras aulas, pois estamos aprendendo e brincando ao mesmo tempo e ainda gostei mais que estou me dando bem com a professora Tatiane. $O$ ruim é que tem muitas pessoas que se acham melhores do que as outras. (AutorA35, grifo meu)

Essa aluna última aluna citada (AutorA35), desde o início do ano, tinha certa implicância comigo porque eu costuma chamar sua atenção pelo comportamento muito agitado e desinteressado em todas as aulas. Em outra opinião, já sobre o $4^{\circ}$ bimestre, sua visão volta a ser de cansaço. Ela tinha muita dificuldade de se envolver com responsabilidade:

A minha opinião é que as aulas estão muito cansativas e repetitivas, nós sempre fazemos as mesmas coisas, já está chato. E nós estamos escrevendo muito! Estou quaze com um calo no dedo de tanto escrever.

No final do ano, acabou reprovada em outras matérias que não LP, apesar de todos os professores terem a certeza de que o problema dela não era incapacidade, mas o que denominaram "certa preguiça". Em 2015, no término do primeiro mês de aula, AutorA35 me encontrou no corredor do sexto ano, veio correndo me abraçar e me dizer que queria que eu voltasse a ser a professora dela. Então eu falei sorrindo que, se isso acontecesse, ela teria de produzir muito, escrever sempre muito. Ela parou, me olhou e disse: "Professora, eu não soube aproveitar."

Dando continuidade às falas dos alunos, se para uns o incômodo com a disputa/competição ultrapassou a guilda, para outros foi extremamente positiva.

Visão Negativa:

Gostei (...) como a professora ensinou eu gostei como ela formou os grupos e as suas atividades mas não gostei das copetições entre guildas. (AutorA38)

Este bimestre foi muito legal, principalmente por causa do trabalho das guildas, das brincadeiras e do conteúdo, porém o chato (...) foi a baderna na hora de montar as guildas, das brigas entre as guildas (...) (AutorA51)

Minha opinião é que houve muitas coisas positivas como terminar o trabalhos dos livros. E negativas foi não ganhar nada. (AutorB30)

Visão Positiva:

Fazer que fique as guildas mais competitiva (AutorB40)

A crítica da aluna AutorB43 me conduz a sentir uma necessidade maior de observação dessa estratégia para tentar equalizar questões que surjam ao longo do 
processo e que têm de ser solucionadas pelo professor orientador. Inicialmente com uma visão positiva da estratégia:

Essa nova maneira de ensinar aos alunos sem dar aquele tipo de aula monótona foi muito interessante. (...) estou adorando a experiência. Portanto não tiveram pontos negativos. As guildas fizeram com que aprendêssemos a trabalhar em grupo.

No quarto bimestre, já não permaneceu da mesma forma e o problema maior me pareceu ser a organização das guildas.

Esse bimestre não foi dos melhores em relação à Língua Portuguesa. Não gostei da guilda em que fiquei, e confesso que não fiquei muito animada depois de algumas atividades.

Foi nesse processo de construção do sentimento de grupo que uma equipe se destacou para mim logo no início das atividades com guildas. Os alunos AutorB34, AutorB54, AutorB6 e AutorB41 eram alunos de médio-bom a excelente rendimento escolar individual. No entanto, eles não conseguiram, apesar de cumprirem praticamente todas as tarefas, ter um bom rendimento enquanto guilda. Eles eram muito responsáveis e empenhados individualmente. Mas na hora de realizarem as atividades em grupo, não conseguiam coordenar as etapas, organizar-se, nem coordenar as opiniões divergentes.

Conversando com eles durante a terceira etapa da atividade com adjetivos, disseram-me que não conseguiam aceitar as opiniões diferentes de cada um. Enquanto todas as guildas já estavam terminando a tarefa, eu tive de lhes dar uma nova folha, pois não estavam seguindo a regra de colocar os adjetivos um de cada vez, rodando a folha entre eles, como pedi. Como não haviam conseguido fazer isso, um dos membros completou uma linha inteira vertical com todos os seus adjetivos e passou adiante, como quem diz: "eu já fiz a minha parte, agora vocês têm de fazer a de vocês".

Essa falta de capacidade de realizar as missões em equipe apareceu em seus textos de opinião sobre as aulas e em nossa conversa, pois foi com eles que fiz o único grupo focal da pesquisa. Era necessário entender o que estava acontecendo muito além de minha disciplina específica. Winnicott $(1999$, p. 49) trata dessa questão, afirmando que

todo e qualquer professor precisa saber quando está lidando não com seu assunto específico, mas com psicoterapia, ou seja, complementando tarefas incompletas que representam falha parental relativa ou absoluta. A tarefa a que me refiro é fornecer um suporte ao ego onde ele é necessário. O oposto é rir dos fracassos da criança, especialmente quando eles representam o medo de seguir adiante. (grifo do autor) 
Eu os escolhi, então, porque precisava entender como que quatro alunos bastante aplicados não conseguiam ter sucesso nas atividades em grupo. E isso ficou claro para mim durante a conversa. Todos eram, praticamente, filhos únicos, porque os que tinham irmãos apresentavam uma diferença entre eles de mais de dez anos, uns até já casados, morando em outra casa. A individualidade estava marcada também nos quartos em suas casas: cada um tinha o seu próprio quarto sem precisar dividir com ninguém. Os quatro não tinham o costume de brincar na rua, por causa do perigo e passavam muitos finais de semana em casa, jogando videogame, vendo televisão ou estudando, apenas com os responsáveis (pessoas, então, mais velhas) presentes $^{66}$. Talvez por isso todos quisessem que a sua vontade prevalecesse e não conseguiam perceber que, num trabalho em equipe, cada um tem de ceder um pouco. Queriam realizar tudo ao seu jeito e por isso preferiam fazer sozinhos a ter de aceitar o jeito como o outro participava.

A oportunidade de opinar com frequência também lhes deu a abertura de expor com liberdade os seus sentimentos e me permitiu entender a situação mais a fundo. AutorB6 na semana anterior ao acontecido tinha relatado estar adorando as novas aulas:

As aulas dessa semana foram maravilhosas. Eu tive a oportunidade de escrever textos: visuais e tradicionais, tive a oportunidade de escrever também belas poesias. (...) Adorei as atividades sobre poesias desta semana porque além de expandir meus conhecimento e criatividade me trouxeram prazer em apreciar a arte das palavras.

Ela, porém, expôs detalhadamente, na semana seguinte, seus sentimentos sobre a experiência. Agora o que vivia era algo bastante negativo e sofrido (os grifos são meus):

As aulas dessa semana foram as piores do ano inteirinho! Achei que nesses trabalhos em grupo deveríamos nos divertir, mas aconteceu o contrário. Agora neste exato momento estou com um pouco de raiva. Porque eu e [AutorB54] saimos chorando do colégio, porque ainda não temos nem cinco pontos! Então significa que eu a "tola" fiz todos os trabalhos por nada"!?!?". Agora sinceramente estou gostando muito menos de Português.

Tudo bem que tive a oportunidade de fazer textos, cartazes, gincanas e tudo mais. Mas em nenhuma dessas atividades ganhamos ponto.

Tudo bem que o importante não é ganhar mais fomos humilhados: riram e debocharam de nós nas redes sociais, (chat privado) ou em nossa frente mesmo. * Me desculpe se fui muito "melodramática" neste trecho ou desde o começo mas tenho que desabafar, ser sincera, e franca. *

${ }^{66}$ Aliás, esses alunos tinham dito na dinâmica com o substantivo nunca terem jogado Adedanha, o que pode ratificar a pouca ou nenhuma familiaridade com essa atividade lúdica coletiva que, pelo seu processo de jogar, precisa desenvolver no jogador a capacidade de se relacionar em grupo. 
Bom voltando ao que interessa, aprendi que em cada cantinho deste imenso país há sempre um ser lendário esperando para ser explorado, e contar sua história para nós.

Peço desculpas se escrevi algo que não tenha gostado mas é a minha opinião sobre esta semana. Mas vou olhar e seguir em frente quem sabe não recuperaremos?

Lendo esse relato, não consigo me perguntar outra coisa senão quanto de errado nós, professores, fazemos na sala de aula. A quantos sofrimentos submetemos nossos alunos? Nesse texto "melodramático", temos a síntese do que, muitas vezes, fazemos com os alunos em nossa prática docente. Alimentando uma concorrência intelectual exacerbada, depreciamos os que não atingem um patamar esperado ao enaltecermos aqueles que se destacam intelectualmente. $\mathrm{Na}$ verdade, estamos (até inconscientemente) sempre dando "munição" para que haja competição, em busca de um sucesso racional e individual, com base no que chamamos de esforço pessoal. Esquecemos, no entanto, que nem sempre os que não atingem esse sucesso deixam de se esforçar. Ao contrário. Num modelo ainda com viés seletivo, a noção de menos-valia é o produto final para um grande número de crianças que passam pela escola sem que a escola passe por elas.

Outros dois membros da mesma guilda demonstraram a questão de forma menos incisiva, mas deu para perceber a insatisfação deles também. AutorB34, aluno de excelentes notas em avaliações formais individuais e uma ótima produção textual, demonstrou a sua dificuldade de lidar com o sentimento de grupo (grifos meus):

Esta semana não foi das melhores.

Na segunda-feira, tivemos que procurar, pela sala de aula, as figuras para completar o texto "Mapa do Território Brasilis". Meu grupo (guilda) não conseguiu achar todas as figuras e não ganhamos pontos.

Na terça-feira, fizemos um outro trabalho sobre folclore. Tivemos que descobrir as lendas pelas características e desenhá-las. Os três mais rápidos ganhavam e os melhores desenhos, também. Não ganhamos nada.

Sexta-feira, a atividade foi descobrir a lenda da outra guilda e tentar não ser descoberto.

Pesquisei, imprimi várias lendas e, mais uma vez, meu esforço não deu em nada. Meu grupo continua com zero ponto.

A verdade é que estou gostando muito das atividades porém, não estou gostando nada de ser em grupo. Eu me interesso e os outros não estão nem um pouco preocupados. Parece até que não se importam com as atividades.

Não sei se meu grupo é que está ruim ou se os outros é que estão muito bons.

Só então percebi que eu pensava estar desenvolvendo uma aprendizagem utilizando a cooperação, a interação, o feedback, o engajamento, o altruísmo. No entanto, estava esbarrando em questões referentes ao emocional dos alunos, que 
ignoramos, quase que plenamente, no dia a dia da sala de aula. AutorB34 expõe, com precisão, o erro no qual a estratégia estava caindo com a repetição da ideia de derrota presente ao final de quase todos os seus parágrafos: "Não ganhamos ponto.”; “Não ganhamos nada.”; “(...) mais uma vez, meu esforço não deu em nada. Meu grupo continua com zero ponto.”. Estava explícito ali naquele desabafo uma intenção motivacional de engajamento ligada ao ganho de pontos e ao ranqueamento. E o pior, eu estava repetindo o que prevalece na escola desde a sua criação: só interessa o produto final bem feito e correto. Não valem as tentativas, muito menos os erros. Se lúdico, como conceituado no capítulo 2 , é tudo aquilo que provoca, desafia, encoraja (a realizar) uma ação por parte de quem foi instigado por algo ou alguém, o processo tem de ser valorizado em todas as suas etapas, talvez mais até do que o resultado final.

Ao somar essas expressões de AutorB34 destacadas à fala inicial do AutorB6: "deveríamos nos divertir, mas aconteceu o contrário" e "Porque eu e [AutorB54] saimos chorando do colégio, porque ainda não temos nem cinco pontos! Então significa que eu a "tola" fiz todos os trabalhos por nada'!?!?'.", posso concluir que a estratégia por mim criada, apesar de ter gerado inúmeras aprendizagens concretas e muito interesse por parte de diversos alunos (isso está comprovado, por exemplo, nas demais opiniões expostas no item que trata dos textos de opinião), falhou ao ter a pontuação e o ranqueamento como elementos. Sinceramente, ainda não sei - e nem sei se conseguirei saber - se fui eu que dei à pontuação um valor tal que a elevou em detrimento de outros elementos, fazendo com que os alunos a colocassem como fim e não como meio, ou se os próprios alunos - tão acostumados a serem ranqueados sempre e a serem avaliados por nota - deram-lhe um destaque e eu não soube contornar essa situação. Uma outra hipótese que posso levantar é o fato de a instituição ter muito acentuada essa característica de ranqueamento (Aluno 01... Aluno Coronel etc.), que gera um alto grau de competitividade pelo status, principalmente entre os alunos concursados.

Além dessas questões, AutorB34 deixa bastante explícita a questão do individualismo com uma leitura de que o erro, o problema é sempre do outro, que não faz o que deveria ser feito e, por isso, o grupo não conquista o espaço que o indivíduo (se estivesse numa disputa isolada) teria êxito. 
Aliás, posso também ratificar isso com a (auto)avaliação feita sobre a construção do teatro de fantoches. ${ }^{67}$ Comparando as respostas de cada membro de uma mesma guilda, é possível perceber como os colegas se contradizem. Eles não se definem ao certo quem escolheu a lenda para a encenação, se todos em um acordo, se apenas um colega, ou se o próprio que responde.

O mesmo acontece com a produção dos fantoches (os bonecos em si). Às vezes, na mesma guilda, um dizia que havia feito tudo, o outro dizia que cada um tinha feito o seu. O mais curioso, a meu ver, foi que, em muitas situações a culpa por uma falta ou erro pareceu ser sempre do outro. Dos doze alunos que assumiram não ter feito nada do trabalho, dez escolheram a opção "Eu não fiz nada porque meus colegas não me disseram o que era para fazer." para representar a sua situação. Havia, no entanto, outras duas opções que poderiam ter sido marcadas para esse caso: "Eu não fiz nada porque não tive interesse." ou “ Eu não perguntei aos meus colegas o que era para fazer, então não fiz nada.”. Apenas um marcou esta última opção, assumindo a sua falta e o outro desse grupo de doze escreveu na opção "Outros" que "não sabia o que era para fazer", mas continuou também não assumindo diretamente não ter tomado a iniciativa de procurar se informar, ao menos. Afinal, de quem é a culpa? E há culpados?

Retomando a questão levantada pelos quatro alunos, o relato de AutorB54, além de ratificar o erro a que o caminhar da estratégia incorreu - a pontuação, o ganhar destaque na turma pelas conquistas quantitativas -, demonstrou a não valorização, por nós, professores, e por eles, alunos, das suas conquistas qualitativas na aprendizagem.

Na semana nós fizemos vários trabalhos como pesquisar lendas que ninguém conhece. Apareceram várias lendas que eu não sabia que existia, como a lenda do açaí, do pai da floresta e mais.

A guilda, pelo que observei, se esforçou cada vez mais para ganhar pontos. Nossa guilda, fez como todas as outras guildas, o Mapa brasílis, os trabalhos individuais e a pesquisa das lendas desconhecidas, e nos decepcionamos em todas.

Acho que deveria ter segundas rodadas para dar uma segunda chance para guildas quando ouver dois tempos. (grifos meus)

Nesse depoimento ficam bem explícitas as aprendizagens: “fizemos vários trabalhos como pesquisar lendas que ninguém conhece. Apareceram várias lendas que eu não sabia que existia”. No entanto, o que se destaca como importante para

\footnotetext{
${ }^{67}$ Esta foi a última atividade do terceiro bimestre, que foi apresentada no período letivo do quarto, como já expliquei nos capítulos 4 e 5 .
} 
a aluna, como já mencionado anteriormente, foi que a guilda "se esforçou cada vez mais para ganhar pontos", mas não ganhou: "nos decepcionamos em todas". E creio hoje que era mesmo para se decepcionar.

Quando revia os vídeos e analisava os dados que tinha em minhas mãos - já afastada da parte prática da pesquisa - , me dei conta de algumas questões que estavam presentes desde sempre nos textos daqueles alunos que sofreram e que me tiraram o chão inicialmente em minha estratégia. AutorB54 expressou claramente o esforço deles: "se esforçou cada vez", sem que houvesse reconhecimento algum. Eu me dei conta, então, de que simplesmente não havia previsto uma pontuação para o processo em si, apenas para a finalização do processo. O que estava fazendo de diferente das avaliações propostas na escola que temos hoje? O fato de ser uma atividade em grupo com uma proposta lúdica não valeu em partes para esses alunos quando eu não soube valorizar o empenho, o esforço de cada um como membro de uma equipe e do grupo como um todo. Não soube pontuar o esforço dispendido - que eu mesma já mencionei anteriormente e critiquei a escola por não considerá-la em seu processo avaliativo. AutorB54 mostrou, na verdade, que eu não soube enxergar nem valorizar, de fato, a construção coletiva. Principalmente em se tratando de uma atividade que se propunha ser lúdica, o que pressupõe naturalmente valorizar a ação, o momento que se vivenciava, e não apenas o resultado. Eu pensava que estava inovando com uma estratégia lúdica, mas reforcei a competição explícita, já tão presente, principalmente na instituição onde a pesquisa se realizava. Além disso, eu propunha uma aprendizagem colaborativa, por meio das relações em grupo, mas não soube atuar para ajudar a promover a confiança entre os membros. Não sabendo valorizar visivelmente suas ações individuais ao longo do processo, eu alimentava a richa entre eles, e não o respeito. Morgon (2013) fala sobre ambiente seguro, confiança e valorização da partes, mas que percebo que eu não soube desenvolver a contento. Enfim, a decepção, que pode ser traduzida em frustração, foi o que, ao menos, esses quatro alunos viveram.

Em um primeiro momento fiquei assustada com o que estava lendo e a única ideia que tive na hora foi lhes proporcionar uma nova chance de crescer na disputa, pensando que isso poderia elevar-lhes a autoestima e solucionar a questão. Afinal, AutorB54 também destacou algo naturalmente importante e 
existente nos jogos e que, por mais que houvesse em minha proposta com o feedback nas reescrituras, não existia nas atividades em sala de aula. Ela disse: "Acho que deveria ter segundas rodadas para dar uma segunda chance para guildas quando ouver dois tempos."

Hoje me pergunto: de que adiantava tanto feedback como eu me propus a fazer, sem que houvesse, de fato, situações, nas atividades presenciais (momento em que o professor está ali para orientar e ajudar na construção da aprendizagem), para refazer o caminho errado tendo a segunda chance para tentar acertar? Isso ocorria sempre nas redações e nos trabalhos em que eles podiam levar para casa e refazer, mas nas atividades e interações em sala, as dinâmicas eram pontuais, para serem realizadas em uma ou duas aulas, sem tempo (fator da nossa escola de hoje me engessando) para repetir até todos atingirem o objetivo.

Sem saber ainda muito como fazer, percebi que nessa proposta de texto de opinião, os quatro membros dessa guilda haviam escrito mais de uma página do caderno de opinião cada um. E comparando com os demais alunos, detectei que muitos deles apenas cumpriram a tarefa de opinar, mas de forma rápida e sem mais detalhes. Então, pensei em criar uma estratégia na qual pudesse beneficiálos, como se fossem "vidas extras" em um jogo de videogame. Mas a forma para corrigir tal falha, num primeiro momento, foi valorizar o que não deveria ser valorizado: a pontuação para atualização do ranqueamento, por meio do enaltecimento de seus textos.Ao promover isso na turma, foi nítida a mudança de fisionomia deles quando receberam pontos por terem produzido textos bem detalhados e grandes; e mais nítida ainda para mim foi a troca de olhares entre os alunos na sala de aula. Realmente havia algo entre eles que eu não tinha controle. Havia uma comunicação, uma interação e uma disputa que ia muito além do que estava explícito. Ficou mais claro ainda, naquele momento, que as relações de grupo, de colegas, de turma, isto é, do coletivo, são muito mais sérias e intrincadas do que conseguimos enxergar nos tempos engessados, limitados e limitantes, que temos em sala de aula com eles. E eu, professora que propunha uma nova estratégia, não tinha levado em conta as consequências de minhas escolhas. Está aí mais um elemento que se soma aos anteriormente apontados e que estão diretamente ligados à necessidade de uma formação docente bem mais consistente sobretudo em relação ao conhecimento do comportamento humano. 
Talvez isso tenha sido um dos fatores que me influenciaram a não atribuir tanto valor à pontuação dos alunos nas atividades seguintes, até que, no quarto bimestre, essa "medição" com o fim de se ter um campeão foi se desfazendo e acabou esquecido. Apesar disso, havia assumido um compromisso no início com eles e precisava ir até o fim do terceiro bimestre. Por isso, fechamos o período com a organização dos pontos e a premiação das guildas vencedoras (como já apresentei, essa atividade ocorreu no início do quarto bimestre).

Apesar desse meu tropeço, a opção por uma estratégia lúdica em que se privilegia as relações de coleguismo me pareceram na época e ainda hoje, com a análise de toda a experiência, algo bastante positivo. Creio que, apenas a opção por um trabalho em prol da coletividade, buscando uma construção social mais igualitária, mais livre, parece capaz de embargar "a produção de subjetividades fechadas (...) e isto se faz proporcionando situações em sala de aula em que as características do jogo estejam presentes”. (FORTUNA, 2000, p. 7)

Dessa experiência, pude entender a necessidade de, em minha prática docente, eu ter alguma formação mais específica que me permitisse uma compreensão maior de como se dá a construção das identidades, coisa que não é muito explorada nas licenciaturas. Afinal, é preciso que o docente que se propõe a trabalhar (ludicamente) na formação de crianças e jovens consiga prever e mediar situações como essa. Além disso, cabe à escola a função de proporcionar ao estudante situações em que ele aprenda a agir em grupo, conviver com as diferenças, trabalhar em processo de colaboração e cooperação. Vasconcelos (2006, p. 70) afirma que

nos vários aspectos envolvidos na brincadeira se processam elementos que permitem sair do estado egocêntrico e centralizado em que vive, redirecionando sua linguagem para o discurso interior e sua percepção para o mundo exterior, para as propriedades existentes nos objetos e para as relações sociais, normas e regras. Isso significa que, ao brincar, a criança promove a diminuição e/ou deslocamento de seu estado egocêntrico infantil e, mediante um processo de descentralização, pode caminhar na direção do respeito ao ponto de vista das outras pessoas e, consequentemente, desenvolver relações de cooperação e reciprocidade.

É nas relações de cooperação que se inicia a tomada de consciência sobre as regras sociais. A obediência às regras é a base para a formação de valores de convivência democrática e respeito mútuo.

Talvez esse seja o verdadeiro processo educativo de que precisamos: investir na construção desse sujeito não como aluno, mas como estudante, como afirma Macedo (1999), e mudar a visão do professor para reconstruir a sua prática 
docente para uma perspectiva de aprendizagem em oposição à perspectiva do ensino.

É verdade que, da mesma forma que houve um impacto negativo que tomei conhecimento pelo relato daqueles quatro alunos, houve também um impacto extremamente positivo. Dos cinquenta e quatro alunos, posso precisar que quarenta e oito demonstraram em seus textos terem gostado, de um modo geral, do formato diferente das aulas. Os seis restantes também gostaram, mas apresentaram, em algum momento, certo incômodo ou resistência. Pensando, porém, em meu papel como educadora, não poderia manter conscientemente, da mesma forma, sem ajustes, uma proposta que gerasse sofrimento e desinteresse e uma consequente dificuldade na aprendizagem da matéria. E isso eu tomo por base o relato dos quatro alunos dessa guilda específica. Principalmente sendo esses dois sentimentos tão presentes na escola que temos hoje, como detectei nos relatos sobre a semana de provas.

Quando a estratégia de sala de aula muda da passividade/recepção para a atividade e produção constantes e coordena individual e coletivo, o registro contínuo e transparente de cada atividade realizada e a presença de um instrumento aberto/acessível que assinale como foi a atuação de cada aluno e do grupo a que pertence (de forma simples que seja, por exemplo, se fez/fizeram por inteiro determinada tarefa, se deixou/deixaram inacabado, se não fez/fizeram e/ou se entregou/entregaram com atraso) se tornam guias para a percepção da ação/participação de cada aluno e de cada grupo pelo professor e pelo(s) próprio(s) aluno(s). Isso, no entanto, não pressupõe uma pontuação que gere uma disputa por posição em ranking. Ao contrário, pode haver um empenho pessoal e do grupo para que cada um deseje superar seus limites e fazer melhor a cada nova oportunidade que tem para provar que é capaz de seguir no “jogo". Em relação ao coletivo, isso deve promover a colaboração, a troca, a cooperação, pois ajudando o colega a "correr junto" fica mais fácil atingir o objetivo almejado. Segundo Fortuna (2000, p, 9), “a aula lúdica é aquela que desafia o aluno e o professor e situa-os como sujeitos do processo pedagógico. A tensão do desejo de saber, a vontade de participar e a alegria da conquista impregnarão todos os momentos desta aula." Mas tal estratégia deve ser muito bem preparada para atingir seu objetivo positivamente, principalmente em se tratando de crianças. 


\subsection{Dificuldades que aparecem nos pequenos detalhes: só enxerga quem presta atenção}

Um ponto que, depois de toda a análise dos dados, considerei importante também comentar diz respeito às condições adversas que enfretamos no processo de ensino e aprendizagem, mas que, muitas vezes, sequer percebemos. Normalmente elencamos diversos problemas em relação ao espaço, às condições físicas do local, à inadequação ou falta de material, entre outros inúmeros elementos bastante concretos, palpáveis ou perceptíveis em nossos constantes julgamentos. Ignoramos, porém, na maioria das vezes, as condições mais subjetivas ou que não são tão aparentes aos olhos de quem não as sente "na pele". Os fatores que envolvem a formação integral de uma criança são vários e a escola geralmente ignora tais situações não tão visíveis.

Uma dessas condições tem a ver com as distâncias e as dificuldades no ir e vir no dia a dia de uma criança. Na instituição onde a pesquisa se realizou, em particular, há esse grave problema, porque a escola não é de bairro. Ela atende um público que se espalha por esta enorme cidade de trânsito congestionado e tenso. Resultado: há crianças que, desde os 10, 11 anos de idade acordam às quatro da manhã, como no relato abaixo, passam a manhã inteira no colégio e, quando precisam participar do apoio ou da recuperação, permanecem à tarde duas ou três vezes na semana (desde 2015 ficam até às 16h, duas vezes por semana, no projeto de ensino integral). Vários ainda esperam o ônibus da Divisão de Ensino que só sai às $17 \mathrm{~h}$ e leva os alunos que moram em vilas militares como em Deodoro, por exemplo.

Desculpi nã̃ te ecrito munto mas tava com o deveres para fazer e fiquei casada e acordo 4 horas da manha desculpe (AutorB18)

Então, levanto algumas perguntas para as quais ainda não tenho respostas:

- Que condições uma criança destas tem para estudar em casa e fazer as tarefas que lhe são passadas pelos professores?

- Que concentração tem uma criança destas para assistir a várias horas de aula sentada, no calor, sem conforto e, muitas vezes, sem uma boa alimentação?

- Como uma criança destas, que já apresenta lacunas e dificuldades, aprende e vence as suas limitações que são negativamente ampliadas com as condições adversas? 
Outro ponto relevante está ligado à tensão emocional criada, que os próprios alunos nomearam quando escreveram sobre a semana de provas. $\mathrm{O}$ relato, por vezes, parece dramático, sem que eles se deem conta disso.

(...) quando estou no ônibus da DE eu durmo para não esquecer as coisas, mais quando eu chego na escola eu acabo esquecendo de 2 ou 3 (...) acabo errando tudo, eu começo a ficar nervosa começo a suar como se eu foçe lutar no ringue de luta (...) $(\text { AutorA11) })^{68}$

AutorA11 dorme no ônibus "para não esquecer as coisas". Ela congela o pensamento para que eles não escapem com o vento, com a viagem de ônibus, com uma borboleta que passe diante de seus olhos e tire o seu foco e concentração. Essa criança que foi reprovada em 2014 e jubilada em 2015 não se adequa ao processo de ensino e aprendizagem a que é submetida, e a escola a perde e a "joga no mundo", em outros ringues de luta, com seu conceito equivocado de avaliação da qual ela é, sim, uma vítima. Quantas vidas mais serão descartadas de uma inclusão social por uma inadequação a um sistema falido?

Esses exemplos de situações adversas, a meu ver, só ratificam a necessidade de uma escola lúdica, uma escola que desenvolva, desperte nas crianças e adolescentes um prazer funcional em suas atividades. Como dizem Macedo, Petty \& Passos (2007, p. 18),

o espírito lúdico refere-se a uma relação da criança ou do adulto com uma tarefa, atividade ou pessoa pelo prazer funcional que despertam. A motivação é intrínseca; é desafiador fazer ou estar. Vale a pena repetir. O prazer funcional explica por que as atividades são realizadas não apenas como meios para outros fins (ler para obter informações, por exemplo), mas por si mesmas (ler pelo prazer ou desafio de ler).

O lúdico é capaz de "aguçar a inteligência. A tristeza produz estreitamento e se constitui em bloqueio para a aprendizagem". (Oliveira, 2006, p. 79) E por que ainda hoje a escola se faz triste e entediante? AutorA50 e AutorA36 traduziram, em poucas palavras, a oposição direta ao espírito lúdico de uma escola:

Eu sinto muito pouco entusiasmo para fazer as “AE's", algumas até já me deram um pouco de sono. (AutorA50)

(...) fico mais nervoso para aquelas provas que realmente não sei a matéria e ao mesmo tempo fico de "saco cheio" ao estudar essas materias pois geralmente essas são as que menos gostamos e ao mesmo tempo a que mais estudamos. (AutorA36)

\footnotetext{
${ }^{68}$ Transcrevo aqui trecho menor de passagem já apresentada na página 187.
} 
Se pudéssemos fazer uma escola que fosse, de fato, baseada em propostas lúdicas, produziríamos naquele que nela está uma plenitude de experiências e de aprendizagens, e não sono, tédio, medo, nervosismo, tensão, "brancos".

AutorB6, mais uma vez com seu relato contundente transcrito na página 203, faz uma síntese dos erros que cometemos em nossa prática, numa sala de aula. Essa é uma outra grave adversidade: a falta de preparo de professores e pessoas ligadas à Educação no que diz respeito às questões emocionais, subjetivas da formação da criança e, mais grave ainda, o nosso desconhecimento sobre como se dá a aprendizagem, como se constrói a aprendizagem, e o nosso erro sobre o que se valoriza: o produto final ou o processo.

Nesse sentido, a profissão docente ainda recai muito em amadorismo. Como afirma Macedo (2007), é preciso que o professor se profissionalize:

Valorizar a importância da prática reflexiva na escola significa, entre outras coisas, assumir que o magistério deve ser reconhecido como profissão e não apenas como simples ofício. Tal como ser médico ou engenheiro, ser professor supõe uma formação séria, complexa e difícil, mas altamente valiosa. Ensinar é mais do que uma extensão do trabalho de casa ou da mera repetição de um manual ou de um texto didático escrito por um especialista. Agora a escola se tornou para todos, isto é, tornou-se compulsória e obrigatória, cumprindo o direito de nela as crianças poderem aprender o que é significativo para suas vidas. Para bem realizar isso, temos de nos profissionalizar. A prática reflexiva é um dos recursos para isso. (2007, p. 43)

Nesse trecho, o autor junta o papel dessa minha pesquisa reflexiva, realizada em caráter de autoestudo, com a percepção de que ainda há muito o que aprender para sermos docentes de uma escola para todos, de uma escola que pretende promover uma formação integral, mas que, para isso, precisa do lúdico.

\subsection{Finalmente, o lúdico realmente vale a pena?}

Mostrei aqui, até o momento, pontos positivos e negativos da estratégia realizada. Discuti meus erros e meus acertos enquanto professora que deseja se transformar e transformar a escola. Para fechar, porém, esta discussão com a essência do que o lúdico na escola pode trazer para o aprender e para o estudante em si, encerro este capítulo com algumas falas dos autores sobre a experiência vivida, destacadas das (Auto)avaliações de final de bimestre. Enxergo aqui o que Paín (2014) apresenta e que já apontei no Capítulo 2. É necessário converter uma aprendizagem vivenciada frequentemente como obrigação em algo que interesse, 
fascine, encante, envolva, instigue, provoque, atraia, excite. E que, por conseguinte, crie o desejo de mais e mais. Porque aquele que descobre o prazer de aprender quer sempre mais:

esse bimestre não foi tão chato quamto eu, pensei que seria (...) Mas acabei quebrando a cara, esse bimestre foi demais!!! Pelomenos a materia de português né? (AutorB14, grifo meu)

O bimestre foi muito legal, as guildas tiraram todo o tedio das aulas (sem ofenças mas notas de aula ${ }^{69}$ é muito chato!) (AutorA22, grifo meu)

Achei que foi uma forma bem mais divertida e melhor de compreender a matéria. Gostei bastante. (AutorA39, grifo meu)

Positivo: o caderno que a professora deu para a gente escreve ais nossas opiniões. (AutorA11, grifo meu)

Gostei das guildas porque nos uniu mais e mesmo brincando muito nos aprendemos com essas brincadeiras. (AutorA7, grifo meu)

O que eu achei positivo foi que a professora mudou a aula, deixou ela mais interessante pra nós, fez nós nos interessarmos pela matéria. (AutorA32, grifo meu)

Eu gostei bastante, porque uma atividade em guildas evolui o companherismo a união e também pela experiência nova. (AutorB19, grifo meu)

É possível perceber o interesse, a alegria e a motivação dos alunos. Quando perguntados se tinham alguma sugestão para melhorar as aulas eles dizem querer mais horas de Português:

Dar mais um tempo de aula para Português e continuar fazendo atividades cada vez mais interessantes para incentivar os alunos que nao gostam de participar da aula a participarem. (AutorA44, grifo meu)

Só acho que temos que ter mais português. Ter mais tempo de aula na semana. (AutorB30, grifo meu)

Mais aulas de português nas semanas, mas trabalhos divertidos e mais trabalhos em grupo. (AutorB1, grifo meu)

(...) e que a aula dure mais do que é para durar. (AutorA11, grifo meu)

Um clube de português a tarde, com bastante brincadeiras envolvendo o português

de forma diferente (...) (AutorB4, grifo meu)

O que foi negativo é que (...) não temos muitas aulas de português como deveríamos ter! (...) ter mais tempos de aula de português: SEGUNDA, TERÇ, QUARTA e QUINTA. 2 tempos cada dia! (AutorB4, grifos meus )

As palavras falam por si.O aluno é "um ser do desejo, mais do que da necessidade" (OLIVEIRA, 2006 p. 86). É claro que já existem diversos estudos

${ }^{69}$ Nota de aula é o nome que se dá para apostilas ou folhas de conteúdo elaborado pelos professores e que norteiam muitas de nossas aulas no sexto ano. 
que tratam da formação integral do aluno. O problema, porém, está em sair do papel, da passagem da prática prescrita para a prática no diaadia da sala de aula nas atuações docentes, principalmente daqueles que já repetem há anos o mesmo discurso. Não existe um "manual" sobre como se trabalhar com o lúdico, como se avaliar com o lúdico nem há a necessidade de negar todo o processo de avaliação, já que ele também é importante para quantificar e comparar, em um sistema imenso como o brasileiro, a aprendizagem.

No entanto, está mais do que claro que o processo que reproduzimos há anos já se mostrou inadequado. As crianças e jovens anseiam, repito,por algo que os interesse, fascine, encante, envolva, instigue, provoque, atraia, excite na sala de aula, pois o que existe hoje já está falido, não satisfaz mais. E talvez esta seja a maior causa dos fracassos escolares: a incompatibilidade entre o que se faz e o que se deseja. 


\section{Lúdico que é lúdico marca para sempre nossas aprendizagens}

A experiência de acompanhar um trabalho no qual estive concomitantemente dentro e fora do processo significa produzir algo que traz a marca da minha singularidade, algo que somente a mim pode-se conferir a autoria. E isso é maravilhosamente gratificante. Propondo ser, e realmente o sendo, uma pesquisa-ação, o desenvolvimento singular desta tese acabou por viabilizar também o caráter de autoestudo ("self-study"), transformando-se numa narrativa descritiva de valor inestimável porque viabilizou ainda, e principalmente, a transformação do perfil docente de quem a conduziu, ou seja, eu.

Não sou mais a mesma hoje, do que antes fui; disso tenho certeza! Mas ainda me sinto num período de transição em que ora privilegio o novo paradigma docente adequado aos tempos atuais, ora recuo para as malhas confortáveis da docência sempre usada. E é desse lugar em que a minha equilibração majorante (de que Piaget nos fala) ainda dá seus primeiros passos que chego às conclusões finais.

Levanto primeiramente a relevância deste trabalho em que a prática, partindo de um escopo conceitual inicial, tomou todo o espaço da jornada e a teoria veio à tona sempre que necessária para organizar e costurar essa prática. Por ser novo para mim, muitas vezes o conhecimento dos pressupostos teóricos do autoestudo como metodologia de pesquisa veio posteriormente e ratificava a prática que eu ia tecendo ao longo das aulas.

No meio do caminho tinha uma pedra

tinha uma pedra no meio do caminho

tinha uma pedra

no meio do caminho tinha uma pedra.

Drummond era um sábio. Há muitas pedras em nossos caminhos de retinas fatigadas. Elas são várias e de tamanhos diferentes. Há as pedras-governo cujas políticas investem na aquisição de coisas, mas pouco investem na formação dos sujeitos que estão no dia a dia, na prática, na lida dentro de todo esse processo. Há as pedras-gestores das instituições que apresentam mudanças, na maioria das vezes burocráticas, criam regras e impõem normas sem olhar ou sequer também 
ouvir aqueles que estão no dia a dia, na prática, na lida dentro de todo esse processo. Há ainda as pedras-estrutura, as que enquadram a cartografia da escola, mantendo-a engessada e restritiva. Há as pedras-professores, ou seja, nós que, em nossas próprias práticas, enraizados em modelos e visões, muitas vezes, ultrapassados, não conseguimos nos conectar com o tempo em que vivemos, ou melhor, não conseguimos nos desconectar de uma visão nostálgica de um passado idealizado. Há, também, as pedras-alunos que, em parte vítimas desse paradigma instaurado e reproduzido, em parte leitores sagazes desse processo, sofrem ou se aproveitam das brechas que se criam, fechando-se às possibilidades de aprendizagens e se desconectando desse espaço nada significativo para eles.

O que propus, inicialmente em minha pesquisa, não foi a inserção e uso de jogos existentes no mercado ou criados para a escola (jogos pedagógicos), embora acredite também no potencial de ambos os tipos se bem utilizados e em duas situações os tenha usado. Descobrindo a importância das condições do lúdico em si mesmo, propus, na verdade, a inserção de elementos presentes nos jogos em meus procedimentos didáticos, porque tomei como premissa básica que jogo para ser jogo tem de ter os participantes engajados no interesse comum que o jogo os envolve.

Porque considerei que poderia estabelecer uma relação homóloga entre as condições lúdicas e as estratégias usadas no processo de ensino-aprendizagem, utilizei alguns procedimentos didáticos que proporcionavam a incorporação de elementos de jogos no contexto da sala de aula e da minha disciplina Língua Portuguesa, contexto esse que, em princípio, parecia nada ter a ver, em sua tradição, com jogos.

Nesse caso, o que fiz foi oferecer ao estudante a possibilidade de ele se tornar comprometido com o que estava aprendendo e, como tal, constantemente ativo nas aulas presenciais, porque se instaurava o interesse por aprender e, assim sendo,"fidelizava-se" a um compromisso.

Do jogo, tomei a atitude de protagonista de sua ação, nesse caso sua aprendizagem, em um processo ininterrupto de construção e superação dos desafios que a vida como um todo e a vida escolar, em particular, lhes proporciona. 
Além disso, baseando-me ainda na construção de certos jogos - em que somente e exclusivamente se houver a união dos participantes de cada grupo, alcançam-se os objetivos finais, a vitória -, trabalhei sempre com a construção de aprendizagem colaborativa, coletiva.Ademais, lancei mão, como nos jogos de percurso, de pequenos desafios por vez, para que o aluno não desanimasse em seus primeiros erros, não se vitimasse nem se acomodasse numa visão de incompetência e menos-valia. Creditei ao constante feedback e interação professora-aluno/a(s) os pontos de maior importância da estratégia lançada, na certeza de que, essa minha ação pedagógica daria forças aos alunos a vencerem suas barreiras e superarem suas próprias dificuldades.

Assim sendo, de modo bem específico, posso dizer que a estratégia realizada trouxe um grande ganho para a construção da autonomia dos alunos. Embora seus textos fossem corrigidos por mim, como fazemos no dia a dia das práticas de ensino de redação em Língua Portuguesa, os alunos perceberam logo que a correção não era um fim em si mesmo. Havia não somente chances para melhorá-los e, por consequência, elevar a nota quando era, na prática, pontuada (pensando nos parâmetros comuns à escola tradicional), mas havia também abertura para entendimento das situações expostas, com ou sem sigilo, respeito por suas opiniões e segredos, além de diálogo constante.

Em outras palavras, consegui construir com eles um vínculo de confiança. E essa confiança, a meu ver, foi o fator gerador do escrever mais e mais, com liberdade. Até mesmo porque eles entenderam que o escrever em si era muito mais importante para mim do que o escrever para serem pontuados, principalmente porque eles escreveram muitas vezes sem valor de nota. Eles acreditaram em mim.

A escrita pela escrita levava-me ao (re)conhecimento de meu aluno e ele percebia claramente essa relação e gostava disso. A escrita da escola tradicional leva à "rotulação" do aluno: esse escreve bem, esse escreve mal. Por mais que haja intenção de levá-lo a aprender, a melhorar e a tornar-se competente na modalidade escrita, com a falta de tempo e de vínculo (uma relação real de confiança no processo), o que se promove é a aproximação dos que têm bons resultados e o afastamento dos que não atingem o “ideal”. Isso destrói, por si só, o 
papel da escola que se pretende "para todos" e leva muitos ao fracasso já tão conhecido.

Em resumo, para me fazer bem clara, a liberdade de expressão promovida insistentemente para que eles se soltassem, realmente gerou a liberdade para a aprendizagem. A possibilidade de aprendizagem sem as amarras estruturais e estruturantes de uma escola tradicional, ranqueadora e excludente promoveu o que se conceitua, efetivamente, por interesse, a relação que se estabelece entre o desejo e aquilo que pode realizar esse desejo. Foi preciso eu compreender exatamente isso, ou seja, que os desejos não são espontâneos, não surgem do nada, mas aprendidos através do processo de identificação do aluno com as figuras significativas que lhe rodeiam e que sustentam o estrato histórico-social circundante do aprendiz.

No meu caso, porque ombreei com meus alunos no jogo da Língua Portuguesa, porque eles, de um modo geral, entenderam a minha proposta, a minha disposição, surgiu o interesse que, por consequência, promoveu a participação, o investimento de tempo e a atenção do aluno para a matéria que eu lecionava e para as atividades que eu propunha. Isto é, o "círculo mágico" em que o lúdico propicia a entrada, nada mais é do que a construção do ciclo do interesse gerado pela confiança. Ensinar ao aluno algo significativo para ele consiste em dar significado a ação de aprender. Aprender a aprender não pode ser aprender por aprender.

No ambiente educacional costuma-se ouvir que só se aprende o que tem sentido, o que é relevante para o aprendiz. O que é insignificante para ele não vai "entrar em sua cabeça"; pode até ser retido, numa aprendizagem mecânica, por algumas horas, somente para ser usado em uma avaliação específica, mas não vai fazer parte de sua bagagem de aprendizagens. Todos nós professores sabemos ou, de algum modo, ouvimos dizer isso. Entretanto, na prática, essa máxima fica a deriva em todo o processo de ensino e aprendizagem. Por quê?

Há receios em adotá-la, porque pode significar que, se o aluno só aprende o que faz sentido para ele, há o perigo de o professor e de a escola ficarem à mercê desse aluno. Há receios, muitas vezes, de que o aluno, se ouvido e atendido, só vai mostrar interesse por temas ou questões que não se enquadram nos parâmetros 
curriculares. E como, então, ficará o cumprimento do programa? Não fará com que o aluno reine e o professor perca o pulso da turma?

Com esses medos do novo paradigma e da possível perda do que já está estabilizado, muitos professores não se atrevem, "batem o pé" e continuam no ringue de luta, impondo do mesmo jeito os conteúdos da disciplina que lecionam e se digladiando com um aluno que, por não mostrar interesse, é julgado relaxado, vagabundo... Nada melhor do que trazer o texto "Circuito fechado" de uma guilda da Turma B como retrato dessa conjuntura:

Despertador, Facebook, chinelo, água, vaso, Facebook, Whatsapp, descarga. Leite, pão, manteiga. Escova, água, pasta, Whatsapp, água, pia. Torneira, água, chuveiro. Xampu, sabonete, creme, água, toalha. Whatsapp. Blusa, calça, sapato, boina, mochila, lanche. Foto, Whatsapp. Onibus, whatsapp, Candy Crush, Whastaspp, Candy Crush, Whatsapp. Colégio, continência, amigos, foto, whatsapp, bronca, escada, sala, carteira, conversa, whatsapp. Professora, apresentação, material, aula, celular, caderno, celular, caneta, quadro, celular, bronca, bolso, aula, caderno, sono, (...)

Mas, esse cabo de guerra pode ter um fim. E esse fim está naquilo que a própria escola ignorou desde sempre: a dimensão socioemocional presente e condição sine qua non do ato de aprender.

Não são os conteúdos (todos eles) que têm de mudar, mas o modo como eles são apresentados em sala. Para que um objeto de conhecimento, considerado relevante pela escola, se torne "aprendível" pelo aluno, ele tem de ser transformado pelo professor em relevante para o aluno. Em outras palavras, a partir dessa minha experiência prática no ensino de Língua Portuguesa, o escrever bem e de acordo com a modalidade culta da língua é considerado fundamental na aprendizagem escolar. Constitui-se, no entanto, um enorme desafio transformar essa necessidade de aprendizagem em algo relevante no diaadia para o aluno. $\mathrm{Ou}$ seja, não se conformar em considerar essa proposta como uma teoria utópica de algo inatingível dentro da visão limitada do mundo escolar, mas sim tomar a dimensão sociocultural mais ampla do ato de ensinar.

Enquanto a escola permanecer ignorando o ser humano inteiro, com todas as suas dimensões, quais sejam, cognitiva-afetiva, social-relacional (e aí eu estendo aos gestores que ignoram as dimensões também de seus professores), continuará exilando muitos do direito à cidadania. E o que se dará já está muito bem representado. 
Isso tudo parece óbvio. A grande questão é transformar o óbvio teórico numa prática escolar. O que demonstrei aqui, então, é que existe, e eu encontrei, uma possibilidade para se transformar a aprendizagem entediante, pesada, temível e devastadora de sentimentos e emoções, em algo interessante, por conseguinte, motivador. Mas não como uma fórmula mágica fechada, uma receita de bolo. Cada professor, em cada disciplina, e cada escola em seus planos didáticopedagógicos precisam desenvolver modos de transformar o obrigatório em significativo, o cansativo em interessante. Daí a urgência de pesquisas-ação, com prática de autoestudo de professores reflexivos, como esta. Somente essa reflexão intensa e extensa possibilita o entendimento dos erros e acertos do que fazemos no dia a dia da sala de aula.

Consciente disso, eu, como professora - entre impor essa aprendizagem como necessária para quem quisesse segui-la, e os que não quisessem ou não conseguissem seriam descartados no caminho; ou criando um vínculo de confiança e cumplicidade com eles para que tal aprendizagem, importante para mim (enquanto escola), se tornasse também importante e necessária para o aluno (em sua vida, em sua percepção de mundo) - fiz a minha escolha. Eu optei pela segunda hipótese e sobre ela escrevi minha tese. 


\section{Referências bibliográficas}

ALVES, R. A alegria de ensinar. São Paulo: Ars poética, 1994.

BRENELLI, R.P. O jogo como espaço para pensar: a construção de noções lógicas e aritméticas. Campinas: Papirus, 1996.

BROUGÈRE, G. Brinquedo e cultura. São Paulo: Cortez, 2004.

CASTILHO, F. Ouro, fogo \& megabytes. O legado folclórico. Belo Horizonte: Editora Gutemberg, 2013.

FLORES, M.A. Formação docente e identidade profissional: tensões e (des)continuidades. Educação, Porto Alegre, v. 38, n. 1, p. 138-146, 2015.

FORTUNA, T. R. Sala de aula é lugar de brincar? In: XAVIER, M.L.M.;DALLA ZEN, M.I.H. (Org.) Planejamento em destaque: análises menos convencionais. Porto Alegre: Mediação, 2000.

GEE, J.P. Bons videojogos + boa aprendizagem. Coletânea de Ensaios sobre videojogos, a aprendizagem e a literacia. Edições Pedagogo: Portugal, 2010.

GEERTZ, C. A interpretação das culturas. Rio de Janeiro: Editora Guanabara, 1989.

HOUAISS, A.; VILlAR, M. de S. Dicionário Houaiss da Língua Portuguesa.

Rio de Janeiro: Objetiva, 2001.

HUIZINGA, J. Homo Ludens: o jogo como elemento da cultura. São Paulo: Ed. Perspectiva, 2000.

LARROSA, J. Experiência e alteridade em Educação. Revista Reflexão e Ação, Santa Cruz do Sul, v.19, n.2, p. 4-27, 2011.

LAUAND, J. Deus ludens - O lúdico na pedagogia medieval e no pensamento de Tomás de Aquino. In: ARANTES, V.A. (Org.). Humor e alegria na educação. São Paulo: Summus, 2006.

MACEDO, L. de; PETTY, A.L.S.; PASSOS, N.C. Aprender com jogos e situações-problema. Porto Alegre: Artmed, 2007.

MACEDO, L. de. Competências e Habilidades: elementos para uma reflexão pedagógica. 1999. Texto digital. Disponível em <http://www.cefetsp.br/edu/eso/competenciashabilidades.html>. Acesso em 29/07/2015.

MACEDO, L. de. Competências na Educação.Disponível em <http://www.rededosaber.sp.gov.br>. Acesso em 29 de jul. 2015.

MACEDO, L. de. (Vídeo) Galeria de Pensadores, Canal Tim Faz Ciência, Youtube. Publicado em 10 de abr de 2014. Disponível em $\langle$ https://www.youtube.com/watch?v=TgTI5gS107c $>$. Acesso em 29/02/2016.

MAIA, M.V.C.M. (Org.). Criar e brincar: o lúdico no processo de ensino e aprendizagem. Rio de Janeiro: Wak Editora, 2014.

MAIA M.V.C.M.; ARAÚJO, S.C.G.de. "Tia cadê a outra professora?" O cuidar nos pede maestria. In: MAIA, M.V.C.M.. (Org.) Criar e brincar: o lúdico no processo de ensino e aprendizagem. Rio de Janeiro: Wak Editora, 2014.

MAIA, M.V.C.M.; COIMBRA, S. É possível que o lúdico e os procesos avaliativos caminhem juntos em uma prática pedagógica? In: MAIA, M.V.C.M. (Org.). Criar e brincar: o lúdico no processo de ensino e aprendizagem. Rio de Janeiro: Wak Editora, 2014.

MAIA, M.V.C.M.; VENEGAS, S.A. "Por que estão aprendendo Matemática ao invés de estarem jogando?": reflexões sobre o não lúdico na instituição 
educacional. In: MAIA, M.V.C.M. (Org.) Criar e brincar: o lúdico no processo de ensino e aprendizagem. Rio de Janeiro: Wak Editora, 2014.

MAMEDE-NEVES, M.A.C. A crise dos paradigmas em Educação na óptica da Psicologia. In: BRANDÃO, Z. (Org.) A crise dos paradigmas e a Educação. São Paulo: Cortez, 1999.

MAMEDE, A. Os jogos e a aprendizagem. Publicações do Curso de Especialização em Psicopedagogia Clínica e Escolar. Salvador: Escola Baiana de Medicina, 2012.

MARCONDES, M.I.G.F.; FLORES, M.A.F.F. O autoestudo e as abordagens narrativo-biográficas na formação de professores. Educação, Porto Alegre, v. 37, n. 2, p. 297-306, 2014.

MARTINS, C. Gamificação nas práticas pedagógicas: um desafio para a formação de professores em tempos de cibercultura. 2015. 112 f. Dissertação de Mestrado, Programa de Pós-Graduação em Educação da PUC-RS, Porto Alegre, 2015. Disponível em <http://hdl.handle.net/10923/7809>. Acesso em 29/02/2016.

MORGON, M.T. A necessidade da criatividade na Educação Básica: entraves e possibilidades. 2013. 126 f. Dissertação de Mestrado, Faculdade de Educação, Universidade Federal do Rio de Janeiro, Rio de Janeiro, 2013. Disponível em <http://www.educacao.ufrj.br/dmarianatesch.pdf >. Acesso em 29/02/2016.

NEGRINE, A. Ludicidade como ciência. In: SANTOS, S.M.P. dos (Org.) A ludicidade como ciência. Petrópolis: Vozes, 2001.

OLIVEIRA, M.L. de. Escola não é lugar de brincar? In: ARANTES, V.A. (Org.). Humor e alegria na educação. São Paulo: Summus, 2006.

OLIVEIRA, F.N. de; BAZON, F.V.M. (Org.). (Re)significando o lúdico: jogar e brincar como espaço de reflexão. Londrina: EDUEL, 2009.

PAÍN, S. Prefácio. In: MAIA, M.V.C.M. (Org.). Criar e brincar: o lúdico no processo de ensino e aprendizagem. Rio de Janeiro: Wak Editora, 2014.

PAÍN, S. Subjetividade e objetividade: relação entre desejo e conhecimento. Petrópolis: Vozes, 2009.

PAÍN, S. A importância da teoria na arte de ensinar. In: GROSSI, E. P. (Org.). Por que ainda há quem não aprende: a teoria. Petrópolis: Vozes, 2003.

PIAGET, J. Psicologia e Pedagogia. Rio de Janeiro: Ed. Forense Universitária Ltda., 1976.

PIAGET, J. A formação do símbolo na criança - imitação, jogo e sonho, imagem e representação. Rio de Janeiro: Zahar Editores, 1978.

PIAGET, J. Para onde vai a educação? Rio de Janeiro: José Olympio, 1988.

RIBEIRO, K.A. A Educação Física escolar e o lúdico no Colégio Militar: uma leitura fenomenológica. 2011, 110f. Dissertação de Mestrado. Programa de PósGraduação em Educação, Universidade Federal de Mato Grosso do Sul, Campo Grande, 2011.

SALEN, K.; ZIMMERMAN, E. Regras do jogo: fundamentos do design de jogos, principais conceitos. São Paulo: Blucher, 2012.

SANTIN, S. Educação física: da alegria do lúdico à opressão do rendimento. Porto Alegre: EST Ed. 2001.

SANTOS, S.M.P. dos (Org.) A ludicidade como ciência. Petrópolis: Vozes, 2001.

SANTOS, S.M.P. dos (Org.) O lúdico na formação do educador. Petrópolis: Vozes, 2011. 
SANTOS, S.M.P.; CRUZ, D.R.M. O lúdico na formação do educador. In: SANTOS, S.M.P. dos (Org.) O lúdico na formação do educador. Petrópolis: Vozes, 2011.

VASCONCELOS, M.S. Ousar brincar. In: ARANTES, V.A. (Org.). Humor e alegria na educação. São Paulo: Summus, 2006.

WINNICOTT, D. W. Tudo começa em casa. São Paulo: Martins Fontes, 1999.

WINNICOTT, D. W. A capacidade para estar-só. In:WINNICOTT, D. W. O ambiente e os processos de maturação. Porto Alegre: Artes Médicas, 1998.

WINNICOTT, D. W. O brincar e a realidade. Rio de Janeiro: Imago Ed. Ltda., 1975. 


\title{
10. Anexos
}

\subsection{Permissão para o desenvolvimento da pesquisa no CMRJ}

\author{
AUTORIZAÇÃO
}

Autorizo a professora Tatiane Marques de Oliveira Martins a desenvolver a pesquisa GAMIFICAÇÃo: UMA NOVA POSSIBILIDAdE PARA UMA APRENDIZAGEM AUTORAL? nesta instituição, durante o segundo semestre de 2014, nas turmas 605 e 606, do $6^{\circ}$ ano do Ensino Fundamental.

Fica acordado que a professora desenvolverá sua pesquisa de acordo com as normas do CMRJ e seguindo as condutas éticas de pesquisa. Ela se dispõe, também, a devolver ao colégio as descobertas de suas práticas, assim como as experiências que puderem ser reproduzidas pelo corpo docente.
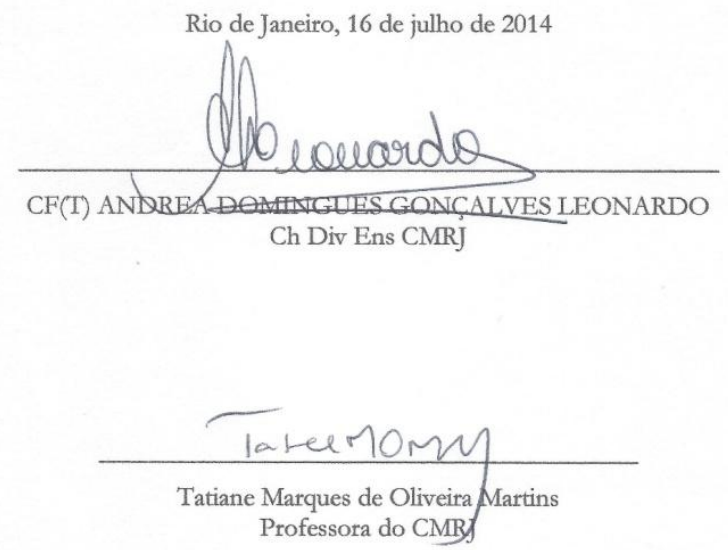


\subsection{Questionário sobre as práticas de estudo dos alunos}

Colégio Militar do Rio de Janeiro - Questionário sobre as práticas de estudo

Nome: NR:

Turma:

Data: $/ 2014$

Caro(a) aluno(a),

Sua participação nesta pesquisa é muito importante para eu poder aprimorar meu trabalho junto a você. Responda às perguntas abaixo com bastante carinho e atenção.

1. Sobre 0 ato de estudar. Eu estudo em casa...
a. ( ) todos os dias depois das aulas.
c. ( ) nos finais de semana.
b. ( ) só quando preciso.
d. ( ) Não tenho costume de estudar em casa.

2. Sobre as disciplinas escolares. Coloque $A$ (adoro), G (gosto um pouco) ou $D$ (detesto) para as disciplinas listadas abaixo
a. ( ) Língua Portuguesa
b. ( ) Matemática
e. ( ) Geografia
c. ( ) Ciências
f. ( ) Artes
d. ( ) História
g. ( ) Inglês
h. ( ) Educação Física

3. Sobre os deveres de casa. Eu faço os deveres de casa...
a. ( ) sempre que há.
b. ( ) apenas das matérias de que gosto.
d. ( ) Não tenho costume de fazer dever de casa.
c. ( ) apenas das matérias que tenho dificuldade.
e. ( ) Faço o que dá tempo.

4. Ainda sobre os deveres de casa. Na hora de fazer os deveres de casa... (Você poderá marcar mais de uma opção.)
a. ( ) sinto sono ou preguiça.
d. ( ) sento em um lugar próprio para estudar e aprender.
b. ( ) sempre me distraio com outras coisas.
e. ( ) fico feliz porque estou aprendendo.

c. ( ) preciso da ajuda de um adulto.

\section{Sobre livros e leituras. Eu}
a. ( ) adoro ler e leio vários livros todos os anos.
b. ( ) só leio os livros por obrigação escolar.
d. ( ) não gosto de ler, mas leio algumas partes dos livros
c. ( ) odeio ler. que a escola adota
e. ( ) não tenho o costume de ler.

6. Sobre as avaliações. Quando o professor marca uma avaliação para a semana seguinte, eu...
a. ( ) começo a estudar logo a matéria.
d. ( ) fico com medo porque não sei como estudar.
b. ( ) deixo para estudar apenas na véspera.
e. ( ) procuro a matéria com os amigos, porque
c. ( ) nem ligo porque nunca estudo antes dos testes. não tenho nada anotado.

7. Ainda sobre as avaliações. As avaliações escolares...
a. ( ) são sempre um tormento em minha vida.
d. ( ) me mostram que sou inteligente.
b. ( ) não são nenhum problema para mim.
e. ( ) fazem que eu me sinta burro.

c. ( ) deixam meus pais nervosos e mais exigentes

8. Sobre produção textual. Eu...
a. ( ) gosto muito de escrever no meu dia a dia.
b. ( ) não gosto de escrever.
d. ( ) acho que tenho muita facilidade para escrever.
e. ( ) acho que tenho muita dificuldade para escrever.

c. ( ) só escrevo por obrigação na escola. 
9. O que VOCÊ acha sobre as produções textuais que você faz na escola? Responda a partir dos itens que seguem:
a) A quantidade de redações produzidas por bimestre:
( ) é pouco ( ) é muito ( ) é o número certo.
b) Você aproveita o feedback que o professor dá para sua aprendizagem:
( ) sim ( ) pouco ( ) não entendo as correções.
c) O meu empenho/interesse nas produções textuais
( ) é grande ( ) é médio ( ) é baixo.

10. Sobre a escola. Eu...
a. ( ) gosto de ir à escola.
d. ( ) acho a escola uma perda de tempo.
b. ( ) não gosto de ir à escola.
c. ( ) só gosto de ir à escola por causa dos amigos.
e. ( ) não gosto da escola, mas sei que é importante.

11. Sobre o CMRJ. Eu estudo no CMRJ porque (Aqui você poderá, se quiser, escolher mais de uma opção.)
a. ( ) era o sonho da minha vida.
b. ( ) é o sonho da vida dos meus pais.
d. ( ) eu tenho direito já que sou filho de militar.
c. ( ) meus pais me obrigaram.
e. ( ) quero seguir carreira militar.
12. O que VOCÊ espera da escola para a sua vida?

13. O que VOCÊ acha que a escola tem de bom? E de ruim? BOM:

RUIM:

14. Você acha que é possível aprender Português, Matemática, História, Geografia, Ciências, Inglês e Artes através de jogos? Por quê?

15. Você conhece algum jogo que utilize conteúdos aprendidos na escola? Qual(is)?

16. VOCÊ já usou algum aplicativo de celular que seja útil na vida escolar? Qual?

17. A partir de agora, vamos usar um Portal Educacional na internet para passar deveres de casa, produzir atividades e aplicar avaliações. O que VOCÊ acha disso?
a. ( ) Acho que vai ser mais legal.
d. ( ) Poder usar o computador é sempre mais divertido.
b. ( ) Vai me dar mais trabalho.
e. ( ) Não tenho opinião ainda

c. ( ) Para mim não faz diferença. 
10.3. Ficha autoavaliativa do $3^{\circ}$. Bimestre

(AUTO)AVALIAÇÃO GUIADA

Aluno NR

Turma

Guilda

\begin{tabular}{|c|c|c|}
\hline & SIM & NÃO \\
\hline 1. Você fez o Poema Visual? & & \\
\hline 2. Você fez o Poema com palavras rimadas? & & \\
\hline 3. Você criou uma capa para seu Caderno de Opinião? & & \\
\hline 4. Você escreveu a sua opinião sobre a cor favorita? & & \\
\hline 5. Você participou da construção coletiva da opinião sobre a cor favorita? & & \\
\hline 6. Seu grupo fez corretamente a apresentação em papel colorido do trabalho sobre a cor favorita? & & \\
\hline 7. Você passou a limpo em seu caderno o "Mapa Brasilis" que sua guilda decifrou na cartolina? & & \\
\hline 8. Você pesquisou lendas raras em sua casa? & & \\
\hline 9. Você levou para a aula ao menos uma lenda rara? & & \\
\hline 10. Você reescreveu no C. de Opinião o texto sobre as aulas da semana, após a correção com códigos? & & \\
\hline 11. Você fez o trabalho sobre os dados bibliográficos do livro Ouro, fogo e megabytes? & & \\
\hline 12. Você entregou no prazo correto a ficha com os dados bibliográficos do livro? & & \\
\hline 13. Você fez o texto de opinião sobre a palestra do Felipe Castilho? & & \\
\hline 14. Você entregou no prazo correto o texto sobre a palestra do Felipe Castilho? & & \\
\hline 15. Você fez a reescritura do texto sobre a palestra, após as minhas indicações de correção? & & \\
\hline 16. Você fez o trabalho de caracterizar os personagens do livro com adjetivos (fato e opinião)? & & \\
\hline 17. Você entregou o trabalho dos personagens do livro no papel correto e com boa apresentação? & & \\
\hline 18. Você participou ativamente de todas as missões passadas para a sua guilda? & & \\
\hline 19. Você agiu com ética e respeito em todas as missões e tarefas? & & \\
\hline $\begin{array}{l}\text { 20. Você se preocupou em ajudar a sua guilda cumprindo as missões coletivas e individuais em todas as } \\
\text { dinâmicas, sem se distrair ou brincar com outras coisas durante as atividades? }\end{array}$ & & \\
\hline 21. Você acha que seus parceiros de guilda trabalharam menos do que você?? & & \\
\hline & SIM & NÃO \\
\hline TOTAL & & \\
\hline $\begin{array}{l}\text { Você acha que aprendeu os conteúdos do bimestre: poemas, texto opinativo, lendas e mitos } \\
\text { brasileiros, substantivo e adjetivo através dessas aulas em formato diferente? }\end{array}$ & & \\
\hline
\end{tabular}

Escreva a sua opinião sobre como foi este bimestre para você com relação às aulas de Língua Portuguesa. Apresente o que você achou de positivo e o que houve de negativo nas aulas, atividades etc.

Você tem alguma(s) sugestão(ões) para melhorar as nossas aulas? Aponte e, se possível, explique-a(s) 
10.4. Ficha autoavaliativa do $4 \stackrel{\circ}{\circ}$. Bimestre

(AUTO)AVALIAÇÃO GUIADA

Aluno NR

Turma

Guilda

\begin{tabular}{|l|l|l}
\hline & SIM & NÃO \\
\hline 1. Você escreveu no Caderno de Opinião a sua opinião sobre a Semana de AEs? & & \\
\hline 2. Você fez com capricho o exercício em folha a partir do texto do Boitatá? & & \\
\hline 3. Você corrigiu com atenção e conversou com seu colega sobre os erros dele no exercício do Boitatá? & & \\
\hline 4. Você fez em casa o estudo dirigido sobre Artigo, com base nos exercícios do livro didático? & & \\
\hline 5. Você aproveitou o estudo dirigido sobre Artigo para estudar o conteúdo presente no livro didático? & & \\
\hline 6. Você participou de fato da construção da HQ em grupo sobre o texto de humor da p.61 do livro? & \\
\hline 7. Seu grupo fez corretamente a apresentação da HQ criada a partir da historinha da p. 61 do livro? & \\
\hline 8. Você produziu o texto de opinião sobre a premiação das guildas do 3o bimestre e as novas guildas? & \\
\hline 9. Você entregou no prazo o texto de opinião sobre a premiação das guildas e as novas guildas? & \\
\hline 10. Você reescreveu o texto de opinião corrigido? & \\
\hline 11. Você criou a sua "Roleta Folclórica" com base nas regras estipuladas? & \\
\hline 12. Você entregou no prazo correto a sua "Roleta Folclórica"? & \\
\hline 13. Você construiu a HQ a partir do seu capítulo do livro Prata, terra e lua cheia ou Ouro, fogo e megabytes? & \\
\hline 14. Você entregou no prazo estipulado a sua HQ? & \\
\hline 15. Você produziu o texto de opinião sobre as despedidas dos colegas que vão partir e os que vão ficar? & \\
\hline 16. Você entregou no prazo o texto de opinião sobre as despedidas? & \\
\hline 17. Você construiu em sala o texto sobre as memórias do ano letivo (os quatro bimestres)? & \\
\hline 18. Você completou a escrita dos quatro bimestres e buscou em sua memória as lembranças do ano & \\
\hline 19. Você acessou o material disponível no Portal Educandus sobre Artigo e o estudou? & \\
\hline 20. Você já terminou de ler o livro Prata, terra e lua cheia, de Felipe Castilho? & \\
\hline \\
\hline
\end{tabular}

Escreva a sua opinião sobre como foi este bimestre para você com relação às aulas de Língua Portuguesa. Apresente o que você achou de positivo e o que houve de negativo nas aulas, atividades etc.

Você acha que aprendeu os conteúdos do bimestre: HQs, texto opinativo, onomatopeias, interjeições, artigos através dessas aulas em formato diferente e com os estudos dirigidos e trabalhos/avaliações passados para casa? Explique. 


\subsection{Ficha autoavaliativa sobre a produção de teatro de fantoches em grupo}

\section{(AUTO)AVALIAČ̃O GUIADA}

Aluno

NR

Turma

Guilda

Sobre a escolha da lenda para a criação do teatro de fantoches.

( ) Eu escolhi a lenda.

( ) Um colega escolheu a lenda.

( ) Alguns membros da guilda participaram da escolha.

( ) Todos da guilda participaram da escolha da lenda.

( ) Outro. O quê?

Sobre a produção dos fantoches.

( ) Eu fiz o meu fantoche.

( ) Eu fiz todos os fantoches.

( ) Um colega fez todos os fantoches.

( ) Cada membro ficou responsável por uma parte do trabalho e cumpriu o combinado.

( ) Outro. $O$ quê?

Sobre a produção do trabalho.

( ) Eu fiz todo o trabalho sozinho(a).

( ) Um(a) colega fez todo o trabalho pelo grupo.

( ) Cada membro se responsabilizou por uma parte e cumpriu.

( ) Houve gente que deixou "furo" porque não fez o combinado.

( ) Outro. O quê?

Sobre a minha atitude em relação ao trabalho.

( ) Eu tomei a frente e decidi fazer tudo já que ninguém se interessava.

( ) Eu motivei meus colegas, dividi as tarefas e combinei com cada um o que deveríamos fazer.

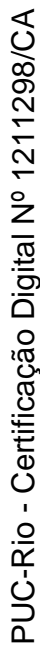

( ) Eu e meus colegas combinamos tudo juntos e fizemos tudo juntos, mesmo que cada um estivesse em sua casa.

( ) Eu não fiz nada porque não tive interesse.

( ) Eu não fiz nada porque meus colegas não me disseram o que era para fazer.

( ) Eu não perguntei aos meus colegas o que era para fazer, então não fiz nada.

( ) Outro. O quê?

Sobre os trabalhos apresentados (não marque a sua guilda). Eu gostei mais da apresentação da
( ) Guilda 1,
( ) Guilda 2,
( ) Guilda 3,
( ) Guilda 4,
( ) Guilda 5,

porque 


\subsection{Código para correção de redação}

\section{Código de correção}

Ap Apresentação (Melhorar a apresentação significa ter cuidado com a folha de redação, limpeza, a escolha da caneta, para uma boa legibilidade, espaçamento entre título e texto...)

M Margens (Corrigir o uso que você faz do espaço da folha de redação.)

MP $\quad$ Margem de Parágrafo

L L Letra ininteligível (É preciso melhor a letra para que o leitor entenda o que você escreve.)

C Concordância verbal e nominal

FV Flexão Verbal (O verbo utilizado não está corretamente flexionado.)

? Não é possível entender o que você disse.

0 Ortografia (Pesquisar a grafia correta da palavra.)

A Acentuação (Corrigir ou acentuar a palavra.)

P $\quad$ Pontuação (Verificar ausência ou erro do sinal de pontuação.)

Cs Coesão (uso de conectivos, como mas, porém, portanto, por isso, quando, então etc. e não apenas e... e... ou aí... aí etc.)

R Repetição de palavra ou expressão em parte ou ao longo do texto.

Mm Letras Maiúsculas e Minúsculas

S Separação de sílabas (É necessário separar ou corrigir a translineação feita.)

V Vocabulário Inadequado (Gíria, coloquialismos, palavras de baixo calão, uso de uma variedade inadequada à situação.)

T Título (ausência de título ou título inadequado)

\begin{tabular}{|c|c|c|c|c|}
\hline FATOS OBSERVADOS & 2 & 1,5 & 1,0 & 0,5 \\
\hline $\begin{array}{l}\text { Apresentação: letra legível e bem apresentada; folha limpa e sem } \\
\text { amassados; uso de margens de parágrafo e disposição do texto na folha. }\end{array}$ & о́тімO & BOM & $\begin{array}{l}\text { PRECISA } \\
\text { MELHORAR }\end{array}$ & CUIDADO! \\
\hline $\begin{array}{l}\text { Desenvolvimento: frases, ideias apresentadas com começo, meio e fim, } \\
\text { sem repetições excessivas e sem fugas à linha de raciocínio. }\end{array}$ & ÓTIMO & BOM & $\begin{array}{l}\text { PRECISA } \\
\text { MELHORAR }\end{array}$ & CUIDADO! \\
\hline $\begin{array}{l}\text { Escrita: uso correto de letras maiúsculas (início de frases e nomes } \\
\text { próprios); da grafia das palavras, das regras de acentuação e da } \\
\text { translineação. }\end{array}$ & ÓTIMO & BOM & $\begin{array}{l}\text { PRECISA } \\
\text { MELHORAR }\end{array}$ & CUIDADO! \\
\hline $\begin{array}{l}\text { Coesão: uso de pontuação e conectivos adequados à sua idade e } \\
\text { formação (mas, porém, portanto, por isso, quando, então etc.) e não } \\
\text { apenas e... e... ou aí... aí etc. }\end{array}$ & ÓTIMO & BOM & $\begin{array}{l}\text { PRECISA } \\
\text { MELHORAR }\end{array}$ & CUIDADO! \\
\hline $\begin{array}{l}\text { Expressão de opinião: exposição de opinião e uso de adjetivos para } \\
\text { caracterizar adequadamente o que está falando. }\end{array}$ & ÓTIMO & BOM & $\begin{array}{l}\text { PRECISA } \\
\text { MELHORAR }\end{array}$ & CUIDADO! \\
\hline
\end{tabular}




\subsection{Trecho do livro Ouro, fogo e megabytes}

Trecho do livro Ouro, fogo \& megabytes, utilizado em atividade de produção de HQ, descrita no item 34, quadro 7 do quarto bimestre.

Kraus, vestido como uma espécie de versão masculina de Lara Croft com calças de trekking, agarrou o cinto com as facas e continuou sorrindo para os reféns. Como se quisesse aplausos após o anúncio feito por Wagner Rios, que se divertia excentricamente com aquela situação constrangedora.

- Você não está esperando uma salva de palmas, né, seu escroto?

Era Chris, pronunciando-se lá no meio dos reféns comportadamente sentados, que agora também incluíam os ciganos Ghouls. Rios, Krauss e o lobisomem-Antonsson voltaram os olhos para o rapaz. A besta grunhiu, talvez reconhecendo a fera interior no rapaz. Krauss caminhou de peito estufado até mais próximo do grupo sentado, e o encarou.

- E quem é este monte de ossos petulante? - perguntou para Rios, mas sem tirar os olhos de Chris.

- Ah! - Rios gargalhou. Tudo parecia divertido para ele. - Eu recomendo um cuidado extra com este rapaz, ele...

- Meu nome é Chris. E eu não preciso que nenhum magnata fale por mim, obrigado. - Em seguida, dirigiu seu olhar amarelado para Bruno e acrescentou, mais seco que uma lixa: - E seu programa é um lixo.

Foi um chute bem rápido, assim como toda a confusão que veio a seguir. $O$ coturno de Krauss atingiu o rosto de Chris em cheio, e no outro segundo Elis chutava a parte de trás do joelho do agressor, levando-o ao chão também. Antonsson saltou em direção à garota, mas Otto, da ResEx, se levantou e deu um impressionante jogo de corpo no monstro, que se desequilibrou e cambaleou para longe. (Castilho, 2013, p. 121) 